\title{
ENZIMAS EM BIOCATÁLISE (Esterificação de aminas, adição de Michael, clonagem e expressão de álcool desidrogenase)
}

Yara Jaqueline Kerber Araujo

Instituto de Guímica de São Carlos

Universidade de São Paulo 



\title{
ENZIMAS EM BIOCATÁLISE (Esterificação de aminas, adição de Michael, clonagem e expressão de álcool desidrogenase)
}

Yara Jaqueline Kerber Araujo

Orientador: Prof. Dr. André Luiz Meleiro Porto

Tese apresentada ao Instituto de Química de São Carlos (IQSC-USP) como parte dos requisitos para obtenção do título de Doutor em Ciências, com habilitação em Química Orgânica

\author{
São Carlos - SP \\ Janeiro/2013
}

${ }^{1}$ Trabalho realizado com auxílio financeiro do CNPq (proc. 141412/2009-7). 

Dedico este trabalho ao meu irmão Luciano, que não teve tempo para ouvir o quanto eu o amo, pelo seu amor e rigidez de pai que me tornaram quem sou hoje. Descanse que em breve nos veremos lá no céu, Até breve! 


\section{Agradecimentos}

- A Deus por me sustentar em pé a cada dia.

- Ao meu esposo Erick pelo amor, pela paciência e pricipalmente pela parceria ilimitada.

- À minha mãe pelo amor sem fim e as horas de terapia by fone.

- Ao meu irmão e pai Luciano pelo cuidado e apoio silencioso, mas presente. Saudades...

- Ao meu irmão Juliano pelo carinho e as ligações impróprias.

- A toda minha família que de algum modo sempre está ao meu lado.

- Ao Professor Dr. André L. M. Porto, que apesar das divergências me proporcionou um grande crescimento profissional.

- À minha chefinha Cidinha que me dá forças para enfrentar qualquer coisa e me apoia com suas orações.

- Ao meu colega Reinaldo pelos infra-vermelhos, a parceria no trabalho e as horas de conversa.

- Aos meus colegas de laboratório, Lenilson, Mariana, Julieta, Ana Maria, Sandra, Natália, Irlon, Alex e Isac (fiote).

- Aos meus colegas do laboratório da Profa. Dra. Fernanda Canduri que me adotaram como um dos seus, Nathália, Cintia, Nikolas, Juliana e Kelly.

- À Camila Thomas por ter paciência e me ensinar a arte da biologia molecular. 
- A Profa. Fernanda Canduri pela co-orientação, amizade e confiança que me proporcionou um novo rumo na vida científica.

- Aos meus sogros que prometeram uma festa para a primeira Doutora da família.

- A todos os amigos que de tantos fica dificil colocar os nomes, mas que de suas maneiras especiais me apoiaram com as conversas, sorrisos, olhares e companheirismo durante esses 4 anos.

- Aos técnicos do CAQI (Central de Análises Químicas Instrumentais)- André (IV) e Silvana (RMN).

- Aos técnicos, do Grupo de Guímica Orgânica e Biocatálise, Marília e João Pedro.

- A Silvia, Andréia e Gustavo da secretaria de Pós-Graduação do Instituo de Guímica de São Carlos.

- Ao Instituto de Guímica de São Carlos/USP, pelo apoio institucional.

- Ao CNPq pela bolsa de doutorado.

- À FAPESP e ao CNPq pelo financiamento dos projetos.

E a todos que de alguma forma contribuíram para o sucesso deste trabalho. Muito obrigada!!! 


\section{Resumo}

As lipases têm um papel importante no desenvolvimento da biotecnologia e são empregadas na química orgânica como biocatalisadores com alta regio- quimio- e enantiosseletividade. Além de permitir sínteses mais sustentáveis e que estão em concordância com os princípios da Guímica Verde. A resolução enzimática de aminas racêmicas tem se mostrado uma maneira eficiente de obter aminas enantiomericamente puras, que podem ser empregadas na síntese assimétrica de fármacos e agroquímicos. Neste trabalho a resolução enzimática de 4 aminas primárias sendo elas 2-amino-heptano 1, 2-metil-cicloexil amina 3, 1-metil-3-fenilpropilamina 2, 1,2,3,4-tetra-hidro1-naftilamina 4, foram estudadas obtendo-se resultados relevantes. Para a 2-amino-heptano $\mathbf{1}$ resultados semelhantes aos da literatura foram obtidos com uma redução de 2,4 vezes no tempo reacional quando a resolução cinética foi em hexano na presença de CAL-B e acetato de etila como acilante obteve-se uma conversão na $(R)-N$-(1-metil-hexil)acetamida 4 de $42 \%$ e um excesso enantiomérico de $88 \%$ (tempo $=7 \mathrm{~h})$. Observaram-se também os efeitos da concentração de lipase no meio reacional, da temperatura e de diferentes solventes frente a 11 lipases. Os primeiros estudos de resolução cinética enzimática com a 2-metilcicloexil-amina 3 são apresentados neste trabalho com conversões de até $98 \%$ porém sem excesso enantiomérico. Uma outra característica das lipases é a capacidade de catalisar reações diferentes da sua função natural (promiscuidade), o que permite que elas catalisem reações de adição de Michael, além de suas reações normais que são a hidrólise e esterificação. A adição de Michael catalisada por lipases entre as 4 aminas primárias já citadas e acrilonitrila foi estudada com e sem a influência da irradiação micro-ondas, demonstrando a maior estabilidade de lipases imobilizadas sob irradiação micro-ondas. Os adutos de Michael obtidos (3-[(1-metil-hexil)amino]propanonitrila 9, 3-[(1-metil-3-fenilpropil)amino]propanonitrila 10,3-[(2-metil cicloexil)amino]propanonitrila 11 
e 3-(1,2,3,4-tetra-hidronaftaleno-1-amino)propanonitrila 12) foram sintetizados pela primeira vez com a metodologia onde foi utilizada a água, acrilonitrila e irradiação micro-ondas e os adutos 9, 10 e 11 não são descritos na literatura. Outro viés do trabalho foi a clonagem e expressão da álcool desidrogenase de Bacillus subtilis que foi clonada, expressa e purificada com sucesso. $\mathrm{O}$ interesse em tal enzima deve-se a resultados obtidos na literatura onde a utilização de células íntegras de $B$. subtilis apresentou a redução de cetonas a álcoois com alta enantiosseletividade. 


\section{Abstract}

Lipases present an important role in the development of biotechnology and are employed as biocatalysts in organic chemistry with high regio-, quimioand enantioselectivity. Besides allowing more sustainable syntheses that are consistent with the principles of Green Chemistry. The enzymatic resolution of amines has been shown to be an efficient way to obtain enantiomerically pure amines, which can be used in asymmetric synthesis of pharmaceuticals and agrochemicals. In this work the enzymatic resolution of 4 primary amines them being 2-amino-heptane textbf 1, 2-methyl-cyclohexyl amine 3, 1-methyl-3-phenylpropylamine 2 1.2,3,4-tetrahydro-1-naphthylamine 4 were studied by obtaining relevant results. For the 2 -amino-heptane 1 promoted results similar to the literature and were obtained with a 2.4 times reduction of the reactional time when the kinetic resolution was in hexane in the presence of CAL-B and ethyl acetate as acylating obtained a conversion in $(R)$ $N$-(1-methyl-cyclohexyl) acetamide 4 by $42 \%$ and an enantiomeric excess of $88 \%$ (time $=7 \mathrm{~h}$ ). We studied the effects of the concentration of lipase in the reaction, temperature and solvent using 11 different lipases. The first studies of enzymatic kinetic resolution with 2-methyl-cyclohexyl- amine $\mathbf{3}$ are presented in this work with conversions up to $98 \%$ but without enantiomeric excess. The ability of lipases to catalyze reactions with different natural function (promiscuity) is an important property, which allows them to catalyze Michael addition reactions beyond their normal reactions, the hydrolysis and esterification. The Michael addition catalyzed by lipases between the four aforementioned primary amines and acrylonitrile was studied with and without the influence of microwave irradiation, demonstrating the greater stability of immobilized lipases under microwave irradiation. The Michael adducts obtained (3 - [(1-methylhexyl) amino] propanonitrile 9, 3 - [(1-methyl-3-phenylpropyl) amino] propanonitrile 10, 3 - [(2 - methyl cyclohexyl) amino] propanonitrile 11 and 3 - (1,2,3,4-tetrahydronaphthalene-1-amino) propanonitrile 12) were 
first synthesized with the method where water is used, acrylonitrile and microwave radiation, the adducts $\mathbf{9 , 1 0}$ and 11 are not described in the literature. Another investigation of this study was the cloning and expression of alcohol desidrogrenase of Bacillus subtilis which has been cloned, expressed and purified successfully. Interest in the enzyme due to results in the literature where the use of whole cells of $B$. subtilis showed the reduction of ketones with high enantioselectivity. 


\section{Lista de Figuras}

1.1 Definição de biotecnologia $\ldots \ldots \ldots \ldots \ldots \ldots$

1.2 Reações catalisadas por lipases . . . . . . . . . . . . 4

1.3 Exemplos de resolução cinética . . . . . . . . . . . . . . 5

1.4 Diagrama de energia para uma reação enantiosseletiva frente a um composto racêmico . . . . . . . . . . . . 7

1.5 Reação de esterificação do ácido ( \pm )-mandélico com (-)-mentol catalisada em meio ácido. . . . . . . . . . . . . . . . 8

1.6 Processo BASF para a obtenção de uma variedade de aminas qui-

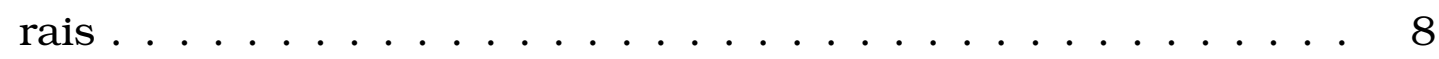

1.7 Aminas enantiomericamente puras ou enriquecidas de importância e possiveis precursores passíveis de sofrerem resolução cinética por biocatálise. . . . . . . . . . . . . . 9

1.8 Mecanismo catalítico mostrando a acilação de aminas por lipases. 10

1.9 Resolução de um ácido carboxílico catalisada por lipase de P. Ae-

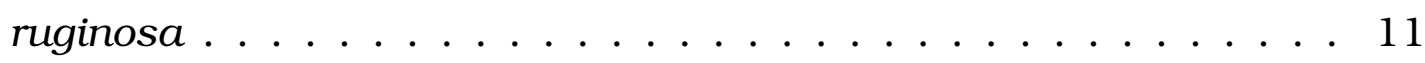

1.10 Estados catalíticos de transição . . . . . . . . . . . . . . 12

1.11 Relação entre as mãos e a quiralidade . . . . . . . . . . . . . 12

1.12 Mecanismo da reação de adição de Michael . . . . . . . . . . . 15

1.13 Exemplos de Adição de Michael catalisada por lipases . . . . . 16

1.14 Evolução da taxa de conversão com o número de re-usos do biocatalisador frente a reação de esterificação catalisada por enzima sob aquecimento clássico e irradiação MO f . . . . . . . 17

1.15Estudo comparativo da reação de adição aza-Michael entre piperidina e acrilato de metila sob várias condições utilizando ácido perclórico impregnado em sílica gel . . . . . . . . . . 18

1.16Reação de adição aza-Michael sob o efeito da irradiação MO e

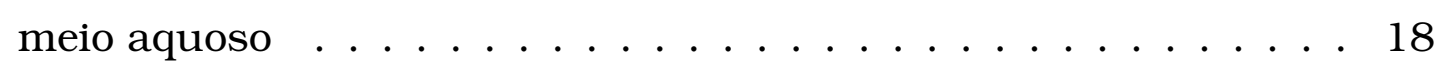


1.17 Colônias de Bacillus subtilis e micrografia do B. subtilis tipo bastonetes . . . . . . . . . . . . . . . 19

1.18Redução de iodo-acetofenonas por B. subtilis . . . . . . . . . . . 20

1.19 Reação de Suzuki entre derivados de (S)-feniletanois e ácido borô-

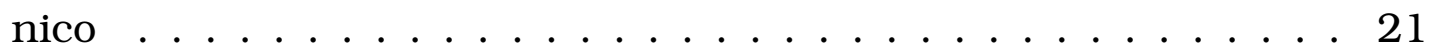

1.20 Resolução cinética do 1-metil-(1-fenil)propil hidroperóxido por $B$.

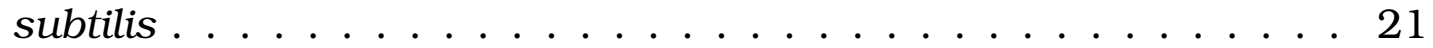

1.21 Esquema simplificado de fermentação alcóolica da glicose . . . 22

1.22 Estrutura protéica da álcool desidrogenase bacteriana de Clostridium beijerinckii e ampliação do sítio ativo com seus ligantes $\mathrm{Zn}^{2+}$ e o cofatoR NAD ${ }^{+} \ldots \ldots \ldots 22$

1.23 Sítio ativo de uma álcool desidrogenase . . . . . . . . . . . . 23

1.24 Mecanismo catalítico simplificado da álcool desidrogenase . . . 25

1.25Redução de cetonas por ADH's e sistema de regeneração de cofa-

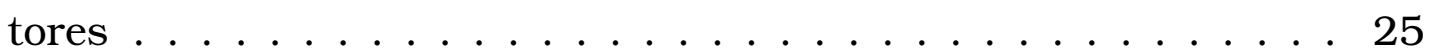

1.26 Redução assimétrica por desidrogenase em meio bifásico . . . . . 26

2.1 Resolução enzimática de aminas primárias com lipase . . . . . . . 31

2.2 Resolução enzimática de aminas primárias sob efeito da irradiação MO . . . . . . . . . . . . . . . . . . 32

2.3 Cromatograma da $N$-(1-metil-hexil)acetamida) (4) em cromatografia a gás com coluna DB-5 . . . . . . . . . . . . 33

2.4 Cromatograma da $N$-(1-metil-hexil)acetamida (4) em cromatografia a gás com coluna Chirasil - DEX CB . . . . . . . . . . . 33

2.5 Cromatograma da $N$-(2-metil-ciclo-hexil) acetamida (8) por cromatografia a gás com coluna DB-5 . . . . . . . . . . . 34

2.6 Cromatograma da $N$-(1-metil-3-fenilpropil) acetamida (6) e a amida (2) por cromatografia a gás com coluna DB-5 . . . . . . . . . 35

2.7 Cromatograma da $N$-(1-metil-3-fenilpropil) acetamida (6) por cromatografia a gás com coluna Chirasil - DEX CB . . . . . . . . 35

2.8 Cromatograma da $N$-(1,2,3,4-tetra-hidronaftaleno) acetamida (7) e da amina 3 em cromatografia a gás com coluna DB-5 . . . . . . 36

2.9 Cromatograma da $N$-(1,2,3,4-tetra-hidronaftaleno) acetamida (7) em cromatografia a gás com coluna Chirasil - DEX CB . . . . . 36

3.1 Reação de adição de Michael catalisada por lipases em agitação orbital .................... 51

3.2 Reação de adição de Michael catalisada por lipases sob irradiação

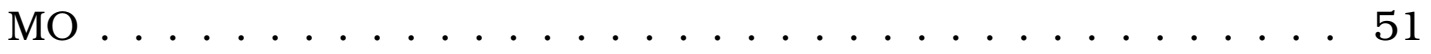


3.3 Cromatograma da 3-[(1-metil-hexil)amino]propanonitrila (9) por cromatografia a gás em coluna DB-5 . . . . . . . . . . 53

3.4 Espectro de massas TOF da 3-[(1-metil-hexil)amino]propanonitrila

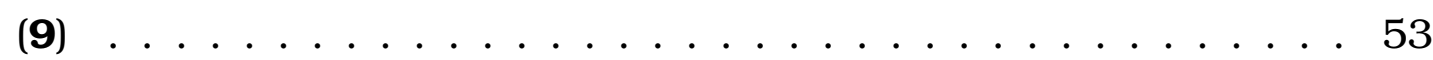

3.5 Espectro de Infra-vermelho da 3-[(1-metil-hexil)amino]propanonitrila (9)

3.6 Cromatograma da 3-[(1-metil-3-fenilpropil)amino] propanonitrila (10) por cromatografia a gás em coluna DB-5 . . . . . . . . 55

3.7 Espectro de massas TOF da 3-[(1-metil-3-fenil-propil)amino] propanonitrila (10) . . . . . . . . . . . . . . . 56

3.8 Espectro de Infra-vermelho da 3-[(1-metil-3-fenil-propil)amino] propanonitrila (10) . . . . . . . . . . . . . . . 56

3.9 Cromatograma da 3-(1,2,3,4-tetra-hidronaftaleno-1-amino) propanonitrila (12) por cromatografia a gás em coluna DB-5 . . . . 57

3.10 Espectro de Infra-vermelho da 3-(1,2,3,4-tetra-hidronaftaleno-1amino) propanonitrila (12) . . . . . . . . . . . . . 5 58

3.11 Cromatograma da 3-[(2-metil-cicloexil)amino] propanonitrila (11) por cromatografia a gás em coluna DB-5 . . . . . . . . . . 59

3.12 Espectro de massas TOF da 3-[(2-metil cicloexil)amino] propanonitrila (11) . . . . . . . . . . . . . . . . . . . . . . 59

3.13 Espectro de infra-vermelho da 3-[(2-metil cicloexil)amino] propanonitrila (11) . . . . . . . . . . . . . . . . 60

3.14 Estrutura da lipase de Candida rugosa . . . . . . . . . . . . . . 64

3.15Adição de Michael da ciclohexanona e acetilacetona na presença de lipases . . . . . . . . . . . . . . . . . . 65

3.16 Compostos utilizados por Souza et al. (2009) e Torre et al. (2004) em reações de adição de Michael . . . . . . . . . . . . . . 67

4.1 Etapas do protocolo de extração do DNA genômico bacteriano . 74

4.2 Etapas do protocolo de extração do produto de PCR . . . . . . 76

4.3 Mapa do vetor de clonagem pGEM-T Easy (PROMEGA) $\ldots . .77$

4.4 Mapa do vetor de expressão pET-23a(+)(Novagen) . . . . . . . . . 79

4.5 Mapa do vetor de expressão pET-28a (Novagen) . . . . . . . . . . . 81

4.6 Etapas do protocolo de extração de DNA plasmidial . . . . . . . 85

4.7 Esquema geral da reação de oxidação de etanol a acetona no teste de atividade enzimática de $\mathrm{ADH}$ de $B$. subtilis . . . . . . . . . . 88

4.8 Fluxograma das etapas envolvidas no desenvolvimento deste trabalho frente a clonagem, expressão e atividade enzimática de ADH de B. subtilis. . . . . . . . . . . . . . . . . . . . . 90 
4.9 Kit AxyPrep DNA Genômico Bacteriano Miniprep (AXYGEN) . . . . 91

4.10 Oligonucleotídeos iniciadores (primers), constituídos a partir das sequências de $\mathrm{DNA}$ da $\mathrm{ADH}$. . . . . . . . . . . . . . . 92

4.11 Início e fim da sequência de bases do DNA da $\mathrm{ADH}$ de $B$. subtilis retirado do GenBank . . . . . . . . . . . . . . . 93

4.12 Identificação dos elementos utilizados na construção dos primers. 93

4.13 Etapas de replicação do DNA através de PCR . . . . . . . . . . . . 94

4.14 Eletroforese em gel de agarose 0,8\% e PCR QIAquick Gel Extraction Kit (GIAGEN) . . . . . . . . . . . . . . . . . 95

4.15 Padrão do marcador molecular com a comparação da intensidade das bandas relacionada com a concentração das mesmas . . . . . 96

4.16Clonagem molecular e seus estágios de ligação do fragmento de DNA de interesse ao plasmídeo e inserção do DNA recombinante na célula hospedeira (transformação) . . . . . . . . . . . . . 97

4.17 Plaqueamento seletivo e PCR de colônia . . . . . . . . . . . . . . 98

4.18 Kit de purificação do DNA plasmidial - GeneJET $^{\mathrm{TM}}$ Plasmid Miniprep Kit (Fermentas) . . . . . . . . . . . . . . . . . . . . 99

4.19 Clivagem do DNA plasmidial (pGEM-T-Easy::ADH) com enzimas de restrição NdeI e EcoRI . . . . . . . . . . . . . . . . . . 100

4.20Trecho da análise do sequenciamento automático do recombinante pGEM-T easy::ADH, mostrando a boa qualidade dos dados obtidos evidenciada devido à presença de picos finos . . . . . . . . 101

4.21 Comparação do DNA sequenciado (b) com o fornecido pelo banco de dados GenBank (a) mostrando a mutação conservativa no resíduo 278. . . . . . . . . . . . . . . . . . . 101

4.22 Bases nitrogenadas purinas (adenina e timina) e pirimidinas (citosina e timina). . . . . . . . . . . . . . 101

4.23Teste de clivagem do pET-23a para liberação do inserto (ADH) . . 103

4.24 Géis de poliacrilamida 15\% frente à expressão da $\mathrm{ADH}$ de B. subtilis 106 4.25SDS-PAGE da purificação da ADH expressa de B. subtilis solubilizada com MPD . . . . . . . . . . . . . . . . 108

4.26SDS-PAGE da purificação da ADH solubilizada com Triton X-100 109

A. 1 Espectro de $\mathrm{RMN}$ de ${ }^{1} \mathrm{H}$ da $N$-(1-metil-hexil)acetamida (4) em $\mathrm{CDCl}_{3} \ldots \ldots \ldots \ldots \ldots \ldots 13$

A.2 Espectro de $\mathrm{RMN}$ de ${ }^{13} \mathrm{C}$ da $N$-(1-metil-hexil)acetamida (4) em $\mathrm{CDCl}_{3} \ldots \ldots \ldots \ldots \ldots \ldots 114$

A.3 Espectro de $\mathrm{RMN}$ de ${ }^{1} \mathrm{H}$ da $N$-(2-metil-ciclo-hexil) acetamida (8) em $\mathrm{CDCl}_{3}$. . . . . . . . . . . . . . . . . . 114 
A.4 Espectro de RMN de ${ }^{13} \mathrm{C}$ da $\mathrm{N}$-(2-metil-ciclo-hexil) acetamida (8)

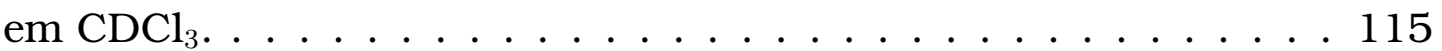

A.5 Espectro de RMN de ${ }^{1} \mathrm{H}$ da $\mathrm{N}$-(1-metil-3-fenilpropil) acetamida (6) em $\mathrm{CDCl}_{3} \ldots \ldots \ldots \ldots \ldots \ldots \ldots \ldots \ldots$

A.6 Espectro de RMN de ${ }^{13} \mathrm{C}$ da $N$-(1-metil-3-fenilpropil) acetamida (6) $\mathrm{em} \mathrm{CDCl}_{3} \ldots \ldots \ldots \ldots \ldots \ldots \ldots$

A.7 Espectro de RMN de ${ }^{1} \mathrm{H}$ da $N$-(1,2,3,4-tetra-hidronaftaleno) acetamida (7) em $\mathrm{CDCl}_{3} . \ldots \ldots$. . . . . . . . . . . . . . . 116

A.8 Espectro de RMN de ${ }^{13} \mathrm{C}$ da $N$-(1,2,3,4-tetra-hidronaftaleno) acetamida (7) em $\mathrm{CDCl}_{3} . \ldots \ldots \ldots \ldots$. . . . . . . . . . 117

A.9 Espectro de RMN de ${ }^{1} \mathrm{H}$ da 3-[(1-metil-hexil)amino]propanonitrila (9) $\mathrm{em} \mathrm{CDCl}_{3} \ldots$. . . . . . . . . . . . . . . . . . . . . 118

A. 10Espectro de RMN de ${ }^{13} \mathrm{C}$ da 3-[(1-metil-hexil)amino]propanonitrila

(9) em $\mathrm{CDCl}_{3} \ldots \ldots \ldots \ldots \ldots \ldots$. . . . . . . . . . . . 119

A. 11 Espectro de $\mathrm{RMN}$ de ${ }^{1} \mathrm{H}$ da 3-[(1-metil-3-fenilpropil)amino] propanonitrila (10) em $\mathrm{CDCl}_{3}$. . . . . . . . . . . . . . . . . . . 119

A. 12Espectro de RMN de ${ }^{13} \mathrm{C}$ da 3-[(1-metil-3-fenilpropil)amino] propanonitrila (10) em $\mathrm{CDCl}_{3} \ldots \ldots \ldots \ldots$. . . . . . . . 120

A. 13Espectro de RMN de ${ }^{1} \mathrm{H}$ da 3-[(2-metil cicloexil)amino]propanonitrila (11) em $\mathrm{CDCl}_{3} \ldots \ldots$. . . . . . . . . . . . . . . . 120

A. 14Espectro de RMN de ${ }^{13} \mathrm{C}$ da 3-[(2-metil cicloexil)amino]propanonitrila (11) em $\mathrm{CDCl}_{3} \ldots \ldots \ldots \ldots \ldots$. . . . . . . . . . . . . 121

A. 15Espectro de RMN de ${ }^{1} \mathrm{H}$ da 3-(1,2,3,4-tetra-hidronaftaleno-1-amino) propanonitrila (12) em $\mathrm{CDCl}_{3} \ldots \ldots \ldots \ldots \ldots \ldots$

A. 16Espectro de $\mathrm{RMN}$ de ${ }^{13} \mathrm{C}$ da 3-(1,2,3,4-tetra-hidronaftaleno-1-amino) propanonitrila (12) em $\mathrm{CDCl}_{3}$. . . . . . . . . . . . . . . 122 


\section{Lista de Tabelas}

2.1 Resolução enzimática de 2-amino-heptano (1) catalisada pela lipase CAL-B . . . . . . . . . . . . . . . . . . . 38

2.2 Resolução enzimática das aminas (1-4) catalisada por diferentes lipases comerciais . . . . . . . . . . . . . . 39

2.3 Resolução enzimática da 1-metil-3-fenilpropilamina (2) com lipase CAL-B . . . . . . . . . . . . . . . . . 40

2.4 Resolução enzimática de 1,2,3,4-tetra-hidro-1-naftilamina (3) catalisada por diferentes lipases . . . . . . . . . . . . . . 41

2.5 Resolução enzimática das aminas (1-4) catalisada por diferentes lipases comerciais utilizando acetato de etila como agente acilante 42

2.6 Resolução enzimática das aminas (1-4) na presença de irradiação micro-ondas ................... . . 43

2.7 Valores de rotação óptica dos produtos obtidos por resolução enzimática e da literatura . . . . . . . . . . . . . . . 45

3.1 Reação de adição de Michael entre aminas 1-4 e acrilonitrila em agitador orbital . . . . . . . . . . . . . . . 62

3.2 Adição de Michael entre 2-amino-heptano (1) e acrilonitrila - comparação da reação realizada em agitação orbital e micro-ondas 62

3.3 Adição de Michael entre aminas primárias (1-4) e acrilonitrila comparação da reação realizada em agitador orbital e micro-ondas 66

3.4 RMN de ${ }^{1} \mathrm{H}(300 \mathrm{MHz})$ e $\mathrm{RMN} \operatorname{de}^{13} \mathrm{C}(75 \mathrm{MHz})$ do composto 9 $\left(\mathrm{CDCl}_{3}, \delta\right.$ em ppm, $J$ em Hz) . . . . . . . . . . . . . . 68

$3.5 \mathrm{RMN}$ de ${ }^{1} \mathrm{H}(300 \mathrm{MHz})$ e $\mathrm{RMN}$ de ${ }^{13} \mathrm{C}(75 \mathrm{MHz})$ do composto 10

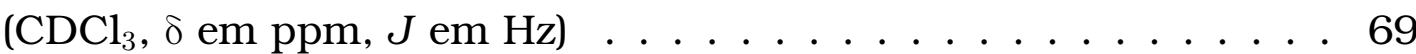

3.6 RMN de ${ }^{1} \mathrm{H}(300 \mathrm{MHz})$ e RMN de ${ }^{13} \mathrm{C}(75 \mathrm{MHz})$ do composto 11 $\left(\mathrm{CDCl}_{3}, \delta\right.$ em ppm, $J$ em $\left.\mathrm{Hz}\right) . \ldots . \ldots . \ldots 70$ 
3.7 RMN de ${ }^{1} \mathrm{H}(300 \mathrm{MHz})$ e RMN de ${ }^{13} \mathrm{C}(75 \mathrm{MHz})$ do composto 12 $\left(\mathrm{CDCl}_{3}, \delta \mathrm{em} \mathrm{ppm}, J \mathrm{em} \mathrm{Hz}\right) \ldots \ldots \ldots \ldots$

4.1 Condições testadas na expressão de ADH de B. subtilis. . . . . . . 105 


\section{Lista de Acrônimos}

ONU: Organização das Nações Unidas

DNA: Deoxyribonucleic acid (Ácido desoxirribonucléico)

ee: Excesso enantiomérico

RC: Resolução cinética

MO: Micro-ondas

ADH: Álcool desidrogenase

NAD: Nicotinamida adenina dinucleotídeo

NADH: Nicotinamida adenina dinucleotídeo na forma reduzida

NAD(P)H: Nicotinamida adenina dinucleotídeo fosfato na forma reduzida

NAD(P): Nicotinamida adenina dinucleotídeo fosfato

FDH: Formaldeído desidrogenase

CAL-B: Lipase de Candida antarctica fração B

PPL: Porcine pancreatic lipase (lipase de pâncreas suíno)

CRL: Candida rugosa lipase (lipase de Candida rugosa)

CCL: Candida cylindracea lipase (lipase de Candida cylindracea)

TLL: Thermomyces lanuginosa lipase (lipase de Thermomyces lanuginosa)

HPL: Hog pancreas lipase (lipase de pâncreas de porco)

PCL: Penicillium camenbertii lipase (lipase de Penicillium camenbertii) 
RMN ${ }^{1}$ H: Ressonância magnética nuclear de Hidrogênio

RMN ${ }^{13}$ C: Ressonância magnética nuclear de Carbono

$\mathbf{C D C l}_{3}$ : Clorofórmio deuterado

TMS: Tetrametilsilano

FID: Flame ionization detector (Detector por ionização de chama)

AcOEt: Acetato de Etila

CG: Cromatografia a Gás

MeOH: Metanol

EtOH: Etanol

c: Conversão

THF: Tetra-hidrofurano

AcOVn: Acetato de vinila

rpm: Rotações por minuto

MS: Mass spectrometry (Espectrometria de massas)

Da: Daltons

pb: Pares de bases

PCR: Polymerization chain reaction (Reação de polimerização em cadeia)

LB: Luria-Bertani (meio de cultura para cultivo de bactérias)

IPTG: Isopropyl $\beta$-D-1-thiogalactopyranoside (Isopropiltiogalactosídeo)

SDS: Dodecil sulfato de sódio

DTT: Ditiotreitol 


\section{Sumário}

1 Introdução 1

1.1 Lipases ............................ 2

1.2 Resolução enzimática de aminas . . . . . . . . . . . . 4

1.3 Promiscuidade enzimática . . . . . . . . . . . . . 10

1.4 Quiralidade ........................ 12

1.5 Adição de Michael . . . . . . . . . . . . . . . . . . . 15

1.6 Algumas reações orgânicas assistidas por irradiação micro-ondas $(\mathrm{MO}) \ldots \ldots \ldots \ldots \ldots \ldots$

1.7 Bacillus subtilis e álcool desidrogenase $(\mathrm{ADH})$ como biocatalisa-

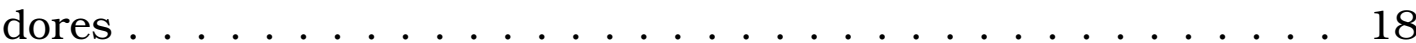

1.7.1 Bacillus subtilis como biocatalisador . . . . . . . . . . . 19

1.7.2 Álcool desidrogenases . . . . . . . . . . . . . 20

1.7.3 Mecanismo catalítico e emprego da álcool desidrogenase na redução de grupos carbonílicos . . . . . . . . . . . . 24

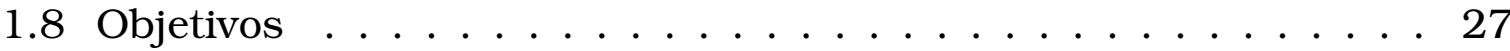

2 Resolução enzimática de aminas primárias por lipases 29

2.1 Materiais e Métodos . . . . . . . . . . . . . . . 29

2.1 .1 Enzimas ................... 29

2.1.2 Reagentes . . . . . . . . . . . . . 30

2.1.3 Equipamentos ................ 30

2.1.4 Procedimentos experimentais em escala analítica para as reações catalíticas ............... . . 31

2.1.5 Procedimentos experimentais em escala quantitativa . . . . 32

2.1.6 Dados espectroscópicos e cromatográficos . . . . . . . . . . 33

2.2 Resultados e Discussão . . . . . . . . . . . . . . . . . 37

2.3 Conclusões . . . . . . . . . . . . . . . . . 44 
3 Reações de adição de Michael catalisada por lipases 49

3.1 Materiais e Métodos . . . . . . . . . . . . . . . . . . . 49

3.1.1 Enzimas . . . . . . . . . . . . . . . 49

3.1 .2 Equipamentos ................. 50

3.1 .3 Reagentes . . . . . . . . . . . . . 50

3.1.4 Procedimentos experimentais em escala analítica . . . . . 50

3.1.5 Procedimentos experimentais em escala quantitativa . . . . 51

3.1.6 Dados espectroscópicos e cromatográficos . . . . . . . . . 52

3.2 Resultados e Discussão . . . . . . . . . . . . . . . . . . . . 61

3.3 Conclusões . . . . . . . . . . . . . . . 72

4 Clonagem, expressão e purificação de álcool desidrogenase de $B$. $\begin{array}{ll}\text { subtilis para redução de cetonas } & 73\end{array}$

4.1 Materiais e Métodos . . . . . . . . . . . . . . . 73

4.1.1 Protocolo de extração do DNA genômico bacteriano . . . . . 73

4.1.2 Construção dos oligonucleotídeos iniciadores para PCR . . 73

4.1.3 Protocolo para diluição dos primers . . . . . . . . . . . . . . 74

4.1.4 Reação em cadeia da polimerase (PCR) . . . . . . . . . . . 74

4.1 .5 Eletroforese em gel de agarose . . . . . . . . . . . . 75

4.1.6 Determinação da concentração de DNA . . . . . . . . . . 75

4.1.7 Extração do produto de PCR . . . . . . . . . . . 75

4.1 .8 Vetores . . . . . . . . . . . . . . 76

4.1.9 Linhagens de bactérias Escherichia coli . . . . . . . . 82

4.1.10Meios de cultura . . . . . . . . . . . . . . . . 82

4.1 .11 Clonagem . . . . . . . . . . . . 82

4.1.12 Extração de DNA plasmidial . . . . . . . . . . . 85

4.1.13Teste de expressão de proteínas . . . . . . . . . . . . 86

4.1 .14 SDS-PAGE . . . . . . . . . . . . 86

4.1.15Protocolo de solubilização com 2-metil-2,4-pentanodiol (MPD) 87

4.1.16Protocolo de solubilização com triton-X100 . . . . . . . . . 87

4.1.17Purificação em coluna de afinidade ao níquel . . . . . . . . 87

4.1.18Teste de atividade enzimática da $\mathrm{ADH}$. . . . . . . . . 88

4.1.19Emprego da $\mathrm{ADH}$ de B. subtilis clonada na reação de redução de cetonas . . . . . . . . . . . . . . 89

4.2 Resultados e Discussão . . . . . . . . . . . . . . . . . . . 89

4.2.1 Fluxograma dos experimentos . . . . . . . . . . . . 89

4.2.2 Banco de dados e bioinformática . . . . . . . . . . . 91

4.2.3 Protocolo de extração do DNA genômico bacteriano . . . . . 91 
4.2.4 Construção dos oligonucleotídeos iniciadores para PCR (primers) . . . . . . . . . . . . . . . 91

4.2 .5 Reação em cadeia da polimerase (PCR) . . . . . . . . . . . 93

4.2.6 Determinação da concentração de DNA . . . . . . . . . . 95

4.2 .7 Clonagem . . . . . . . . . . . . . . . . 96

4.2.8 Clonagem do DNA da ADH de B. subtilis e ligação no vetor de clonagem pGEM-T- Easy . . . . . . . . . . . . . 97

4.2.9 Clivagem do DNA plasmidial com enzimas de restrição . . . 99

4.2.10Sequenciamento automático de DNA . . . . . . . . . . 99

4.2 .11 Vetores de expressão . . . . . . . . . . . . . . . 102

4.2.12 Expressão heteróloga da proteína $\mathrm{ADH}$ a partir dos vetores de expressão . . . . . . . . . . . . . 103

4.2.13Solubilização da ADH com 2-metil-2,4-pentanodiol (MPD) . 107

4.2.14 Solubilização da ADH com triton-X100 . . . . . . . . . 108

4.2.15Testes de atividade enzimática da $\mathrm{ADH}$. . . . . . . . . 109

4.2.16Emprego da $\mathrm{ADH}$ de $B$. subtilis clonada na reação de redu-

ção de cetonas . . . . . . . . . . . . . . . 109

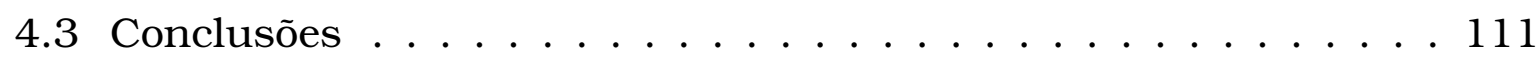

$\begin{array}{ll}\text { A Espectros de RMN } & 113\end{array}$

A. 1 Amidas . . . . . . . . . . . . . . . . . . . 113

A.2 Nitrilas . . . . . . . . . . . . . . . . . . . . 118

$\begin{array}{ll}\text { Referências } & 123\end{array}$ 
xxvi 


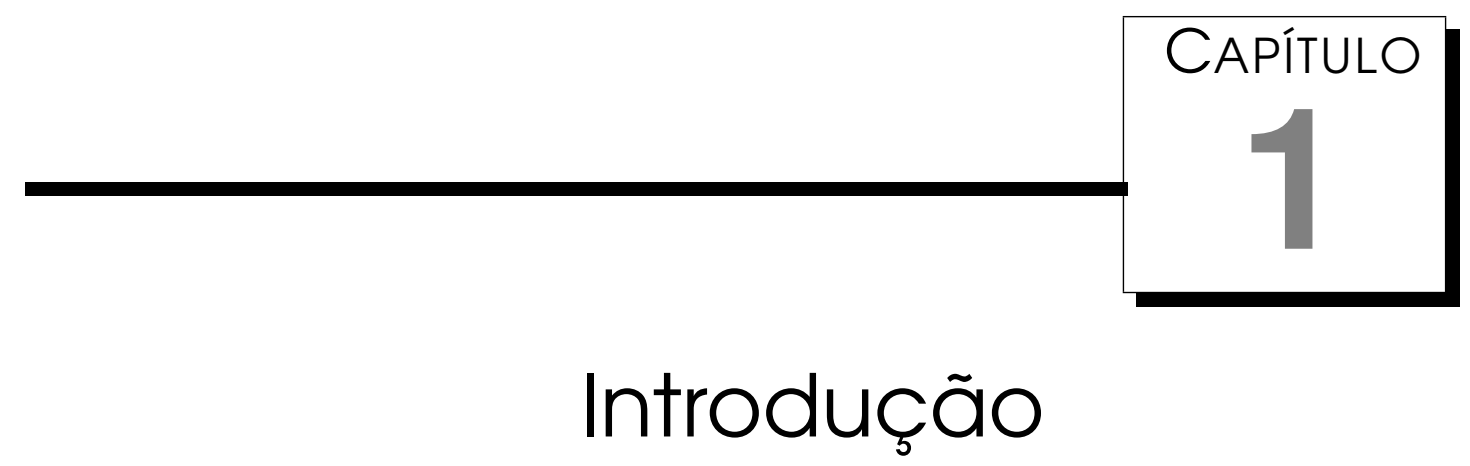

Biotecnologia é uma tecnologia fundamentada na biologia, especialmente quando usada na agricultura, ciência dos alimentos e medicina. A Convenção sobre Diversidade Biológica da Organização das Nações Unidas (ONU) possui a seguinte definição de Biotecnologia (Ader et al., 1992):

"Biotecnologia define-se pelo uso de conhecimentos sobre os processos biológicos e sobre as propriedades dos seres vivos, com o fim de resolver problemas e criar produtos de utilidade."

Uma definição mais ampla de biotecnologia é o uso de organismos vivos, ou parte deles, para a produção de bens e serviços. Nesta definição se enquadra um conjunto de atividades que o homem vem desenvolvendo há milhares de anos, como a produção de alimentos fermentados (pão, vinho, iogurte, cerveja, etc.). Por outro lado, um conceito de biotecnologia moderna está baseado no uso da informação genética, como por exemplo, as técnicas de DNA recombinante (Costa \& Borém, 2003). Na Figura 1.1 tem-se o conceito e as aplicações de biotecnologia (ORT, 2011).

A biotecnologia é uma área interdisciplinar. Desta forma o seu desenvolvimento depende da interação de várias disciplinas como a genética, a biologia molecular, a bioquímica, a embriologia, a biologia celular, as quais, por sua vez, estão vinculadas às disciplinas como a química, a microbiologia, a engenharia química, a tecnologia da informação e a robótica.

Antes do século XX, o termo biotecnologia era utilizado, principalmente, na indústria de processamento de alimentos e na agroindústria. A partir desta 
Figura 1.1: Definição de biotecnologia

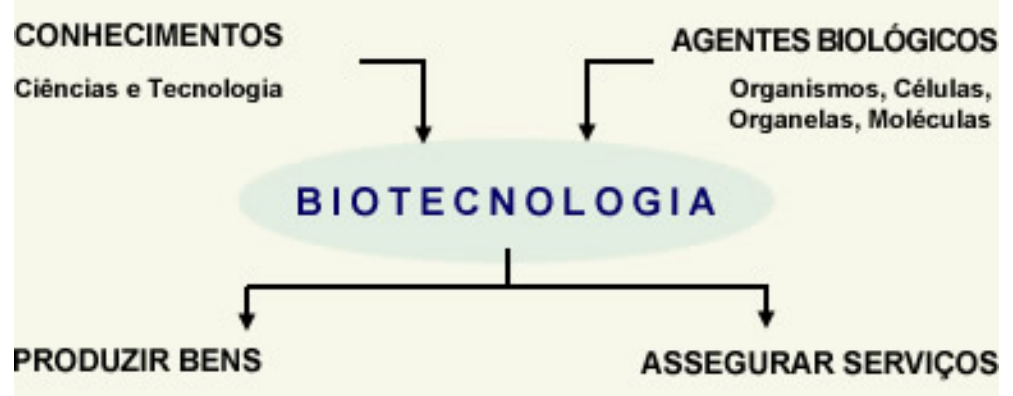

Fonte: INSTITUTO DE TECNOLOGIA ORT. O que é biotecnologia? Rio de Janeiro, 2011. Disponível em: <http://www.ort.org.br/biotecnologia/o-que-ebiotecnologia> Acesso em: 20 maio 2011.

época a biotecnologia passou a ser usada por Instituições Científicas em referência às técnicas de laboratório desenvolvidas em pesquisa biológica como os processos de DNA recombinante ou em cultura de tecidos. Em decorrência disso, o termo biotecnologia pode ser empregado num sentido muito mais amplo para descrever os diversos métodos, tanto antigos quanto modernos, usados para manipular organismos visando atender às necessidades humanas. Deste modo, o termo também pode ser definido como (Bunders et al., 1996):

"A aplicação de conhecimento nativo e/ou científico para o gerenciamento de (ou partes de) micro-organismos ou de células e tecidos de organismos superiores, de forma que estes forneçam bens e serviços para uso dos seres humanos."

\section{1 Lipases}

As lipases são enzimas da classe das hidrolases e têm um papel importante no desenvolvimento da biotecnologia. São utilizadas para a bioconversão de lipídeos (triacilgliceróis) em ácidos graxos e glicerol. Além de suas importâncias biológicas, as lipases têm um potencial de aplicação em áreas de tecnologias de alimentos, ciências biomédicas e indústrias químicas e farmacêuticas (Pandey et al., 1999). Lipases microbianas são produzidas por diversas indústrias, como Novozymes, Amano, Gist Brocades, entre outras (Castro et al., 2004).

O microbiologista C. Eijkmann relatou no ano de 1901 que inúmeras bactérias podem produzir e secretar lipases. Quando observado que as lipases permaneciam enzimaticamente ativas em solventes orgânicos (Zaks \& Klibanov, 1988) começaram a ser desenvolvidos estudos tornando estas enzimas 
em ferramentas para os químicos orgânicos. Elas se tornaram atrativas por alguns motivos:

- Normalmente exibem quimio-, regio- e estereosseletividade frente aos substratos;

- Estão disponíveis em grandes quantidades, porque muitas delas podem ser produzidas em altos rendimentos a partir de organismos microbianos (fungos e bactérias);

- As estruturas cristalinas de muitas lipases tem sido elucidadas, facilitando consideravelmente o design de estratégias racionais;

- Não precisam de cofatores e não catalisam reações laterais dependendo da natureza do substrato;

- São estáveis e catalisam reações em solventes orgânicos.

Estas propriedades tornam as lipases o grupo de biocatalisadores mais amplamente usado em química orgânica (Jaeger \& Eggert, 2002). Na Figura 1.2 são apresentadas algumas reações de hidrólise catalisadas por lipases (Bom et al., 2008).

As lipases são especialmente estáveis em solventes orgânicos (Klibanov, 1989; Zaks \& Klibanov, 1988). A facilidade com que estas enzimas aceitam uma variedade de substratos não naturais e de estruturas diversas sugere que a "espinha dorsal polipeptídica" é flexível e pode adotar diferentes conformações. Como consequência, a baixa barreira de energia que é necessária para que ocorram mudanças conformacionais dificulta a modelagem e a previsão das interações estereoquímicas para este grupo de biocatalisadores (Chen et al., 1982). Outra característica das lipases é de que as reações de esterificação por elas catalisadas em solventes orgânicos são frequentemente mais enantiosseletivas que as reações hidrolíticas correspondentes em água (Chen et al., 1982; Yamamoto et al., 1988; Bianchi et al., 1988).

O fato de enzimas manterem atividade catalítica em solventes orgânicos não possui explicação simples. A hipótese correntemente aceita é de que, quando a enzima é colocada em um solvente orgânico, esta é cineticamente "congelada" no estado nativo. Isto ocorre em parte devido à baixa constante dielétrica do meio, que produz uma maior efetividade nas forças eletrostáticas responsáveis pela manutenção da estrutura enzimática (Zaks \& Klibanov, 1988; Secundo et al., 1992). 
Figura 1.2: Reações catalisadas por lipases

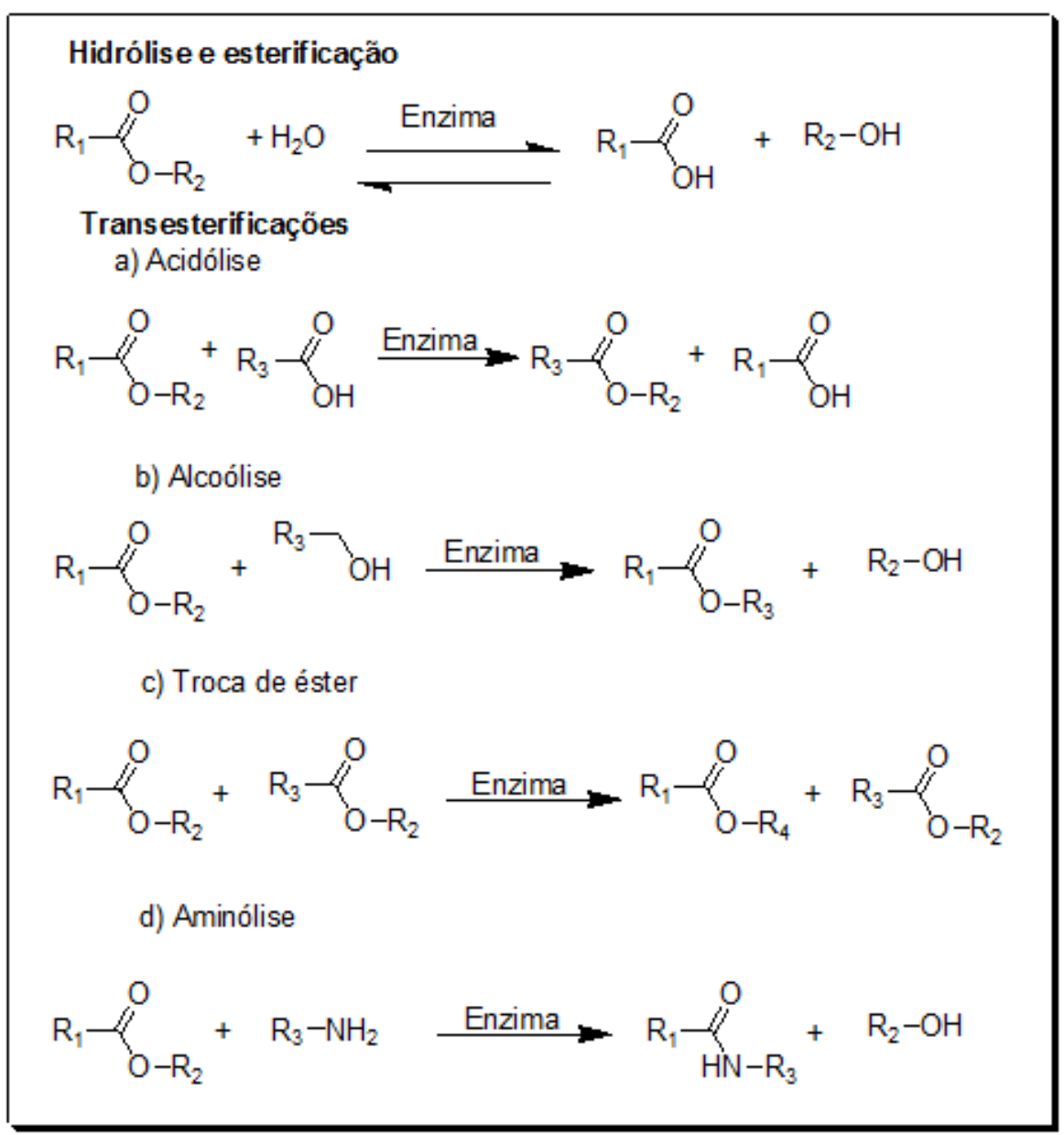

Fonte: Adaptado de BON. E. P. S.; FERRARA, M. A.; CORVO, M. L.; Enzimas em biotecnologia - produção, aplicação e mercado, Rio de Janeiro: Editora Interciência, 2008, p. 155, 309, 311, 374.

As lipases têm diversas aplicações, na produção de salsichas fermentadas a aplicação de lipases de Rhizomucor mieihei tem aspectos econômicos positivos, porque reduz o tempo de maturação com manutenção das características analíticas e sensoriais (Pandey et al., 1999). O emprego de lipases como componente funcional na formulação de detergentes é responsável pela venda de cerca de 1000 toneladas de lipases por ano ou cerca de $32 \%$ das vendas totais de lipases (Sharma et al., 2001).

O enriquecimento de óleos vegetais e animais com ácidos graxos poliinsaturados para a produção de nutracêuticos (alimentos ou parte deles que têm capacidade comprovada de trazer benefícios à saúde, como ácido linoléico) com propriedades anticarcinogênicas e antiescleróticas (Sehanputri \& Hill, 1999; Garcia et al., 1998). A esterificação de ácido 2-cloro-butírico com 1,2-epóxi-5hexeno catalisada por lipase imobilizada de Rhizomucor miehei (Lipozyme $^{\circledR}$ IM) 
foi estudada por Garcia (2000), para a produção de um éster, utilizado como intermediário na síntese de taxol, um fármaco anticâncer, alcançando conversões de até $85 \%$ dependendo das condições experimentais utilizadas (Garcia et al., 2000).

\subsection{Resolução enzimática de aminas}

Lipases têm grande importância no desenvolvimento da biocatálise, que tem se mostrado uma ferramenta relevante da biotecnologia na síntese de compostos opticamente ativos, obtidos pela resolução cinética (enzimática) via hidrólise de um substrato racêmico, por exemplo. Um pré-requisito é que a enzima seja $R$ ou $S$-seletiva. Na Figura 1.3 são apresentados três casos hipotéticos com dois exemplos para a resolução cinética seletiva sendo que se pode observar de (a) para (c) a hidrólise e a acetilação catalisada por lipase (Grunwald, 2009).

Figura 1.3: Exemplos de resolução cinética

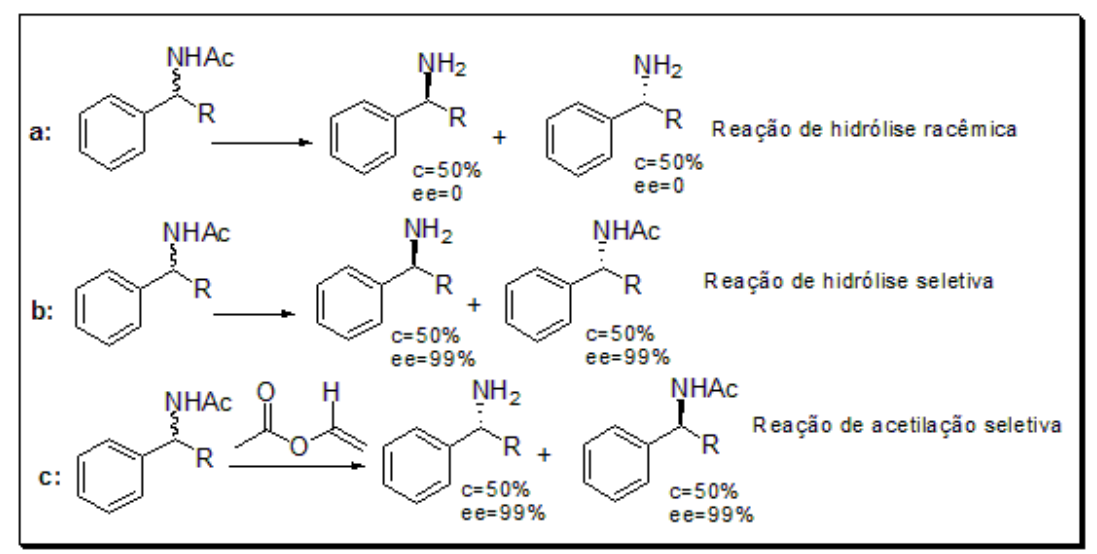

Sendo R um grupamento alquílico ou arílico. a) Hidrólise não seletiva de ésteres. b) Hidrólise enantiosseletiva de ésteres. c) Resolução cinética seletiva obtida por uma acetilação realizada em solvente orgânico.

Fonte: Adaptado de Grunwald, P., Biocatalysis - Biochemical Fundamentals and Applications, Imperial College Press, 2009, p. 230, p. 297-299.

No caso (a) a lipase é não-específica e produz o álcool racêmico. O resultado da reação (a) é a formação do produto de hidrólise que também pode ser obtido por uma saponificação alcalina do material de partida. Neste caso, a enzima não é seletiva, pois a mesma não possui a habilidade de discriminar entre os dois enantiômeros do substrato.

Na reação (b) a lipase age enantiosseletivamente levando a uma resolução cinética eficiente. A reação (c) ocorre em solvente orgânico e é um exemplo 
de resolução cinética por acetilação. O álcool vinílico utilizado como agente acilante é convertido em acetaldeído por tautomerismo ceto-enólico.

No exemplo (b) a enzima demonstra a seletividade desejada. Sob condições ótimas os dois produtos podem ser obtidos com um rendimento de 50\% de cada composto e um excesso enantiomérico (ee) de $>99 \%$. O resultado da resolução cinética depende das condições reacionais, das propriedades estruturais do substrato e do sítio catalítico da lipase. No caso de uma hidrólise com uma enzima $S$-seletiva obtém-se um $S$-álcool, desde que o grupamento R seja de menor prioridade que o aromático.

A terceira reação da Figura 1.3 mostra um exemplo de uma resolução cinética obtida por uma acetilação realizada em solvente orgânico, por exemplo, em hexano. A acetilação na presença de uma lipase seletiva tendo um doador acila, como o acetato de vinila, resulta em dois produtos enantioméricos, o álcool e o acetato.

Na prática, uma enzima que tem alta esterosseletividade pelo enantiômero $S$ de um substrato racêmico pode também reagir com o enantiômero $R$. No entanto, devido à menor complementaridade do $R$-substrato pelo sítio ativo, a energia de ativação é mais alta e a taxa de conversão a uma dada temperatura e tempo é mais lenta quando comparada com a do enantiômero $S$. Pode-se observar isso no diagrama de energia da Figura 1.4, com o curso da reação para dois substratos representando os enantiômeros $S$ e $R$ em uma mistura racêmica (Wikipedia, 2012).

O referencial teórico para este diagrama se deve aos resultados obtidos por Curtin (1954) e posteriormente complementados por Winstein e Holness (1955). É conhecido pelo termo cinética de Curtin-Hammett/Winstein-Holness e descreve o efeito das mudanças conformacionais na reatividade química (Seeman, 1983). Relacionando o excesso enantiomérico, o resultado desta teoria é uma razão entre os dois produtos $p 1$ e $p 2$ expresso pela seguinte equação (Grunwald, 2009):

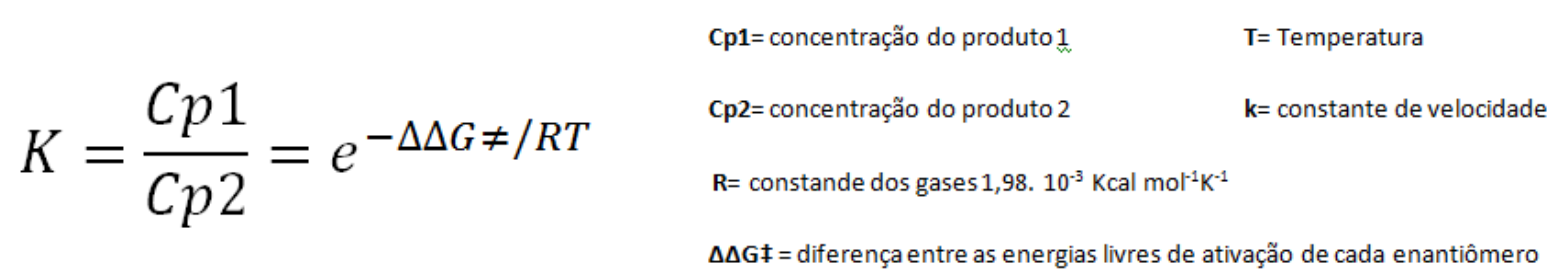

Através da razão entre as constantes $k 1 / k 2$ pode-se calcular a diferença entre as energias livres de ativação o que possibilita conhecer qual a proporção dos enantiômeros gerados como produtos: 


$$
\Delta \Delta G^{\neq}=-R T \ln \frac{k 1}{k 2}
$$

Figura 1.4: Diagrama de energia para uma reação enantiosseletiva frente a um composto racêmico

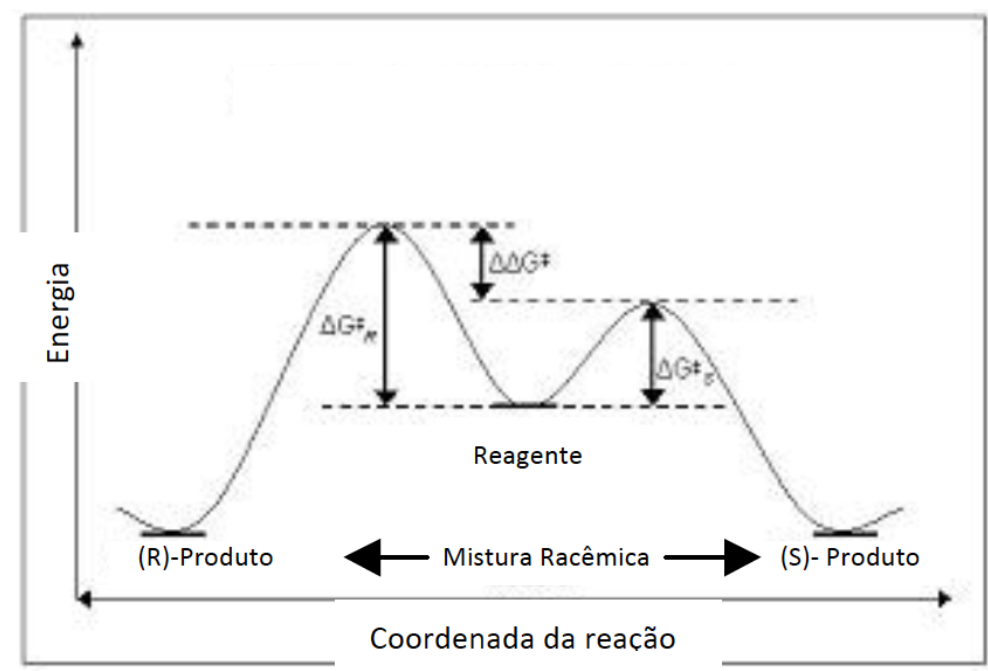

Fonte: Adaptado de WIKIPEDIA The Free Encyclopedia. Chiral Lewis acid. Disponivel em: <http://en.wikipedia.org/wiki/Chiral_Lewis_acid>. Acessado em 12 nov. 2012.

Este processo de resolução cinética foi observado pela primeira vez por Marckwald e McKenzie em 1899 na reação de esterificação do ácido mandélico racêmico com (-)-mentol opticamente ativo rendendo um par de ésteres diastereoisoméricos (Figura 1.5). Após separação dos diastereoisômeros por hidrólise foi possível obter os correpondentes ácidos mandélicos enantiomericamente puros.

Dentre as diversas aplicações de resolução de racematos destaca-se a obtenção de aminas enantiomericamente puras uma vez que são blocos de construção de grande importância na indústria química desde que são usados na síntese assimétrica de agroquímicos e produtos farmacêuticos (Breuer et al., 2004). A acilação enantiosseletiva catalisada por lipases de aminas quirais é um processo hoje realizado numa escala de toneladas/ano (Hieber \& Ditrich, 2001).

O melhor exemplo da aplicação em larga escala de lipases para resolução cinética de aminas tem sido demonstrado pela BASF. O processo utilizado pela BASF é capaz de produzir em uma escala de multi-tonelas de aminas quirais usando acilação catalisada por lipase e combinada com uma hidrólise básica da amida resultante. Esse processo tem a capacidade de produzir mais de 3000 ton/ano de aminas quirais (Figura1.6) (Nugent, 2010). 
Figura 1.5: Reação de esterificação do ácido ( \pm )-mandélico com (-)mentol catalisada em meio ácido.

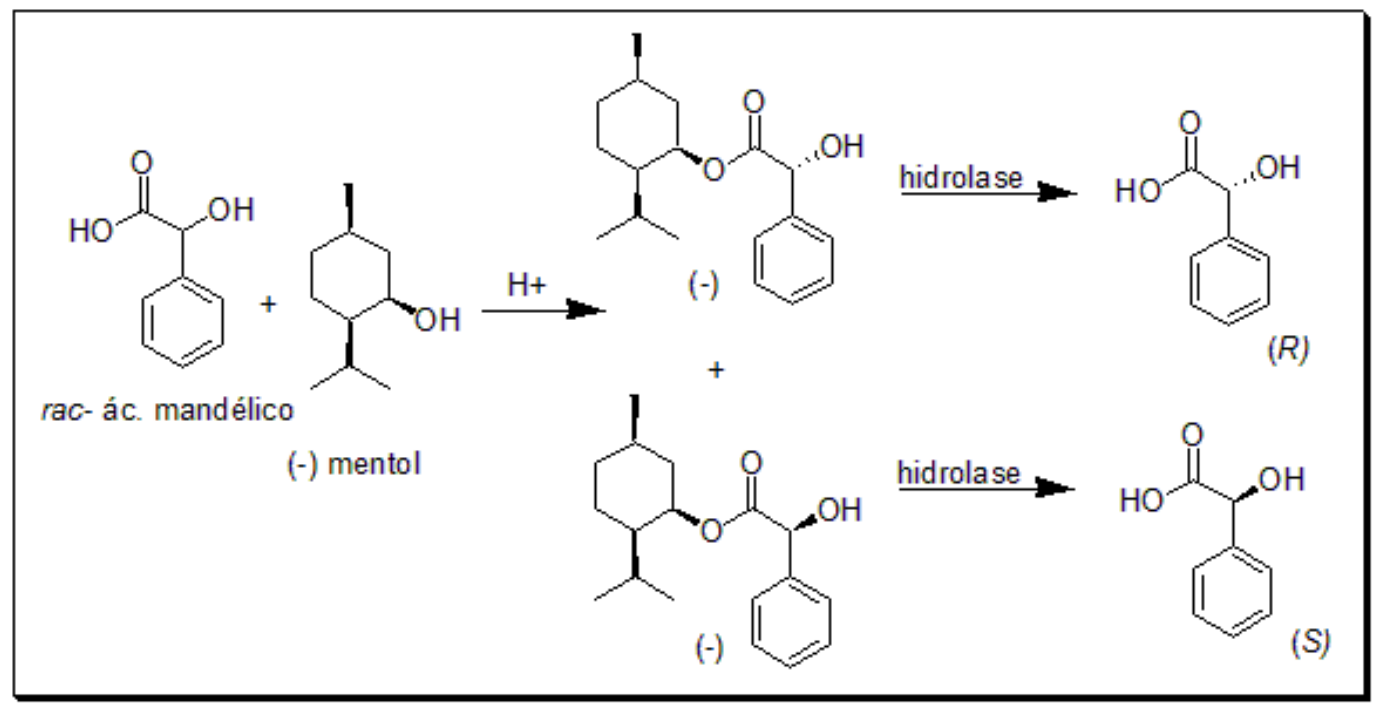

Figura 1.6: Processo BASF para a obtenção de uma variedade de aminas quirais<smiles>[R]C(N)[Hg]</smiles>

23<smiles></smiles>

25<smiles>NC1CCc2ccccc21</smiles>

10<smiles></smiles>

24<smiles>NC(c1ccccc1)C1CC1</smiles>

26<smiles>CCC(N)c1ccccc1</smiles>

27<smiles>C[14CH3]</smiles><smiles>[R]C([R])N</smiles>
alquil aminas<smiles>CCC(C)N</smiles>

20<smiles>CC(N)C1CC1</smiles>

29<smiles>CCCC(C)N</smiles>

31<smiles>CC(C)C(C)N</smiles>

28<smiles>CC(N)C(C)(C)C</smiles>

30<smiles>[R]C([R])NC(=O)COC</smiles>

amino álcoois<smiles>N[C@H]1CCCCC1OCc1ccccc1</smiles><smiles>COCC(C)N</smiles>

33<smiles>CC(N)COCc1ccccc1</smiles>

Fonte: NUGENT, T. C.; Chiral Amine Synthesis. Editora John Wiley \& Sons, p. 436-437, 2010 
Alguns exemplos de aminas enantiomericamente puras de importância e seus possiveis precursores são (Campos et al., 2000; Nechab et al., 2007):

- (a) a (S)-anfetamina que tem atividade farmacológica mais pronunciada como estimulante e agente hipertérmico que o (R)-enantiômero (Figura 1.7);

- (b) o $(R, R)$-formoterol, um potente bronco dilatador, tem como precursor a $(R)-(p)$-metoxianfetamina que pode ser obtida pela metodologia sugerida por Campos etal. (2000) (Figura 1.7);

- (c) a $(R)$-4-fenilbutan-2-amina é um precursor do anti-hipertensivo dilevalol. A $(R)$-4-fenilbutan-2-amina pode ser obtida enantiomericamente pura através da resolução cinética com CAL-B (Nechab et al., 2007) (Figura 1.7).

Figura 1.7: Aminas enantiomericamente puras ou enriquecidas de importância e possiveis precursores passiveis de sofrerem resolução cinética por biocatálise.

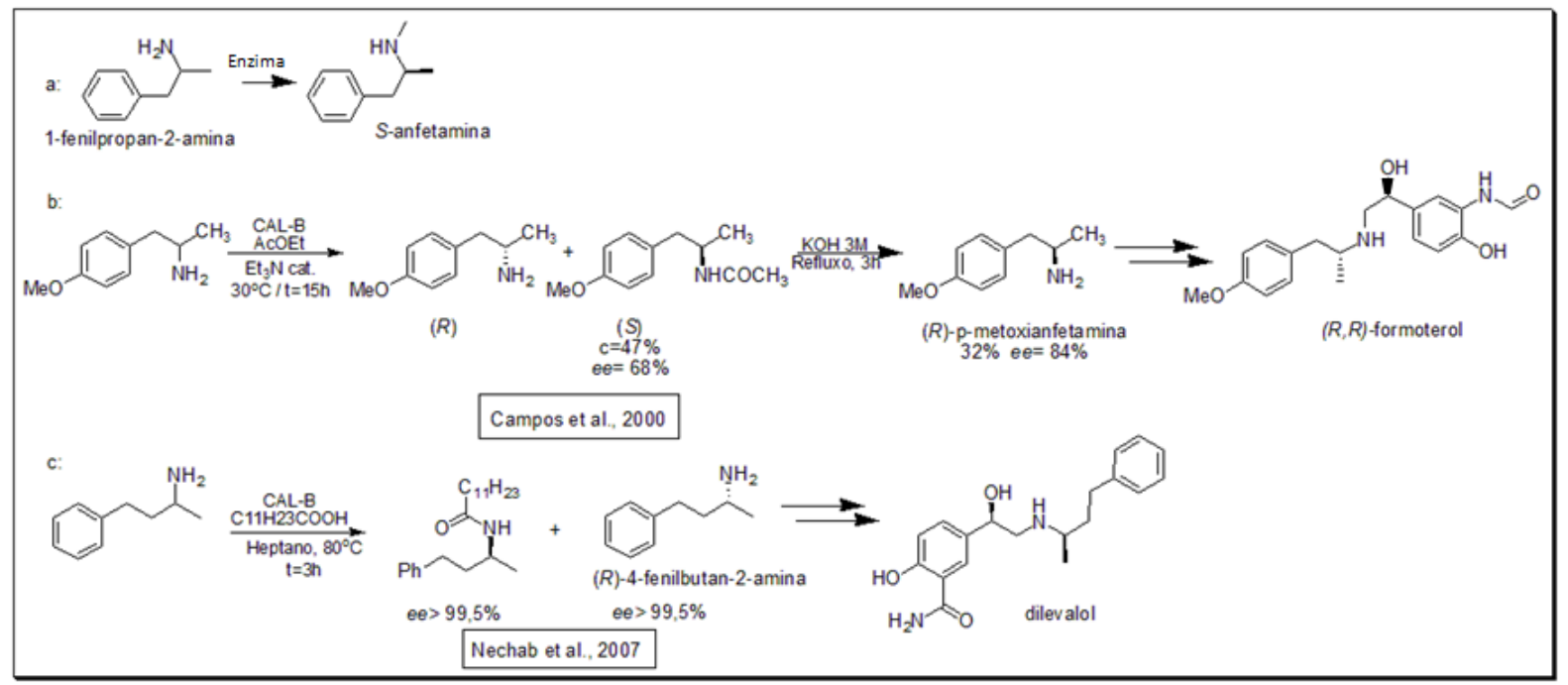

Vários métodos têm sido desenvolvidos para a produção de aminas quirais enantiomericamente puras ou enriquecidas, tais como, a hidrogenação de iminas e enaminas (Singaram \& Goralski, 1998; Blaser \& Spindler, 2000), alquilação de iminas (Denmark \& Nicaise, 2000), amino hidroxilação (Bolm et al., 2000), e aminação redutiva (Tararov \& Boerner, 2005). Devido à sua simplicidade, a resolução cinética $(\mathrm{RC})$ utilizando enzimas continua a ser um dos métodos mais eficientes para produzir aminas enantiomericamente puras ou enriquecidas e envolve a transformação (por exemplo, acilação) a partir de um enantiômero de uma mistura racêmica (Drauz et al., 1996; Bornscheuer \& 
Kazlauskas, 2006). Na Figura 1.8 tem-se o mecanismo enzimático de acilação e desacilação de aminas catalisada por lipases.

Pelo mecanismo, o grupo carboxilato do ácido aspártico atua de modo a estabilizar a histidina e esta interage com o grupo hidroxílico da serina por ligação hidrogênio, tornando-a mais nucleofílica. Isso possibilita o ataque nucleofílico do oxigênio da serina ao carbono acílico do éster formando um intermediário tetraédrico (1). Com a convergência dos elétrons do oxiânion formado para o carbono carbonílico e a transferência do próton da histidina ocorre a liberação do primeiro produto, o álcool, e forma-se a enzima acilada (complexo acil-enzima). Em seguida, um nucleófilo (neste caso uma amina), de modo análogo à formação do complexo acil-enzima, completa a hidrólise, passando pelo intermediário tetraédrico (2) e liberando o composto acilado (neste caso uma amida) e a enzima (Jaeger et al., 1999) (Jaeger et al., 1994).

Figura 1.8: Mecanismo catalítico mostrando a acilação de aminas por lipases.

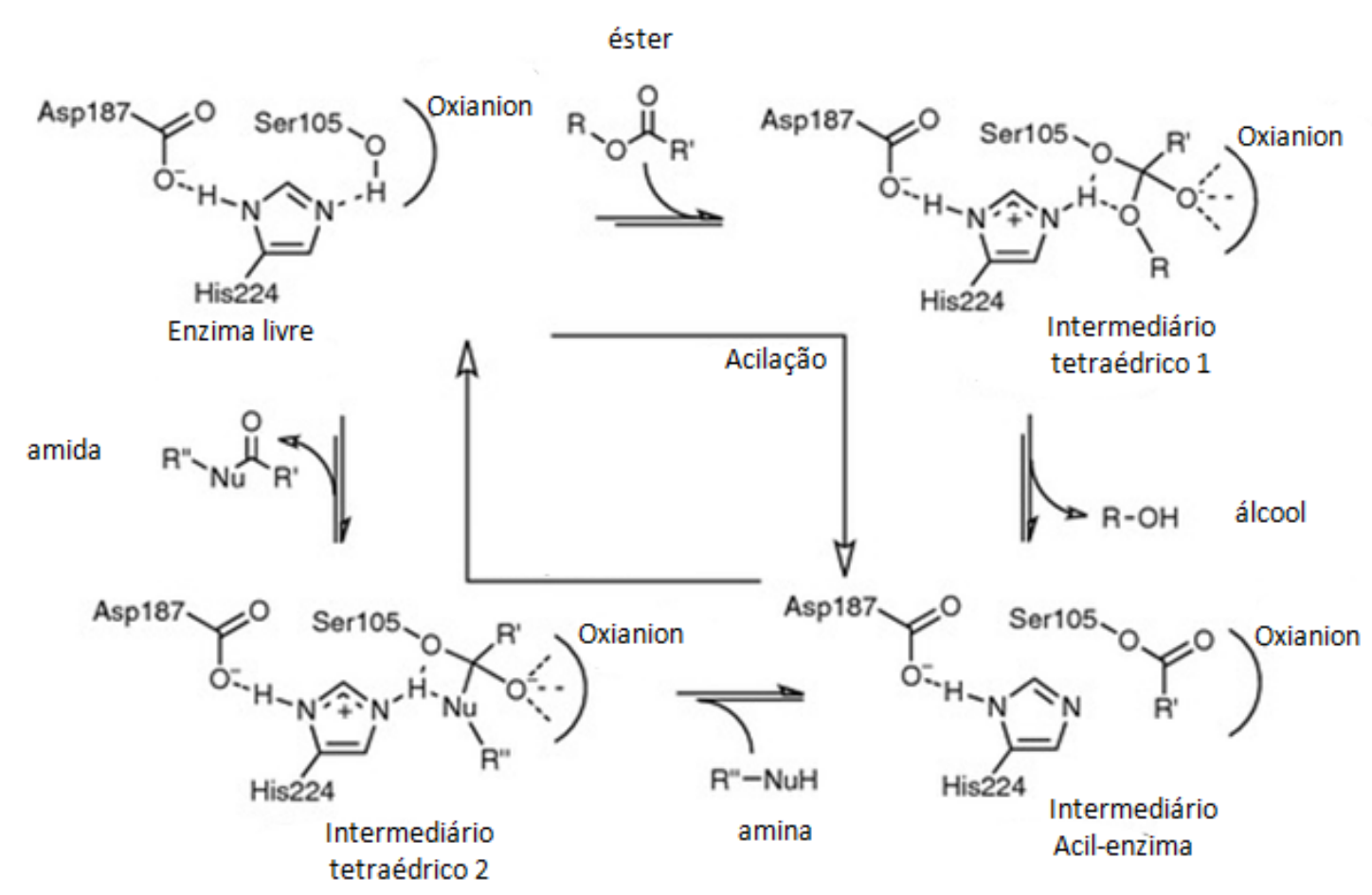

Fonte: PALMANS, R.A.; HEISE, A., Enzymatic polymerisation; Berlin: SpingerVerlag, p. 97, 2010

A capacidade de catalisar reações diferentes de sua função (promiscuidade) é uma característica importante das lipases. Isso torna possível que reações de adição de Michael sejam catalisadas por lipases, apesar de sua função natural ser direcionada a hidrólise e esterificação. 


\subsection{Promiscuidade enzimática}

Recentemente, pesquisas encontraram resultados interessantes em relação à promiscuidade das lipases. Promiscuidade neste caso significa "realizar uma reação que não é esperada” para uma determinada enzima. Por exemplo, foi observado lipases realizando diversas ligações $\mathrm{C}-\mathrm{C}, \mathrm{C}-\mathrm{N}$ e $\mathrm{C}-\mathrm{S}$ e formando produtos que refletem sua natureza promíscua. A promiscuidade da enzima pode ser classificada em três tipos: promiscuidade condicional da enzima, promiscuidade enzima-substrato e promiscuidade catalítica da enzima.

- Promiscuidade condicional está relacionada à uma atividade catalítica distinta com diferentes meios de reação ou mudança no $\mathrm{pH}$ ou da temperatura. Por exemplo, uma lipase realizando acilação em fase gasosa (SCHMID et al., 2001);

- A promiscuidade enzima-substrato está relacionada com o amplo espectro de substratos possíveis, aumentando assim sua aplicabilidade para a síntese de vários compostos orgânicos. Por exemplo, uma lipase catalisando a reação de resolução de um ácido carboxílico (Figura 1.9) (Reetz, 2002);

Figura 1.9: Resolução de um ácido carboxílico catalisada por lipase de P. Aeruginosa

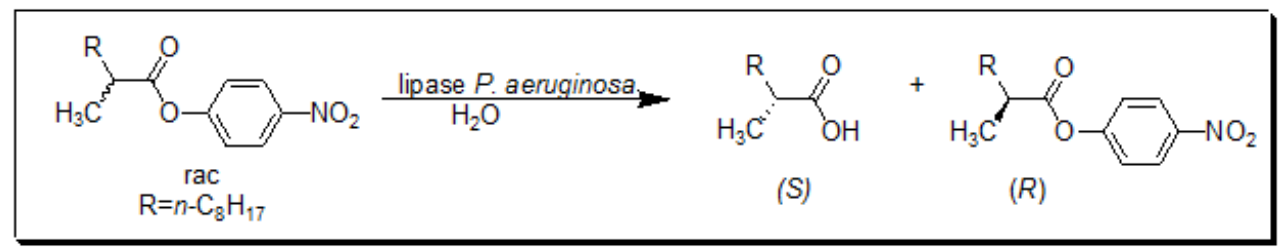

Fonte: REETZ, M. T.; Directed evolution of selective enzymes and hybrid catalysts. Tetrahedron, 58, p. 6595-6602, 2002.

- A promiscuidade catalitica da enzima varia devido a diferentes estados de transição das enzimas para catalisar reações diferentes, que pode ser acidental ou induzida (Figura 1.10). (a) Nas Serina hidrolases a carbonila do substrato (éster) se coordena na cavidade do oxiânion e então é atacada pela serina do sítio ativo. Uma mutação na serina do sítio ativo torna possível o início de outros tipos de reação que dependam da polarização da função carbonila como (b) adição aldólica ou (c) adição de Michael. O oxiânion da lipase de Candida antártica B pode formar três ligações de hidrogênio com o oxigênio do substrato no estado de transição, enquanto que no estado desativado só podem se formar duas interações (Hult \& 
Berglund, 2007). Nestes casos a natureza do substrato é importante para permitir a promiscuidade catalítica da enzima.

Figura 1.10: Estados catalíticos de transição

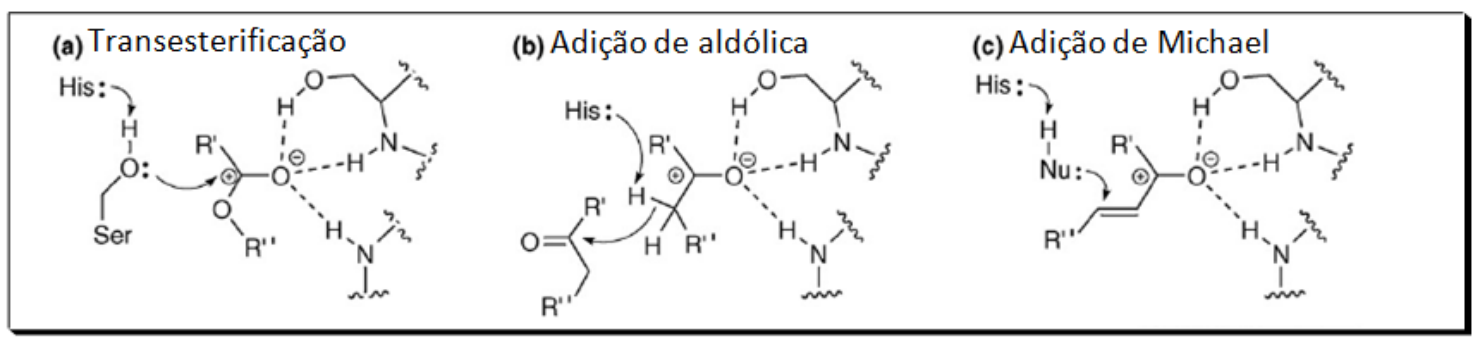

Fonte: HULT, K.; BERGLUND, P.; Enzyme promiscuity: mechanism and applications. Trends in Biotechnology, 25 (5), 2007.

\subsection{Quiralidade}

Muitas moléculas importantes e necessárias para a vida existem em duas formas enantioméricas. Estas duas formas são imagens especulares nãosuperponiveis uma a outra, elas podem ser relacionadas com as mãos esquerda e direita (Figura 1.11). Essa propriedade é chamada de quiralidade, da palavra grega para mão. As duas formas são chamadas de enantiômeros (a partir da palavra grega para oposto) ou isômeros ópticos, uma vez que desviam a luz polarizada no plano, quer para a direita ou para a esquerda (Sarfati, 1998).

Figura 1.11: Relação entre as mãos e a quiralidade
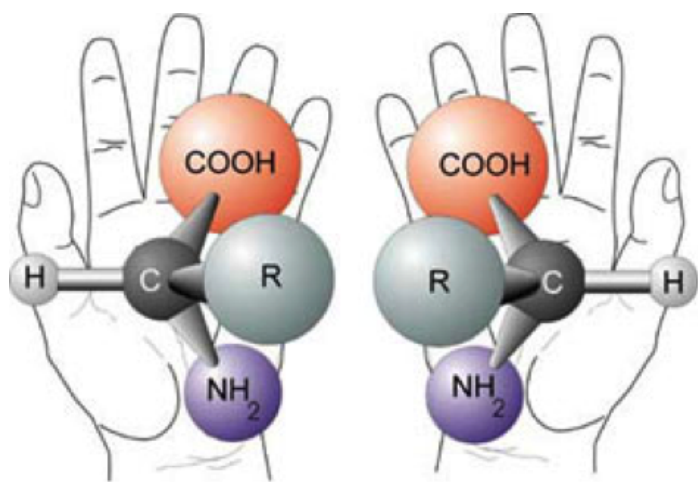

Fonte: SARFATI, J. D.; Origin of life: the chirality problem; Technical Journal, v 12 (3), p. 263-266, 1998.

Quiralidade molecular é um conceito que deriva historicamente da distinção entre os isômeros configuracionais de moléculas assimétricas, os quais foram descobertos por Pasteur e relatados em 1848 (Gal, 2010). Isômeros 
configuracionais são compostos com a mesma fórmula molecular e os mesmos grupos subtituintes, mas com configurações espaciais diferentes.

O centro assimétrico nos isômeros configuracionais é chamado de centro quiral (Johnson, 1999). Isômeros configuracionais, os quais são um subconjunto dos estereoisômeros e são denominados isômeros ópticos ou quirais, podem ser classificados como enantiômeros, espécies racêmicas (racematos) e diastereoisômeros (Reddy \& Mehvar, 2004).

Enantiômeros são pares de isômeros configuracionais que são imagens especulares um do outro e não são superponíveis. Cada enantiômero é homoquiral, o que significa que todas as moléculas têm exatamente a mesma configuração. diastereoisômeros são pares de compostos que contém mais que um centro quiral dos quais nem todos são superponíveis. Enantiômeros comportam-se diferentemente somente em um meio quiral, como por exemplo, quando expostos à luz polarizada ou quando participam em uma reação química catalisada por um catalisador quiral, particularmente uma enzima ou uma molécula quiral. diastereoisômeros geralmente exibem propriedades físicas diferentes mesmo em um ambiente aquiral (Reddy \& Mehvar, 2004).

Uma mistura equimolar de enantiômeros opostos é chamada de racemato ou espécie racêmica e é heteroquiral, significando que as moléculas têm quiralidades diferentes (Reddy \& Mehvar, 2004).

O fenômeno da quiralidade é especialmente importante em bioquímica porque muitas biomoléculas são quirais. Nos sistemas biológicos geralmente ocorre uma preferência para um dos enantiômeros da mistura racêmica. Por exemplo, a maioria dos aminoácidos nos sistemas vivos são L-enantiômeros e os D-enantiômeros ocorrem muito raramente (por exemplo, em peptídeos antibióticos). Similarmente, a maioria dos monossacarídeos são D-enantiômeros e os L-enantiômeros raramente ocorrem na natureza (Sheehan, 2009).

A quiralidade tem consequências importantes para a estrutura, forma e propriedades funcionais de biomoléculas. Por exemplo, L-aminoácidos resultam nas $\alpha$-hélices dextrorsas (hélices em formato de espiral que se dobram para a direita) observadas em proteínas. D-aminoácidos resultam em $\alpha$-hélices sinistrorsas (hélices em formato de espiral que se dobram para a esquerda) as quais são imagens especulares das $\alpha$-hélices dextrorsas. Enquanto heteropolímeros de uma mistura de D- e L-aminoácidos não podem formar hélices. Proteases são capazes de hidrolisar ligações peptídicas em polipeptídeos formados por todos os L-aminoácidos, mas não podem hidrolisar os compostos pelos D-aminoácidos (Sheehan, 2009).

Moléculas quirais são constituintes de uma grande proporção de agentes terapêuticos. Em 1984 Simonyi pesquisou em um manual sueco de fárma- 
cos em uso clínico e encontrou que de um total de 666 fármacos, 355 (53\%) tinham pelo menos um centro quiral; 181 fármacos (27\% do total) eram utilizados apenas na forma de um enantiômero, enquanto 174 (26\%) eram racêmicos (Francotte et al., 2007). Em 2002 o número de fármacos utilizados apenas na forma de um único enantiômero passou a ser de 39\% (Rouhi, 2003).

Em 1987 Ariens e Wuis estimaram que pelo menos 57\% dos fármacos comercializados são quirais (isto é, são baseados em moléculas quirais, sendo elas racêmicas, um único enantiômero, ou alguma outra mistura de estereoisômeros quirais). Também mostraram que pelo menos $55 \%$ dos fármacos quirais são usados clinicamente na forma racêmica e o restante na forma de um único enantiômero (Francotte et al., 2007). A companhia Business Communications projetava em 2003 que a receita proveniente do desenvolvimento de fármacos quirais iria continuar a crescer a uma taxa anual média de 10,2\% ao ano, de 75 bilhões em 2003 para 122 bilhões em 2008 (AMA, 2005).

Atualmente a situação é diferente. Com raras excessões, novos fármacos quirais são desenvolvidos na forma de um único enantiômero e novos fármacos racêmicos estão se tornando improváveis de surgir. Um dos principais motivos para isso é porque enantiômeros apresentam a maioria de suas propriedades físicas idênticas e, quimicamente, eles demonstram comportamentos diferentes somente em ambientes quirais. Essa característica é de extrema importância biológica uma vez que a maioria dos receptores endógenos de fármacos, como proteínas de membranas e enzimas também são compostos quirais (Romero, 1998).

A discriminação estereosseletiva de dois enantiômeros por receptores biológicos deve-se à interação espacial específica fármaco-receptor, essas interações podem levar também às diferenças farmacocinéticas. Da mesma forma, a absorção, distribuição, eliminação e, principalmente, o metabolismo de estereoisômeros podem ser altamente específicos pois, em muitos casos, são realizados por proteínas com alto grau de discriminação estereosseletiva (Caldwell, 1995; Hyneck et al., 1990).

Depois da tragédia ocorrida com a talidomida, em razão do (-)-(S)-enantiômero apresentar efeitos teratogênicos, levando, por falta de conhecimento das diferenças toxicológicas entre os enantiômeros, à má formação de milhares de fetos, novos modelos de estudos para fármacos quirais foram desenvolvidos (Caldwell, 1995). A partir de então, passou-se a estudar a influência do arranjo espacial dos átomos nas moléculas na interação com macromoléculas biológicas e o quanto isso influenciava os processos bioquímicos, fisiológicos e farmacológicos.

No Brasil, diversos pesquisadores já alertaram sobre a importância do tema 
(dos Santos et al., 2007; Lima, 1997; Coelho, 2001; Barreiro et al., 1997). Hoje, sabe-se que muitos fármacos quirais apresentam diferenças estereosseletivas significativas quanto à potência, toxicidade, absorção e metabolismo, dessa forma, as agências mundiais regulamentadoras de saúde exigem um estudo de cada enantiômero separadamente, incluindo a avaliação de racemização do centro quiral além de preconizar a comercialização de fármacos quirais na forma de enantiômeros puros (Shindo \& Caldwell, 2004).

Apesar dos importantes avanços, compostos quirais não são facilmente obtidos em seu estado puro por síntese assimétrica. Como resultado, a separação de enantiômeros permanece como uma técnica importante para obtenção de materiais opticamente ativos. Embora a separação de enantiomeros seja um procedimento tedioso o processo de obtenção de enantiômeros pode ser repetido inumeras vezes até o composto opticamente puro ser obtido (Toda, 2005).

\subsection{Adição de Michael}

Uma das reações mais utilizadas na formação da ligação carbono-carbono é a reação de Michael, convencionalmente caracterizada pela adição de nucleófilos (doadores de Michael) a olefinas ativadas (aceptores de Michael). Embora essa reação tenha sido descoberta por Komnenos e Claisen, foi efetivamente desenvolvida por Michael que a partir de 1887 relatou em uma série de artigos a adição de malonatos a enonas catalisadas por base em solventes próticos (Mattos \& Marzorati, 1999). Na Figura 1.12 é apresentada uma ilustração do mecanismo da adição de Michael da etil amina com a acrilonitrila.

Adição de Michael difere de reações de alquilação por regenerar a base no meio reacional e, devido a esse fato, apenas uma quantidade catalítica da mesma é necessária. O catalisador é utilizado em uma quantidade relativamente pequena e que aumenta a velocidade de uma reação química sem que ele próprio seja consumido (Mattos \& Marzorati, 1999).

As adições de Michael estão entre as reações mais fundamentais na síntese orgânica e são geralmente promovidas por bases duras ou ácidos fortes, o que levaria a subprodutos indesejáveis (Xu et al., 2007). Esforços contínuos têm sido realizados para desenvolver novos catalisadores para adição de Michael a fim de melhorar o rendimento da reação e evitar reações laterais, bem como promover as adições de Michael por métodos estereosseletivos.

Algumas lipases e proteases têm sido aplicadas na reação de adição do tipo Michael para formar a ligação carbono-nitrogênio e carbono-enxofre, seja em métodos convencionais ou sob efeito da irradiação micro-ondas (Monsalve 
Figura 1.12: Mecanismo da reação de adição de Michael

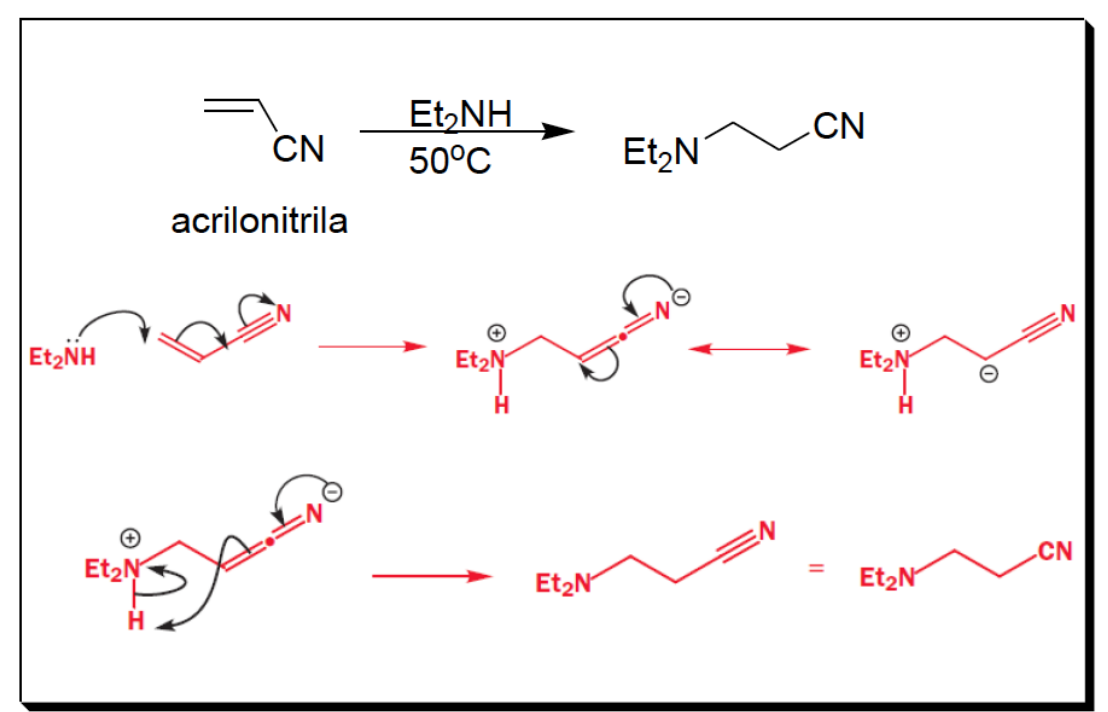

Fonte: Adaptado de CLAYDEN, J.; GREEVES, N.; WARREN, S.; WOTHERS, P.; Organic Chemistry. Oxford, 2001.

et al., 2012; Dhake et al., 2010; Pessoa et al., 2009; Cai et al., 2006; Souza et al., 2009). Na Figura 1.13 dois exemplos desta aplicação das lipases são mostrados, Monsale et al. (2012) relata que este é um meio brando e eficiente de se obter mono-adutos de Michael como único produto e com alto rendimento.

Figura 1.13: Exemplos de Adição de Michael catalisada por lipases

a) Sintese de $\beta$-amino és teres $N$-s ubstituídos (Monsale et al., 2012).

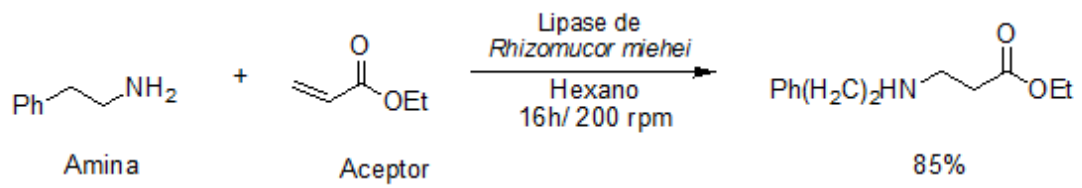

b) Síntes e de $\beta$-amino és teres N-substituídos (Dhake et al., 2010).

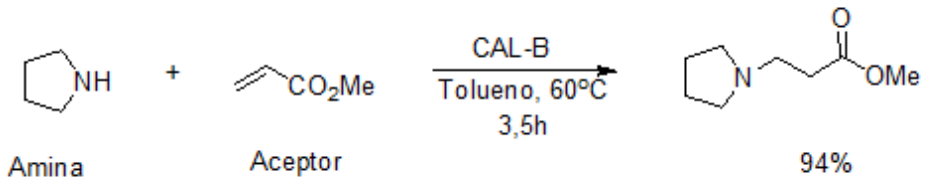




\subsection{Algumas reações orgânicas assistidas por irradia- ção micro-ondas (MO)}

A síntese assistida por irradiação micro-ondas tem atraído um interesse considerável nos últimos anos de vários grupos de pesquisa (Mavandadi \& Pilotti, 2006; Kappe, 2004). As vantagens da síntese orgânica assistida por irradiação MO incluem menores tempos de reação, maior rendimento, extração mais fácil, aplicação dos princípios da Guímica Verde, e pode aumentar a regio- e estereosseletividade das reações (Imanzadeh et al., 2007). Essa metodologia tem sido aplicada à síntese de diversos produtos naturais, bem como, peptídeos e carboidratos (Murray \& Gellman, 2005; Gorske et al., 2005; Matsushita et al., 2006; Bejugam \& Flitsch, 2004).

Estudos realizados por Réjasse et al. (2004) investigaram a transesterificação do butanoato de etila com o álcool $n$-butílico (Figura 1.14) na presença de CAL-B e em meio orgânico, comparando o aquecimento convencional e o aquecimento por MO. Com o re-uso da lipase foi observado que a taxa de conversão foi maior sob aquecimento por MO quando comparado com o aquecimento convencional. Tais resultados demonstraram que o aquecimento por MO pode evitar a termodesnaturação de enzimas, o que torna possível a utilização de enzimas sob efeito da irradiação micro-ondas com intuito de melhorar a velocidade das reações em síntese orgânica. 
Figura 1.14: Evolução da taxa de conversão com o número de re-usos do biocatalisador frente a reação de esterificação catalisada por enzima sob aquecimento clássico e irradiação MO

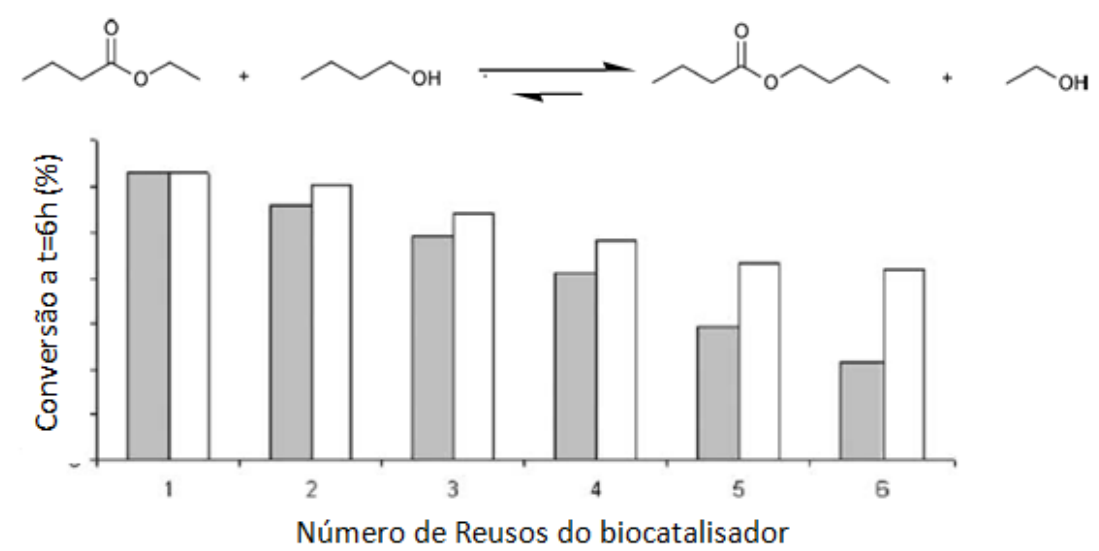

$\square$ aquecimento clássico $\square$ aquecimento por irradiação micro-ondas

Fonte: REJASSE, B.; LAMARE, S.; LEGOY, M. D.; BESSON, T., M., Stabilityy improvement of immolbilized Candida antarctica lipase B in an organic medium under microwave radiation. Organic and Biomolecular Chemistry, 2, p. 108689, 2004.

Vários trabalhos têm sugerido a utilização de MO como forma de melhorar a adição de Michael, incluindo a reação aza-Michael como demonstrado por Singh et al. (2009). Em seu estudo Singh avaliou a adição de Michael entre piperidina e acrilato de metila na presença de ácido perclórico impregnado em sílica gel como catalisador (Figura 1.15). Os resultados mostraram que a reação ocorreu com bom rendimento (98\%) e tempo reduzido (2,5 min) quando realizada na presença de MO e na ausência de solvente, tornando a metodologia por MO uma alternativa para se obter reações do tipo aza-Michael com menor tempo e maior rendimento.

Kall et al. (2010) utilizaram apenas água e aquecimento por irradiação MO em reações de aza-Michael obtendo rendimentos entre 82-99\% com tempos de 1-3 minutos para diversas aminas. Na Figura 1.16 são mostrados os resultados obtidos para a adição de pirrolidina a três aceptores diferentes aonde as reações se deram com altos rendimentos e em tempos curtos. Isso ocorreu devido a água possuir uma elevada constante dielétrica e momento dipolo que na presença de MO favoreceu a ativação da amina e do aceptor através de ligações de hidrôgenio favorecendo a reação de adição de Michael. 
Figura 1.15: Estudo comparativo da reação de adição aza-Michael entre piperidina e acrilato de metila sob várias condições utilizando ácido perclórico impregnado em sílica gel

\begin{tabular}{|c|c|c|c|}
\hline & Aceptor & & \\
\hline & Condições & Tempo & Rendimento (\%) \\
\hline 1 & $\mathrm{HClO}_{4} / \mathrm{SiO}_{2}$, T.a. & $60 \mathrm{~min}$ & 85 \\
\hline 2 & Sem catalisador, $\mathrm{CH}_{3} \mathrm{CN}, \mathrm{T}$. a. & $7 \mathrm{~h}$ & 50 \\
\hline 3 & $\mathrm{HClO}_{4} / \mathrm{SiO}_{2}, \mathrm{CH}_{3} \mathrm{CN}$, T. a. & $30 \mathrm{~min}$ & 92 \\
\hline 4 & $\mathrm{HClO}_{4} / \mathrm{SiO}_{2}, \mathrm{MO}$ & $2,5 \mathrm{~min}$ & 98 \\
\hline
\end{tabular}

Fonte: SINGH, S. P.; KUMAR, T. V.; CHANDRASEKHARAM, M.; GIRIBABU, I.; REDDY, P. Y.; Synthetic Communication, 39, p. 3982-3989, 2009.

Figura 1.16: Reação de adição aza-Michael sob o efeito da irradiação MO e meio aquoso

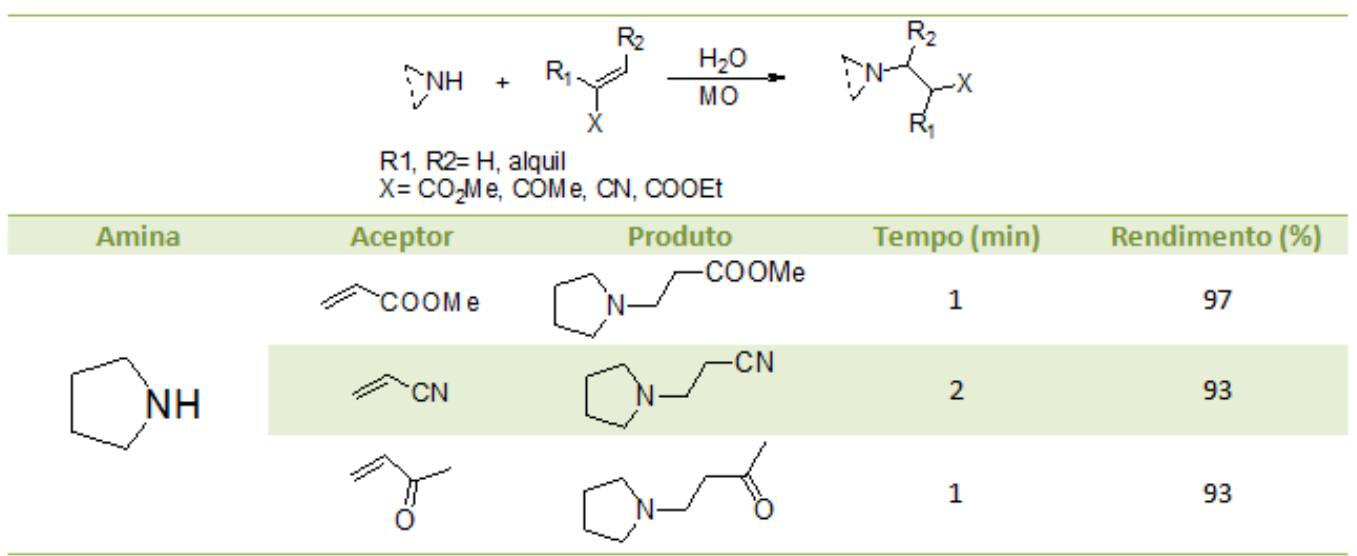

Fonte: KALL, A.; BANDYOPADHYAY, D.; BANIK, B. K. Microwave-Induced AzaMichael Reaction in Water: A Remarkably Simple Procedure; Synthetic Communication, 40 (12), p. 1730-1735, 2010.

\subsection{Bacillus subtilis e álcool desidrogenase (ADH) como biocatalisadores}

A bactéria Bacillus subtilis (Figura 1.17 - Araujo (2010); PhotoLibrary (2012)) é um bacilo Gram-positivo de solo, não patogênico, não colonizador de tecidos, naturalmente transformável (a capacidade de capturar DNA exógeno faz parte do seu ciclo de vida) e formador de esporos. Considerada modelo de estudo de bactérias Gram-positivas, o conhecimento sobre suas características genéticas e fisiológicas só encontra paralelo com aquela disponível para a Gram-negativa Escherichia coli K12.

Essas características lhe conferem vantagens para a expressão de proteínas heterólogas, valendo ressaltar que linhagens de $B$. subtilis são utilizadas a 
décadas para a produção de proteases empregadas na indústria de fabricação de detergentes e sabão em pó para fins industriais ou laboratoriais (Harwood, 1992).

Figura 1.17: Colônias de Bacillus subtilis e micrografia do B. subtilis tipo bastonetes

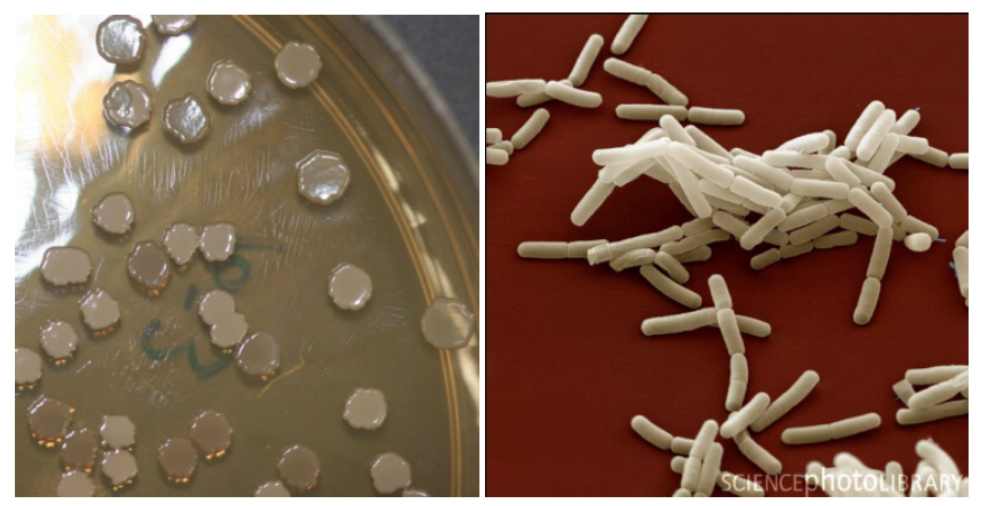

Fonte: Araujo, M. 2010 - Disponivel em: http://www.infoescola.com/reinomonera/bacillus-subtilis/) e Science photo library - Bacillus subtilis, SEM Disponivel em: http://www.sciencephoto.com/media/12288/enlarge) Acessados em: 12 nov 2012.

\subsubsection{Bacillus subtilis como biocatalisador}

Bacillus subtilis isolado de alga marinha vermelha Bostrychia tenella foi usado como biocatalisador, demonstrando uma elevada seletividade para a redução dos derivados de iodo-acetofenonas (Figura 1.18) resultando em álcoois quirais (Mouad et al., 2011). Como já é sabido as enzimas responsáveis pela redução de cetonas nos seres vivos são as álcool desidrogenases. Devido ao conhecimento da existência da $\mathrm{ADH}$ nas células de $B$. subtilis é possível racionalizar que a reação se deu através da ação desta enzima, demonstrando ser uma álcool desidrogenase seletiva para o enantiômero $S$.

Álcoois quirais são blocos de contrução para a síntese de compostos opticamente ativos como o antifúngico Brefeldina A ou o Taxol usado no tratamento de câncer (Figura 1.19 (b)). Os compostos (S)-2,3-iodofeniletanois foram usados para obter compostos quirais bifenílicos (Rocha et al., 2010), que são intermediários versáteis em síntese orgânica. Como exemplo, pode-se observar o uso de compostos bifenílicos na síntese de compostos como as colchicinas que são potentes antibióticos (Figura 1.19) (Baudoin et al., 2002).

O uso de células íntegras de $B$. subtilis como biocatalisador foi empregado por (Adam et al., 2000), que realizou a resolução cinética de 1-metil-(1fenil)propil hidroperóxido a $30^{\circ} \mathrm{C}$ obtendo $94 \%$ de conversão e excesso enanti- 
Figura 1.18: Redução de iodo-acetofenonas por B. subtilis

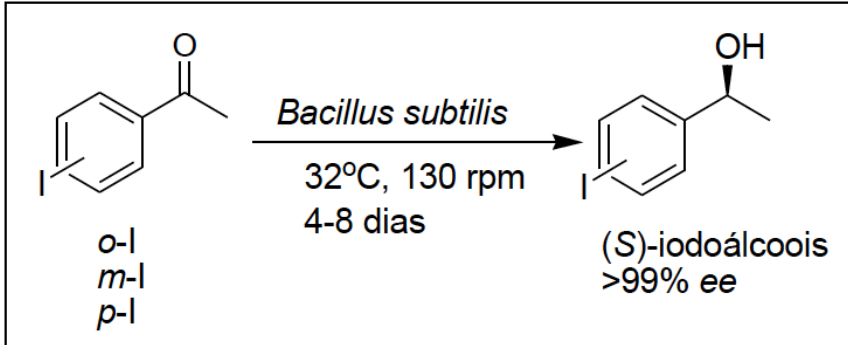

Fonte: Adaptado de MOUAD, A. M.; MARTINS, M. P.; DEBONSI, H. M.; DE OLIVEIRA, A. L. L; DE FELÍCIO, R.; YOKOYA, N. S.; FUJJI, M. T.; DE MENEZES, C. B. A.; FANTINATTI-GARBOGGINI, F.; PORTO, A. L. M. Bioreduction of acetophenone derivatives by red marine algae Bostrychia radicans and $B$. tenella, and marine bacteria associated. Helvetica Chimica Acta, 94 (8), 1506-1514, 2011.

omerico >99\% para o $R$-hidroperóxido >99\% (Figura1.20).

\subsection{2 Álcool desidrogenases}

Álcool desidrogenases (EC 1.1.1.1) são enzimas desidrogenases que ocorrem em muitos organismos e promovem a interconversão de álcoois em aldeídos ou cetonas com a redução da nicotinamida adenina dinucleotídeo forma oxidada $\left(\mathrm{NAD}^{+} / \mathrm{NADP}^{+}\right.$) para a forma reduzida (NADH ou NADPH).

Nos seres humanos e em outros animais, ADH's servem para degradar álcoois que são tóxicos e também participam na geração de aldeídos, cetonas, ou outros álcoois envolvidos na biossintese de metabólitos. Em leveduras, plantas e em muitas bactérias, algumas álcool desidrogenases catalisam a reação oposta como parte da fermentação para garantir um fornecimento constante de $\mathrm{NAD}^{+}$(Corporation, 2011).

$\mathrm{O} \mathrm{NAD}^{+}$é utilizado na fermentação alcóolica onde participa da oxidação do piruvato a etanol com liberação de $\mathrm{CO}_{2}$ e NADH (Figura 1.21) (Heller et al., 1998). O NADH é então utilizado pelas álcool desidrogenases que devolvem o $\mathrm{NAD}^{+}$para a via glicolítica. A incapacidade de regenerar o $\mathrm{NADH}$ em $\mathrm{NAD}^{+}$ deixaria a célula sem receptor de elétrons para a oxidação do giceraldeído-3fosfato e as reações liberadoras de energia da glicose cessariam (Nelson et al., 2001). A Figura 1.22 apresenta a estrutura de uma álcool desidrogenase bacteriana e seu sítio ativo na Figura 1.23/citepkorkhin1998nadp. 
Figura 1.19: Reação de Suzuki entre derivados de (S)-feniletanois e ácido borônico

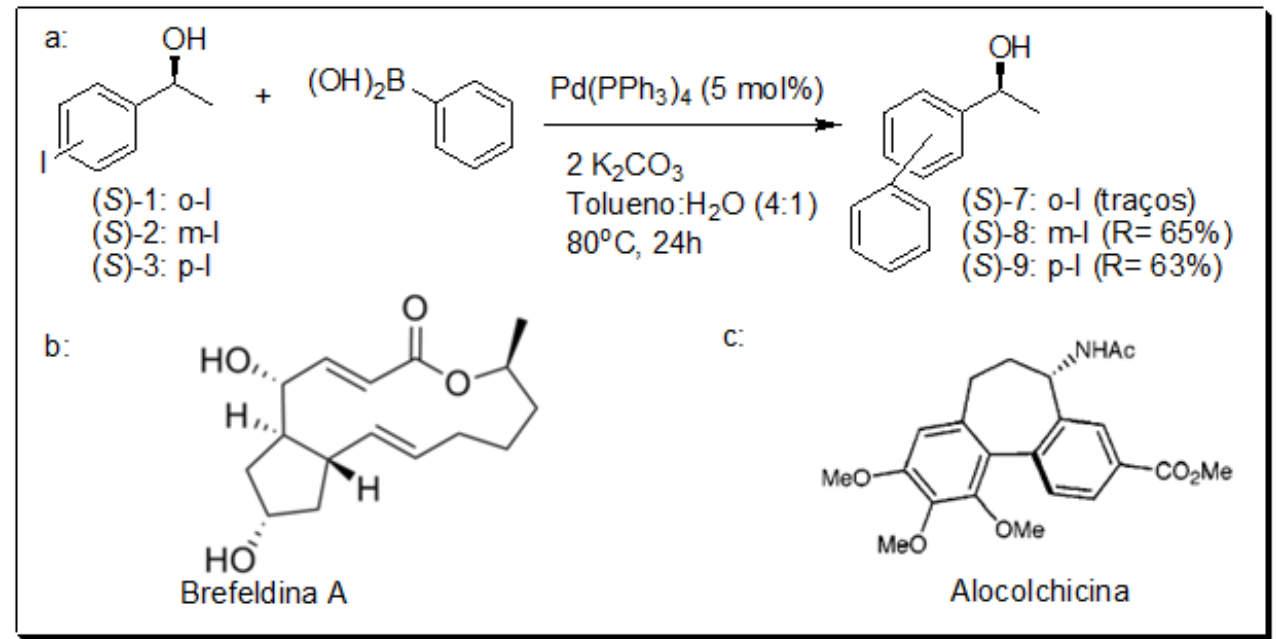

a) Reação de Suzuki catalisada por paládio entre (S)-alcoóis e ácido fenilborônico (Rocha et al., 2010). b) Estrutura do antifúngico Brefeldin A. c) Estrutura do antibiótico alocolchicina

Figura 1.20: Resolução cinética do 1-metil-(1-fenil)propil hidroperóxido por B. subtilis

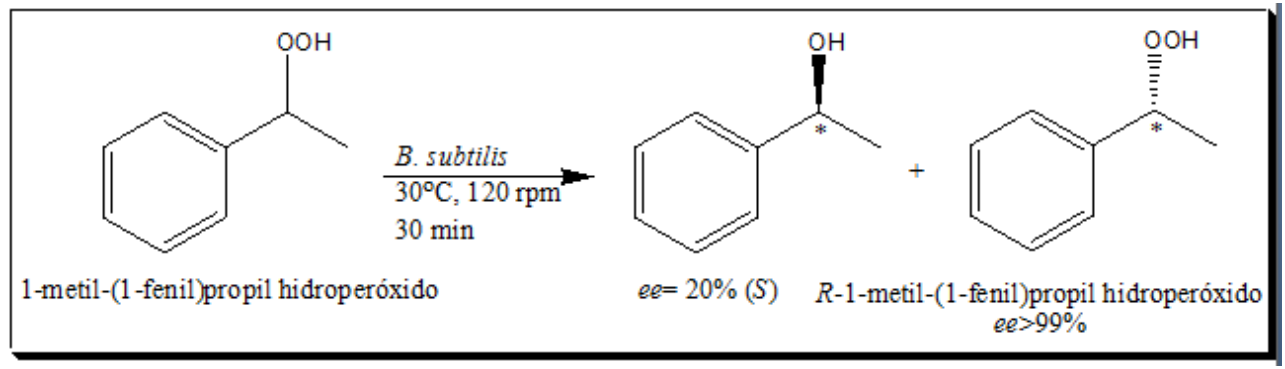


Figura 1.21: Esquema simplificado de fermentação alcóolica da glicose

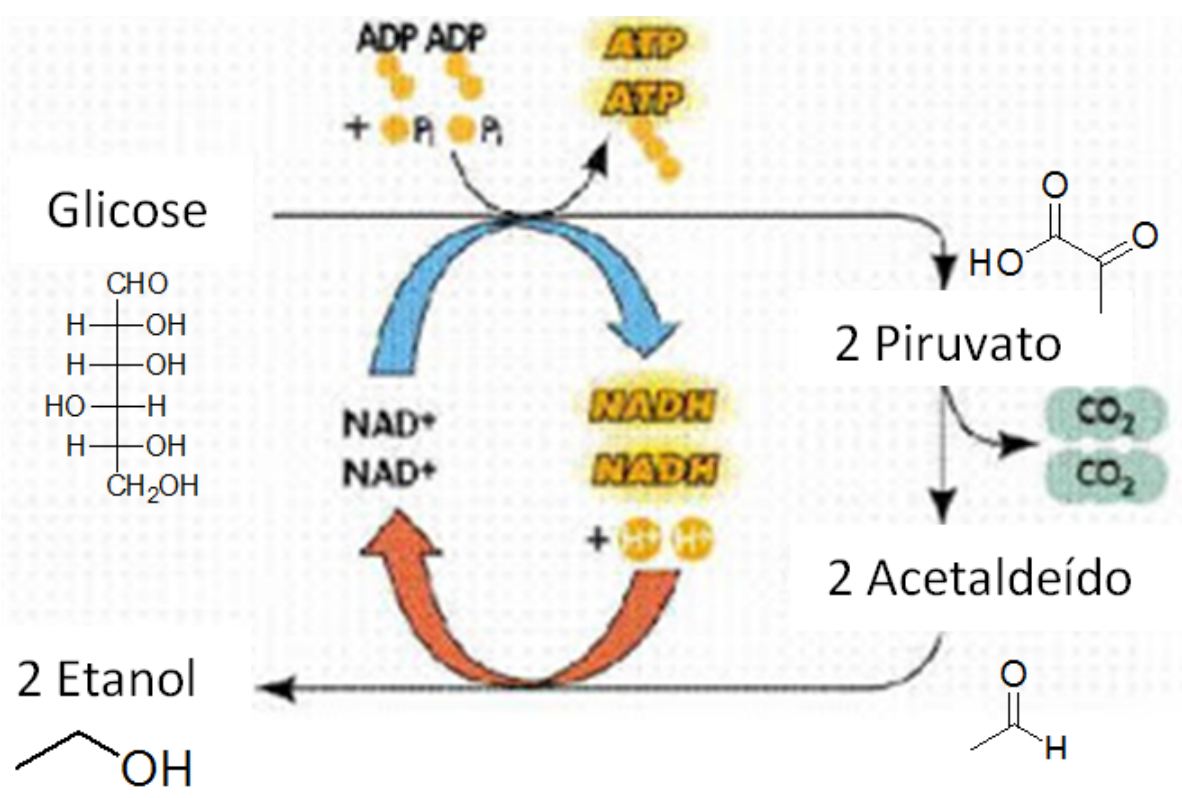

Fonte: HELLER, H. C. and ORIANS, G. H. and PURVES, W. K.;Life: The Science of Biology, (4th edition) 1998.

Figura 1.22: Estrutura protéica da álcool desidrogenase bacteriana de Clostridium beijerinckii e ampliação do sítio ativo com seus ligantes $\mathrm{Zn}^{2+}$ e o cofatoR NAD ${ }^{+}$

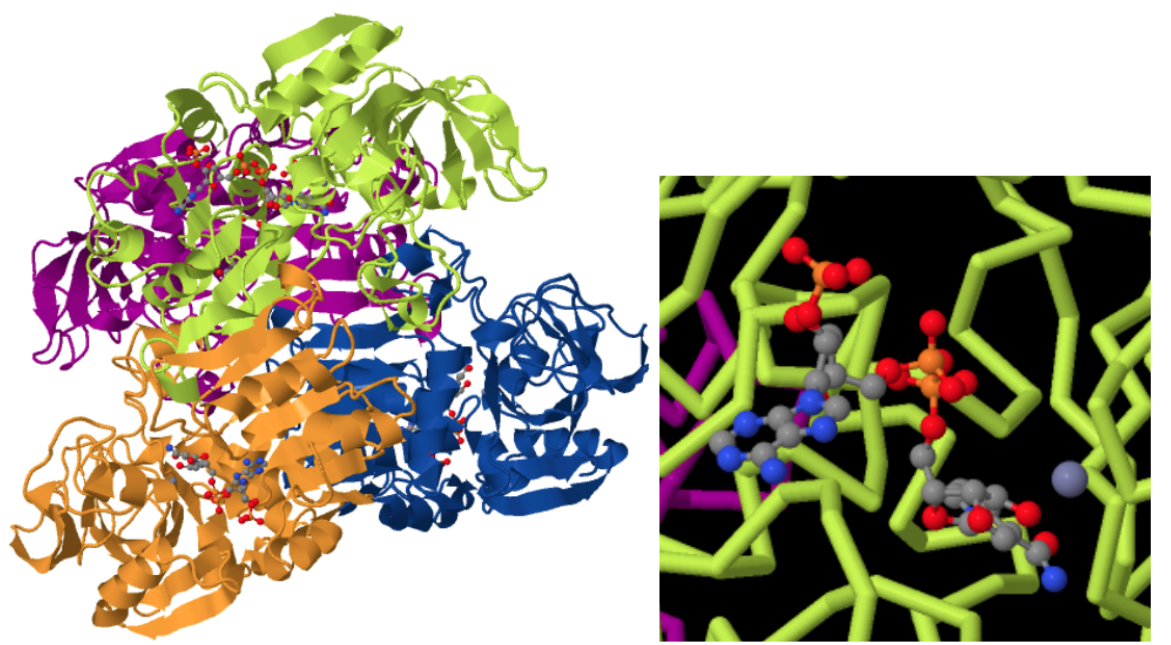

Fonte: KORKHIN, Y. and KALB, G.A.J. and PERETZ, M. and BOGIN, O. and BURSTEIN, Y. and FROLOW, F. and others; NADP-dependent bacterial alcohol dehydrogenases: crystal structure, cofactor-binding and cofactor specificity of the ADHs of Clostridium beijerinckii and Thermoanaerobacter brockii; Journal of Molecular Biology; 278 (5) p. 967; 1998. Imagem retirada do Protein Data Bank, PDB ID: 1YKF 
Figura 1.23: Sítio ativo de uma álcool desidrogenase

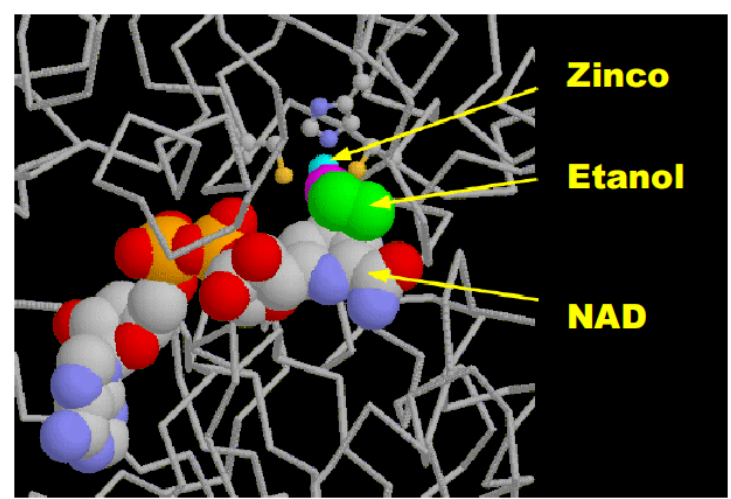

Fonte: Korkhin, Y. and Kalb, G.A.J. and Peretz, M. and Bogin, O. and Burstein, Y. and Frolow, F. and others; NADP-dependent bacterial alcohol dehydrogenases: crystal structure, cofactor-binding and cofactor specificity of the ADHs of Clostridium beijerinckii and Thermoanaerobacter brockii; Journal of Molecular Biology; v 278(5) p. 967; 1998. Imagem retirada do Protein Data Bank, PDB ID: $1 \mathrm{YKF}$ 


\subsubsection{Mecanismo catalítico e emprego da álcool desidrogenase na redução de grupos carbonílicos}

O primeiro passo da reação é a ligação do substrato (aldeídos ou cetonas) ao sítio ativo direcionada pela ligação específica do NADH. O sítio ativo contém resíduos que se projetam permitindo que somente uma face do anel da nicotinamida seja acessivel. O oxigênio carbonílico do substrato complexa com o íon $\mathrm{Zn}^{2+}$, atraindo a carga negativa para o oxigênio e tornando o carbono carbonílico parciamente positivo, fazendo com que este carbono se torne um eletrófilo melhor e mais suscetível ao ataque nucleofílico do cofator.

No próximo passo da reação o par de elétrons disponivel do nitrogênio presente na nicotinamida se desloca no anel formando uma ligação dupla e liberando o íon hidreto a fim de reestabelecer a aromaticidade. Uma vez que o anel é especificamente orientado, dos dois hidrogênios localizados no carbono 4, o mais próximo do $\mathrm{Zn}^{2+}$ transfere o íon hidreto, isto é conhecido como uma transferência de hidreto de classe $B$ (enquanto que a classe A seria a transferência de hidreto do outro hidrogênio no carbono 4). O íon hidreto age como nucleófilo atacando o carbono carbonílico do substrato reduzindo ao etóxido e completando a oxidação do $\mathrm{NADH}$ para $\mathrm{NAD}^{+}$.

No último passo o ânion etóxido é protonado pela água complexada ao $\mathrm{Zn}^{2+}$ para formar um álcool como produto final da reação (Arizona, 2013). O mecanismo simplificado esta ilustrado na Figura 1.24.

As álcool desidrogenases podem ser usadas em reações de redução como enzimas isoladas. Durante a redução de um grupo carbonila, o cofator NAD(P)H (doador de hidreto) deve ser utilizado estequiometricamente ou ser regenerado através da redução in situ do $\mathrm{NAD}(\mathrm{P})^{+}$devido aos custos elevados.

Uma possibilidade para a reciclagem de $\mathrm{NAD}(\mathrm{P}) \mathrm{H}$ fora de um organismo é a utilização de uma segunda enzima e um substrato auxiliar que será oxidado (Figura 1.25). Como exemplo, tem-se as glicose desidrogenases que oxidam a glicose, as glicose-6-fosfato desidrogenases que oxidam a glicose-6-fosfato e as álcool desidrogenases que oxidam alcoóis, todas estas enzimas oxidam seus substratos regenerando o NAD(P)H para o meio (PORTAL, 2011).

Segundo a literatura, em um meio reacional bifásico para a redução biocatalítica assimétrica de cetonas com regeneração do cofator in situ, ambas as enzimas [ADH e formaldeído-desidrogenase (FDH)] se mantêm estáveis. Reduções de cetonas pouco solúveis em água foram realizadas nas concentrações de substrato menor que $10 \mathrm{mM}$, e álcoois foram formados com boas conversões e em altas enantiosseletividades (Gröger et al., 2003) (Figura 1.26).

Frente aos temas discutidos nesta introdução o uso de processos biotec- 
Figura 1.24: Mecanismo catalítico simplificado da álcool desidrogenase

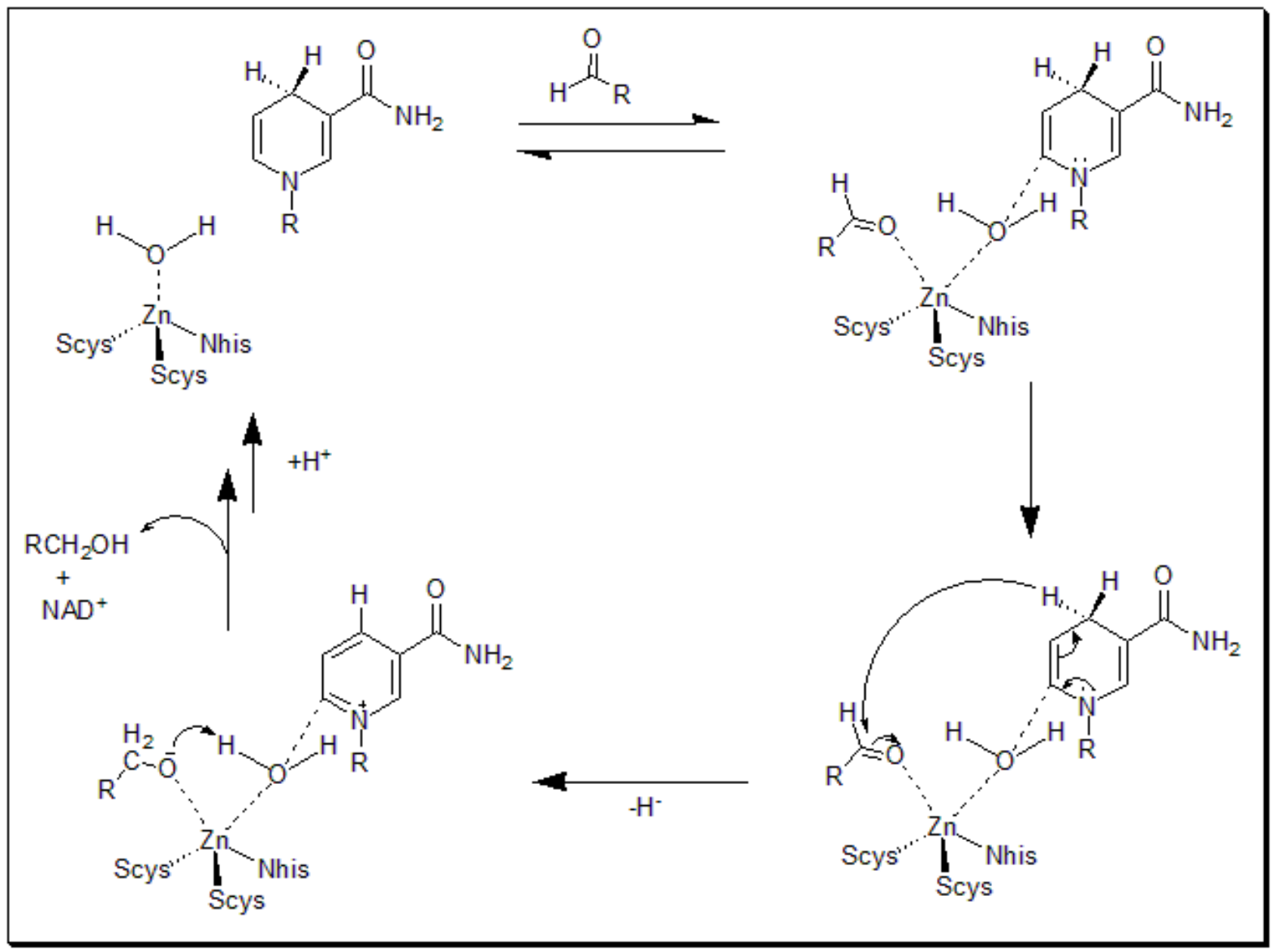

Figura 1.25: Redução de cetonas por ADH's e sistema de regeneração de cofatores

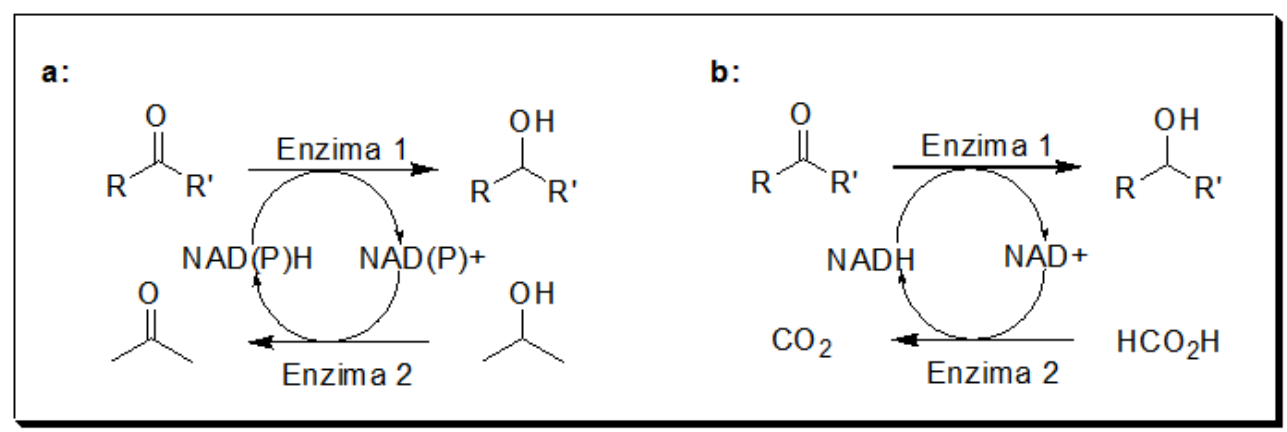

a) Redução de cetonas catalizada por uma $\mathrm{ADH}$ e oxidação de alcoóis pela própria $\mathrm{ADH}$ ou uma segunda enzima para regenerar o $\mathrm{NAD}(\mathrm{P}) \mathrm{H}$. b) Redução de cetonas pela $\mathrm{ADH}$ de leveduras e bactérias e a regeneração do NADH por uma segunda enzima na fermentação. Fonte: Adaptado de ORGANIC CHEMISTRY PORTAL. Disponivel em: <http://www.organicchemistry.org/chemicals/reductions/alcoholdehydrogenase-adh.shtm>. Acesso 30 maio 2011. 
Figura 1.26: Redução assimétrica por desidrogenase em meio bifásico

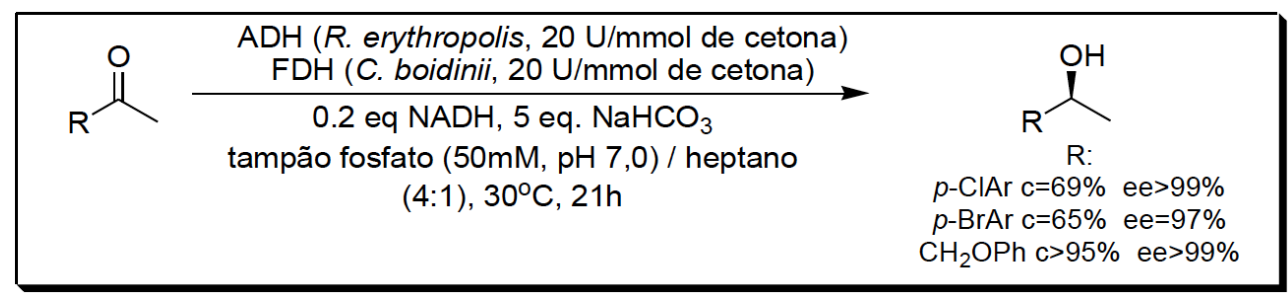

Fonte: adaptado de GROEGER, H.; HUMMEL, W.; BUCHHOLZ, S.; DRAUZ, K.; NGUYEN, T.V.; ROLLMANN, C.; HUESKEN, H.; ABOKITSE, K.;Practical asymmetric enzymatic reduction through discovery of a dehydrogenase-compatible biphasic reaction media. Organic Letters, 5 (2), p. 173-176, 2003.

nológicos mostra-se importante para a obtenção de novos produtos. Neste trabalho foi explorado o uso de enzimas para promover reações químicas com e sem o auxílio de irradiação micro-ondas. Também com foco na biocatálise, foi realizada a clonagem, expressão e purificação da álcool desidrogenase de Bacillus subtilis visando a redução de cetonas. 


\subsection{Objetivos}

- Estudo da resolução enzimática de aminas primárias por lipases.

- Estudo da adição de Michael catalisada por lipases com e sem o efeito da irradiação de micro-ondas.

- Desenvolvimento de rota sintética para obtenção de amidas e nitrilas.

- Clonagem, expressão e purificação da álcool desidrogenase de Bacillus subtilis.

- Elucidação estrutural da álcool desidrogenase de Bacillus subtilis.

- Uso da álcool desidrogenase isolada de Bacillus subtilis na redução enantiosseletiva de iodo-acetofenonas. 
CAPÍTULO

\section{Resolução enzimática de aminas primárias por lipases}

\subsection{Materiais e Métodos}

\subsubsection{Enzimas}

1. A Lipase imobilizada em resina acrílica de Candida antarctica (CAL-B), $\geq$ 10,000 U/g, recombinante, expressa em Aspergillus oryzae foi doada por Novo Nordisk (Brasil).

2. Lipase de pâncreas suíno (PPL,) 30-90 U/mg proteína. Uma unidade é capaz de hidrolisar 1,0 $\mu$ eq. de triacetina em $1 \mathrm{~h}$ com $\mathrm{pH} 7,7$ a $37^{\circ} \mathrm{C}$.

3. Lipase de Candida rugosa (CRL) tipo VII $\geq 700 \mathrm{U} / \mathrm{mg}$. Uma unidade é capaz de hidrolisar 1,0 $\mu$ eq. de ácido graxo a partir de um triglicerídeo em 1 h com pH 7,2 a $37^{\circ} \mathrm{C}$.

4. Lipase de Candida cylindracea (CCL) 4,9 U/mg. Uma unidade corresponde à quantidade de enzima a qual libera $1 \mu \mathrm{mol}$ de ácido oléico por minuto com $\mathrm{pH} 8,0$ e $40^{\circ} \mathrm{C}$.

5. Lipase de Thermomyces lanuginosus (TLL) $\geq 3000 \mathrm{U} / \mathrm{g}$. Uma unidade corresponde à quantidade de enzima a qual libera $1 \mu \mathrm{mol}$ de ácido butírico por minuto com $\mathrm{pH} 7,5$ e $40^{\circ} \mathrm{C}$. 
6. Lipase de Aspergillus niger 200 U/g. Uma unidade corresponde à quantidade de enzima a qual libera $1 \mu \mathrm{mol}$ de ácido acético por minuto com $\mathrm{pH} 7,4$ e $40^{\circ} \mathrm{C}$.

7. Lipase de Rhizopus niveus $\geq 1,5 \mathrm{U} / \mathrm{mg}$. Uma unidade corresponde à quantidade de enzima a qual libera $1 \mu \mathrm{mol}$ de ácido graxo por minuto com $\mathrm{pH} 7,7$ e $40^{\circ} \mathrm{C}$.

8. Lipase de hog pancreas (HPL) 30,1 U/mg. Uma unidade corresponde à quantidade de enzima a qual libera $1 \mu \mathrm{mol}$ de ácido graxo a partir de triglicerídeos por minuto com $\mathrm{pH} 8,0$ e $37^{\circ} \mathrm{C}$ de óleo de oliva como substrato.

9. Lipase de Penicillium camemberti (PCL) $\geq 50 \mathrm{U} / \mathrm{mg}$. Uma unidade corresponde à quantidade de enzima a qual libera $1 \mu$ mol de ácido graxo a partir de triglicerídeos por minuto com $\mathrm{pH} 5,6$ e $40^{\circ} \mathrm{C}$.

10. Lipase Amano $\mathrm{AK} \geq 0,5 \mathrm{U} / \mathrm{mg}$. Uma unidade corresponde à quantidade de enzima a qual libera $1 \mu \mathrm{mol}$ de ácido butírico por minuto com $\mathrm{pH} 7,0$ e $25^{\circ} \mathrm{C}$.

As enzimas foram compradas das empresas Amano Europe, Fluka - Sigma (Steinheim, Germany) e da Sigma (Steinheim, Germany), exceto a CAL-B que foi doada pela NovoNordisk.

\subsubsection{Reagentes}

As aminas primárias foram adquiridas da empresa Aldrich, sendo que a ciclo-hexilamina foi adquirida da Fluka na proporção de 8:2 cis:trans.

Os reagentes e solventes utilizados foram obtidos comercialmente ou quando necessário purificados e/ou secos utilizando procedimentos descritos na literatura (Armarego \& Chai, 2009). As separações em colunas cromatográficas dos produtos foram realizados utilizando-se sílica gel 60 (400-230 mesh) e mistura de hexano/acetato de etila como eluentes.

\subsubsection{Equipamentos}

Os espectros de RMN ${ }^{1} \mathrm{H}$ e ${ }^{13} \mathrm{C}$ foram obtidos em um espectrômetro Bruker AC-200 $\left({ }^{1} \mathrm{H}\right.$ a $200 \mathrm{MHz}$ e ${ }^{13} \mathrm{C}$ a $\left.50 \mathrm{MHz}\right)$. Os espectros foram feitos em clorofórmio-d $\left(\mathrm{CDCl}_{3}\right)$ e os deslocamentos químicos ( $\delta$ ) são dados em ppm usando tetrametilsilano (TMS) como padrão interno de referência. 
As resoluções cinéticas enzimáticas foram realizadas utilizando-se um agitador orbital Tecnal TE-421 e um reator de irradiação micro-ondas CEM Discover 1 .

As reações enzimáticas foram analisadas utilizando um cromatógrafo Shimadzu GC 2010 equipado com um auto injetor AOC 20i, com um detector de ionização em chama (FID), e uma coluna J\&W Column DB-5 (30m x 0,25mm x $0,1 \mu)$, (5\%-fenil)-metilpolisiloxano) para a determinação das conversões e uma coluna Chirasil - DEX CB para determinação do excesso enantiomérico dos produtos acetilados.

\section{1.4 Procedimentos experimentais em escala analítica para as reações catalíticas}

Experimento I - Resolução enzimática de aminas

A resolução enzimática do experimento é descrita de acordo com a Figura 2.1

Figura 2.1: Resolução enzimática de aminas primárias com lipase

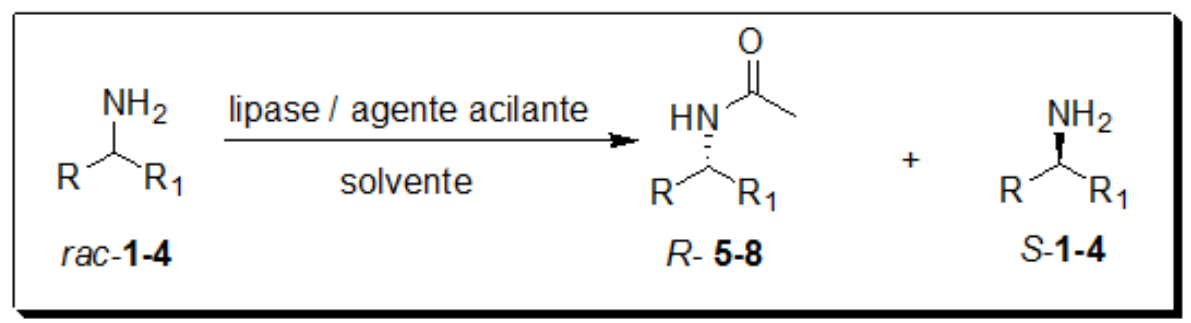

Em um tubo de ensaio de $10 \mathrm{~mL}$ foram adicionados hexano $(2 \mathrm{~mL})$, acetato de vinila $(0,1 \mathrm{~mL}-1 \mathrm{mmol})$ ou acetato de etila $(0,2 \mathrm{~mL}-2,5 \mathrm{mmol})$, as aminas 1-4 $(0,1 \mathrm{mmol})$ e a lipase (2 mg). A mistura reacional permaneceu sob agitação orbital de $130 \mathrm{rpm}$ a $30^{\circ} \mathrm{C}$ em diferentes tempos. Após a reação ser finalizada a enzima foi filtrada. Alíquotas das reações foram retiradas em diferentes tempos reacionais, posteriormente foram transferidas em vials e diluídas até $\sim$ 1,5 mL de AcOEt e analisadas por cromatografia a gás (CG-FID).

Experimento II - Resolução enzimática de aminas sob irradiação micro-ondas

A resolução enzimática de aminas sob irradiação de micro-ondas se dá segundo o esquema descrito na Figura 2.2

Em um balão de $5 \mathrm{~mL}$ foram adicionados hexano $(2 \mathrm{~mL})$, acetato de vinila $(0,1 \mathrm{~mL}-1 \mathrm{mmol})$ ou acetato de etila $(0,2 \mathrm{~mL}-2,5 \mathrm{mmol})$, as aminas $\mathbf{1 - 4}(0,1$ mmol) e lipase $(2 \mathrm{mg})$. A mistura reacional permaneceu sob agitação mecânica e irradiação micro-ondas a $70^{\circ} \mathrm{C}$ pelo tempo de 15 minutos. A reação foi 
Figura 2.2: Resolução enzimática de aminas primárias sob efeito da irradiação $\mathrm{MO}$

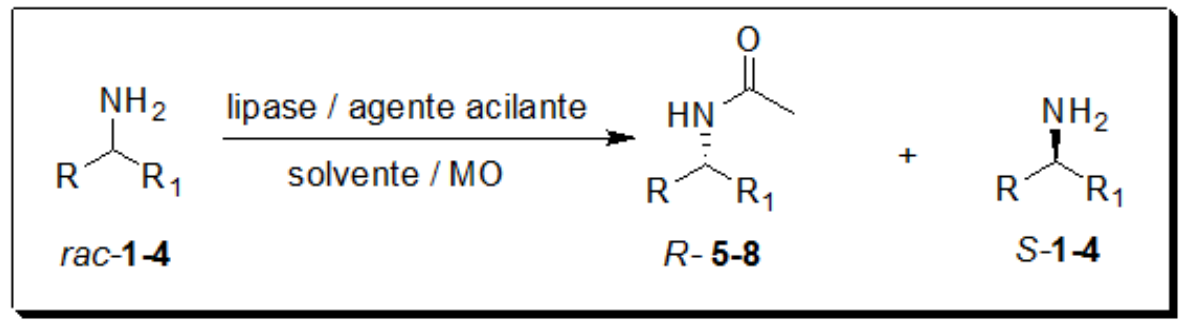

interrompida filtrando-se as enzimas. As amostras em diferentes tempos reacionais foram transferidas para frascos vials, diluídas com $\sim 1,5 \mathrm{~mL}$ de acetato de etila e posteriormente analisadas por CG-FID.

\subsubsection{Procedimentos experimentais em escala quantitativa}

Experimento I - Resolução enzimática de aminas

Em um Erlenmeyer de $50 \mathrm{~mL}$ foram adicionados hexano $(10 \mathrm{~mL})$, acetato de etila ( $2 \mathrm{~mL}-25 \mathrm{mmol})$, as aminas 1-4 (1 mmol) e CAL-B $(20 \mathrm{mg})$. A mistura reacional permaneceu sob agitação orbital de $130 \mathrm{rpm}$ a $30^{\circ} \mathrm{C}$ em diferentes tempos. A reação foi cessada filtrando-se a enzima e o hexano foi rotaevaporado. O produto foi purificado em coluna cromatográfica de sílica gel com eluente consistindo de hexano e acetato de etila. O excesso enantiomérico foi obtido após análise em CG-FID com coluna quiral Chirasil - DEX CB e a conversão da reação foi determinada em coluna capilar de sílica fundida DB-5.

Experimento II - Resolução enzimática de aminas sob irradiação micro-ondas

Em um balão de $50 \mathrm{~mL}$ foram adicionados hexano $(10 \mathrm{~mL})$, acetato de etila ( $2 \mathrm{~mL}$ - $25 \mathrm{mmol})$, as aminas 1-4 $(1 \mathrm{mmol})$ e CAL-B $(20 \mathrm{mg})$. A mistura reacional permaneceu sob agitação mecânica e irradiação de micro-ondas a $70^{\circ} \mathrm{C}$ pelo tempo de $15 \mathrm{~min}$. A reação foi cessada filtrando-se a enzima e o hexano foi rotaevaporado. O produto foi purificado em coluna cromatográfica de sílica gel com eluente consistindo de hexano e acetato de etila. O excesso enantiomérico foi determinado após análise em CG-FID com coluna quiral Chirasil - DEX CB e a conversão da reação também foi determinada em coluna capilar DB-5. 


\subsubsection{Dados espectroscópicos e cromatográficos}

(+)-(R)-N-( 1-metil-hexil)acetamida (4)

: $[\alpha]_{D}{ }^{25}+0.094^{\circ}(c 1.00, \mathrm{MeOH}) \cdot \mathrm{RMN}^{1} \mathrm{H}\left(200 \mathrm{MHz}, \mathrm{CDCl}_{3}\right), \delta(\mathrm{ppm}): 6,01$ (s, $\mathrm{NH}) ; 3,84(\mathrm{~m}, 1 \mathrm{H}) ; 1,86(\mathrm{~s}, 3 \mathrm{H}) ; 1,18(\mathrm{~m}, 7 \mathrm{H}) ; 1,01(\mathrm{~d}, J=6,7,2 \mathrm{H}) ; 0,91(\mathrm{~m}$, $1 \mathrm{H}) ; 0,76$ (t, 3H). Os dados espectroscópicos estão de acordo com a literatura (Narayanan \& Sawant, 1971; Chalard et al., 2000). RMN ${ }^{13} \mathrm{C}\left(50 \mathrm{MHz}, \mathrm{CDCl}_{3}\right.$ ), $\delta(\mathrm{ppm}): 169,4 ; 45,0 ; 36,6 ; 31,5 ; 25,5 ; 23,1 ; 22,3 ; 20,6 ; 13,8$. A mistura de eluente para coluna cromatográfica foi hexano/acetato de etila $(5 / 6 ; \mathrm{v} / \mathrm{v})$. As condições empregadas nas análises de cromatografia a gás foram as seguintes: coluna capilar DB-5; gás de arraste: nitrogênio (74,6 kPa); temperatura do injetor: $250^{\circ} \mathrm{C}$; razão de split do injetor: 1:20; temperatura do detector: $250^{\circ} \mathrm{C}$; forno: $160^{\circ} \mathrm{C}$ por $10 \mathrm{~min}$.; tempo de análise: $10 \mathrm{~min}$. Tempo de retenção do composto $=5,06$ min. Coluna Chirasil - DEX CB; gás de arraste: nitrogênio $(69,2 \mathrm{kPa})$; temperatura do injetor: $250^{\circ} \mathrm{C}$; razão de split do injetor: 1:10; temperatura do detector: $250^{\circ} \mathrm{C}$; forno: $120^{\circ} \mathrm{C}$ por $17,0 \mathrm{~min}$.; tempo de análise: 17,0 min. Tempo de retenção do composto $4=R \mathbf{4} 11,65$ e $R \mathbf{4} 12,76$ min. Rendimento isolado $=70 \%$ (Figura 2.3 e 2.4).

Figura 2.3: Cromatograma da $N$-(1-metil-hexil)acetamida) (4) em cromatografia a gás com coluna DB-5

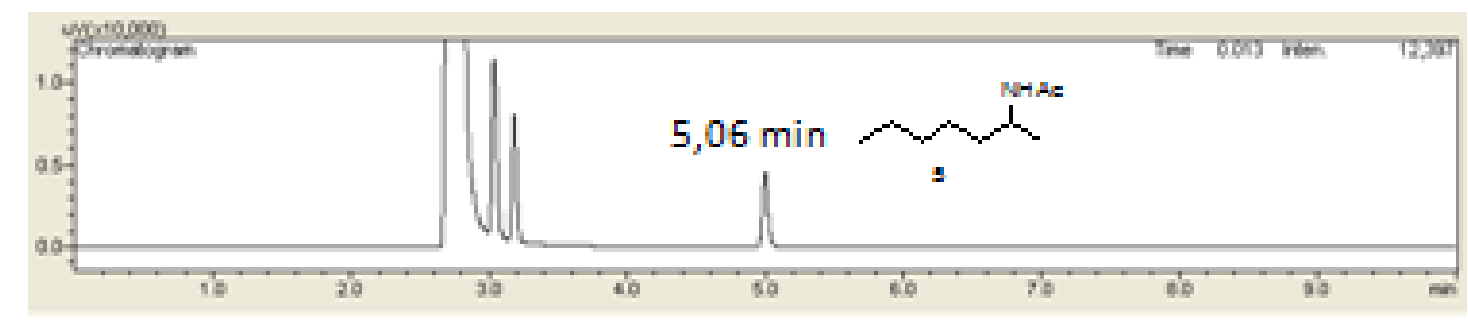

Figura 2.4: Cromatograma da $N$-(1-metil-hexil)acetamida (4) em cromatografia a gás com coluna Chirasil - DEX CB

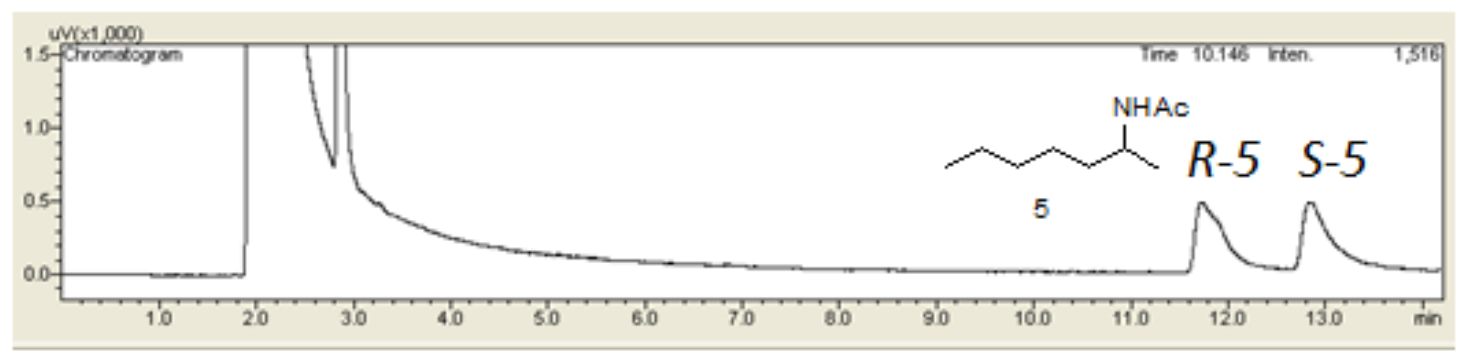


cis-(R)-N-(2-metilciclo-hexil)acetamida (8):

RMN)textsuperscript1H (200MHz, $\mathrm{CDCl}_{3}$ ), $\delta(\mathrm{ppm}): 8,73$ (s, NH); 6,61-6,46 (m, 1H); 3,88-3, 17 (m, 1H); 1,88 (s, 3H); 1,83-0,95 (m, 8H); 0,72 (t, J=6,7, $3 \mathrm{H}) . \mathrm{RMN}^{13} \mathrm{C}\left(50 \mathrm{MHz}, \mathrm{CDCl}_{3}\right), \delta(\mathrm{ppm}): 174,6 ; 54,1 ; 37,5 ; 33,9 ; 32,9 ; 25,3$; 25,$0 ; 20,6 ; 18,7$. Os dados espectroscópicos estão de acordo com a literatura (Laurent et al., 1972). A mistura de eluente para coluna cromatográfica foi hexano/acetato de etila (5/6 v/v). As condições empregadas nas análises de cromatografia a gás foram as seguintes: Coluna DB-5; gás de arraste: nitrogênio $(55,1 \mathrm{kPa})$; temperatura do injetor: $250^{\circ} \mathrm{C}$; razão de split do injetor: 1:10; temperatura do detector: $250^{\circ} \mathrm{C}$; forno: $120^{\circ} \mathrm{C}$ por $35 \mathrm{~min}$; t tempo de análise: $35 \mathrm{~min}$. Tempo de retenção do composto 8 = cis-8 7,82 min e trans-8 7,98 min. Rendimento isolado $=67 \%$ (Figura 2.5).

Figura 2.5: Cromatograma da $N$-(2-metil-ciclo-hexil) acetamida (8) por cromatografia a gás com coluna DB-5

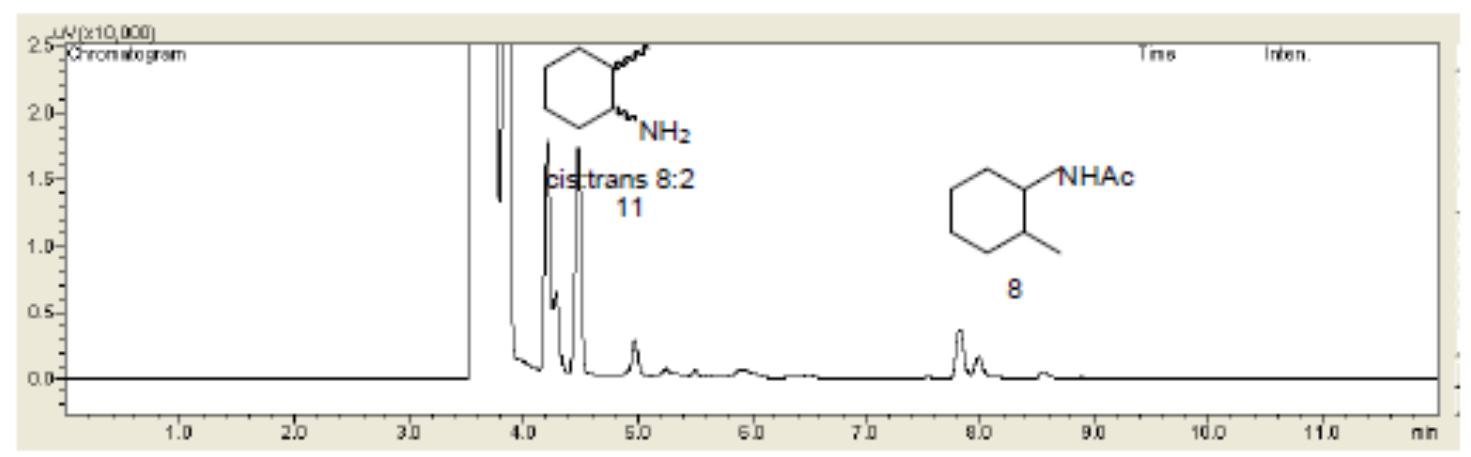

(+)-(R)-N-( 7-metill-3-fenil propil)acetamida (6):

$[\alpha]_{D}{ }^{25}+0.248^{\circ}$ (c 1.00, EtOH); $\mathrm{RMN}^{1} \mathrm{H}\left(200 \mathrm{MHz}, \mathrm{CDCl}_{3}\right), \delta(\mathrm{ppm}): 7,32-7,16$ $\mathrm{m}, 5 \mathrm{H}) ; 5,83$ (s, NH); 4, 12-3,98 (m, 1H); 2,70-2,72 (m, 2H); 1,98 (s, 3H); 1,84$1,73(\mathrm{~m}, 2 \mathrm{H}) ; 1,17$ (d, J=6,4, 3H). $\mathrm{RMN}^{13} \mathrm{C}\left(50 \mathrm{MHz}, \mathrm{CDCl}_{3}\right), \delta(\mathrm{ppm}): 169,7$; 141,$6 ; 128,4 ; 128,3 ; 125,9 ; 45,4 ; 38,4 ; 32,5 ; 23,3 ; 21,0$. Os dados espectroscópicos estão de acordo com a literatura (Kim et al., 2007). A mistura de eluente para coluna cromatográfica foi hexano/acetato de etila (5/6, v/v). As condições empregadas nas análises por cromatografia a gás foram as seguintes: Coluna DB-5; gás de arraste: nitrogênio (100 kPa); temperatura do injetor: $250^{\circ} \mathrm{C}$; razão de split do injetor: $1: 20$; temperatura do detector: $250^{\circ} \mathrm{C}$; forno: (temperatura inicial) $70^{\circ} \mathrm{C}$, (temperatura final) $210^{\circ} \mathrm{C}$ por $1 \mathrm{~min}$.; taxa de aquecimento: $10^{\circ} \mathrm{C} / \mathrm{min}$.; tempo de análise: $15 \mathrm{~min}$. Tempo de retenção do composto 6 = $14 \mathrm{~min}$. Coluna Chirasil - DEX CB; gás de arraste: nitrogênio $(87,9 \mathrm{kPa})$; temperatura do injetor: $250^{\circ} \mathrm{C}$; razão de split do injetor: $1: 10$; 
temperatura do detector: $250^{\circ} \mathrm{C}$; forno: $150^{\circ} \mathrm{C}-170^{\circ} \mathrm{C}$ a $1^{\circ} \mathrm{C} / \mathrm{min}$.; tempo de análise: 20 min. Tempo de retenção do composto $\mathbf{6}=R \mathbf{6}$ 13,8 e $\mathbf{S} \mathbf{6 1 4 , 2} \mathrm{min}$. Rendimento isolado $=78 \%$ (Figuras 2.6 e 2.7).

Figura 2.6: Cromatograma da $N$-(1-metil-3-fenilpropil) acetamida (6) e a amida (2) por cromatografia a gás com coluna DB-5

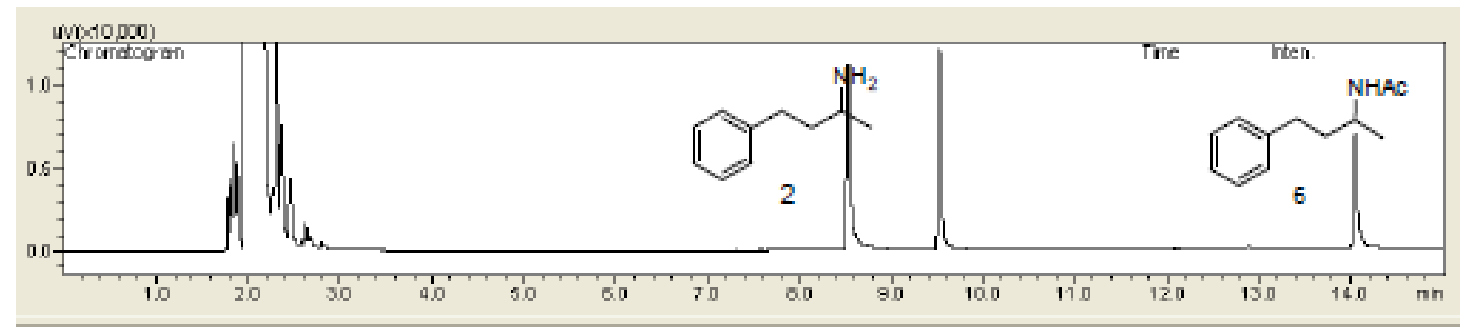

Figura 2.7: Cromatograma da $N$-(1-metil-3-fenilpropil) acetamida (6) por cromatografia a gás com coluna Chirasil - DEX CB

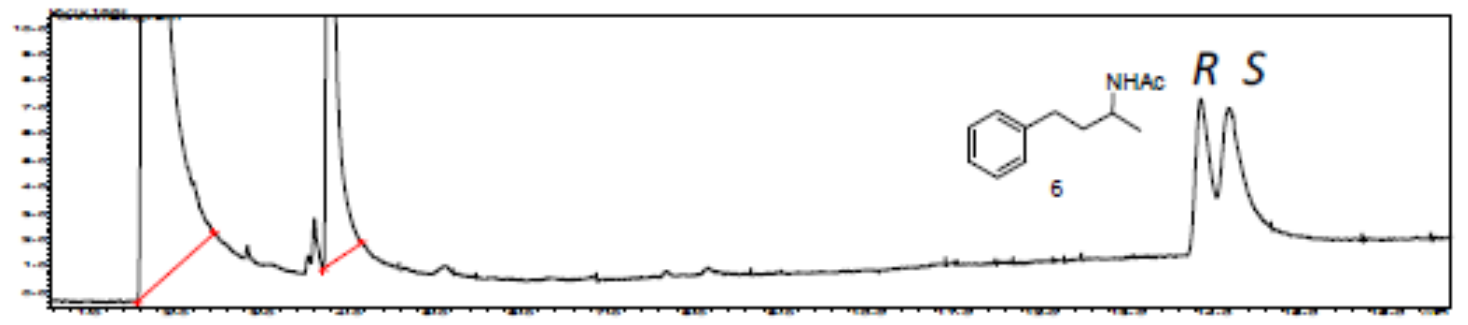

(+)-(R)-N-( 1,2,3,4-tetra-hidronaftaleno) acetamida (7):

$[\alpha]_{D}{ }^{25}+1.010^{\circ}$ (c 1.00, CHCl3; $\mathrm{RMN}^{1} \mathrm{H}\left(200 \mathrm{MHz}, \mathrm{CDCl}_{3}\right), \delta(\mathrm{ppm}): 7,26-7,10$ (m, 4H); 5,90 (s, NH); 5,19 (sl, 1H); 2,79 (sl, 2H); 2,35 (s, 1H); 2,04 (s,3H); 1,83 (sl, 3H). RMN ${ }^{13} \mathrm{C}\left(50 \mathrm{MHz}, \mathrm{CDCl}_{3}\right), \delta(\mathrm{ppm}): 169,5 ; 137,6 ; 136,4 ; 129,2$; 128,$7 ; 127,4 ; 126,3 ; 47,6 ; 30,0 ; 29,2 ; 23,4 ; 19,8$. Os dados espectroscópicos estão de acordo com a literatura (Kim et al., 2007). O Eluente para coluna cromatográfica foi hexano/acetato de etila $(7 / 3, \mathrm{v} / \mathrm{v})$. As condições empregadas nas análises de cromatografia a gás foram as seguintes: Coluna DB-5; gás de arraste: nitrogênio $(60 \mathrm{kPa})$; temperatura do injetor: $250^{\circ} \mathrm{C}$; razão de split do injetor: 1:10; temperatura do detector: $250^{\circ} \mathrm{C}$; forno: $180^{\circ} \mathrm{C}$ por $15 \mathrm{~min}$.; tempo de análise: $15 \mathrm{~min}$. Tempo de retenção do composto $7=14,04 \mathrm{~min}$. Coluna Chirasil - DEX CB; gás de arraste: nitrogênio (143 kPa); temperatura do injetor: $250^{\circ} \mathrm{C}$; razão de split do injetor: $1: 10$; temperatura do detector: $250^{\circ} \mathrm{C}$; forno: $200^{\circ} \mathrm{C}$ por $16 \mathrm{~min}$. Tempo de análise: $16 \mathrm{~min}$. Tempo de retenção do composto $\mathbf{7}=R-\mathbf{7} 13,64 \mathrm{~min}$ e $\mathbf{S - 7} 13,95 \mathrm{~min}$. Rendimento isolado $=$ 75\% (Figuras 2.8 e 2.9). 
Figura 2.8: Cromatograma da $N$-(1,2,3,4-tetra-hidronaftaleno) acetamida (7) e da amina 3 em cromatografia a gás com coluna DB-5

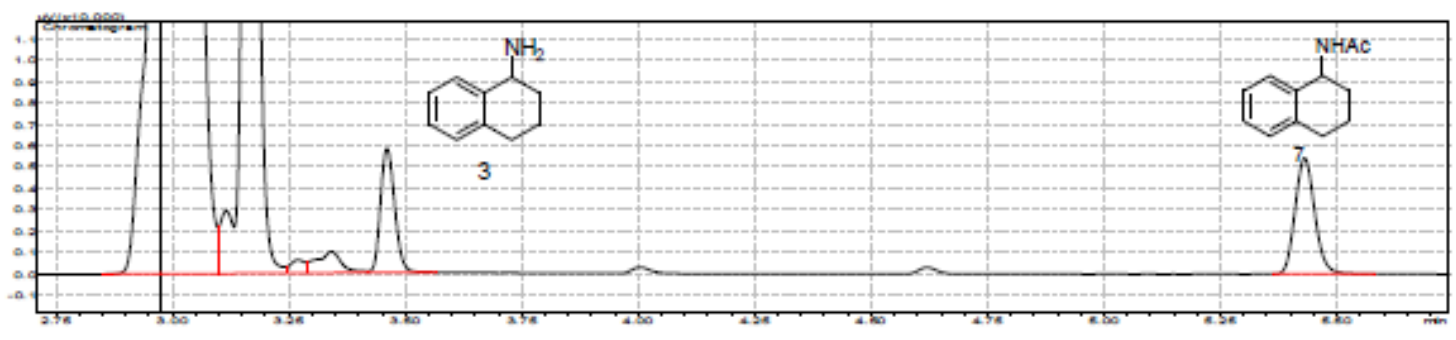

Figura 2.9: Cromatograma da $N$-(1,2,3,4-tetra-hidronaftaleno) acetamida (7) em cromatografia a gás com coluna Chirasil - DEX CB

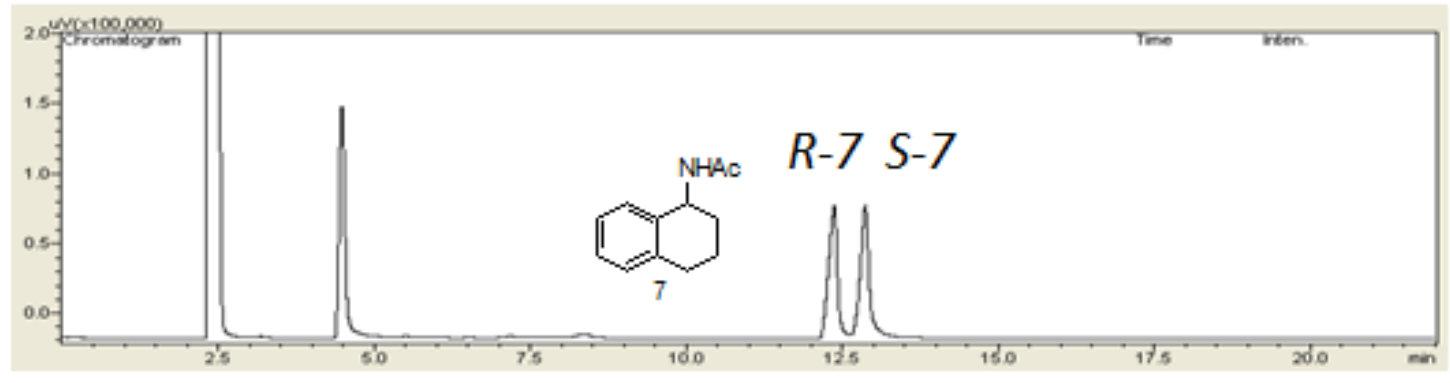




\subsection{Resultados e Discussão}

A amina primária racêmica 2-amino-heptano (1) foi submetida à acetilação enzimática catalisada por lipase de Candida antarctica (CAL-B) utilizando-se dois agentes acilantes (acetato de vinila e acetato de etila) e cinco solventes (hexano, acetato de etila, éter isopropílico, tolueno, tetraidrofurano), com o intuito de se estabelecer as melhores condições reacionais.

Na Tabela 2.1 pode-se observar que a reação que ocorreu na presença de acetato de etila (agente acilante) e em hexano resultou em uma conversão de $42 \%$ e uma pureza enantiomérica de $88 \%$ para o produto acetilado $R-\mathbf{5}$, demonstrando serem as condições reacionais de maior interesse obtidas nestes estudos.

Os resultados com relação ao solvente estão de acordo com a literatura (Zaks \& Klibanov, 1988), pois as lipases apresentam maior atividade em solventes hidrofóbicos onde as moléculas de água residuais presentes no solvente orgânico ficam disponíveis para a re-hidratação da enzima, o que gera uma maior mobilidade conformacional da mesma aumentando sua eficiência catalítica.

As reações com o acetato de etila, éter isopropílico, tolueno e THF frente ao agente acilante acetato de vinila, embora promoveram uma boa conversão em todas as reações (c=40-56\%), praticamente não levaram à formação de produtos com seletividade (Tabela 2.1 ). 
Tabela 2.1: Resolução enzimática de 2-amino-heptano (1) catalisada pela lipase CAL-B

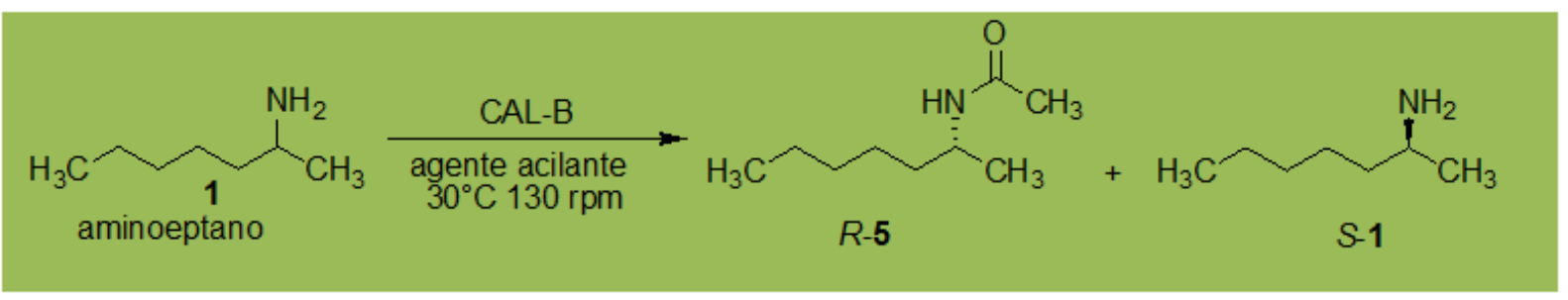

\begin{tabular}{|c|c|c|c|c|c|c|}
\hline \multirow[t]{3}{*}{ Solventes } & \multicolumn{6}{|c|}{ Agente Acilante } \\
\hline & \multicolumn{3}{|c|}{ Acetato de vinila } & \multicolumn{3}{|c|}{ Acetato de Etila } \\
\hline & Tempo (h) & $e e_{\mathrm{p}}{ }^{\mathrm{a}}(\%)$ & $c^{b}(\%)$ & Tempo (h) & $e e_{\mathrm{p}}{ }^{\mathrm{a}}(\%)$ & $c^{b}(\%)$ \\
\hline Hexano & 1 & 0,3 & 51 & 7 & 88 & 42 \\
\hline Acetato de Etila & 6 & 2,1 & 51 & 60 & $\mathrm{Nr}$ & $\mathrm{Nr}$ \\
\hline Éter Isopropílico & 10 & 12 & 40 & 7 & 81 & 52 \\
\hline Tolueno & 6 & 5 & 48 & 10 & 65 & 40 \\
\hline THF & 9 & 0,6 & 56 & 24 & 0 & 0 \\
\hline
\end{tabular}

${ }^{\mathrm{a}} e e_{p}=$ excesso enantiomérico do produto (determinado por CG-FID, coluna CHIRASIL-DEX CB).

${ }^{\mathrm{b}} \mathrm{c}=$ conversão determinada por CG-FID (coluna DB-5).

c condições reacionais: solvente (2 mL), CAL-B (1,5 mg), 2-amino-heptano (0,4 mmol), agente acilante $(1 \mathrm{mmol})$, agitação orbital $\left(130 \mathrm{rpm}, 30^{\circ} \mathrm{C}\right)$.

$\mathrm{Nr}=$ não reagiu.

Não foi possivel recuperar a amina remanecente.

De acordo com os resultados anteriores, ampliaram-se os estudos utilizandose as aminas primárias racêmicas 1-4 frente a uma triagem com 11 lipases, especificadas na Tabela 2.2, na presença de acetato de vinila como agente acilante e hexano como solvente. A Tabela 2.2 apresenta os resultados obtidos, onde se pode observar que todas as lipases renderam boas conversões, porém com baixos valores de excessos enantioméricos frente aos produtos $(e e<$ $14 \%)$.

Ainda em relação às condições experimentais, com o objetivo de buscar um melhor desempenho nestas reações, a reação enzimática foi realizada nas temperaturas de 30 e $60^{\circ} \mathrm{C}$, utilizando a lipase CAL-B como catalisador, acetato de etila como agente acilante, a amina 2 como substrato em 5 diferentes solventes (hexano, acetato de etila, éter isopropílico, tolueno e THF) (Tabela 2.3). Na temperatura de $60^{\circ} \mathrm{C}$ foi observado que o tempo reacional para se obter uma conversão de $\sim 20 \%$ é 2,5 vezes menor que a $30^{\circ} \mathrm{C}$, porém os ee's decresceram acentuadamente. Enquanto que na temperatura de $30^{\circ} \mathrm{C}$, a reação apresentou melhores valores de conversão e excesso enantiomérico, por exemplo, em éter isopropílico, tolueno e hexano foram obtidos uma pureza 
Tabela 2.2: Resolução enzimática das aminas (1-4) catalisada por diferentes lipases comerciais

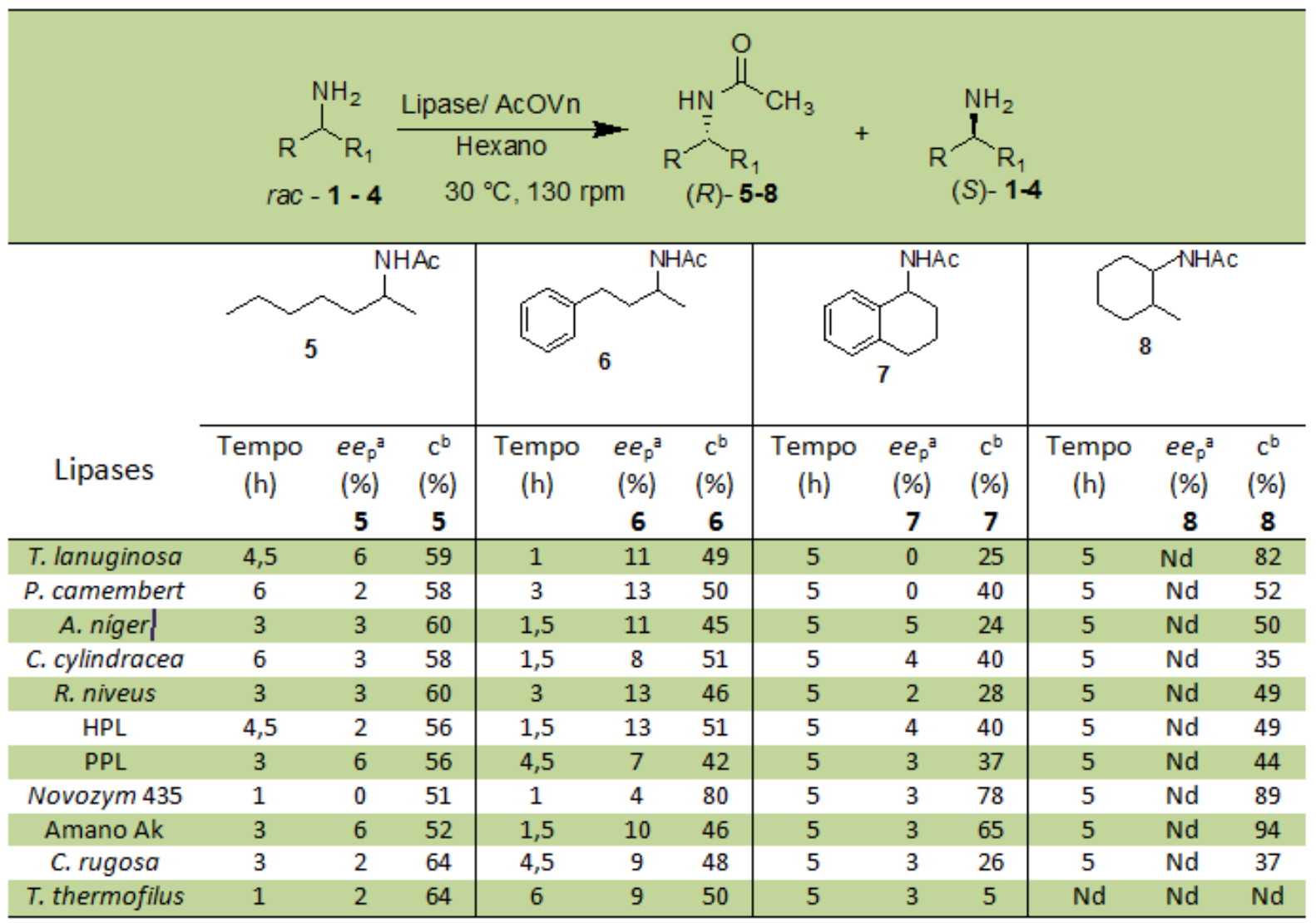

a $e e_{p}=$ excesso enantiomérico do produto (determinado por CG, coluna CHIRASIL-DEX CB).

${ }^{\mathrm{b}} \mathrm{c}=$ conversão determinada por CG (coluna DB-5).

${ }^{c}$ condições reacionais: Hexano $(2 \mathrm{~mL})$, lipase $(1,5 \mathrm{mg})$, amina $(0,4 \mathrm{mmol})$, acetato de vinila $(0,1 \mathrm{~mL}, 1 \mathrm{mmol})$, agitação orbital $\left(130 \mathrm{rpm}, 30^{\circ} \mathrm{C}\right)$.

$\mathrm{Nd}=$ não determinado.

Não foi possível recuperar a amina remanecente.

enantiomérica $>99 \%$ e conversão de $15-22 \%$.

O decréscimo do excesso enantiomérico pode ter ocorrido devido ao fato de que o aumento da temperatura favorece um aumento na mobilidade molecular alterando a conformação da lipase e do centro catalítico, resultando numa maior liberdade espacial para o substrato, assim como, um acesso mais fácil ao sítio ativo. Assim, o enantiômero que reage de forma mais lenta torna-se menos impedido estericamente levando a um decréscimo na enantiosseletividade da reação com o aumento da temperatura (Berendsen et al., 2006). 
Tabela 2.3: Resolução enzimática da 1-metil-3-fenilpropilamina (2) com lipase CAL-B

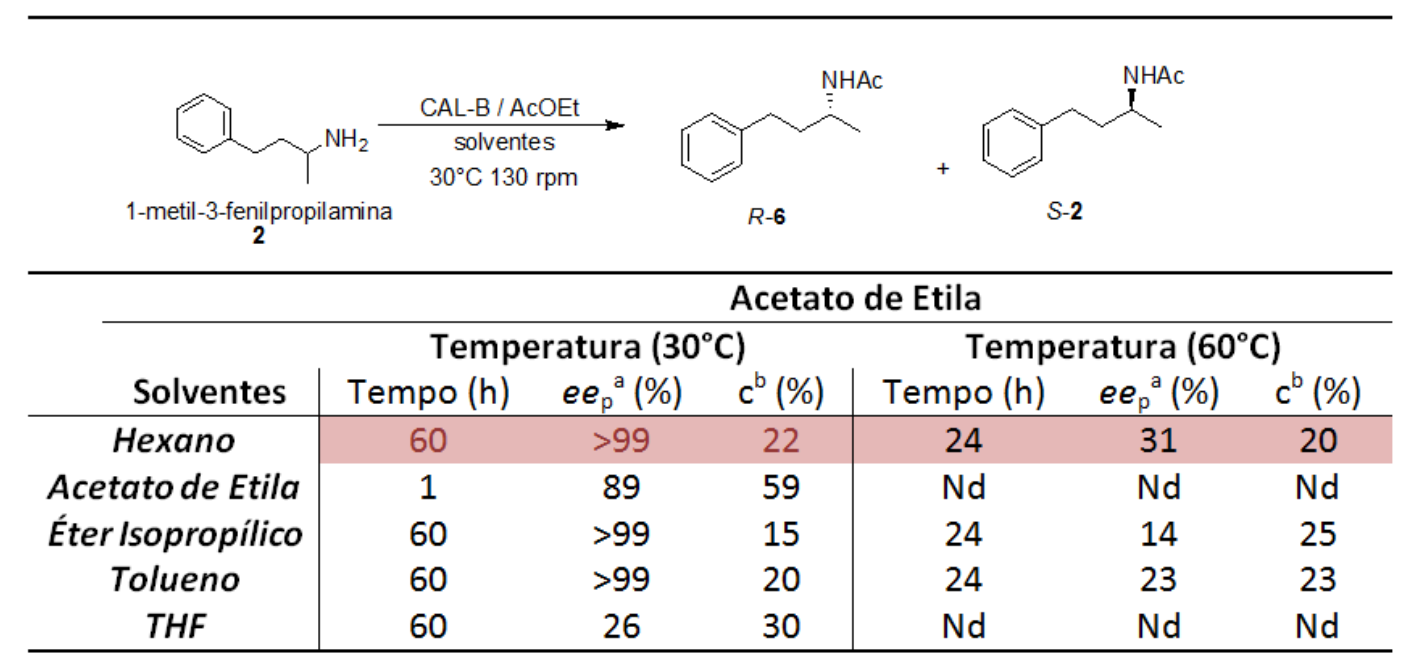

a $e e_{p}=$ excesso enantiomérico do produto (determinado por CG-FID, coluna CHIRASIL-DEX CB).

${ }^{\mathrm{b}} \mathrm{c}=$ conversão determinada por CG-FID (coluna DB-5).

c condições reacionais: solvente $(2 \mathrm{~mL})$, CAL-B (1,5 mg), 1-metil-3fenilpropilamina $(0,4 \mathrm{mmol})$, acetato de etila $(0,2 \mathrm{~mL}, 2,5 \mathrm{mmol})$, agitação orbital (130 rpm, $\left.30^{\circ} \mathrm{C}\right)$.

$\mathrm{Nd}=$ não determinado.

Não foi possível recuperar a amina remanecente.

Foi também realizado um experimento para verificar a influência da quantidade de enzima utilizada, comparando uma reação de resolução enzimática com $2 \mathrm{mg}$ de enzima e outra com uma quantidade 10 vezes maior da mesma (20 mg) para a amina rac-3.

Na Tabela 2.4 observa-se que as lipases de A. niger, C. cylindracea, pâncreas suíno e Novozym 435 (CAL-B) apresentaram uma redução no tempo reacional de 7 dias para 1 ou 2 dias para atingir a mesma conversão nos produtos, enquanto a lipase de pâncreas suíno promoveu um aumento significativo na conversão que foi de $4 \%$ em 7 dias para $68 \%$ em apenas um dia de reação. 
Tabela 2.4: Resolução enzimática de 1,2,3,4-tetra-hidro-1-naftilamina (3) catalisada por diferentes lipases

\begin{tabular}{|c|c|c|c|c|}
\hline 1,2,3,4-tetra hidrc & $\begin{array}{l}\text { lipase / AcOEt } \\
\begin{array}{l}\text { Hexano } \\
30^{\circ} \mathrm{C} 130 \mathrm{rpm}\end{array} \\
\text { naftilamina }\end{array}$ & $R-7$ & $S-4$ & \\
\hline \multirow[b]{2}{*}{ Lipases } & \multicolumn{2}{|c|}{$2 \mathrm{mg}$ de lipases } & \multicolumn{2}{|c|}{$20 \mathrm{mg}$ de lipases } \\
\hline & Tempo (Dias) & $\begin{array}{c}c^{\mathrm{a}}(\%) \\
8\end{array}$ & Tempo (Dias) & $\begin{array}{c}c^{\mathrm{a}}(\%) \\
8\end{array}$ \\
\hline T. lanuginosa & 7 & 3 & 7 & 2 \\
\hline P. camemberti & 7 & 1 & 7 & 3 \\
\hline A. niger & 7 & 2 & 2 & 2 \\
\hline C. cylindracea & 7 & 2 & 1 & 2 \\
\hline R. niveus & 7 & 2 & 7 & 8 \\
\hline Hog Pâncreas & 7 & 5 & 7 & 4 \\
\hline Porcine Pancreatic & 7 & 4 & 1 & 68 \\
\hline CAL-B & 7 & 7 & 1 & 5 \\
\hline Amano Ak & 7 & 6 & 7 & 7 \\
\hline C. rugosa & 7 & 3 & 7 & 2 \\
\hline
\end{tabular}

${ }^{\mathrm{a}} \mathrm{c}=$ conversão determinada por CG-FID (coluna DB-5).

b condições reacionais: hexano $(2 \mathrm{~mL})$, lipase $(2 \mathrm{mg}$ ou $20 \mathrm{mg}),( \pm)-1,2,3,4$ tetra-hidro-1-naftil amina $(0,4 \mathrm{mmol})$, acetato de etila $(0,2 \mathrm{~mL}, 2,5 \mathrm{mmol})$, agitação orbital $\left(130 \mathrm{rpm}, 30^{\circ} \mathrm{C}\right)$.

Finalizando esta etapa do estudo, 5 lipases foram selecionadas (T. lanuginosa, P. camembert, C. cylindracea, HPL e CAL-B) e utilizadas na resolução cinética enzimática das aminas primárias 1-4 com acetato de etila (agente acilante) em hexano (solvente) por $7 \mathrm{~h}$.

Na Tabela 2.5 constatou-se que a lipase de CAL-B resultou no melhor valor de ee para amidas 5, 6 e 8 (ee=71, 69 e 65\%) respectivamente e na melhor conversão para as amidas 6 e 8 (c=24 e 6\%) respectivamente. Quando utilizou a amina 1 a melhor conversão ocorreu na presença de C. cylindracea $(\mathrm{c}=32 \%)$ com ee de 3\%. Por fim, a amina 3 apresentou o melhor ee (11\%) e conversão de $2 \%$ quando a enzima foi a HPL. 
Tabela 2.5: Resolução enzimática das aminas (1-4) catalisada por diferentes lipases comerciais utilizando acetato de etila como agente acilante

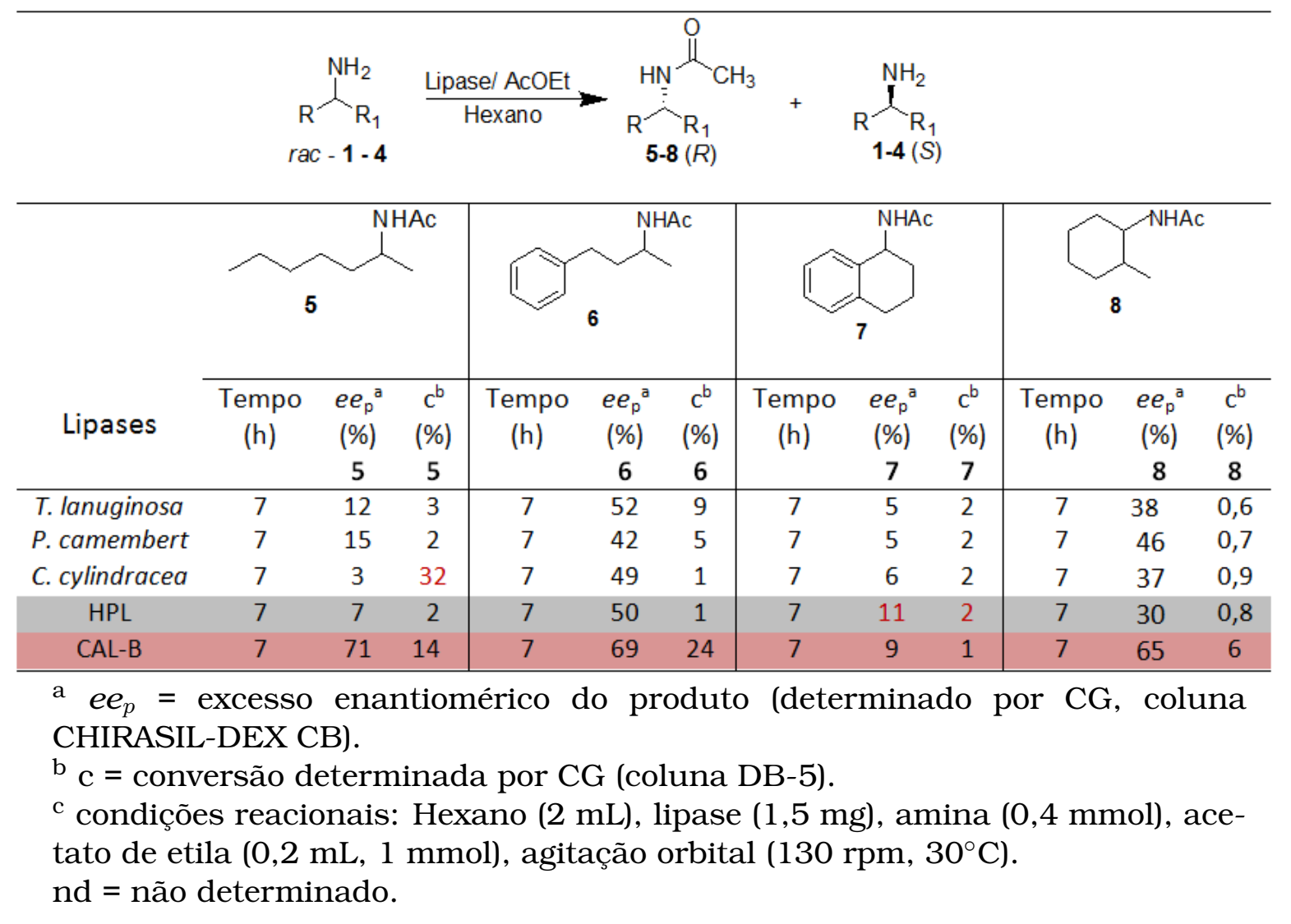

Quando comparou-se os resultados obtidos nas reações onde o agente acilante foi o acetato de vinila com os resultados da Tabela 2.5, nos quais o agente acilante foi o acetato de etila, foi possível observar que o acetato de etila sucede em melhores ee's, porém com valores de conversão inferiores em tempos semelhantes. Para nucleófilos fortes (aminas) o acetato de etila é o melhor agente acilante, no caso de álcoois o acetato de vinila é o melhor acilante.

Ésteres ativados, tais como o acetato de vinila ou acetato de 4-clorofenila, têm sido utilizados como dadores de acila em resolução cinética de álcoois (Kirilin et al., 2010; Hirata et al., 2007; Jung et al., 2000). Os ésteres ativados, ou seja, aqueles que contêm grupos insaturados ou grupos funcionais eletronegativos, são conhecidos por reagir mais rapidamente do que o acetato de etila como um doador de acila (Jung et al., 2000). Isto ocorre porque a velocidade da reação torna-se mais elevada quando a acilação é irreversível. Por exemplo, a resolução cinética com acetato de vinila é irreversível, pois um produto instável, o álcool vinílico, é formado em quantidades estequiométricas e rapidamente reage para formar acetaldeído via tautomerização ceto-enólica (Hirata et al., 2007). Guando um grupo acil doador saturado, tal como ace- 
tato de etila, é utilizado, o etanol é formado como um subproduto e a reação é reversível. O equilíbrio pode ser deslocado para o éster desejado utilizando um excesso de doador de acila. A velocidade de reação é, contudo, bastante lenta em acetato de etila (Verzijl et al., 2005), e o etanol diminui ainda mais a velocidade da reação, aumentando a hidrofobicidade da mistura reacional (Jung et al., 2000). Também o acetato de etila pode liberar ácido acético e causar inibição da enzima.

Devido à importância da Química Verde, com o objetivo de desenvolver reações de forma sustentável e o interesse em resoluções cinéticas com menor tempo reacional, foi investigada a resolução cinética enzimática de aminas primárias em reator de micro-ondas. Nestes estudos foram utilizadas as aminas quirais 1-4, hexano como solvente e como agente acilante os acetatos de vinila e etila. As condições no micro-ondas foram de $70^{\circ} \mathrm{C}$ e 15 minutos de reação. Os resultados obtidos são descritos na Tabela 2.6.

Tabela 2.6: Resolução enzimática das aminas (1-4) na presença de irradiação micro-ondas

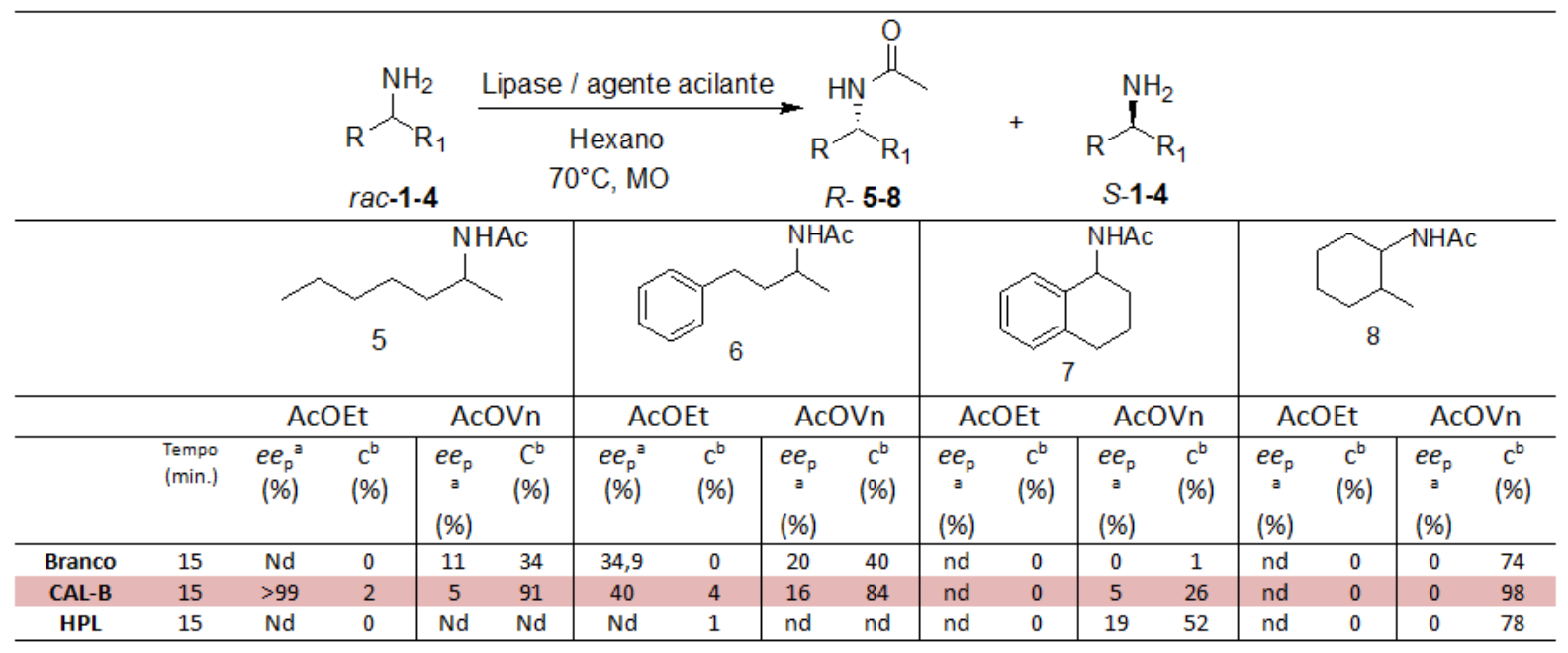

a $e e_{p}=$ excesso enantiomérico do produto (determinado por CG-FID, coluna CHIRASIL-DEX CB).

${ }^{\mathrm{b}} \mathrm{c}=$ conversão determinada por CG-FID (coluna DB-5).

${ }^{c}$ condições reacionais: hexano $(2 \mathrm{~mL})$, lipase $(1,5 \mathrm{mg}$ ou $20 \mathrm{mg})$, amina $(0,4$ mmol), agente acilante $(0,2 \mathrm{~mL}, 2,5 \mathrm{mmol}$ para o AcOEt ou $0,1 \mathrm{~mL}, 1 \mathrm{mmol}$ para o AcOVn), agitação orbital (130 rpm, $\left.30^{\circ} \mathrm{C}\right)$.

$\mathrm{Nd}=$ não determinado

Quando se utilizou o acetato de etila como agente acilante foi possível observar que a reação não ocorreu na ausência de lipase (branco) e que a lipase de Hog pâncreas (HPL) não demonstrou atividade catalítica significante. A lipase de CAL-B (Novozym 435) demonstrou uma baixa conversão para a 2- 
amino-heptano (1) (c = 2\%, ee $>99 \%$ ) e para a fenilpropilamina (2) foi obtida uma conversão de $4 \%$ e ee de $40 \%$.

Quando a reação foi realizada com CAL-B e HPL na presença de acetato de vinila, a acetilação ocorreu sem a presença da lipase (amida 5, c=34\%, amida 6, c= 40\%, amida 7, c= 1\%, amida 8, c= 74\%), demonstrando que somente a irradiação micro-ondas favoreceu a formação de produtos, pois quando a mesma foi realizada no agitador orbital sem a presença da irradiação microondas não foi observada a formação de produtos. Na presença de CAL-B a conversão foi aumentada, porém sem a formação de produtos enantioméricos significativos (amida 5, c= 91\%, ee= 5\%; amida 6, c= 84\%, ee= 16\%; amida 7, $\mathrm{c}=26 \%$, ee= 5; amida 8, c=98\%,ee=0\%). Com a lipase HPL foi possível observar uma maior atividade catalítica quando se utilizou a naftilamina 3.

A maior atividade catalítica apresentada pela lipase CAL-B em relação à lipase HPL pode ser atribuída pelo fato da CAL-B ser uma enzima imobilizada, o que confere uma maior estabilidade térmica (Nawani et al., 2006).

Os resultados obtidos para a resolução cinética enzimática assistida por irradiação micro-ondas estão de acordo com a literatura, pois a atividade da lipase aumenta sob o aquecimento de micro-ondas, devido ao aumento das colisões moleculares e uma redução na constante de inibição, existindo um sinergismo entre as micro-ondas e o meio na ação da lipase. As micro-ondas também aumentam a entropia do sistema e podem levar a um aumento na afinidade entre o substrato e o sítio ativo da lipase (Yadav \& Borkar, 2008). No entanto, há também estudos na literatura que demonstram que muitas reações não são favorecidas na presença da irradiação micro-ondas (Souza et al., 2009).

Os baixos excessos enantioméricos obtidos podem ser atribuídos também por esse aumento na afinidade do substrato pelo sítio ativo, pois isso ocorre para os dois enantiômeros reduzindo a seletividade das lipases.

Para finalização dos estudos a resolução cinética enzimática com acetato de etila foram analisadas. As reações com a lipase CAL-B em hexano e com acetato de etila como agente acilante foram realizadas para as aminas 1-4 uma única vez para o isolamento dos produtos formados e cálculo dos rendimentos. A determinação da configuração absoluta foi atribuída comparando-se os resultados de rotação óptica com aqueles descritos na literatura (Tabela 2.7). 
Tabela 2.7: Valores de rotação óptica dos produtos obtidos por resolução enzimática e da literatura

\begin{tabular}{|c|c|c|c|c|c|c|c|c|}
\hline & \multicolumn{4}{|c|}{ Experimental } & \multicolumn{4}{|c|}{ Literatura } \\
\hline & $\begin{array}{c}\text { Rendimento } \\
(\%)\end{array}$ & {$[\alpha]_{0}{ }^{25}$} & Solvente & $\begin{array}{c}c \\
(\mathrm{mg} / \mathrm{mL})\end{array}$ & {$[\alpha]_{0}{ }^{25}$} & Solvente & $\begin{array}{c}c \\
(\mathrm{~g} / 100 \mathrm{~mL})\end{array}$ & Referência \\
\hline $\begin{array}{c}\text { Amina } \\
1\end{array}$ & nd & $\begin{array}{c}+0,010 \\
(S)\end{array}$ & $\mathrm{MeOH}$ & 1 & $\begin{array}{l}+0,4 \\
(S)\end{array}$ & $\mathrm{MeOH}$ & 1,6 & $\begin{array}{l}\text { NECHAB et } \\
\text { al., } 2007 .\end{array}$ \\
\hline $\begin{array}{c}\text { Amida } \\
5\end{array}$ & 70 & $\begin{array}{c}+0,094 \\
(R)\end{array}$ & $\mathrm{MeOH}$ & 1 & nd & nd & nd & nd \\
\hline $\begin{array}{c}\text { Amina } \\
2\end{array}$ & nd & $\begin{array}{c}+0,03 \\
(S)\end{array}$ & $\mathrm{CHCl}_{3}$ & & $\begin{array}{c}+7,2 \\
(S)\end{array}$ & $\mathrm{CHCl}_{3}$ & 0,49 & $\begin{array}{l}\text { MASUTANI } \\
\text { et al., } 2006 .\end{array}$ \\
\hline $\begin{array}{c}\text { Amida } \\
6\end{array}$ & 78 & $\begin{array}{c}+0,248 \\
(R)\end{array}$ & $\mathrm{EtOH}$ & 1 & $\begin{array}{c}-35,2 \\
(S)\end{array}$ & $\mathrm{EtOH}$ & 1,2 & $\begin{array}{l}\text { ENDERS, } \\
\text { HARNYING, } \\
2004 .\end{array}$ \\
\hline $\begin{array}{c}\text { Amina } \\
3\end{array}$ & nd & $\begin{array}{c}+0,082 \\
(S)\end{array}$ & $\mathrm{MeOH}$ & 1 & $\begin{array}{c}+27,9 \\
(S)\end{array}$ & $\mathrm{MeOH}$ & 0,51 & $\begin{array}{l}\text { NECHAB et } \\
\text { al., } 2007 .\end{array}$ \\
\hline $\begin{array}{c}\text { Amida } \\
7\end{array}$ & 75 & $\begin{array}{c}+1,010 \\
(R)\end{array}$ & $\mathrm{CHCl}_{3}$ & 1 & $\begin{array}{c}+83,6 \\
(R)\end{array}$ & $\mathrm{CHCl}_{3}$ & 1 & $\begin{array}{l}\text { KIM et al., } \\
2007 .\end{array}$ \\
\hline $\begin{array}{c}\text { Amida } \\
8\end{array}$ & 67 & nd & nd & nd & nd & nd & nd & nd \\
\hline
\end{tabular}

nd $=$ não determinado.

Os resultados obtidos neste trabalho foram semelhantes aos descritos na literatura quando comparadas a conversão e o excesso enantiomérico, porém conseguiu-se uma redução no tempo reacional que foi de 10 horas frente aos resultados de Garcia-Urdiales et al. (2000). Para a amina 1 em hexano na presença de CAL-B e acetato de etila como acilante obteve-se uma conversão de $42 \%$ e um excesso enantiomérico de $88 \%$ (tempo $=7 \mathrm{~h}$ ), resultado similar ao de Garcia-Urdiales et al. (2000) que para a mesma amina $\mathbf{1}$ obteve um conversão de $49 \%$ e um ee de $97 \%$ em dioxano na presença de CAL-B e tendo como acilante o acetato de 1 -fenil etila (tempo $=17 \mathrm{~h})$.

Para a amina 2 foi possivel observar que a quantidade de lipase presente no meio influenciou positivamente no tempo reacional. Neste trabalho foram utilizados $2 \mathrm{mg}$ de CAL-B em hexano e com acetato de etila como acilante, obtendo uma conversão de $22 \%$ e um ee > 99\% em 60 horas. Gonzalez-Sabin et al. (2002) obtiveram uma conversão de 51\% com um ee de $86 \%$ quando utilizados $300 \mathrm{mg}$ de CAL-B em acetato de etila como solvente e agente acilante em um tempo reacional de 4 horas.

Os resultados referentes à naftilamina 3 mostraram que o melhor ee obtido (19\%) foi utilizando a lipase HPL, como agente acilante o acetato de vinila em hexano a $70{ }^{\circ} \mathrm{C}$ sob aquecimento por irradiação MO. Para a lipase de CAL$\mathrm{B}$, agente acilante acetato de etila em hexano por $7 \mathrm{~h}$ foi obtida $\mathrm{c}=1 \%$ e ee= 9\%. Os resultados obtidos por Skupinska et al. (2003) onde foram utilizados a CAL-B e o acetato de etila como acilante em éter isopropílico foram obtidas 
conversão de $64 \%$ e ee de $48 \%$ para a amida 7 . Sabe-se que o solvente influência muito na conformação do sítio ativo da enzima alterando o resultado das reações, os resultados obtidos no presente trabalho diferem dos obtidos por Skupinska et al. (2003) pois foram realizados em hexano como solvente.

Com relação à amina 4 não existem trabalhos relatados na literatura, entretanto devido a mistura de diastereoisomeros, não foi possível obter a separação dos enantiômeros para a determinação dos excessos enantioméricos. 


\subsection{Conclusões}

Os estudos realizados na resolução cinética enzimática de aminas primárias 1-4 é possível concluir que a melhor condição reacional se deu quando o solvente utilizado foi o hexano, como agente acilante o acetato de etila a uma temperatura de $30^{\circ} \mathrm{C}$ e adicionando $2 \mathrm{mg}$ de enzima como catalisador. Para a determinação das condições reacionais foi utilizada a 2-amino heptano (1) e foi obtida conversão de $42 \%$ e excesso enantiomérico da amida (5) de $88 \%$. O hexano é um solvente hidrofóbico o que ajuda a manter a conformação da enzima e melhorar sua atividade catalítica.

No estudo da influência da temperatura a resolução a $60^{\circ} \mathrm{C}$ foi possível observar decréscimo no excesso enantiomerico. Isso ocorreu provavelmente porque com o aumento da temperatura há maior mobilidade molecular elevando o número de colisões efetivas entre o sítio ativo e ambos os enantiômeros diminuindo a enantiosseletividade da enzima e consequentemente a pureza enantiomérica do produto.

Quando avaliada a influência da quantidade de catalisador presente no meio reacional, constatou-se que com o aumento da massa de enzima o único parâmetro alterado foi o tempo reacional, ocorrendo uma diminuição do mesmo e mantendo o excesso enantiomérico. Para avaliação da influência da quantidade de lipase foi utilizada a 1,2,3,4-tetra-hidro-1-naftilamina (3) e as lipases que apresentaram redução no tempo reacional foram: A. niger de 7 dias $(c=2 \%)$ para 2 dias $(\mathrm{c}=2 \%)$, C. cylindracea e CAL-B de 7 dias $(\mathrm{c}=7 \%)$ para 1 dia $(\mathrm{c}=5 \%)$ e Lipase de pâncreas suíno (PPL) de 7 dias para 1 dia e aumento na conversão de $4 \%$ para $68 \%$.

A mesma resolução cinética enzimática de aminas primárias quando realizada sob o efeito de irradiações micro-ondas apresentou boas conversões, porém ee's baixos.

Os melhores valores de excessos enantiomericos foram obtidos com a utilização da CAL-B inclusive sob ação de radiação micro-ondas, um dos fatores que favorece tais resultados é o fato da enzima se encontrar na forma imobilizada o que confere maior estabilidade estrutural e térmica. Para as aminas $\mathbf{1}$ e 2 em hexano a $70{ }^{\circ} \mathrm{C}$ sob irradiação micro-ondas e agente acilante o acetato de etila foram obtidos os excessos enantioméricos de 99\% para a amida 5 e $40 \%$ para a amida 6 . As amidas 7 e 8 os excessos enantioméricos não foram determinados nestas condições devido a não conversão da amina em amida. 

CAPÍTULO

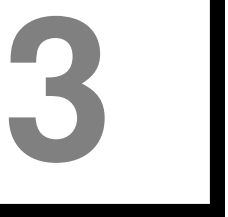

\section{Reações de adição de Michael catalisada por lipases}

\section{1 Materiais e Métodos}

\subsubsection{Enzimas}

1. A Lipase imobilizada em resina acrílica de Candida antarctica (CAL-B) $\geq$ 10,000 U/g, recombinante, expressa em Aspergillus oryzae foi doada por Novo Nordisk (Brasil).

2. Lipase de pâncreas suíno (PPL), 30-90 U/mg proteína. Uma unidade é capaz de hidrolisar 1,0 $\mu$ eq. de triacetina em 1 h com $\mathrm{pH} 7,7$ a $37^{\circ} \mathrm{C}$.

3. Lipase de Candida rugosa (CRL) tipo VII $\geq 700 \mathrm{U} / \mathrm{mg}$. Uma unidade é capaz de hidrolisar 1,0 $\mu$ eq. de ácido graxo a partir de um triglicerídeo em 1 hora com $\mathrm{pH} 7,2$ a $37^{\circ} \mathrm{C}$.

4. Lipase de Candida cilindracea (CCL) 4,9 U/mg. Uma unidade corresponde à quantidade de enzima a qual libera $1 \mu \mathrm{mol}$ de ácido oléico por minuto com $\mathrm{pH} 8,0$ e $40^{\circ} \mathrm{C}$.

5. Lipase de hog pancreas (HPL) 30,1 U/mg. Uma unidade corresponde à quantidade de enzima a qual libera $1 \mu$ mol de ácido graxo a partir de triglicerídeos por minuto com $\mathrm{pH} 8,0$ e $37^{\circ} \mathrm{C}$ de óleo de oliva como substrato. 
As enzimas foram compradas das empresas Amano Europe, Fluka - Sigma (Steinheim, Germany) e da Sigma (Steinheim, Germany), exceto a CAL-B que foi doada pela NovoNordisk

\subsubsection{Equipamentos}

Os espectros de $\mathrm{RMN}{ }^{1} \mathrm{H}$ e ${ }^{13} \mathrm{C}$ foram obtidos em um espectrômetro Bruker AC-200 $\left({ }^{1} \mathrm{H}\right.$ a $200 \mathrm{MHz}$ e ${ }^{13} \mathrm{C}$ a $\left.50 \mathrm{MHz}\right)$. Os espectros foram feitos em clorofórmio-d $\left(\mathrm{CDCl}_{3}\right)$ e os deslocamentos químicos ( $\delta$ ) são dados em ppm usando tetrametilsilano (TMS) como padrão interno de referência. Os espectros de massa de alta resoluçao foram obtidos usando ionização elétron spray (IES) ( Ion trap linear híbrido- orbitrap FT-MS e QqTOF/MS-Microtof- modelo QII).

Adições de Michael enzimáticas foram realizadas utilizando-se um agitador orbital Tecnal TE-421 e um reator de irradiação micro-ondas CEM Discover 1.

As reações enzimáticas foram analisadas utilizando um cromatógrafo Shimadzu GC 2010 equipado com um auto injetor AOC 20i, com um detector de ionização em chama (FID), e uma coluna J\&W Column DB-5 (30m x 0,25mm x $0,1 \mu),(5 \%$-fenil)-metilpolisiloxano) para a determinação das conversões.

\subsubsection{Reagentes}

As aminas primárias foram adquiridas da empresa Aldrich, sendo que a ciclo-hexilamina foi adquirida da Fluka na proporção de 8:2 cis:trans.

Os reagentes e solventes utilizados foram obtidos comercialmente ou quando necessário purificados e/ou secos utilizando procedimentos descritos na literatura (Armarego \& Chai, 2009). As separações em colunas cromatográficas dos produtos foram realizados utilizando-se sílica gel 60 (400-230 mesh) e mistura de hexano/acetato de etila como eluentes.

\section{1.4 Procedimentos experimentais em escala analítica}

Experimento I - Adição de Michael catalisada por lipases sob agitação orbital

A adição de Michael catalisada por lipases é apresentada na Figura 3.1

Em um frasco Erlenmeyer de $50 \mathrm{~mL}$ foram adicionados $5 \mathrm{~mL}$ do solvente (hexano ou água), acrilonitrila $(0,1 \mathrm{~mL}-1,5 \mathrm{mmol})$, aminas 1-4 (0,6 mmol) e as lipases (10450 unidades catalíticas). A mistura reacional permaneceu sob agitação orbital a $130 \mathrm{rpm}$ e $30^{\circ} \mathrm{C}$ por 3 minutos. As reações após finalizadas foram filtradas e extraídas com acetato de etila. As amostras foram concen- 
Figura 3.1: Reação de adição de Michael catalisada por lipases em agitação orbital

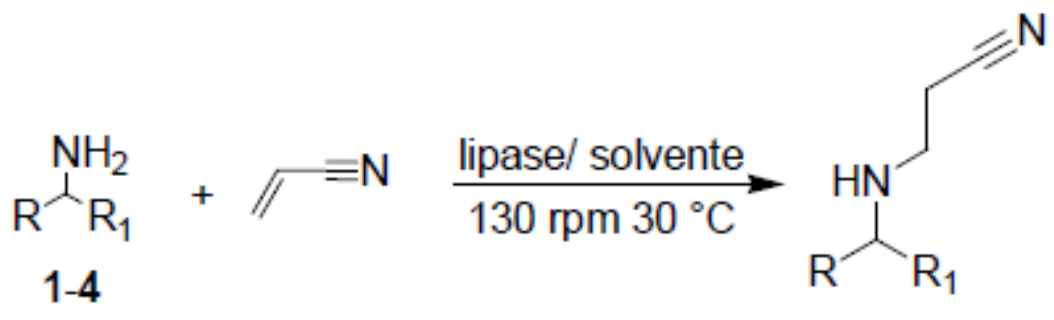

9-12

tradas em rotaevaporador e posteriormente diluídas em vials até o volume de $1,5 \mathrm{~mL}$ e analisadas por cromatografia a gás.

Experimento II - Adição de Michael catalisada por lipase em reator de microondas.

A adição de Michael catalisada por lipases é apresentada na Figura 3.2

Figura 3.2: Reação de adição de Michael catalisada por lipases sob irradiação MO

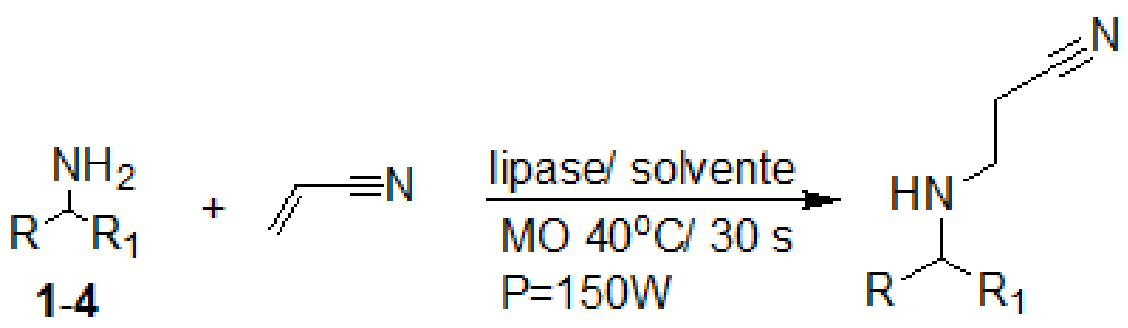

\section{9-12}

Em um balão de fundo redondo de $5 \mathrm{~mL}$ foram adicionados $1 \mathrm{~mL}$ do solvente (hexano ou água), acrilonitrila $(0,1 \mathrm{~mL}-1,5 \mathrm{mmol})$, aminas 1-4 $(0,6$ mmol) e as lipases (10450 unidades catalíticas). A mistura reacional permaneceu sob irradiação micro-ondas por $30 \mathrm{~s}$ a $40^{\circ} \mathrm{C}$ com potência máxima de $150 \mathrm{~W}$. As reações foram filtradas e extraídas com acetato de etila. As amostras foram concentradas em rotaevaporador e posteriormente diluídas em vials até o volume de 1,5 mL e analisadas por cromatografia a gás.

\section{1.5 Procedimentos experimentais em escala quantitativa}

Experimento I - Adição de Michael catalisada por lipases sob agitação orbital

Em um frasco Erlenmeyer de $50 \mathrm{~mL}$ foram adicionados $5 \mathrm{~mL}$ do solvente (hexano ou água), acrilonitrila $(0,1 \mathrm{~mL}-1,5 \mathrm{mmol})$, aminas 1-4 $(1 \mathrm{mmol}) \mathrm{e}$ 
CAL-B (10 mg). A mistura reacional permaneceu sob agitação orbital a 130 rpm e $30^{\circ} \mathrm{C}$ por 3 minutos. As reações foram filtradas e extraídas com acetato de etila. As amostras foram concentradas em rotaevaporador e posteriormente diluídas em vials até o volume de 1,5 mL e analisadas por cromatografia a gás. Os produtos foram purificados em coluna cromatográfica de sílica gel com eluente consistindo de hexano/acetato de etila.

Experimento II - Adição de Michael catalisada por lipase em reator de microondas.

Em um balão de fundo redondo de $5 \mathrm{~mL}$ foram adicionados $3 \mathrm{~mL}$ do solvente (hexano ou água), acrilonitrila $(0,1 \mathrm{~mL}-1,5 \mathrm{mmol})$, aminas $\mathbf{1 - 4}$ ( $1 \mathrm{mmol}$ ) e CAL-B (10 mg). A mistura reacional permaneceu sob irradiação micro-ondas por $30 \mathrm{~s}$ a $40^{\circ} \mathrm{C}$ com potência máxima de $150 \mathrm{~W}$. Após a reação ser interrompida foi filtrada. Os produtos extraídos foram purificados em coluna cromatográfica de sílica gel com eluente consistindo de hexano/acetato de etila e analisados por cromatografia a gás.

\section{1.6 Dados espectroscópicos e cromatográficos}

\section{3-(( 1-metil-hexil)amino)propanonitrila (9)}

Dados experimentais: $\mathrm{RMN}{ }^{1} \mathrm{H}\left(200 \mathrm{MHz}, \mathrm{CDCl}_{3}\right), \delta(\mathrm{ppm}): 12,88(\mathrm{~m}, 1 \mathrm{H})$; $2,62(\mathrm{~m}, 2 \mathrm{H}) ; 2,45(\mathrm{t}, 2 \mathrm{H}, J=6,54) ; 1,40(\mathrm{~m}, 2 \mathrm{H}) ; 1,25(\mathrm{~m}, 6 \mathrm{H}) ; 0,85(\mathrm{t}, 1 \mathrm{H}$, $J=6,93) ; \mathrm{RMN}{ }^{13} \mathrm{C}\left(50 \mathrm{MHz}, \mathrm{CDCl}_{3}\right), \delta$ (ppm): 118,7; 52,4; 42,3; 36,9; 32,5; 31,$9 ; 22,5 ; 20,2 ; 19,0 ; 13,9$.Os dados espectroscópicos estão de acordo com os relatados na literatura (Dyck et al., 2006). O eluente para coluna cromatográfica foi hexano/acetato de etila $(7 / 3 ; \mathrm{v} / \mathrm{v})$. As condições aplicadas na cromatografia a gás foram as seguintes: gás de arraste: nitrogênio (60 kPa); temperatura do injetor: $250^{\circ} \mathrm{C}$; razão de split do injetor: 1:20; temperatura do detector: $250^{\circ} \mathrm{C}$; forno (temperatura inicial): $120^{\circ} \mathrm{C}$; forno (temperatura final): $160^{\circ} \mathrm{C}$ por $11 \mathrm{~min}$; taxa de aquecimento: $5^{\circ} \mathrm{C} / \mathrm{min}$, e tempo de análise: 19 min. Tempo de retenção do composto $\mathbf{2}=10,8 \mathrm{~min}$ (Figura 3.3. Rendimento isolado para MO e CAL-B $=77 \%$. HRMS $m / z$ calculado para $\mathrm{C}_{10} \mathrm{H}_{20} \mathrm{~N}_{2}(\mathrm{M}+\mathrm{H})^{+}$ 169, 1660 encontrado 169,171 19 (Figura 3.4). FTIR (cm-1) 3315,68; 2956,78; 2920,81; 2856,40; 2246,50; 1465,16; 1379,00; 726,46; 611 ,01 (Figura 3.5). 
Figura 3.3: Cromatograma da 3-[(1-metil-hexil)amino]propanonitrila (9) por cromatografia a gás em coluna DB-5

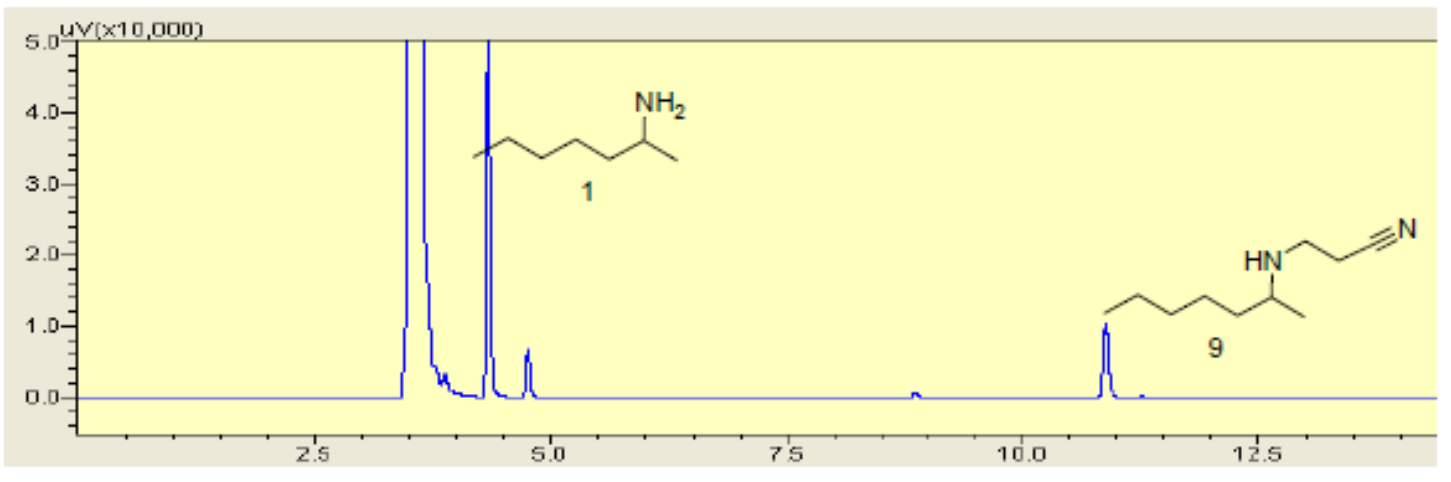

Figura 3.4: Espectro de massas TOF da 3-[(1-metilhexil)amino]propanonitrila (9)

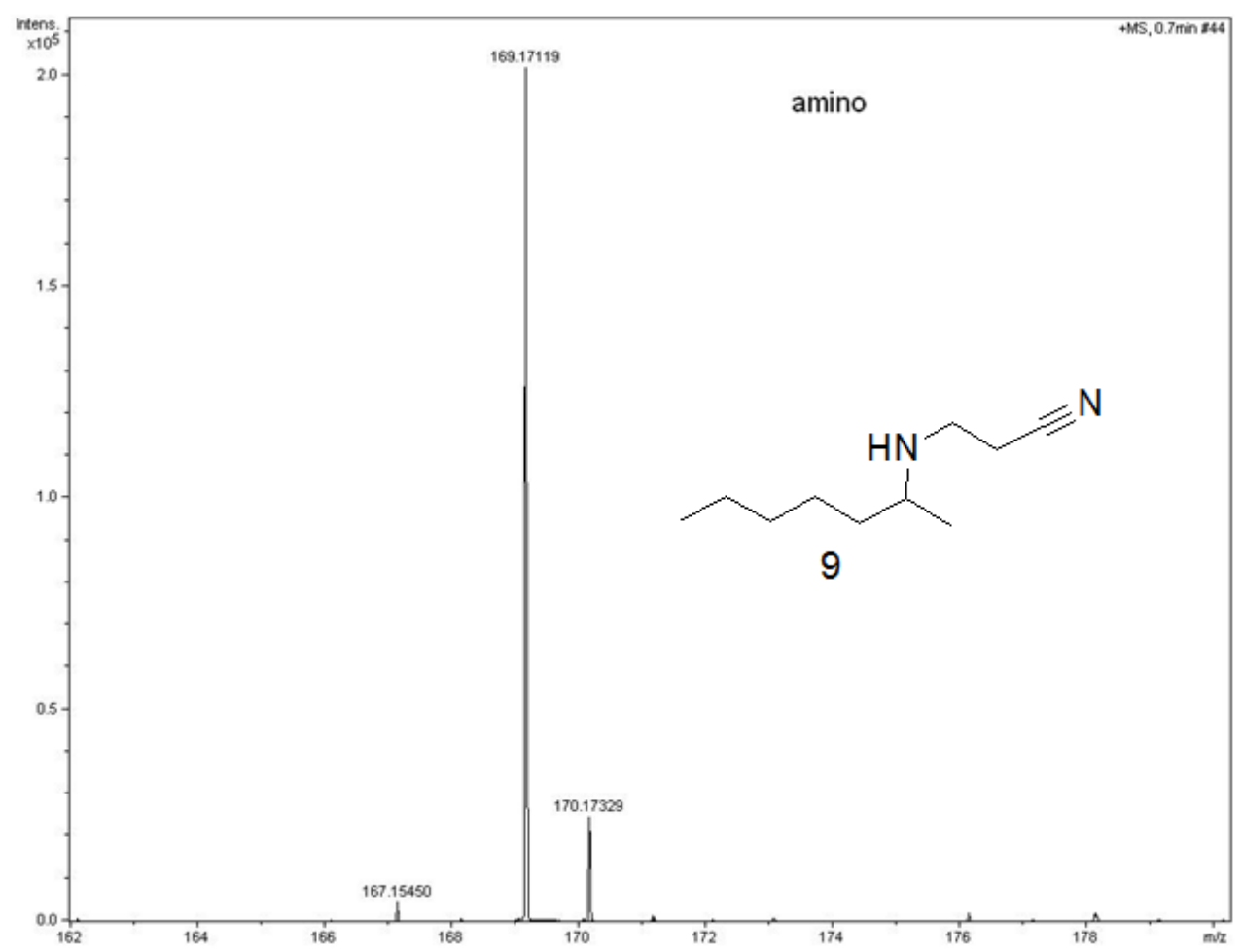


Figura 3.5: Espectro de Infra-vermelho da 3-[(1-metilhexil)amino]propanonitrila (9)

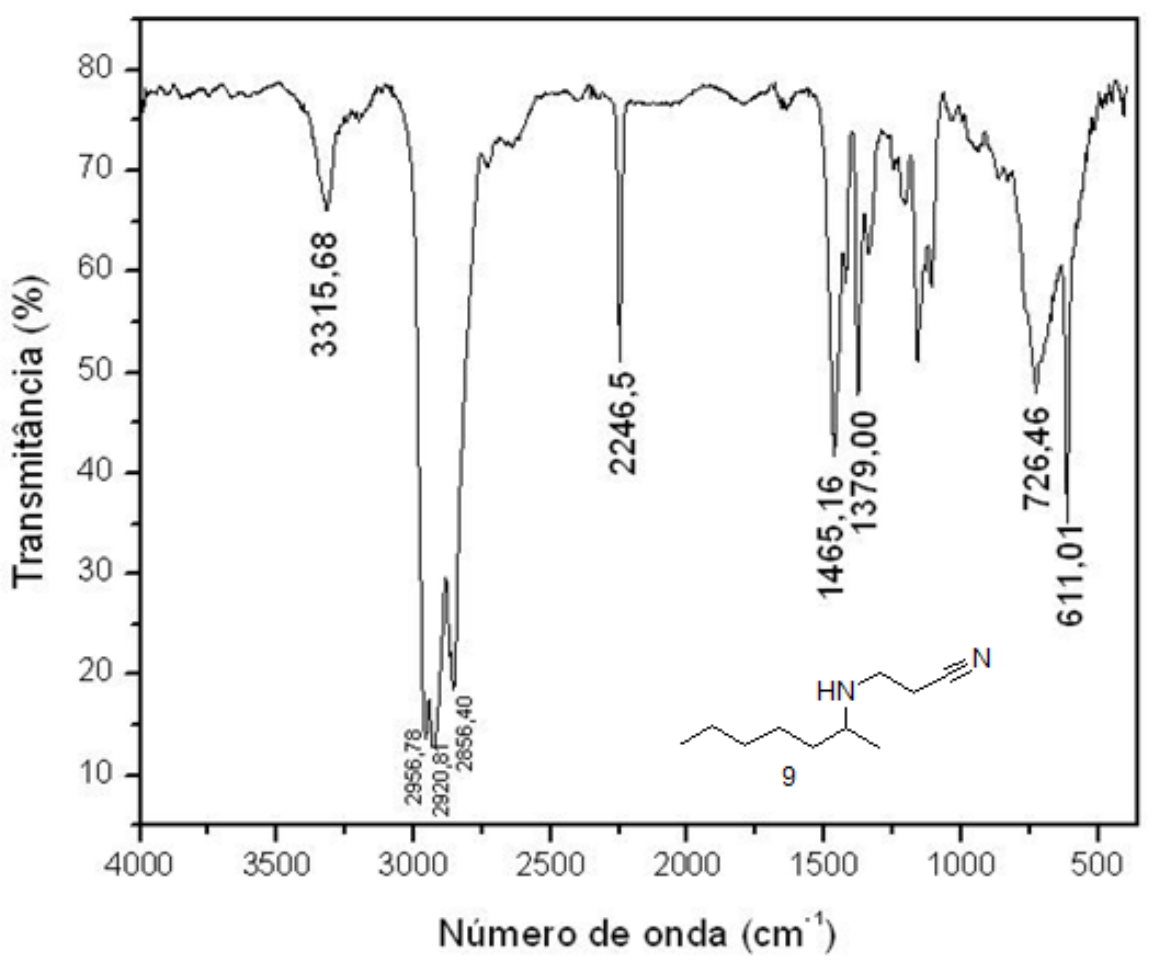


3-((1-metil-3-fenil-propil)amino)propanonitrila (10)

Dados experimentais: RMN ${ }^{1} \mathrm{H}\left(200 \mathrm{MHz}, \mathrm{CDCl}_{3}\right), \delta(\mathrm{ppm}): 7,21(\mathrm{~m}, 2 \mathrm{H})$; 7,12 (m, 3H); 2,87 (m, 1H); 2,78 (m, 1H); 2,62 (m, 2H); 2,38 (t, $2 \mathrm{H}, J=6,73)$; $1,69(\mathrm{~m}, 1 \mathrm{H}) ; 1,58(\mathrm{~m}, 1 \mathrm{H}) ; 1,37(\mathrm{~s}, \mathrm{NH}) ; 1,05(\mathrm{~d}, 3 \mathrm{H}, \mathrm{J}=6,44) ; \mathrm{RMN}{ }^{13} \mathrm{C}$ (50 MHz, $\mathrm{CDCl}_{3}$ ), $\delta$ (ppm): 141,9; 128,2; 128,1; 125,6; 118,7; 51,8; 42,1; 38,$4 ; 32,0 ; 20,2 ; 18,9$. Eluente para coluna cromatográfica foi hexano/acetato de etila $(1 / 1 ; \mathrm{v} / \mathrm{v})$. As condições utilizadas na cromatografia a gás foram as seguintes: gás de arraste: nitrogênio $(60 \mathrm{kPa})$; temperatura do injetor: $250^{\circ} \mathrm{C}$; razão de split do injetor: 1:20; temperatura do detector: $250^{\circ} \mathrm{C}$; forno: $190^{\circ} \mathrm{C}$ por $22 \mathrm{~min}$; e tempo de análise: $19 \mathrm{~min}$. Tempo de retenção do composto $6=13,4 \mathrm{~min}$ (Figura 3.6). Rendimento isolado para MO e CAL-B $=67 \%$. HRMS $m / z$ calculado para $\mathrm{C}_{13} \mathrm{H}_{18} \mathrm{~N}_{2}(\mathrm{M}+\mathrm{H})^{+} 203,1504$ encontrado 203,15495 (Figura 3.7). IV (cm $\left.{ }^{-1}\right)$ 3028; 2942; 2856; 2246; 1608; 1493; 1450; 1378; 1142; 747; 704; 604 (Figura 3.8).

Figura 3.6: Cromatograma da 3-[(1-metil-3-fenilpropil)amino] propanonitrila (10) por cromatografia a gás em coluna DB-5

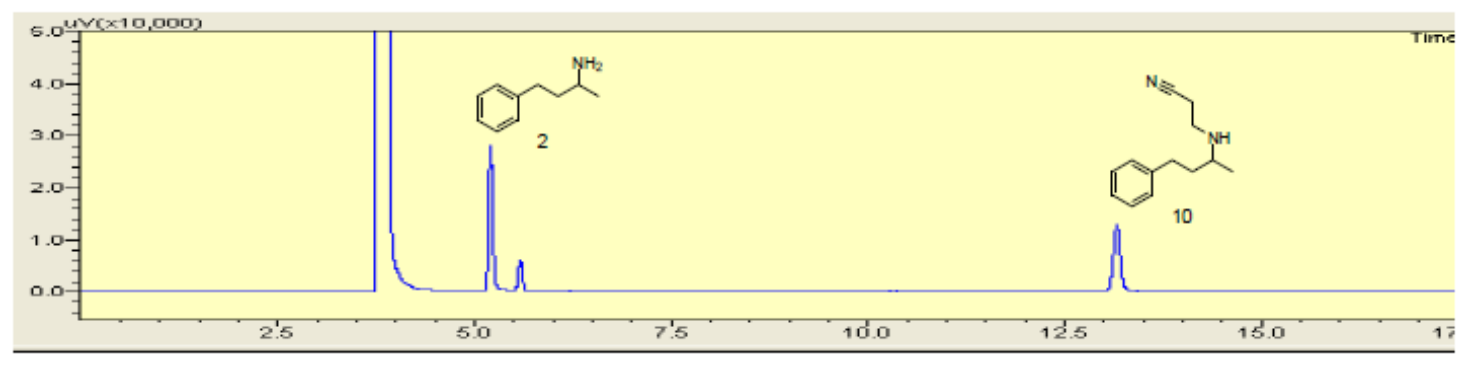


Figura 3.7: Espectro de massas TOF da 3-[(1-metil-3-fenilpropil)amino] propanonitrila (10)

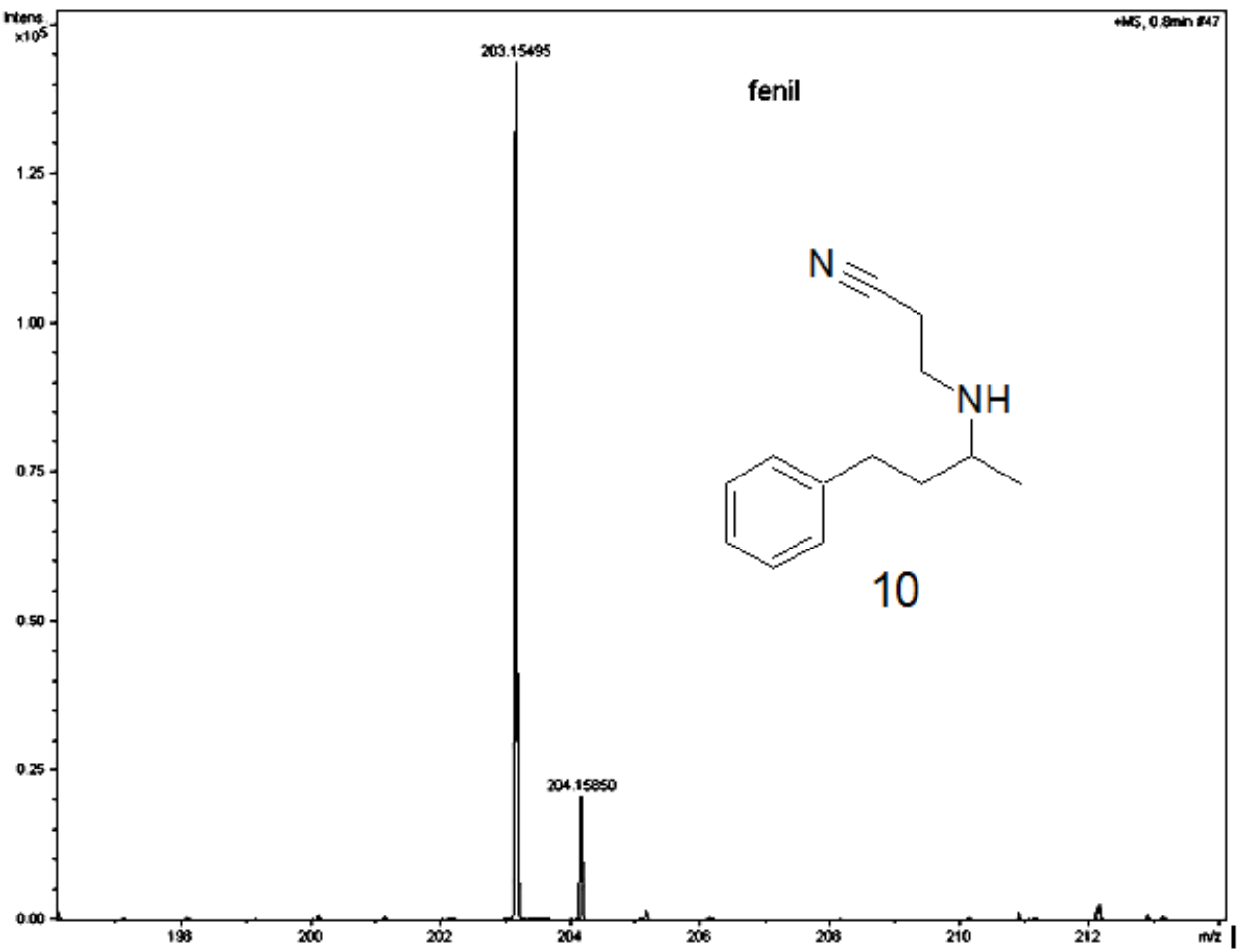

Figura 3.8: Espectro de Infra-vermelho da 3-[(1-metil-3-fenilpropil)amino] propanonitrila (10)

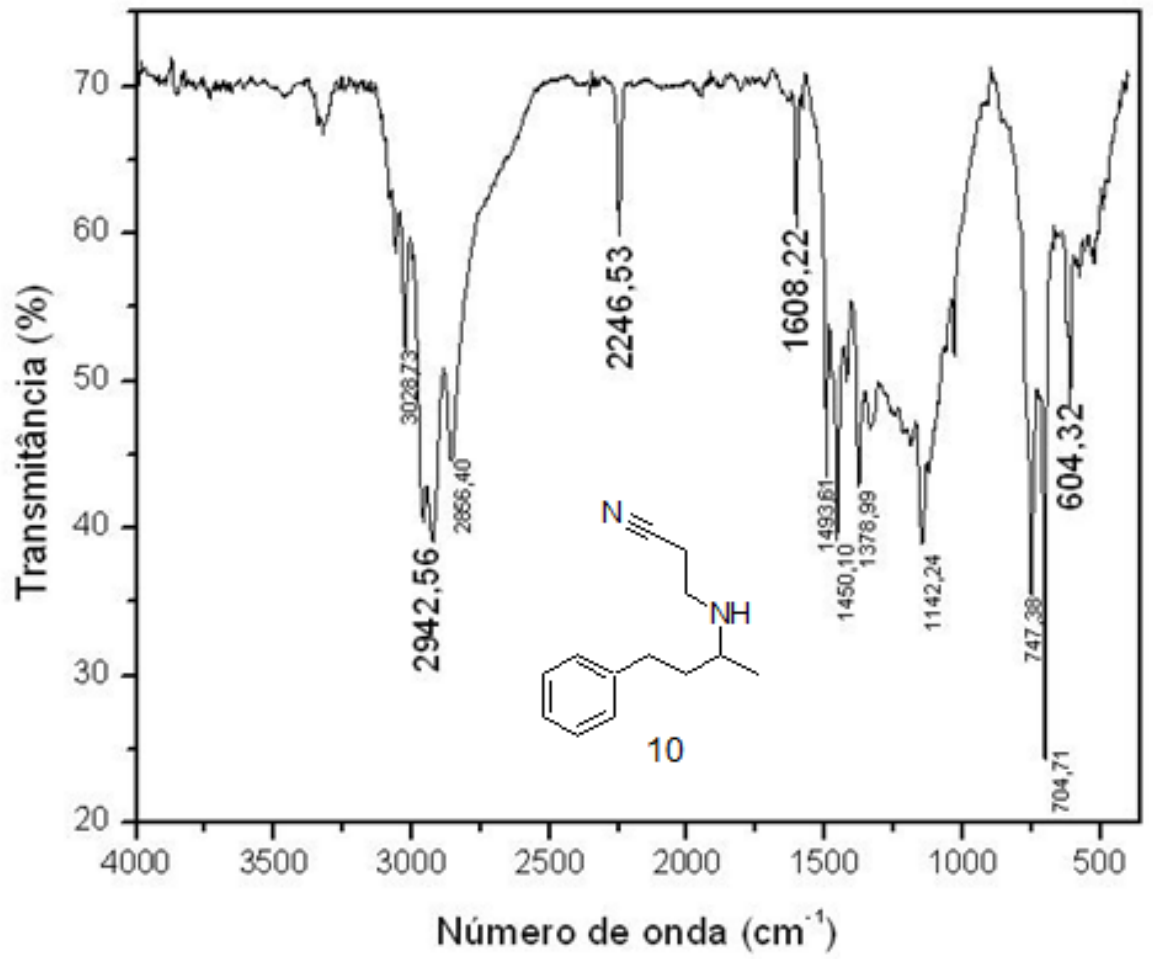


3-(1,2,3,4-tetra-hidronaftaleno-7-amino)propanonitrila (12)

Dados experimentais: RMN ${ }^{1} \mathrm{H}\left(200 \mathrm{MHz}, \mathrm{CDCl}_{3}\right), \delta(\mathrm{ppm})$ : 7,38 (m, $\left.1 \mathrm{H}\right)$; $7,15(\mathrm{~m}, 2 \mathrm{H}) ; 7,07(\mathrm{~m}, 1 \mathrm{H}) ; 3,81(\mathrm{t}, 1 \mathrm{H}, J=4,8) ; 3,00(\mathrm{~m}, 2 \mathrm{H}) ; 2,81(\mathrm{~m}, 1 \mathrm{H})$; $2,72(\mathrm{~m}, 1 \mathrm{H}) ; 2,52(\mathrm{~m}, 2 \mathrm{H}) ; 1,93(\mathrm{~m}, 2 \mathrm{H}) ; 1,77(\mathrm{~m}, 2 \mathrm{H}) \mathrm{RMN}{ }^{13} \mathrm{C}(50 \mathrm{MHz}$, $\left.\mathrm{CDCl}_{3}\right), \delta$ (ppm): 138,2; 137,3; 129,0; 128,6;126,8; 125,7; 118,8; 55,0; 42,3; 29,$1 ; 28,4 ; 20,0 ; 19,0$. Eluente para coluna cromatográfica foi hexano/acetato de etila $(7 / 3 ; \mathrm{v} / \mathrm{v})$. As condições utilizadas na cromatografia a gás foram as seguintes: gás de arraste: nitrogênio $(60 \mathrm{kPa})$; temperatura do injetor: $250^{\circ} \mathrm{C}$; razão de split do injetor: 1:20; temperatura do detector: $250^{\circ} \mathrm{C}$; forno: $190^{\circ} \mathrm{C}$ por 22 min.; tempo de análise: 19 min. Tempo de retenção do composto 11 $=13,4$ min (Figura 3.9). Rendimento isolado para MO e CAL-B $=85 \%$. HRMS $m / z$ calculado para $\mathrm{C}_{13} \mathrm{H}_{18} \mathrm{~N}_{2}(\mathrm{M}+\mathrm{H})^{+} 201,13$ (o composto degrada no injetor, por isso não foi possível obter o espectro de massas TOF). IV $\left(\mathrm{cm}^{-1}\right) 3329$; $3021 ; 2935 ; 2856 ; 2246 ; 1486 ; 1443 ; 1112 ; 740$ (Figura 3.10).

Figura 3.9: Cromatograma da 3-(1,2,3,4-tetra-hidronaftaleno-1-amino) propanonitrila (12) por cromatografia a gás em coluna DB-5

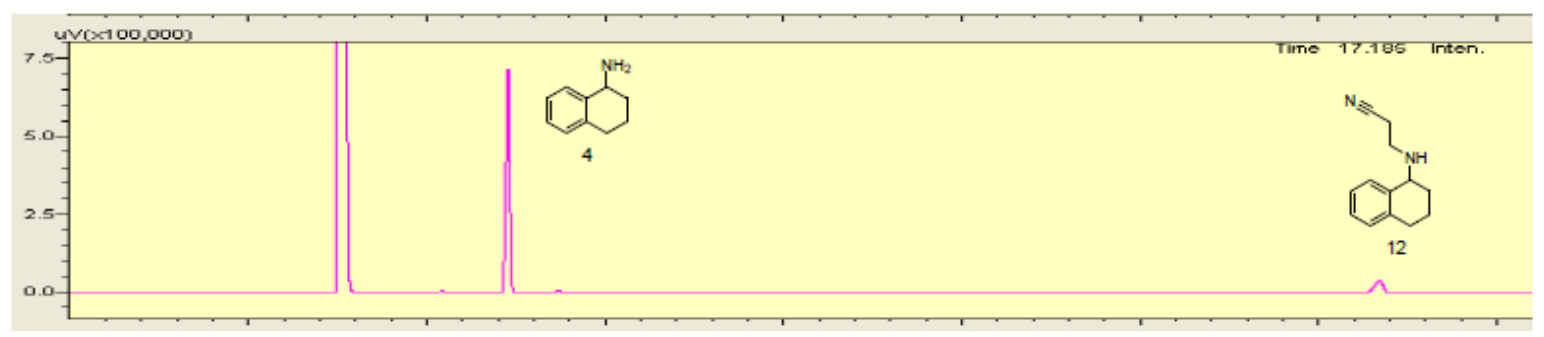


Figura 3.10: Espectro de Infra-vermelho da 3-(1,2,3,4-tetrahidronaftaleno-1-amino) propanonitrila (12)

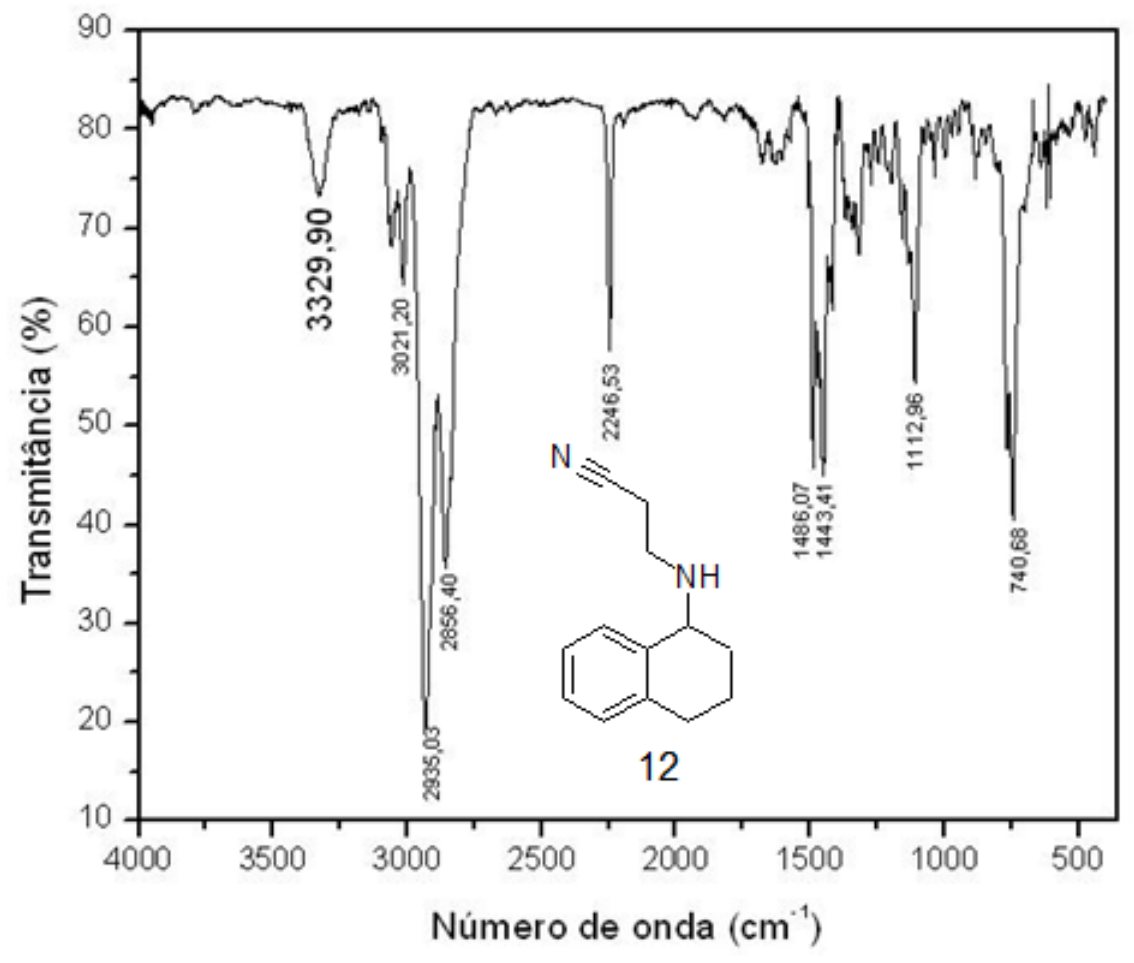

3-((2-metil cicloexil)amino)propanonitrila (11)

Dados experimentais: $\mathrm{RMN}^{1} \mathrm{H}\left(200 \mathrm{MHz}, \mathrm{CDCl}_{3}\right), \delta(\mathrm{ppm}): 2,96(\mathrm{~m}, 1 \mathrm{H})$; $2,81(\mathrm{~m}, 1 \mathrm{H}) ; 2,56(\mathrm{~m}, 1 \mathrm{H}) 2,43(\mathrm{~m}, 2 \mathrm{H}) ; 1,98(\mathrm{~m}, 1 \mathrm{H}) ; 1,81(\mathrm{~m}, 1 \mathrm{H}) ; 1,62$ $(\mathrm{m}, 1 \mathrm{H}) ; 1,39(\mathrm{~m}, 1 \mathrm{H}) ; 1,19(\mathrm{~m}, 4 \mathrm{H}) ; 0,93(\mathrm{~d}, 3 \mathrm{H}, \mathrm{J}=6,44)$; RMN ${ }^{13} \mathrm{C}(50 \mathrm{MHz}$, $\mathrm{CDCl}_{3}$ ), $\delta$ (ppm): 118,7; 62,0;41,9;37,7;34,3;32,2;25,6;25,2;19,0;13,8. Eluente para coluna cromatográfica foi hexano/acetato de etila $(7 / 3 \mathrm{v} / \mathrm{v})$. As condições utilizadas na cromatografia a gás foram as seguintes: gás de arraste: nitrogênio $(60 \mathrm{kPa})$; temperatura do injetor: $250^{\circ} \mathrm{C}$; razão de split do injetor: 1:20; temperatura do detector: $250^{\circ} \mathrm{C}$; forno: $190^{\circ} \mathrm{C}$ por $22 \mathrm{~min}$; tempo de análise: $19 \mathrm{~min}$. Tempo de retenção do composto 4: cis = 9,8 min. e trans $=10,3$ min (Figura 3.11). Rendimento isolado para MO e CAL-B $=44 \%$. MS $m / z$ calculado para $\mathrm{C}_{10} \mathrm{H}_{18} \mathrm{~N}_{2}(\mathrm{M}+\mathrm{H})^{+} 167,1504$ encontrado 167,15540 (Figura 3.12). IV (cm-1) 2928; 2856; 2246; 1461; 1128; $711 ; 611$ (Figura 3.13). 
Figura 3.11: Cromatograma da 3-[(2-metil-cicloexil)amino] propanonitrila (11) por cromatografia a gás em coluna DB-5

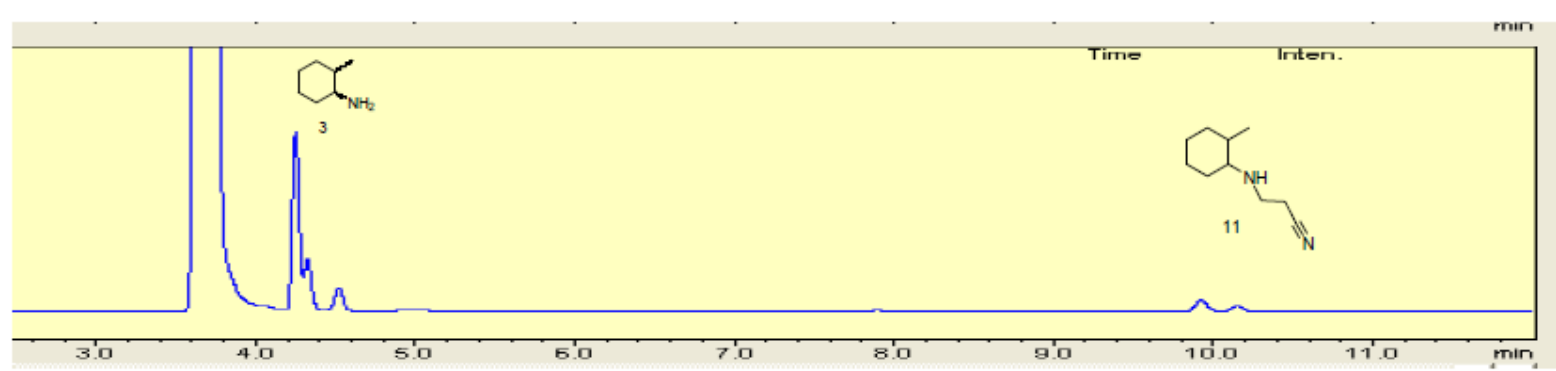

Figura 3.12: Espectro de massas TOF da 3-[(2-metil cicloexil)amino] propanonitrila (1 1)

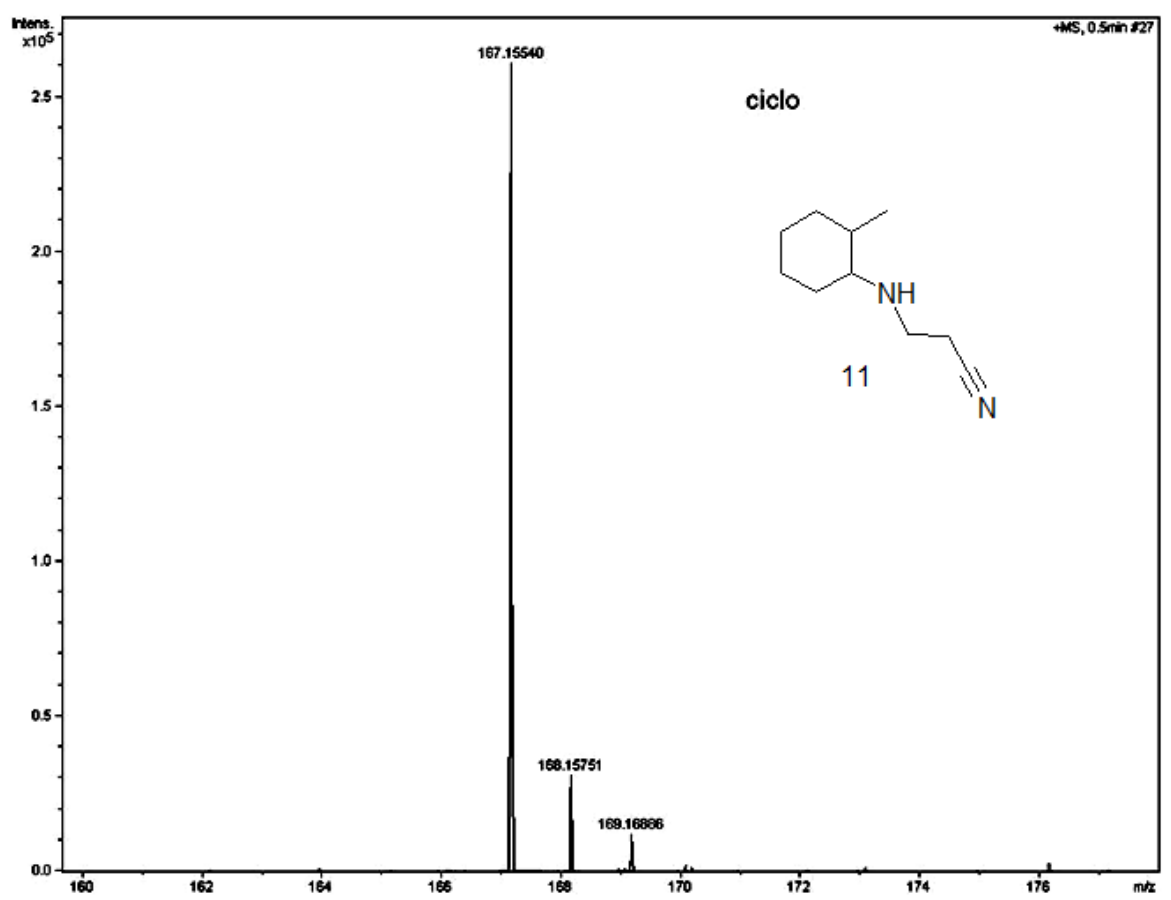


Figura 3.13: Espectro de infra-vermelho da 3-[(2-metil cicloexil)amino] propanonitrila (11)

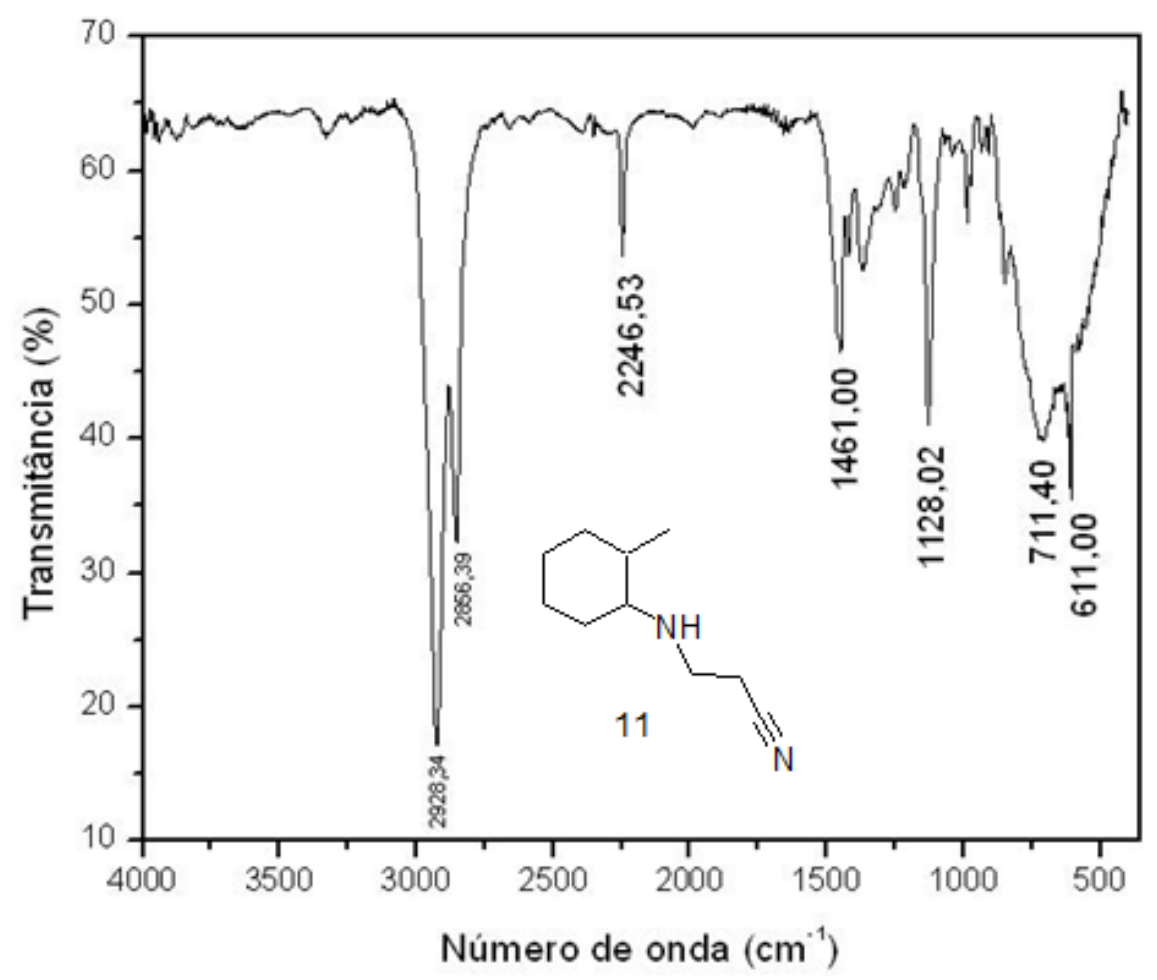




\subsection{Resultados e Discussão}

As lipases utilizadas nas reações de adição de Michael foram a CAL-B, Candida rugosa (CRL), Candida cilindracea (CCL), HPL e PPL. As aminas primárias estudadas como doadores de Michael foram a 2-amino-heptano $\mathbf{1}$, 2-metil-cicloexil amina 3, 1-metil-3-fenilpropilamina 2, 1,2,3,4-tetra-hidro-1naftilamina 4, e como aceptor de Michael foi utilizada a acrilonitrila. Todas as reações foram inicialmente realizadas sob agitação orbital.

A reação de adição de Michael foi inicialmente estudada em hexano como solvente e como nucleófilos as aminas 2-amino-heptano (1), 2-metil-cicloexil amina (2), 1-metil-3-fenilpropilamina (3), 1,2,3,4-tetra-hidro-1-naftilamina (4). As reações de adição de Michael foram comparadas frente aos resultados obtidos para a reação na ausência de enzima (branco) com 4 e 7 dias de reação e na presença da lipase de CAL-B com 2 dias. Foi possível observar que a lipase forneceu uma melhor conversão com apenas metade do tempo em relação à reação sem enzima, sugerindo uma possível ação catalítica da enzima na reação de adição de Michael.

Nestes estudos o melhor resultado foi obtido com a amina $\mathbf{2}$ que forneceu o aduto de Michael 10 com 43\% de conversão (Tabela 3.1). Em razão dos baixos rendimentos dos produtos obtidos em hexano, realizaram-se as reações em água, por ser um solvente mais polar e se demonstrar mais apropriado à radiação de MO. Neste estudo utilizou-se como substrato a 2-amino-heptano (1), juntamente com a acrilonitrila. As reações também foram realizadas na ausência de MO para verificar as diferenças entre os experimentos. Ainda nestes estudos também foi realizada uma triagem com 4 outras lipases comerciais (CCL, CRL, HPL e PPL). Os resultados obtidos destes experimentos estão demonstrados na Tabela 3.2. 
Tabela 3.1: Reação de adição de Michael entre aminas 1-4 e acrilonitrila em agitador orbital

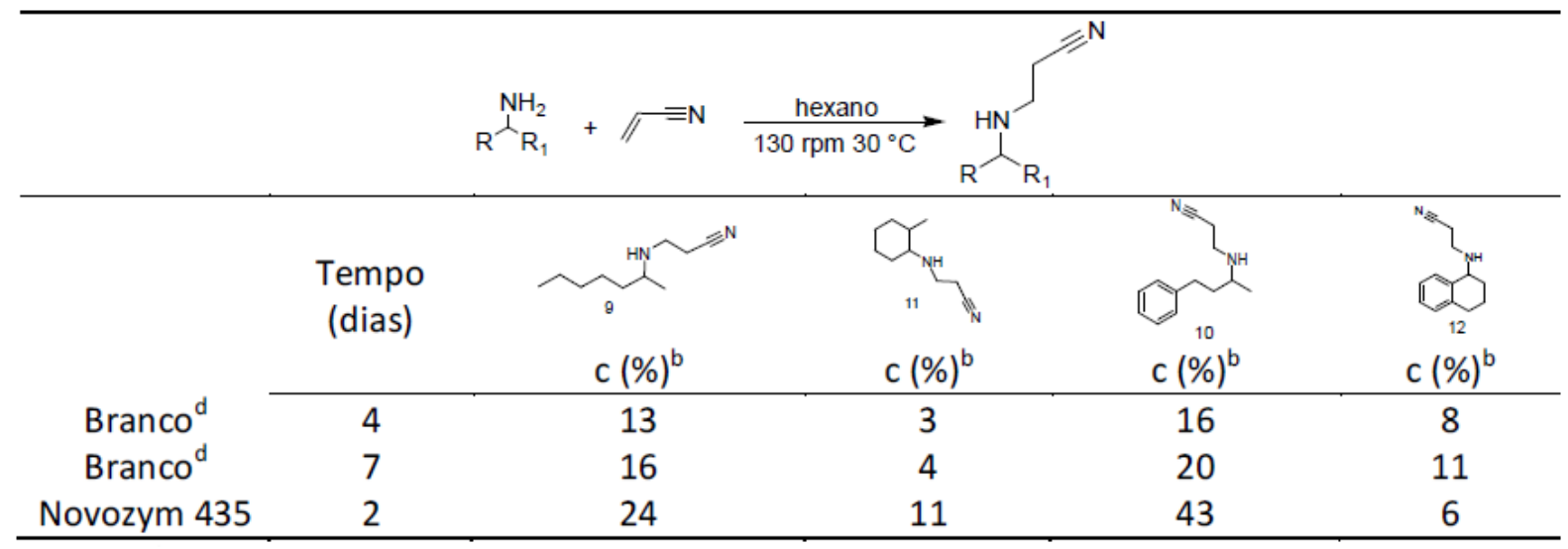

a condições reacionais: solvente $(2 \mathrm{~mL})$, lipase $(2 \mathrm{mg})$, amina $(70 \mathrm{mg}-0,6$ mmol), acrilonitrila $(0,1 \mathrm{~mL}-1,5 \mathrm{mmol})$. Agitação orbital $\left(130 \mathrm{rpm}\right.$ a $\left.30^{\circ} \mathrm{C}\right)$.

${ }^{\mathrm{b}} \mathrm{c}=$ conversão determinada por CG-FID (coluna DB-5).

d ausência de lipase.

Tabela 3.2: Adição de Michael entre 2-amino-heptano (1) e acrilonitrila - comparação da reação realizada em agitação orbital e micro-ondas

\begin{tabular}{|c|c|c|c|c|c|c|c|c|}
\hline & 1 & - & $\begin{array}{r}\text { hexanc } \\
130 \mathrm{rpm} \\
\mathrm{MO}\end{array}$ & $\begin{array}{l}{ }^{\circ} \mathrm{g} / 3 \mathrm{~min} \\
/ 30 \mathrm{~s}\end{array}$ & 9 & $\omega \geqslant$ & & \\
\hline \multirow{3}{*}{ Lipases } & \multicolumn{4}{|c|}{ Agitador Orbital $^{\mathrm{a}}$} & \multicolumn{4}{|c|}{ Micro-ondas ${ }^{b}$} \\
\hline & \multicolumn{2}{|c|}{ Hexano } & \multicolumn{2}{|c|}{ Água } & \multicolumn{2}{|c|}{ Hexano } & \multicolumn{2}{|c|}{ Água } \\
\hline & Tempo (horas) & c (\%) & $\begin{array}{c}\text { Tempo } \\
\text { (min.) }\end{array}$ & c (\%) & Tempo (min.) & c (\%) & Tempo (s) & c (\%) \\
\hline Branco & 24 & 0 & 3 & 60 & 5 & 0 & 30 & 73 \\
\hline $\mathrm{CCL}$ & 24 & 22 & 3 & 56 & 5 & 1 & 30 & 41 \\
\hline CRL & 24 & 15 & 3 & 23 & 5 & 0 & 30 & 30 \\
\hline HPL & 24 & 32 & 3 & 55 & 5 & 0 & 30 & 24 \\
\hline PPL & 24 & 15 & 3 & 55 & 5 & 0 & 30 & 38 \\
\hline Novozym 435 & 24 & 17 & 3 & 53 & 5 & 0 & 30 & 84 \\
\hline
\end{tabular}

a condições reacionais: solvente $(2 \mathrm{~mL})$, lipase (10.450 unidades catalíticas), amina 1 (57,6 mg - 0,5 mmol), acrilonitrila $(0,1 \mathrm{~mL})$, agitação orbital de 130 $\mathrm{rpm}$ a $30^{\circ} \mathrm{C}$.

b condições reacionais: solvente $(2 \mathrm{~mL})$, lipase (10.450 unidades catalíticas), amina 1 (57,6 $\mathrm{mg}-0,5 \mathrm{mmol})$, acrilonitrila $(0,1 \mathrm{~mL})$, agitação magnética em $\mathrm{MO}$ a $40^{\circ} \mathrm{C}$ (potência máxima $150 \mathrm{~W}$ ). 
Em todos os experimentos realizados com as diferentes lipases sob o efeito da irradiação $\mathrm{MO}$, em hexano, praticamente nenhuma reação ocorreu possivelmente devido a falta de sinergismo entre $\mathrm{MO}$ e o solvente hexano bem como a solubidade do substrato. Enquanto que em água sob irradiação MO obtiveram-se rendimentos satisfatórios do aduto de Michael 9 (Tabela 3.2). Inclusive na reação na presença de lipase imobilizada de CAL-B a conversão obtida foi de $84 \%$, cujo resultado foi superior ao controle (sem lipase) que foi de 73\% (Tabela 3.2). Neste estudo observou-se que a reação em hexano sob irradiação MO não levou a formação de nenhum produto com todas as lipases utilizadas. No entanto, as reações em hexano e em água ocorreram de forma satisfatória em agitação orbital. Destaca-se que neste caso a reação em hexano não ocorreu na ausência de lipases. Enquanto que em água o resultado na ausência de lipase foi superior aos obtidos na agitação orbital.

De certa forma não é trivial avaliar quais são os fatores que favorecem ou desfavorecem as reações aqui estudadas, uma vez que os resultados não são comparáveis e vários fatores podem influenciar o desempenho destas reações.

Na literatura (Souza et al., 2009) é relatada uma eficiente atividade catalítica das lipases na reação de adição de Michael entre aminas primárias e acrilonitrila quando o solvente utilizado foi tolueno em agitação orbital de 250 rpm.

Pelo fato das reações em hexano sob agitação orbital terem sido favorecidas em relação às reações sob irradiação micro-ondas, as quais não fornecem produtos, observa-se um forte efeito da irradiação MO nestas reações bem como o papel das lipases. Talvez, pelo fato do hexano não absorver a irradiação MO, a reação de adição de Michael nestas condições possa ter sido dificultada.

Destaca-se também que em hexano, sob agitação orbital, a presença das lipases foi crucial para promover a reação de adição de Michael. Como pode ser observado na Tabela 3.3, todas as lipases catalisaram a reação de Michael quando foram realizadas sob agitação orbital e em hexano como solvente. Interessantemente foi que as reações em meio aquoso sob agitação orbital ocorrem muito melhor que em hexano, inclusive a reação na ausência de lipase em água forneceu a melhor conversão. Portanto, através destes estudos concluise que o solvente prótico promoveu espontaneamente a adição de Michael, enquanto no solvente aprótico (hexano) a adição de Michael foi dificultada.

Deve-se destacar que o hexano é um solvente comumente usado em reações de esterificação e transesterificação com lipases frente a diferentes compostos orgânicos. Porém, a reação de adição de Michael não é usualmente catalisada por lipases em sistemas biológicos.

Esta dificuldade se dá possivelmente porque lipases possuem uma superfí- 
cie hidrofóbica que frequentemente contém uma região no formato de "tampa" que é associada ao sítio ativo (Figura 3.14). Acredita-se que essa superfície associa-se com a fase hidrofóbica na interface entre sistemas bifásicos. A ativação interfacial de lipases resulta primeiramente em mudanças na conformação desta "tampa" que cerca o sítio ativo em conformidade com as condições do solvente. Isto expõe o sítio ativo e providencia uma superfície hidrofóbica para interação com o substrato que acessa o sítio ativo mais facilmente (Saifuddin \& Raziah, 2008).

Figura 3.14: Estrutura da lipase de Candida rugosa

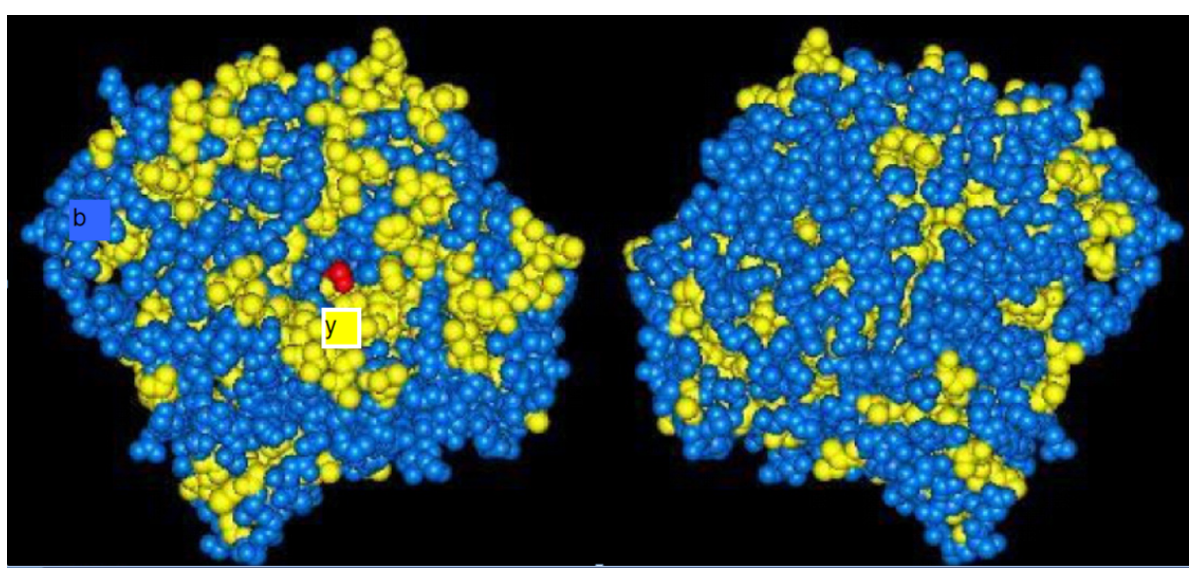

Em amarelo estão os aminoácidos hidrofóbicos, em azul todos os outros aminoácidos e em vermelho o sítio ativo. Note o anel hidrofóbico ao redor do sítio ativo. Fonte: SAIFUDDIN, N. e RAZIAH, A. (2008). Enhancement of lipase enzyme activity in non-aqueous media through a rapid three phase partitioning and microwave irradiation. Journal of Chemistry, 5(4), 864-871.

Observou-se que em hexano a reação ocorreu melhor sob agitação orbital e em água a reação FOI realizada sob o efeito de MO. Entretanto, em ambos os casos é possivel que as reações ocorram sem a influência da lipase. Tal evidência foi observada pela medida de rotação óptica do aduto 9 obtido na presença da lipase CAL-B, pois não promoveu o desvio da luz polarizada no polarímetro. O rendimento isolado do aduto 9 foi de $77 \%$. Em geral as reações de adição de Michael catalisadaS por lipases não são seletivas como demonstrado por Cai (2006) na adição de Michael da cicloexanona e acetilacetona (Figura 3.15) (Cai et al., 2006).

As reações de adição de Michael na presença das lipases CRL, CCL, HPL e PPL apresentaram desempenho inferior à CAL-B. Estas lipases não imobilizadas geralmente têm menor atividade catalítica devido à diminuição da flexibilidade molecular da enzima em pó suspensa em meios com pouca água, bem como em hexano. Essa baixa atividade ocorre devido à rigidez da proteína durante o processo de liofilização que pode retirar as moléculas de água 
estruturais e que são responsáveis pela conformação e atividade catalítica (Saifuddin \& Raziah, 2008; Réjasse et al., 2004; ?).

Figura 3.15: Adição de Michael da ciclohexanona e acetilacetona na presença de lipases

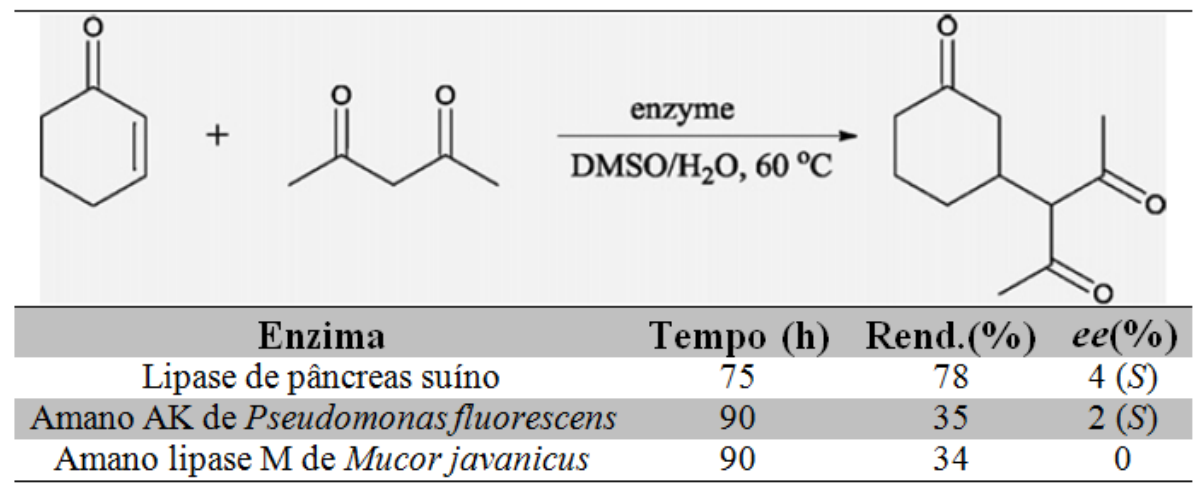

Fonte: CAI, J.; GUAN, Z.; HE, Y. (2011). The lipase-catalyzed asymmetric C-C Michael addition. Journal of Molecular Catalysis B: Enzymatic, 68 (3), 240244 .

Assim, dando continuidade aos estudos realizaram-se as reações de adição de Michael com as aminas 1-4 em água sob agitação orbital e sob o efeito de irradiação MO. Os resultados obtidos estão na Tabela 3.3.

A 2-metil-cicloexilamina (3) e a 1-metil-3-fenilpropilamina (2) forneceram bons rendimentos para o aduto de Michael tanto em agitação orbital, quanto em MO. A naftilamina (4) forneceu a mesma conversão para a reação sem e com lipase (MO), com exceção do experimento realizado na presença da lipase CAL-B em MO, onde se obteve uma excelente conversão de 63\% quando comparada as demais enzimas. Para a 2-amino-heptano (1) os resultados obtidos demonstraram uma elevada conversão (84\%) quando a reação foi realizada na presença de lipase CAL-B e MO fornecendo um rendimento de $81 \%$.

Segundo Li et al. (2010), as ligações hidrogênio, responsáveis pela conformação do sítio ativo da enzima, não podem ser formadas na presença de solventes polares como a água, pois tais solventes interagem intensivamente com o sítio ativo. A ausência das ligações hidrogênio altera a distância entre os resíduos de aminoácidos interferindo assim na atividade catalítica da lipase. O que pode explicar a ausência de atividade de algumas lipases observada nestes estudos quando foi utilizada a água como solvente.

Uma maior estabilidade da lipase CAL-B ocorre possivelmente devido à imobilização da enzima, onde ocorrem ligações covalentes entre a enzima e o suporte que tornam a estrutura da proteína rígida. Isto reduz a mudança conformacional ligada à inativação da enzima e um aumento da sua estabilidade (Mateo et al., 2007). Portanto, seria esperado que as reações com a lipase 
Tabela 3.3: Adição de Michael entre aminas primárias (1-4) e acrilonitrila - comparação da reação realizada em agitador orbital e micro-ondas

\begin{tabular}{|c|c|c|c|c|c|c|c|c|}
\hline \multirow[t]{4}{*}{ Lipases } & & & & N & \multicolumn{2}{|c|}{10} & \\
\hline & $\mathrm{AO}^{\mathrm{a}}$ & $\mathrm{MO}^{\mathrm{b}}$ & $\mathrm{AO}^{\mathrm{a}}$ & $\mathrm{MO}^{\mathrm{b}}$ & $\mathrm{AO}^{\mathrm{a}}$ & $\mathrm{MO}^{\mathrm{b}}$ & $\mathrm{AO}^{\mathrm{a}}$ & $\mathrm{MO}^{\mathrm{b}}$ \\
\hline & $3 \mathrm{~min}$ & $30 \mathrm{~s}$ & $3 \min$ & $30 \mathrm{~s}$ & $3 \mathrm{~min}$ & $30 \mathrm{~s}$ & $3 \min$ & $30 \mathrm{~s}$ \\
\hline & $c(\%)$ & $c(\%)$ & $c(\%)$ & $c(\%)$ & $c(\%)$ & $c(\%)$ & $c(\%)$ & $c(\%)$ \\
\hline Branco & 60 & 73 & 48 & 37 & 49 & 58 & 18 & 9 \\
\hline CCL & 56 & 41 & 44 & 39 & 41 & 21 & 5 & 5 \\
\hline CCR & 23 & 30 & 43 & 45 & 43 & 31 & 2 & 10 \\
\hline HPL & 55 & 24 & 39 & 38 & 54 & 36 & 8 & 10 \\
\hline PPL & 55 & 38 & 43 & 57 & 44 & 39 & 9 & 11 \\
\hline CAL-B & 53 & 84 & 42 & 37 & 44 & 57 & 15 & 63 \\
\hline
\end{tabular}

a condições reacionais: água ( $2 \mathrm{~mL}$ ), lipase (10.450 unidades catalíticas), aminas 1-4 $(0,5 \mathrm{mmol})$, acrilonitrila $(0,1 \mathrm{~mL})$, agitação orbital $\left(130 \mathrm{rpm}\right.$ a $30^{\circ} \mathrm{C}$ por 3 min.).

b condições reacionais: água ( $1 \mathrm{~mL}$ ), lipase (10.450 unidades catalíticas), aminas 1-4 (0,5 mmol), acrilonitrila $(0,1 \mathrm{~mL})$, agitação magnética em $\mathrm{MO}$ a $40^{\circ} \mathrm{C}$ (potência máxima $150 \mathrm{~W}$ ) por $30 \mathrm{~s}$.

imobilizada fornecessem melhores resultados.

Cai et al. (2006) demonstraram que o hexano é um bom solvente para a reação catalisada por lipases, obtendo-se 100\% de conversão na reação entre imidazol e metil acrilato na ausência de irradiação MO. Um dos fatores que podem ter causado essa diferença nos resultados obtidos neste trabalho quando comparados aos de Torre et al. (2004) é que a temperatura foi de $30^{\circ} \mathrm{C}$, enquanto a relatada no trabalho foi de $50^{\circ} \mathrm{C}$.

A principal diferença entre nossos estudos e os apresentados por Souza et al. (2009) e Torre et al. (2004) está na estrutura dos substratos utilizados. Torre et al. (2004) relata apenas o uso de aminas secundárias e Souza et al. (2009) utilizam 4 aminas sendo uma primária benzílica e outras 3 secundárias (Figura 3.16). Todas as aminas estudadas por nós foram primárias. Ainda pode ocorrer uma possivel inibição da enzima pelo produto da reação o que impede a formação do aduto catalisado pela lipase ou os substratos nucleofílicos interagirem com a parte proteica da enzima.

Para nosso conhecimento os adutos de Michael 9, 10, 11 e 12 obtidos neste trabalho foram sintetizados pela primeira vez com a metodologia relatada, sendo que os adutos 9,10 e 11 não foram descritos na literatura. 
Figura 3.16: Compostos utilizados por Souza et al. (2009) e Torre et al. (2004) em reações de adição de Michael

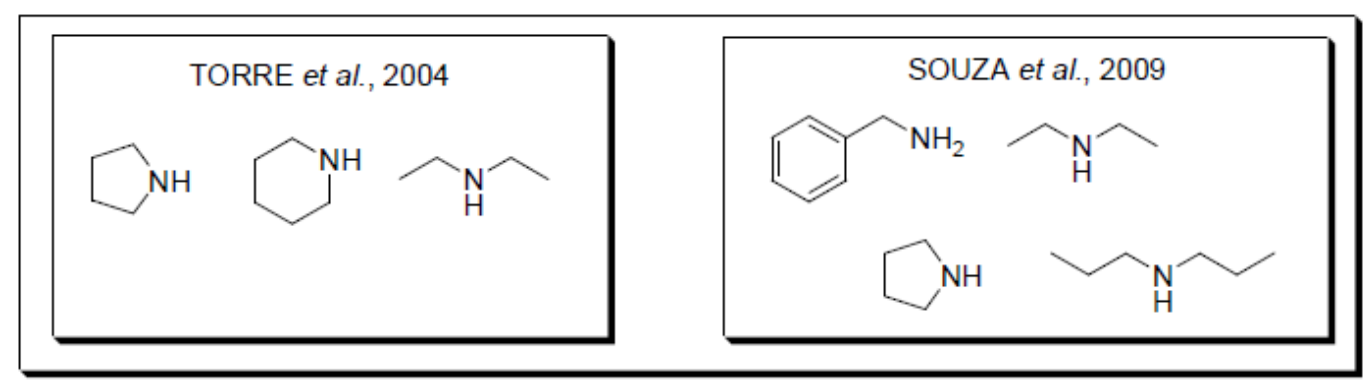

\section{Caracterização estrutural dos compostos 9-12}

Os espectros de RMN de ${ }^{1} \mathrm{H}$ e $\mathrm{RMN}$ de ${ }^{13} \mathrm{C}$ dos compostos 9-12 são apresentados em Anexo.

A 3-[(1-metil-hexil)amino]propanonitrila 9 foi isolada como um óleo amarelo. Pelos dados adquiridos por HRMS observou-se um pico com $\mathrm{m} / \mathrm{z}$ 169,17119 $\left[\mathrm{M}+\mathrm{H}^{+}\right]$, correspondente à fórmula molecular $\mathrm{C}_{10} \mathrm{H}_{20} \mathrm{~N}_{2}$ sendo também este o pico base (100\%).

No espectro de IV foi observada uma banda fraca na região de $3315 \mathrm{~cm}^{-1}$ referente ao estiramento axial da ligação C-NH, o que permitiu sugerir a presença da amina secundária. Uma banda média na região de $2246 \mathrm{~cm}^{-1}$ referente ao estiramento axial da ligação $\mathrm{C} \equiv \mathrm{N}$ não conjugada, o que permitiu sugerir a presença de um grupo ciano.

No espectro de RMN de ${ }^{13} \mathrm{C}$ foram observadas 9 linhas espectrais, todas correspondentes a carbonos $s p^{3}$. A adição de Michael foi também confirmada pela presença de um carbono $s p$ em $\delta 118$ (C-10) referente ao grupo ciano. As atribuições completas dos valores de deslocamento químico dos hidrogênios e carbonos são apresentados na Tabela 3.4. Os espectros de RMN encontram-se no Apêndice A.2. 
Tabela 3.4: $\mathrm{RMN}$ de ${ }^{1} \mathrm{H}(300 \mathrm{MHz})$ e $\mathrm{RMN}$ de ${ }^{13} \mathrm{C}(75 \mathrm{MHz})$ do composto $9\left(\mathrm{CDCl}_{3}\right.$, $\delta$ em ppm, $J$ em $\left.\mathrm{Hz}\right)$

\begin{tabular}{|c|c|c|}
\hline & 1 & $\underbrace{2}_{5}$ \\
\hline$\# C$ & $8 \mathrm{C}$ & $\delta \mathrm{H}$ \\
\hline 1 & 13,9 & $0,85(1 \mathrm{H}, \mathrm{t}, J=6,93)$ \\
\hline 2 & 22,5 & $1,25(6 \mathrm{H}, \mathrm{m})$ \\
\hline 3 & 31,9 & $1,25(6 \mathrm{H}, \mathrm{m})$ \\
\hline 4 & 325,5 & $1,25(6 \mathrm{H}, \mathrm{m})$ \\
\hline 5 & 36,9 & $1,40(2 \mathrm{H}, \mathrm{m})$ \\
\hline 6 & 52,4 & $12,88(1 \mathrm{H}, \mathrm{m})$ \\
\hline 7 & 20,2 & $1,00(3 \mathrm{H}, \mathrm{d}, J=6,24)$ \\
\hline 8 & 42,3 & $2,62(2 \mathrm{H}, \mathrm{m})$ \\
\hline 9 & 19,0 & $2,45(2 \mathrm{H}, \mathrm{t}, J=6,54)$ \\
\hline 10 & 118,7 & - \\
\hline
\end{tabular}

A 3-[(3-metil-3-fenil-propil)amino]propanonitrila 10 foi isolada como um óleo amarelo. Pelos dados adquiridos por HRMS observou-se um pico com $m / z 203,15495\left[\mathrm{M}+\mathrm{H}^{+}\right]$, correspondente à fórmula molecular $\mathrm{C}_{13} \mathrm{H}_{18} \mathrm{~N}_{2}$ sendo também este o pico base (100\%).

No espectro de IV foi observada uma banda fina na região de $3028 \mathrm{~cm}^{-1}$ referente ao estiramento axial da ligação $\mathrm{C}-\mathrm{NH}$, o que permitiu sugerir a presença da amina secundária. Uma banda média na região de $2246 \mathrm{~cm}^{-1}$ referente ao estiramento axial da ligação $\mathrm{C} \equiv \mathrm{N}$ não conjugada, o que permitiu sugerir a presença do grupo ciano.

No espectro de $\mathrm{RMN}$ de ${ }^{13} \mathrm{C}$ foram observadas 6 linhas espectrais, todas correspondentes a carbonos $s p^{3}$ e 6 linhas espectrais referentes a carbonos $s p^{2}$. A adição de Michael foi também confirmada pela presença de um carbono $s p$ em $\delta 118$ (C-13) referente ao grupo ciano. As atribuições completas dos valores de deslocamento químico dos hidrogênios e carbonos são apresentados na Tabela 3.5. Os espectros de RMN encontram-se no Apêndice A.2. 
Tabela 3.5: $\mathrm{RMN}$ de ${ }^{1} \mathrm{H}(300 \mathrm{MHz})$ e $\mathrm{RMN}$ de ${ }^{13} \mathrm{C}(75 \mathrm{MHz})$ do composto $10\left(\mathrm{CDCl}_{3}\right.$, $\delta$ em ppm, $J$ em $\left.\mathrm{Hz}\right)$

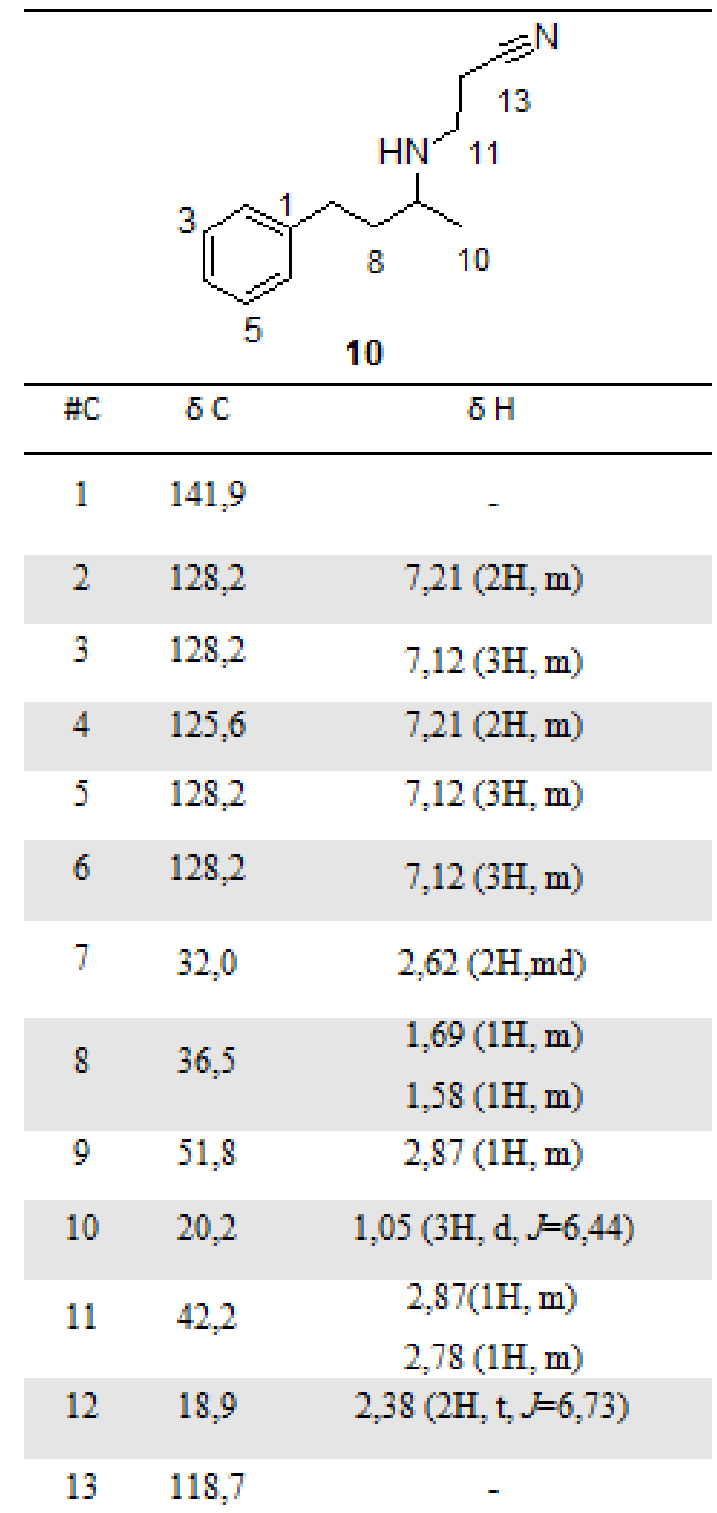

A cis-3-[(2-metil ciclo-hexil)amino]propanonitrila 11 foi isolada como um óleo amarelo. Pelos dados adquiridos por HRMS observou-se um pico com $m / z 167,15540\left[\mathrm{M}+\mathrm{H}^{+}\right]$, correspondente à fórmula molecular $\mathrm{C}_{10} \mathrm{H}_{18} \mathrm{~N}_{2}$ sendo também este o pico base (100\%).

No espectro de IV foi observada uma banda fraca na região de $3250 \mathrm{~cm}^{-1}$ referente ao estiramento axial da ligação C-NH, o que permitiu sugerir a presença da amina secundária. Uma banda média na região de $2246 \mathrm{~cm}^{-1}$ referente ao estiramento axial da ligação $\mathrm{C} \equiv \mathrm{N}$ não conjugada, permitiu sugerir a presença do grupo ciano.

No espectro de $\mathrm{RMN}$ de ${ }^{13} \mathrm{C}$ foram observadas 6 linhas espectrais, todas correspondentes a carbonos $s p^{2}$. A adição de Michael foi também confirmada 
pela presença de um carbono sp em $\delta 118$ (C-13) referente ao grupo nitrila. As atribuições completas dos valores de deslocamento químico dos hidrogênios e carbonos são apresentados na Tabela 3.6.

Tabela 3.6: $\mathrm{RMN}$ de ${ }^{1} \mathrm{H}(300 \mathrm{MHz})$ e $\mathrm{RMN}$ de ${ }^{13} \mathrm{C}(75 \mathrm{MHz})$ do composto $11\left(\mathrm{CDCl}_{3}\right.$, $\delta$ em ppm, $J$ em $\left.\mathrm{Hz}\right)$.

\begin{tabular}{|c|c|c|}
\hline & & ${ }_{10}^{8_{H}^{N}}$ \\
\hline$\# \mathrm{C}$ & $8 \mathrm{C}$ & $\delta \mathrm{H}$ \\
\hline 1 & 62,0 & $2,56(1 \mathrm{H}, \mathrm{m})$ \\
\hline 2 & 37,7 & $1,98(1 \mathrm{H}, \mathrm{m})$ \\
\hline 3 & 32,2 & $1,40(8 \mathrm{H}, \mathrm{m})$ \\
\hline 4 & 25,6 & $1,40(8 \mathrm{H}, \mathrm{m})$ \\
\hline 5 & 25,2 & $1,40(8 \mathrm{H}, \mathrm{m})$ \\
\hline 6 & 34,3 & $1,40(8 \mathrm{H}, \mathrm{m})$ \\
\hline 7 & 13,8 & $0,93(3 \mathrm{H}, \mathrm{d}, J=6,44)$ \\
\hline 8 & 41,9 & $\begin{array}{l}2,96(1 \mathrm{H}, \mathrm{m}) \\
2,81(1 \mathrm{H}, \mathrm{m})\end{array}$ \\
\hline 9 & 19,0 & $2,43(2 \mathrm{H}, \mathrm{m})$ \\
\hline 10 & 118,7 & - \\
\hline
\end{tabular}

As atribuições referenm-se a estrutura do composto cis.

A 3-(1,2,3,4-tetra-hidronaftaleno-1-amino)propanonitrila 12 foi isolada como um óleo marrom. O espectro de massas deste composto não foi obtido devido a sua degradação no injetor do espectrômetro.

No espectro de IV foi observada uma banda fraca na região de $3329 \mathrm{~cm}^{-1}$ referente ao estiramento axial da ligação C-NH, o que permitiu sugerir a presença da amina secundária. Uma banda média na região de $2246 \mathrm{~cm}^{-1}$ referente ao estiramento axial da ligação $\mathrm{C} \equiv \mathrm{N}$ não conjugada, permitiu sugerir a presença do grupo ciano.

No espectro de $\mathrm{RMN}$ de ${ }^{13} \mathrm{C}$ foram observadas 6 linhas espectrais, todas 
correspondentes a carbonos $s p^{3}$ e 6 linhas espectrais referentes a carbonos $s p^{2}$. A adição de Michael foi também confirmada pela presença de um carbono $s p$ em $\delta 118$ (C-13) referente ao grupo ciano. As atribuições completas dos valores de deslocamento químico dos hidrogênios e carbonos são apresentados na Tabela 3.7. Os espectros de RMN encontram-se no Apêndice A.2.

Tabela 3.7: $\mathrm{RMN}$ de ${ }^{1} \mathrm{H}(300 \mathrm{MHz})$ e $\mathrm{RMN}$ de ${ }^{13} \mathrm{C}(75 \mathrm{MHz})$ do composto $12\left(\mathrm{CDCl}_{3}\right.$, $\delta$ em ppm, $J$ em $\left.\mathrm{Hz}\right)$

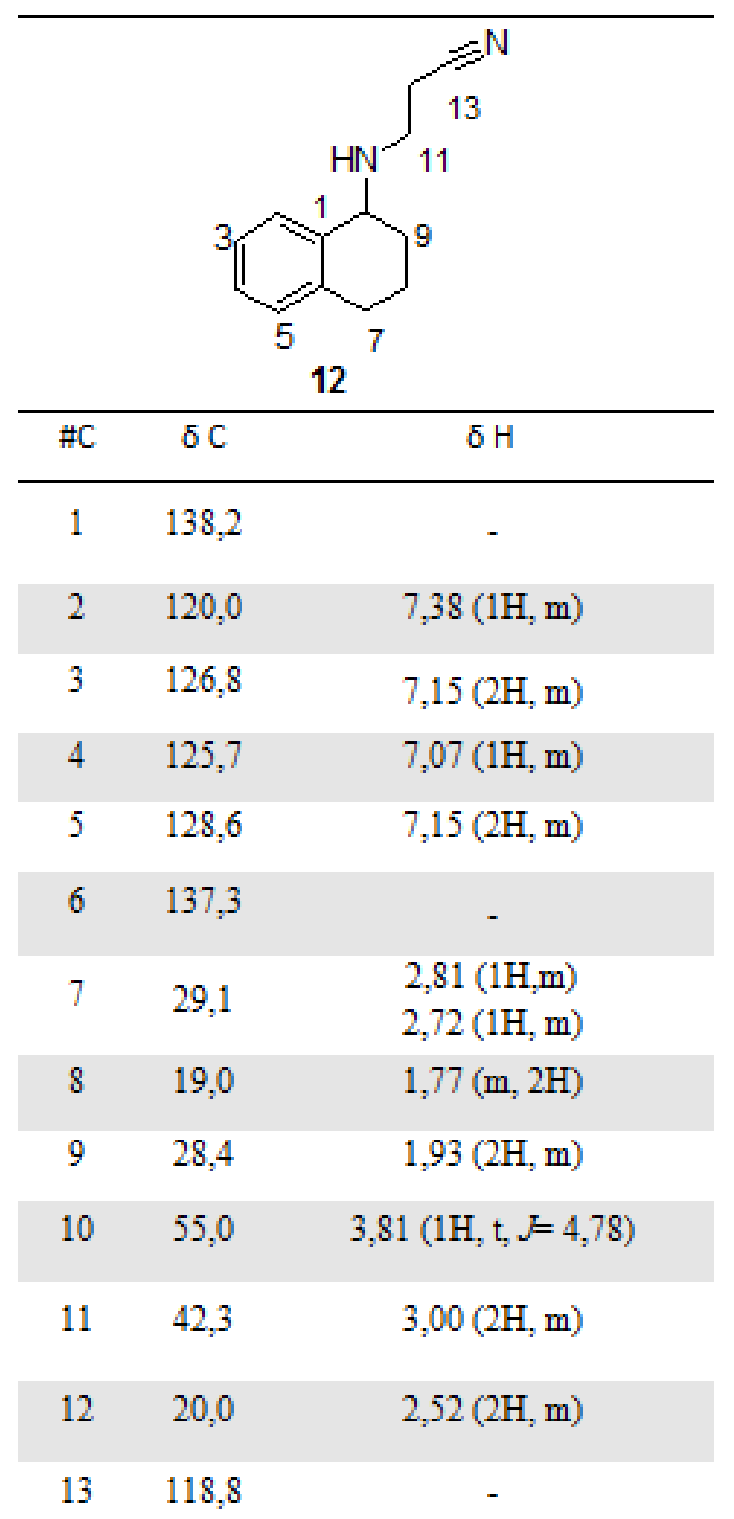




\subsection{Conclusões}

Analisando os resultados obtidos nas reações de adição de Michael com aminas primárias (1-4), observou-se que a presença da enzima CAL-B no meio reacional promoveu melhores conversões com tempo reacional inferior (2 dias) ao da reação não catalisada que foi de 7 dias. Para a (3-heptan-2-il amino) propanonitrila (9) a conversão foi de $16 \%$ para $24 \%$ na presença de CAL-B, para a 3-(4-fenil butan-2-il amino) propanonitrila (10) foi de 20\% para 43\%, para a 3-(2-metil ciclo-hexil amino) propanonitrila (11) foi de 4\% para 11\% e para a 3-(1,2,3,4-tetra-hidronaftalen-1-il amino) propanonitrila (12) foi de $11 \%$ de conversão para $6 \%$ usando a CAL-B.

Utilizando a água como solvente a reação de forma espontânea foi favorecida fornecendo maior rendimento dos produtos e demonstrando ser o melhor solvente para a reação em questão. No experimento para avaliação do solvente foi utilizada a 2-amino heptano que na prensença de água sob agitação orbital por $24 \mathrm{~h}$ apresentou uma conversão de 60\% sendo que o mesmo experimento tendo o hexano como solvente não teve conversão da amina em seu respectivo aduto de Michael. O mesmo tipo de resultado foi observado quando a adição se deu na presença de micro-ondas onde a conversão foi de $73 \%$ em água e nula em hexano.

Quando realizada sob o efeito da radiação de micro-ondas a adição de Michael propiciou maior conversão do material de partida no aduto de Michael em tempo 6 vezes menor, comprovando a contribuição das micro-ondas na obtenção de produto. Para o aduto 9 sob agitação orbital a conversão era de 60\% e passou a ser de 73\% na presença de MO e para o aduto 10 passou de 49\% em agitação orbital para 58\% sob MO. No caso dos adutos 11 e 12 as micro-ondas apresentaram melhora na conversão quando na presença de lipases, para o aduto $\mathbf{1 1}$ utilizando lipase de pâncreas suíno a conversão foi de $43 \%$ para 57\% sob MO e para o aduto 12 na presença de CAL-B foi de $15 \%$ para 63\% quando utilizada irradiação MO.

As enzimas não imobilizadas tiveram menor atividade catalítica em meios orgânicos, uma possibilidade é que a ausência de água não favoreça a reação.

Finalmente a adição de Michael sob o efeito de irradiação MO forneceu uma metodologia eficiente na obtenção de novas moléculas contendo ligações C-N. 


\section{CAPÍTULO}

\section{Clonagem, expressão e purificação de álcool desidrogenase de $B$. subtilis para redução de cetonas}

Este capítulo teve a orientação da Prof $^{a}$ Dr $^{a}$ Fernanda Canduri do Grupo de Biologia Molecular e Bioquímica (IQSC-USP).

\section{1 Materiais e Métodos}

\subsubsection{Protocolo de extração do DNA genômico bacteriano}

O DNA genômico bacteriano foi extraído segundo protocolo fornecido para o Kit AxyPrep DNA Genômico Bacteriano Miniprep da AXYGEN. Este Kit é adequado para o rápido isolamento de $20 \mathrm{mg}$ de DNA genômico de $1,0 \times 10^{9}$ células bacterianas. A purificação do DNA é predominantemente $\geq 30 \mathrm{~Kb}$ de comprimento e é adequado para uma grande variedade de aplicações como por exemplo a reação de PCR, obtendo DNA altamente purificado.

As etapas do protocolo são dadas na Figura 4.1.

\subsubsection{Construção dos oligonucleotídeos iniciadores para PCR}

Os oligonucleotídeos iniciadores (primers) foram construídos a partir das sequências de DNA da ADH identificada no banco de dados Genbank (código 
Clonagem, expressão e purificação de álcool desidrogenase de B. subtilis para 74 redução de cetonas

Figura 4.1: Etapas do protocolo de extração do DNA genômico bacteriano

Adicionar $150 \mu \mathrm{L}$ do tampão S contendo RNase A
Adicionar $20 \mu \mathrm{L}$ de lisozima
Adicionar $30 \mu \mathrm{L}$ de EDTA 0,25 M
Adicionar $450 \mu \mathrm{L}$ do tampão G-A
Adicionar $400 \mu \mathrm{L}$ do tampão B-B
Adicionar $1 \mathrm{~mL}$ do tampão DV
Repetir a extração com tampão DV

Adicionar $400 \mu \mathrm{L}$ do tampão BV

Adicionar $500 \mu \mathrm{L}$ do tampão W1

Adicionar $700 \mu \mathrm{L}$ do tampão W2

Repetir a lavagem com tampão W2

Adicionar 100-200 $\mu \mathrm{L}$ do eluente
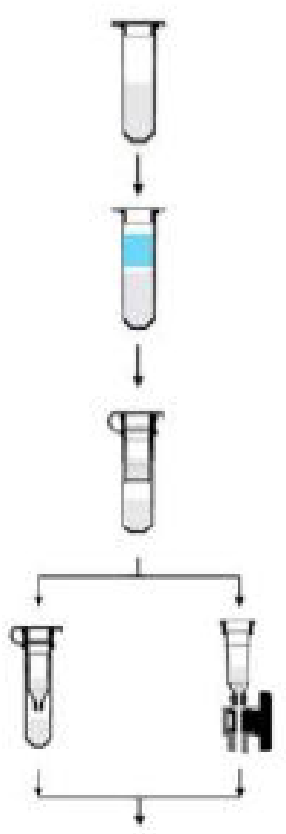

晋
Lise

Partição de fases

Filtração

Ligação

Lavagem

Eluição

GI 1934622) inserindo-se sítios para a enzima de restrição NdeI no iniciador 5' na região do códon de iniciação do DNA alvo, e EcoRI no iniciador 3' na região do códon de terminação do DNA alvo.

\section{1.3 Protocolo para diluição dos primers}

A diluição dos primers liofilizados foi realizada a fim de obter-se uma solução estoque de concentração de $100 \mu \mathrm{M}$. A partir deste estoque, os primers foram diluídos para a concentração de $10 \mu \mathrm{M}$ e essa foi utilizada nos demais experimentos.

\subsubsection{Reação em cadeia da polimerase (PCR)}

$\mathrm{O}$ fragmento de DNA referente à $\mathrm{ADH}$ foi amplificado por meio da reação em cadeia da polimerase ("polymerase chain reaction" - PCR), utilizando a enzima de alta fidelidade High-Fidelity PCR Enzyme Mix (Fermentas) e os oligonucleotídeos específicos sintetizados. Nas reações de amplificação foram utilizados os oligonucleotídeos (primers) de concentração $10 \mu \mathrm{M}$, o DNA bacteriano, DNA 
polimerase, tampão 10X High Fidelity PCR com $15 \mathrm{mM} \mathrm{MgCl}_{2}$ e água deionizada e autoclavada num volume final de $50 \mu \mathrm{L}$.

O programa utilizado consistiu de 35 ciclos de amplificação, controlados por um gradiente de temperatura. Deste modo o volume final foi dividido em cinco tubos, com variação de temperatura (60,5;61,0;61,4;62,0;62,8 ${ }^{\circ} \mathrm{C}$ ), referente ao gradiente escolhido. Para promover as reações de amplificação, foi utilizado o termociclador modelo MyCycler Thermal Cycler (Bio-Rad).

O produto de PCR foi purificado usando o kit QIAquick ${ }^{\circledR}$ Gel Extraction kit (QIAGEN) para realizar a subclonagem no vetor de propagação $p G E M-T$ easy (PROMEGA).

\subsubsection{Eletroforese em gel de agarose}

O DNA foi analisado através de eletroforese em gel de agarose contendo $8 \mathrm{mg} / \mathrm{mL}$ de agarose em tampão TAE: Tris-Acetato $40 \mathrm{mmol} / \mathrm{L}$ e EDTA (ácido etilenodiaminotetracético) $1 \mathrm{mmol} / \mathrm{L}(\mathrm{pH} \mathrm{8,0)}$. Após a aplicação do DNA no gel, este foi submetido a uma corrente elétrica de 110 Volts, por aproximadamente 30 minutos. Em seguida o gel foi incubado em tampão TAE, contendo 0,1 $\mu \mathrm{g} / \mathrm{mL}$ de brometo de etídio, por 15 minutos, e visualizado no Bio-Imaging Systems MiniBIS Pro acoplado a um computador, para permitir o registro das imagens dos géis.

\subsubsection{Determinação da concentração de DNA}

A determinação da concentração de DNA foi feita através da comparação entre a intensidade da banda de DNA marcada com brometo de etídio e a intensidade de bandas padrão de DNA (GeneRuler ${ }^{T M}$ Kb DNA Ladder - Fermentas), e também com o uso do equipamento Thermo Scientific NanoDrop ${ }^{\text {TM }}$ 1000 Spectrophotometer, localizado no laboratório do Grupo de Biofísica Molecular "Sérgio Mascarenhas" sob responsabilidade da Profa. Dra. Ana Paula Ulian de Araújo (IFSC- USP).

\subsubsection{Extração do produto de PCR}

O fragmento de DNA amplificado foi extraído do gel de agarose segundo o protocolo fornecido para o QIAquick $^{\circledR}$ Gel Extraction kit (QIAGEN) . Este Kit é adequado para a extração de gel ou limpeza de $10 \mu \mathrm{g}$ de DNA com tamanho entre $70 \mathrm{pb}$ até $10 \mathrm{~kb}$. Os fragmentos purificados com o kit estão prontos para uso direto em todas as aplicações incluindo sequenciamento, ligação e transformação, digestão restritiva, PCR, entre outras. 
As etapas do protocolo são dadas na Figura 4.2:

Figura 4.2: Etapas do protocolo de extração do produto de PCR

\section{Visão Global do protocol:}

\begin{abstract}
Adicionar 3 volumes de tampăo QG Incubar a $50^{\circ} \mathrm{C}$ por $10 \mathrm{~min}$

Checar se a cor da mistura é amarela

Adicionar 1 volume de isopropanol
\end{abstract}

Adicionar $500 \mu \mathrm{L}$ de tampăo QG

Adicionar $750 \mu \mathrm{L}$ de tampăo PE

Adicionar $50 \mu \mathrm{L}$ de tampăo EB para eluir o DNA

\section{Reaçāo de PCR}

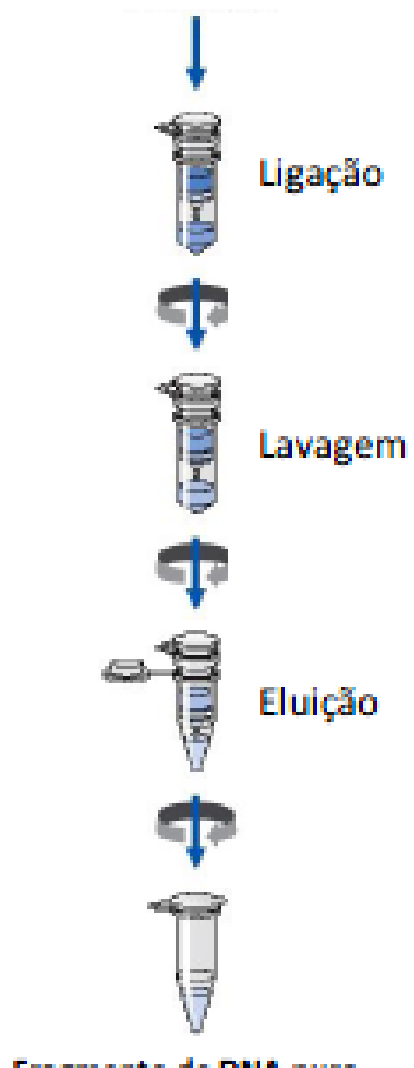

\section{1.8 Vetores}

Vetor de clonagem

Após o isolamento de uma informação genética, os fragmentos de DNA obtidos pela clivagem com enzimas de restrição devem ser inseridos numa outra molécula de DNA, capaz de amplificar esta informação genética em centenas de cópias. Este processo de amplificação é obtido através do uso de moléculas de DNA que são chamados de vetores de clonagem molecular.

Vetores de clonagem são pequenas moléculas de DNA dupla fita, contendo os elementos necessários para a sua replicação e pelo menos um gene que confere resistência a antibiótico. Estas moléculas variam de 5 a 400 quilobases e comumente estão presentes em duas ou mais cópias por célula. Os plasmídeos presentes num grande número de cópias são usados como veí- 
culos de clonagem desde que capacitem à amplificação do segmento do DNA neles clonado.

A clonagem do produto de PCR do DNA de interesse, obtido a partir dos oligonucleotídeos desenhados com sítios de restrição, em vetores de clonagem, foi feita com o objetivo de facilitar as digestões com as enzimas de restrição adequadas para a posterior subclonagem nos vetores de expressão. Foi utilizado vetor p-GEM-T easy (PROMEGA) (Figura 4.3) como sistema de transferência.

Figura 4.3: Mapa do vetor de clonagem pGEM-T Easy (PROMEGA)

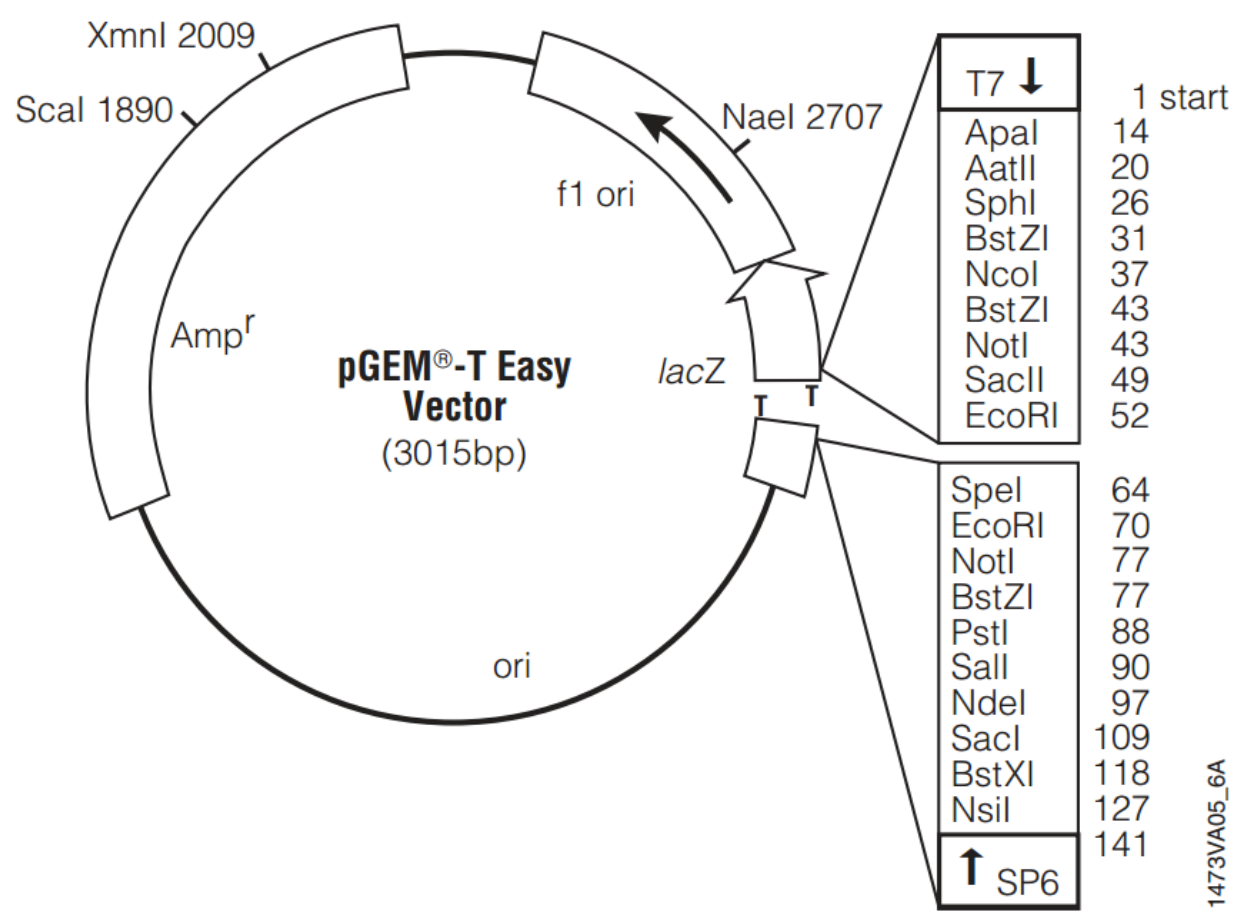

Fonte:Technical Manual pGEM $®-T$ and pGEM $®$-T Easy Vector Systems, INSTRUCTIONS FOR USE OF PRODUCTS A1360, A1380, A3600 AND A3610. Promega Corporation

Características do vetor de clonagem pGEM-T Easy:

- 3015 pares de bases

- Sítio de iniciação da transcrição T7 RNA polimerase: base 1

- Região múltipla de clonagem: bases 10-128

- Promotor SP6 RNA polimerase (-17 a +3): bases 139-158

- Sítio de iniciação da transcrição SP6 RNA polimerase: base 141

- Sítio de ligação do oligo pUC/M13 Reverse: bases 176-197 
Clonagem, expressão e purificação de álcool desidrogenase de B. subtilis para

- Códon iniciador lacZ: base 180

- Operador lac: bases 200-216

- Região codificadora $\beta$-lactamase (resistência à amplicilina): bases 13312197

- Região fago f1: 2380-2835

- Sequências do lac operon: bases 2836-2996, 166-395

- Sítio de ligação do oligo pUC/M13 "Foward": bases 2949-2972

- Promotor T7 RNA polimerase (-17 a +3): 2999-3

Vetor de expressão

\section{pET23a(+)}

Para a expressão da proteína de interesse, o DNA-alvo foi subclonado no vetor de expressão pET23a(+) (Promega) (Figura 4.4). Este vetor de expressão está sob o controle do sistema T7 no qual o DNA alvo é clonado sob o controle do promotor do gene 10 do bacteriófago T7 (Studier \& Moffatt, 1986). A expressão do DNA alvo ocorre somente na presença da RNA polimerase do vírus T7, devido à alta especificidade do promotor.

As cepas de bactérias Escherichia coli BL21(DE3) possuem, integrado ao seu genoma, o prófago do bacteriófago T7, que é lisogênico. Neste prófago, a expressão da T7 RNA polimerase está sob o controle do promotor lacUV5 do operon lac, que é mantido reprimido na presença de glicose e na ausência de seu indutor natural, a 1,6 aldolactose, um derivado da galactose (Studier \& Moffatt, 1986).

O produto do gene lac I representa o repressor que, quando ligado ao operador O (presente no prófago do T7), impede a expressão da T7 RNA polimerase, não ocorrendo a transcrição do DNA alvo. Porém, na presença de IPTG (isopropil- $\beta$-D-1-tiogalactopiranosídeo), que é um análogo do indutor natural (a 1,6-aldolactose), o repressor se desliga do operador liberando a expressão da T7 RNA polimerase do bacteriófago T7. Esta, por sua vez, atua na transcrição do DNA alvo clonado no vetor do sistema pET.

Como a T7 RNA polimerase é cinco vezes mais eficiente do que a RNA polimerase da $E$. coli e é produzida em grandes quantidades, em pouco tempo, praticamente, o único produto proteico sintetizado pela bactéria será aquele representado pelo DNA alvo clonado no vetor pET. Assim, na presença da RNA polimerase do bacteriófago T7, o DNA alvo é altamente transcrito, resultando 
em grande quantidade do produto proteico. Outra vantagem desse promotor é a sua especificidade, ou seja, a RNA polimerase da E. coli não transcreve o DNA alvo, o que permite controlar o momento exato em que ele será expresso (Studier \& Moffatt, 1986).

Figura 4.4: Mapa do vetor de expressão pET-23a(+)(Novagen)

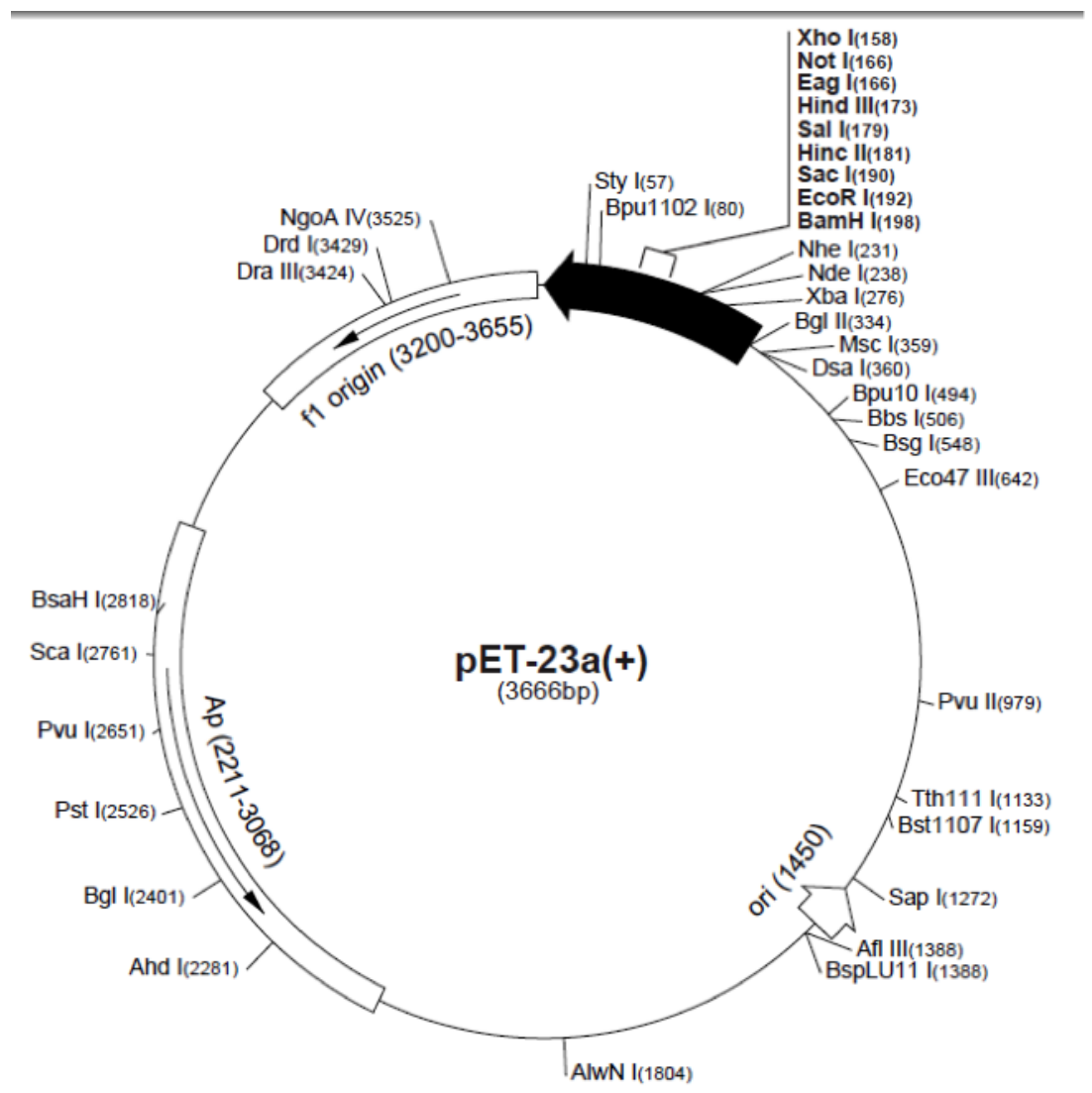

Fonte: pET System Manual - Novagen.

Características do vetor de expressão pET-23a:

- 3666 nucleotídeos

- Promotor T7: bases 303-319

- Início da transcrição T7: base 302

- Sequência codificadora da His-tag: bases 140-157

- Sequência codificadora da T7-tag: bases 207-239

- Região múltipla de clonagem (BamHI - XhoI): bases 158-203

- Terminador T7: bases 26-72

- Sequência codificadora bla: bases 2211-3068 
Clonagem, expressão e purificação de álcool desidrogenase de B. subtilis para

- Origem pBR322: base 1450

- Gene de resistência a ampicilina: bases 2134-2994

- Origem f1: bases 3200-3655

\section{pET-28a}

O sistema pET é o mais utilizado atualmente para expressão de proteínas recombinantes em Escherichia coli. O vetor pET-28a permite a expressão da proteína recombinante fusionada à 6 resíduos de histidina na extremidade amino ( $N$-terminal) ou carboxi-terminal ( $C$-terminal), o que facilita a purificação por técnicas de cromatografia de afinidade, com resinas de sefarose combinadas com o níquel. Além disso, a expressão do gene está sob o controle do promotor do fago T7, que promove a expressão gênica pela indução com IPTG em algumas linhagens de E. coli.

Os vetores do sistema de plasmídeos para Expressão com T7 RNA polimerase (pET) utilizam um promotor do fago T7 que é reconhecido pela RNA polimerase do fago (T7 RNA polimerase), mas não pela RNA polimerase da E. coli. Assim, a transcrição do DNA clonado, necessária para a síntese da proteína, só ocorre após a expressão da T7 RNA polimerase na bactéria hospedeira. Além disso, a velocidade de transcrição da T7 RNA polimerase é cinco vezes maior do que a da RNA polimerase de E. coli, conferindo, ao sistema pET altos níveis de transcrição do DNA clonado.

Os vetores pET são derivados do plasmídeo pBR322, em cujo sítio único de BamH I foi clonado o fragmento -23 a +96 do mRNA do gene 10 do fago T7. Essa sequência de nucleotídeos contém o forte promotor do gene 10 ( $\Phi 10)$, o sítio de ligação do ribossomo ou sequência de Shine-Delgarno (SD) do gene 10, os 11 primeiros aminoácidos ( $\mathrm{S} 10)$ da proteína codificada pelo gene 10 (sequência líder) e sítios de clonagem (NdeI, NheI e BamHI). Este vetor de expressão contém todos os elementos necessários para a transcrição e tradução eficiente dos DNAs clonados (Studier \& Moffatt, 1986). A Figura 4.5 mostra o mapa do vetor pET-28a. 
Figura 4.5: Mapa do vetor de expressão pET-28a (Novagen)

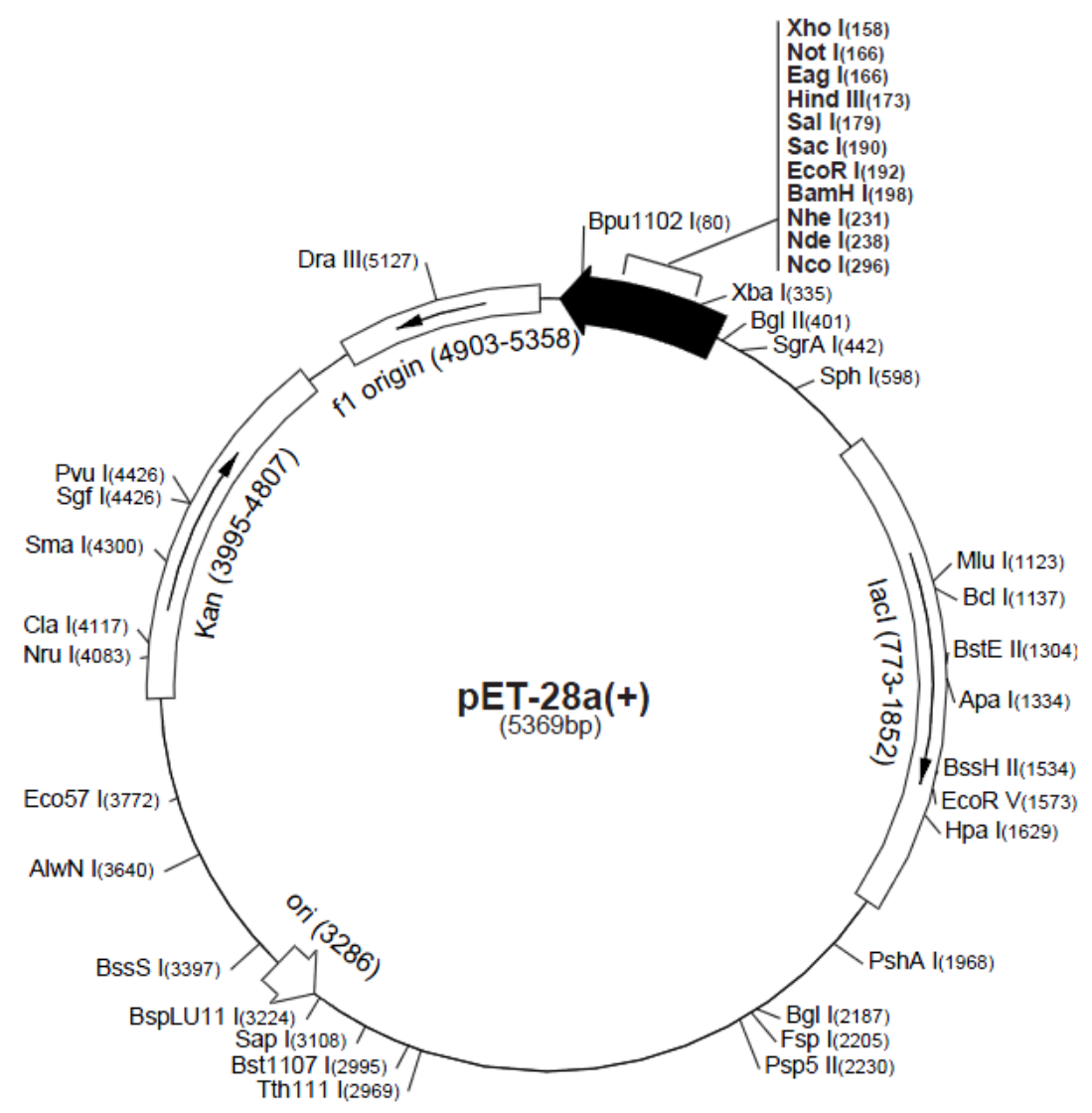

Fonte: pET System Manual - Novagen.

Características do vetor de expressão pET-28a:

- 5369 nucleotídeos

- Promotor T7: bases 370-386

- Início da transcrição T7: base 369

- Sequência codificadora da His-tag: bases 270-287

- Sequência codificadora da T7-tag: bases 207-239

- Região múltipla de clonagem (BamHI - XhoI): bases 158-203

- Sequência codificadora da His-tag: bases 140-157

- Terminador T7: bases 26-72

- Sequência codificadora lacl: bases 773-1852

- Origem pBR322: base 3286 
Clonagem, expressão e purificação de álcool desidrogenase de B. subtilis para

- Gene de resistência a canamicina: bases 3995-4807

- Origem f1: bases 4903-5358

\subsubsection{Linhagens de bactérias Escherichia coli}

A linhagem de bactérias E. coli DH5afoi utilizada para multiplicação e manutenção de vetores plasmidiais. A cepa de bactérias E. coli BL2 1(DE3)pLysS ${ }^{\circledR}$ e E. coli BL21(DE3) ${ }^{\circledR}$ (Novagen) foram utilizadas para expressar a proteína de interesse. Esta cepa possui baixos níveis de produção de proteases, que poderiam degradar a proteína alvo, e possui ainda o gene DE3 responsável pela síntese da enzima T7 RNA polimerase controlado pelo promotor lacUV5 e ativado pela adição de IPTG. Apresenta também expressão heteróloga da enzima lisozima que inibe a T7 RNA polimerase, regulando a expressão da proteína de interesse clonada no vetor do sistema pET. Esta linhagem pode ser utilizada quando a proteína alvo se apresenta tóxica para a bactéria.

\subsubsection{Meios de cultura}

O meio de cultura utilizado para o crescimento de bactérias, expressão de proteínas e para a repicagem das cepas foi o meio LB (Luria-Bertani) onde cada litro é composto de $5 \mathrm{~g}$ de extrato de levedura, $10 \mathrm{~g}$ de triptona e $10 \mathrm{~g}$ de $\mathrm{NaCl}, \mathrm{pH}$ 7,0 . O meio sólido é composto de $100 \mathrm{~mL}$ de meio LB e 1,5 g de agar bacteriológico. Os meios foram suplementados com um antibiótico (ampicilina $100 \mu \mathrm{g} / \mathrm{mL}$ e X-Gal 0,01 $\mathrm{mg} / \mathrm{mL}$ e IPTG 0,5 mM para as cepas de E. coli $\left.D H 5 \alpha \mathrm{CaCl}_{2}\right)($ ampicilina $100 \mu \mathrm{g} / \mathrm{mL}$ e cloranfenicol $25 \mu \mathrm{g} / \mathrm{mL}$ para as cepas E. coli BL21(DE3)pLysS) (ampicilina $100 \mu \mathrm{g} / \mathrm{mL}$ para as cepas E. coli BL2 1(DE3))(canamicina $50 \mu \mathrm{g} / \mathrm{mL}$ para o vetor pET-28a(+)) a fim de selecionar as bactérias que continham DNA plasmidial de interesse.

\subsubsection{Clonagem}

\section{Clonagem em pGEM-T easy (Promega)}

As clonagens no vetor pGEM-T easy foram realizadas com a utilização da T4 DNA ligase (Fermentas) e o tampão 10X T4 DNA Ligase (Fermentas). Para a reação de ligação no vetor de clonagem pGEM-T easy (Promega), deve-se realizar uma estimativa da concentração do fragmento de DNA, para se determinar a quantidade de fragmento de DNA a ser utilizada. Para tal, utilizam-se a seguinte equação: 


$$
\mathrm{x} \text { fragmento }(\mathrm{ng})=\frac{\text { tamanho do fragmento }(\mathrm{pb}) \times 100 \mathrm{ng} \text { pGEM }-\mathrm{T}}{3015 \mathrm{pb} \mathrm{pGEM}-\mathrm{T}} \times \frac{3}{1}
$$

Neste caso tem-se:

- Tamanho do fragmento $=1137 \mathrm{pb}$

- $n g$ do pGEM-T = 100 ng

Segundo a equação deve-se utilizar 113 ng do fragmento de DNA.

Reação de ligação do gene ADH com vetor pGEM-T Easy e transformação

A ligação do fragmento de interesse ao vetor foi realizada utilizando concentração adequada de DNA (100 ng), o vetor de clonagem, o tampão 10x do vetor e a enzima T4 DNA Ligase (Fermentas). A reação foi incubada a $16^{\circ} \mathrm{C}$ no banho termostático por 12 horas ("overnight") e estocada a $-20^{\circ} \mathrm{C}$. Posteriormente foi feita a transformação por meio de choque térmico em células de E. coli $\mathrm{DH} 5 \alpha \mathrm{CaCl}_{2}$ competentes, das quais foram selecionados os clones contendo o plasmídeo recombinante. A seleção foi feita utilizando $50 \mu \mathrm{g} / \mathrm{mL}$ de canamicina nas placas para identificação dos clones recombinantes (colônias brancas).

Subclonagem em pET23a(+) e pET28a(+) (Novagen)

Tanto os vetores de expressão (pET23a e pET28a) quanto o vetor de transferência (pGEM-T easy) que apresentaram o DNA alvo clonado foram submetidos à digestão exaustiva com as respectivas enzimas NdeI e EcoRI conforme o protocolo do manufaturador. Após eletroforese em agarose 0,8\% (Sambrook \& Russell, 2001), as bandas correspondentes ao fragmento de DNA de interesse e o vetor de expressão, digeridos com as enzimas adequadas, foram extraídas do gel e purificadas usando o kit QIAquick ${ }^{\circledR}$ Gel Extraction kit (QIAGEN) conforme o protocolo do fabricante.

Para a reação de ligação no vetor de expressão (pET23a(+) e pET28a(+) da Novagen, realizou-se uma estimativa da concentração do fragmento de DNA, para se determinar a quantidade de fragmento de DNA a ser utilizada. Para tal, utilizam-se a seguinte equação: Proporção inserto:vetor (3:1)

$$
\mathrm{x} \text { fragmento }(\mathrm{ng})=\frac{100 \mathrm{ng}(\text { vetor }) \mathrm{x} \text { tamanho do fragmento }(\mathrm{pb})}{3666 \mathrm{pb}(\text { vetor } \mathrm{pET} 23 \mathrm{a}(+))} \times \frac{3}{1}
$$

Neste caso tem-se: 
Clonagem, expressão e purificação de álcool desidrogenase de B. subtilis para

- Tamanho do fragmento $=1137 \mathrm{pb}$

- ng do pET23a $(+)=100 \mathrm{ng}$

Segundo a equação deve-se utilizar 93 ng do fragmento de DNA.

A reação de ligação foi realizada utilizando quantidade adequada de fragmento de DNA, o vetor de expressão (pET23a(+) ou pET28a(+)), o tampão 10x do vetor e a enzima T4 DNA Ligase (Fermentas), de acordo com o protocolo do manufaturador. A reação foi incubada a $16^{\circ} \mathrm{C}$ no banho termostático por $16 \mathrm{~h}$ e posteriormente estocada a $-20^{\circ} \mathrm{C}$.

Transformação de bactérias competentes

A transformação de bactérias pelos vetores de interesse foi realizada através do método de choque térmico. O choque térmico foi feito deixando as células 2 minutos no gelo, 2 minutos a $42^{\circ} \mathrm{C}$ e depois 3 minutos no gelo. Posteriormente acrescentou-se o meio LB líquido e deixou sob agitação a $37^{\circ} \mathrm{C}$ por 45 minutos. O produto desta transformação foi plaqueado de acordo com o item 3.11.1, para se fazer uma seleção dos clones.

Seleção dos clones transformantes

A seleção dos clones transformantes foi feita através de 4 métodos, como descritos nos itens a seguir.

- Plaqueamento em meio seletivo

Para selecionar os clones de interesse o produto de transformação foi espalhado em meio LB sólido contendo $100 \mu \mathrm{g} / \mathrm{mL}$ de ampicilina para o vetor pGEM-T easy e pET23a(+), para identificação dos clones recombinantes. As placas foram submetidas ao crescimento em temperatura constante de $37^{\circ} \mathrm{C}$ por $16 \mathrm{~h}$.

- PCR de colônia

A análise das colônias recombinantes selecionadas pelo plaqueamento em meio seletivo foi feita por PCR de colônia. Para as colônias referentes ao clone pGEM-T easy::ADH foram utilizados os oligonucleotídeos T7promoter "Forward" e SP6 "reverse", e para o clone pET23a $(+)$ e pET28a $(+)$ foram utilizados os oligonucleotídeos T7 promoter e "reverse", que se anelam aos respectivos vetores. As colônias que apresentaram a amplificação do fragmento, de tamanho compatível, foram crescidas em meio LB e os plasmídeos recombinantes foram extraídos e submetidos à análise de restrição. 
- Análise de restrição

Para a análise de restrição foram usadas as enzimas de restrição NdeI e EcoRI (New England BioLabs), cujos sítios foram inseridos nos oligonucleotídeos específicos do DNA da ADH. A clivagem foi feita utilizando o tampão 4 (10X) (1x NEBuffer 4: $50 \mathrm{mM}$ acetato de potássio, $20 \mathrm{mM}$ Tris-acetato, $10 \mathrm{mM}$ acetato de magnésio, $1 \mathrm{mM}$ DTT, $\mathrm{pH} 7,9$ a $25^{\circ} \mathrm{C}$ ) que possui $100 \%$ de eficiência para ambas as enzimas.

- Sequenciamento automático de DNA

O sequenciamento automático foi realizado pelo método de didesoxinucleotídeos, utilizando os primers do vetor em questão. Esse procedimento foi feito no equipamento 3130 Genetic Analyzer (Applied Biosystems), localizado no Laboratório do Grupo de Biofísica (IFSC) sob responsabilidade da Profa. Dra. Ana Paula Ulian de Araujo (IFSC-USP).

\subsubsection{Extração de DNA plasmidial}

A obtenção do DNA plasmidial de interesse foi realizada através do método de lise alcalina, com auxílio de kit de extração de GeneJET ${ }^{\mathrm{TM}}$ Plasmid Miniprep Kit (Fermentas), de acordo com o protocolo proposto pelo fabricante (Figura 4.6).

Figura 4.6: Etapas do protocolo de extração de DNA plasmidial

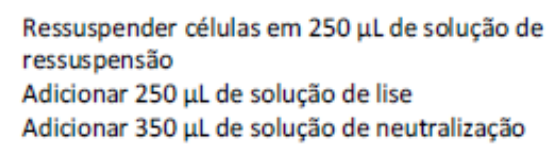

Transferir sobrenadante para a coluna GeneJET

Adicionar $500 \mu \mathrm{L}$ do tampão de lavagem

Adicionar $50 \mu \mathrm{L}$ do tampão de eluição
Ressuspensão, lise e neutralização

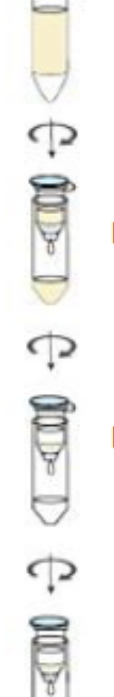

Eluição do DNA puro 
Clonagem, expressão e purificação de álcool desidrogenase de B. subtilis para 86 redução de cetonas

\subsubsection{Teste de expressão de proteínas}

O sistema de expressão utilizado para a produção das proteínas recombinantes foi o sistema pET (Studier \& Moffatt, 1986). As bactérias E. coli da linhagem BL21(DE3)pLysS ${ }^{\circledR}$ que foram previamente transformadas com o plasmídeo recombinante pET23a(+)::ADH e pET28a(+)::ADH, como descrito no item 3.10, cresceram em meio LB contendo $25 \mu \mathrm{g} / \mathrm{mL}$ de cloranfenicol e ampicilina $100 \mu \mathrm{g} / \mathrm{mL}(\mathrm{pET} 23 \mathrm{a}(+))$ ou $25 \mu \mathrm{g} / \mathrm{mL}$ cloranfenicol e canamicina $50 \mu \mathrm{g} / \mathrm{mL}$ (pET28a $(+))$, sob agitação constante a $37^{\circ} \mathrm{C}$. Este crescimento foi monitorado até que a densidade óptica a $600 \mathrm{~nm}$ atingisse 0,6 unidades de absorbância. Obtendo-se essa densidade óptica, as culturas celulares foram induzidas à expressão pela adição de IPTG na concentração final de $0,2 \mathrm{mM}$, sendo a temperatura utilizada de $30^{\circ} \mathrm{C}$, com um período de indução de 4 horas (pET23a(+)) ou IPTG na concentração final de $0,4 \mathrm{mmol} / \mathrm{L}$, temperatura de $27^{\circ} \mathrm{C}$ e período de indução de 16 horas.

O teste de indução foi avaliado por eletroforese em gel de poliacrilamida em presença de dodecil-sulfato de sódio (SDS-PAGE - seção 4.1.14). As culturas de células, após a indução, foram centrifugadas a $8000 \mathrm{rpm}$ por 30 minutos e à temperatura de $4^{\circ} \mathrm{C}$, e o sedimento bacteriano armazenado a $-80^{\circ} \mathrm{C}$ para posterior lise da proteína de interesse.

\subsubsection{SDS-PAGE}

As amostras provenientes dos testes de expressão da proteína foram submetidas, juntamente com um padrão de massa molecular (Unstained Protein Molecular Weight Marker (14000-66000 Da)(Fermentas)), à eletroforese em gel de poliacrilamida na presença de dodecil sulfato de sódio (SDS-PAGE) (Studier \& Moffatt, 1986). A eletroforese foi realizada com o aparato Mini-Protean II Dual Slab Cell (Bio-Rad), com gel de empacotamento 5\%, gel de separação $15 \%$, e voltagem de $140 \mathrm{~V}$, por aproximadamente 90 minutos. O gel foi corado por 10 minutos em etanol:ácido acético:água 5:1:15 (v:v:v) e Coomassie Brilliant Blue R (Bio-Rad) 0,25\% e descorado em ácido acético:etanol:água 3:2:35 (v:v:v).

O gel de resolução $15 \%$ foi preparado em um frasco Erlenmeyer onde adicionouse $1,1 \mathrm{~mL}$ de água deionizada, $2,5 \mathrm{~mL}$ de solução de acrilamida $30 \%$ (acrila-

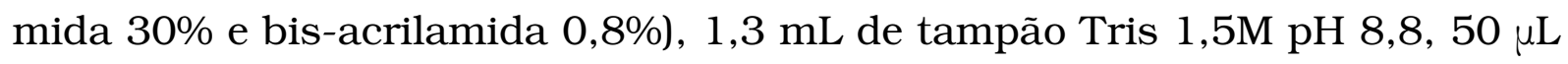
de SDS 10\%, $50 \mu \mathrm{L}$ de persulfato de amônio 10\% e $2 \mu \mathrm{L}$ de TEMED.

O gel de empacotamento 5\% foi preparado em um frasco Erlenmeyer onde adicionou-se $680 \mu \mathrm{L}$ de água deionizada, $170 \mu \mathrm{L}$ de solução de acrilamida $30 \%$ (acrilamida 30\% e bis-acrilamida 0,8\%), $130 \mu \mathrm{L}$ de tampão Tris 1,0 M pH 6,8, 
$10 \mu \mathrm{L}$ de SDS 10\%, $10 \mu \mathrm{L}$ de persulfato de amônio 10\% e $1 \mu \mathrm{L}$ de TEMED.

Foi adicionado a $40 \mu \mathrm{L}$ de amostra $20 \mu \mathrm{L}$ do tampão de amostra $2 \mathrm{X}$ constituído de $100 \mathrm{mM}$ Tris/ $\mathrm{HCl} \mathrm{pH} 6,8,4,0 \%$ de SDS, 0,2\% de azul de bromofenol, $20 \%$ de glicerol e $200 \mathrm{mM}$ de ditiotreitol.

O tampão de corrida que preenche a cuba é constituído de $25 \mathrm{mM}$ Tris, 250 mM de glicina $\mathrm{pH}$ 8,3 e 1\% de SDS em 1 L de água deionizada.

\subsubsection{Protocolo de solubilização com 2-metil-2,4-pentanodiol (MPD)}

Após a indução da E. coli transformada em $500 \mathrm{~mL}$ de meio LB as células foram centrifugadas a $8000 \mathrm{rpm}$ por $30 \mathrm{~min}$ a $4^{\circ} \mathrm{C}$. O sobrenadante foi descartado e o pellet ressuspenso em $10 \mathrm{~mL}$ do tampão I (50 mM Tris/HCl pH 8,0; $100 \mathrm{mM} \mathrm{NaCl}$ ). As células foram sonicadas 6 vezes em gelo com pulsos de 15 s e intervalos de 1 min e então centrifugadas a $7500 \mathrm{rpm}$ por $20 \mathrm{~min}$ a $4^{\circ} \mathrm{C}$.

O sobrenadante foi descartado e o pellet ressuspenso novamente em $10 \mathrm{~mL}$ do tampão I e novamente sonicado, este processo foi repetido 3 vezes. Após a última centrifugação a fração insolúvel foi ressuspensa em $10 \mathrm{~mL}$ do tampão II (50 mM Tris/HCl pH 8,0; 100 mM NaCl; 2\% SDS) e deixado sob agitação magnética por 30 min em gelo. Decorrido o tempo foram adicionados $5 \mathrm{~mL}$ de MPD, quantidade suficiente para uma concentração final de $2 \mathrm{M}$ de MPD, e a mistura permaneceu sob agitação magnética por $24 \mathrm{~h}$ a $4^{\circ} \mathrm{C}$. Após as $24 \mathrm{~h}$ a mistura foi filtrada em papel de filtro e submetida aos passos de purificação por afinidade ao níquel.

\subsubsection{Protocolo de solubilização com triton-X100}

Após a indução da $E$. coli transformada em $500 \mathrm{~mL}$ de meio LB as células foram centrifugadas a $8000 \mathrm{rpm}$ por $30 \mathrm{~min}$ a $4^{\circ} \mathrm{C}$. O sobrenadante foi descartado e o pellet ressuspenso em $10 \mathrm{~mL}$ do tampão I (0,01 M fosfato de potássio $\mathrm{pH}$ 6,0). As células foram sonicadas 6 vezes em gelo com pulsos de $15 \mathrm{~s}$ e intervalos de 1 min e então centrifugadas a $7500 \mathrm{rpm}$ por $20 \mathrm{~min}$ a $4^{\circ} \mathrm{C}$. O sobrenadante foi descartado e o pellet ressuspenso novamente em 10 $\mathrm{mL}$ do tampão II $(0,01 \mathrm{M}$ fosfato de potássio $\mathrm{pH} 6,0 ; 1,0 \%$ Triton X-100; $1 \mathrm{mM}$ 2-mercaptoetanol), a suspensão permaneceu sob agitação magnética por $3 \mathrm{~h}$ a $0^{\circ} \mathrm{C}$ e então foi centrifugada a $8000 \mathrm{rpm}$ por $1 \mathrm{~h}$ a $4^{\circ} \mathrm{C}$. O sobrenadante foi separado e submetido aos passos de purificação por afinidade ao níquel. 
Clonagem, expressão e purificação de álcool desidrogenase de B. subtilis para 88 redução de cetonas

\subsubsection{Purificação em coluna de afinidade ao níquel}

A amostra foi passada manualmente em coluna composta de $2 \mathrm{~mL}$ de resina carregada com níquel. Foi utilizado o tampão de corrida constituído de $50 \mathrm{mM}$ de Tris $/ \mathrm{HCl}$ pH 8,0, $300 \mathrm{mM} \mathrm{NaCl}$ e como tampão de eluição $50 \mathrm{mM}$ de Tris/HCl pH 8,0, 250 mM imidazol, 300 mM NaCl. Após a aplicação da amostra a coluna foi lavada com $10 \mathrm{~mL}$ do tampão de corrida, sucedida de outra lavagem com $4 \mathrm{~mL}$ de tampão de corrida com $20 \mathrm{mM}$ de imidazol. A proteína de fusão 6x His-ADH foi eluida com o tampão de eluição e a coluna lavada com $4 \mathrm{~mL}$ de tampão de corrida acrescido com $500 \mathrm{mM}$ de imidazol. Alíquotas das frações obtidas foram analisadas por SDS-PAGE.

\subsubsection{Teste de atividade enzimática da ADH}

Figura 4.7: Esquema geral da reação de oxidação de etanol a acetona no teste de atividade enzimática de $\mathrm{ADH}$ de $B$. subtilis

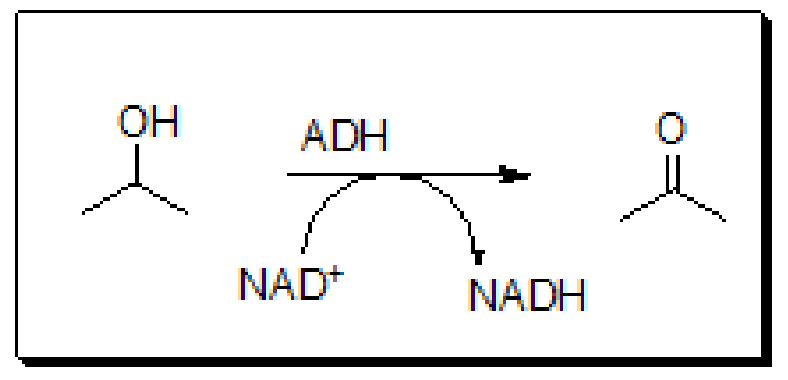

\section{Ensaio de atividade enzimática I}

Em uma cubeta de quartzo foram adicionados $3 \mathrm{~mL}$ do tampão de reação constituído de $50 \mathrm{mM}$ de $\mathrm{NaOH} /$ Glicina $\mathrm{pH}$ 9,0; 0,67 M de etanol; $8 \mathrm{mM}$ de $\mathrm{NAD}^{+}$. Foram montadas duas cubetas sendo que na cubeta denominada de branco não foi adicionada a enzima purificada, na cubeta de teste adicionouse $0,1 \mathrm{~mL}$ da proteína purificada. A absorbância em $340 \mathrm{~nm}$ foi medida a cada um minuto no intervalo entre 1 e 10 minutos.

\section{Ensaio de atividade enzimática II}

Em uma cubeta de quartzo foram adicionados $2,7 \mathrm{~mL}$ do tampão de reação constituído de $50 \mathrm{mM}$ de Tris/ $\mathrm{HCl} \mathrm{pH}$ 8,9; 2 mM de DTT; $100 \mu \mathrm{L}$ de etanol 96\%; 7,5 mM de $\mathrm{NAD}^{+}$. Foram montadas duas cubetas sendo que na cubeta denominada de branco não foi adicionada a enzima purificada, na cubeta de teste adicionou-se 0,1 mL da proteína purificada. A amostra foi incubada por 
3 minutos a $25^{\circ} \mathrm{C}$ e a leitura da absorbância em $340 \mathrm{~nm}$ foi medida a cada um minuto no intervalo entre 3 e $10 \mathrm{~min}$.

\subsubsection{Emprego da ADH de B. subtilis clonada na reação de redução de cetonas}

\section{Ensaio 1}

Em um frasco Erlenmeyer de $250 \mathrm{~mL}$ contendo $100 \mathrm{~mL}$ de meio LB, células de BL21(DE3) transformadas com o clone pET28::ADH e canamicina permaneceu sob agitação orbital a $37^{\circ} \mathrm{C}$ até atingir $\mathrm{DO} 600 \mathrm{~nm}=0,4$. Foi adicionado $0,4 \mathrm{mM}$ de IPTG e permaneceu sob agitação orbital por $16 \mathrm{~h}$ a $27^{\circ} \mathrm{C}$. Após o tempo de indução foram adicionados $25 \mathrm{mg}$ de 4-iodo-acetofenona e a mantendo-se sob agitação orbital a $27^{\circ} \mathrm{C}$ por mais $24 \mathrm{~h}$. Ao final do tempo reacional uma alíquota da reação após filtração em algodão foi analisada por cromatografia a gás.

\section{Ensaio $\|$}

Em um frasco Erlenmeyer de $250 \mathrm{~mL}$ contendo $100 \mathrm{~mL}$ de meio LB, células de BL21(DE3) transformadas com o clone pET28::ADH e canamicina permaneceu sob agitação orbital a $37^{\circ} \mathrm{C}$ até atingir DO $600 \mathrm{~nm}=0,4$. Foi adicionado 0,4 mM de IPTG e $25 \mathrm{mg}$ de 4-iodo-acetofenona mantendo-se sob agitação orbital a $27^{\circ} \mathrm{C}$ por $24 \mathrm{~h}$. Ao final do tempo reacional uma alíquota após filtração em algodão foi analisada por cromatografia a gás.

\section{Ensaio III}

Em um frasco Erlenmeyer de $50 \mathrm{~mL}$ contendo $10 \mathrm{~mL}$ da enzima lisada em tampão de lise (25 mM Tris/ $\mathrm{HCl}$ pH 8,0; $50 \mathrm{mM} \mathrm{NaCl;} 10 \mathrm{mM}$ de $\mathrm{ZnSO}_{5}$ ), 25 $\mathrm{mg}$ de 4-iodo-acetofenona e $7 \mathrm{mg}$ de NADH manteve-se sob agitação orbital a $37{ }^{\circ} \mathrm{C}$ por mais 7 dias. Uma alíquota de cada dia de reação após filtração em algodão foi analisada por cromatografia a gás.

\subsection{Resultados e Discussão}

Esta etapa do trabalho foi realizada no laboratório de Biologia Molecular e Bioquímica sob supervisão da Profa Dra Fernanda Canduri (IQSC). 


\subsubsection{Fluxograma dos experimentos}

Para facilitar a sequência dos procedimentos realizados neste trabalho, segue na Figura 4.8 um fluxograma sumarizando as etapas envolvidas na clonagem e expressão da $\mathrm{ADH}$ de $B$. subtilis isolada da alga marinha $B$. tenella.

Figura 4.8: Fluxograma das etapas envolvidas no desenvolvimento deste trabalho frente a clonagem, expressão e atividade enzimática de ADH de B. subtilis.

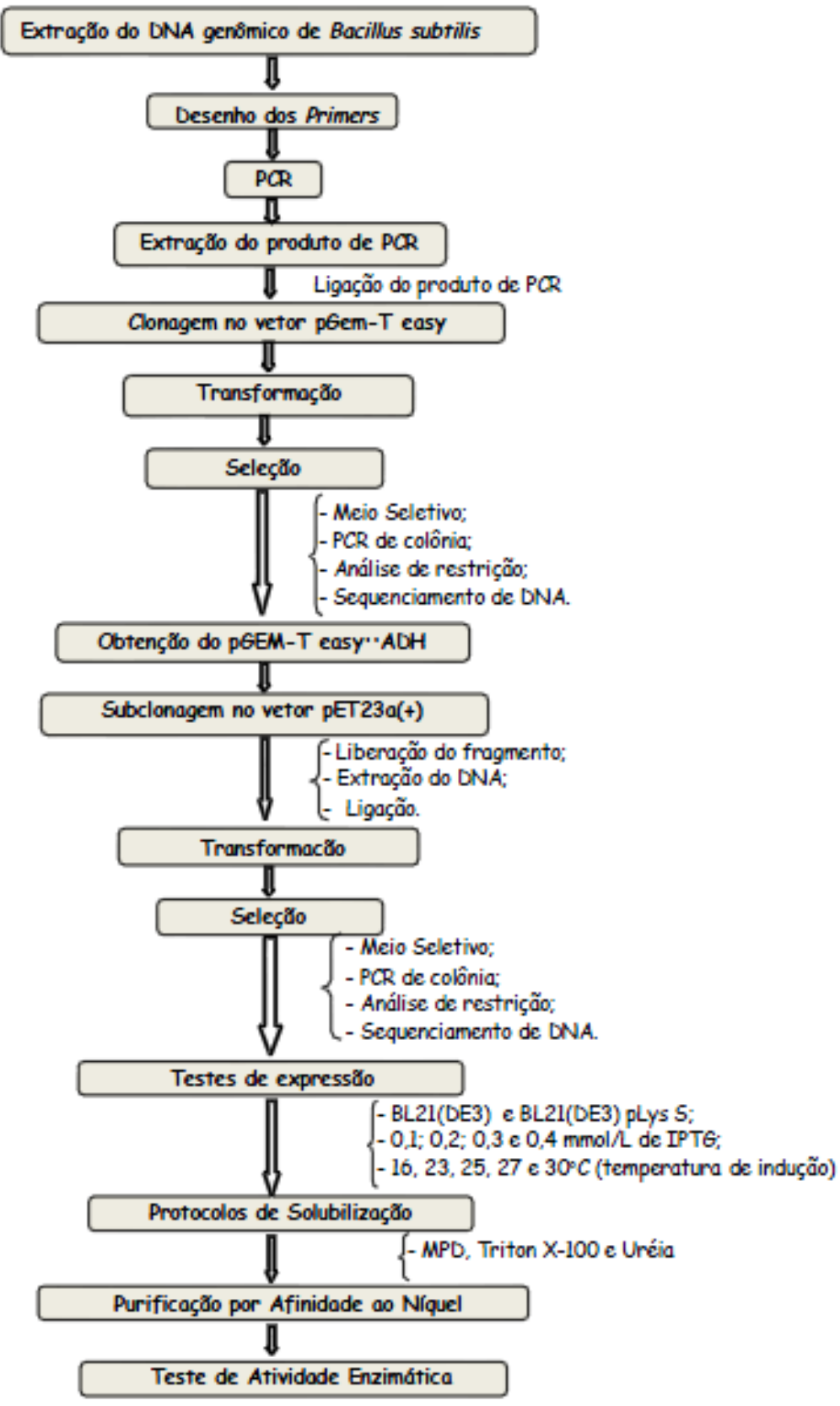




\subsubsection{Banco de dados e bioinformática}

O DNA molde referente a álcool desidrogenase (ADH) foi identificado através de pesquisa no banco de dados genômico para Bacillus subtilis utilizando a busca da sequência de aminoácidos da proteína $\mathrm{ADH}$, previamente identificada no banco de dados GenBank ${ }^{1}$ do NCBI (National Center of Biotechnology Information). A busca foi realizada através da ferramenta de bioinformática tBLASTn (Basic Local Alignment Search Tool) que utiliza sequência de aminoácidos para identificar sequências de nucleotídeos. Portanto, o primeiro passo foi conhecer a sequência de nucleotídeos.

\subsubsection{Protocolo de extração do DNA genômico bacteriano}

O DNA genômico bacteriano foi extraído segundo protocolo fornecido para o Kit AxyPrep DNA Genômico Bacteriano Miniprep da AXYGEN (Figura 4.9) que pode extrair até $20 \mathrm{mg}$ de DNA genômico de $1 \times 10^{9}$ células bacterianas. A amostra foi quantificada através da razão entre as leituras de absorbância em 260 e $280 \mathrm{~nm}$ fornecendo a concentração de $2,5 \mathrm{mg}$ de DNA genômico extraído da cultura de células de $B$. subtilis em $100 \mathrm{~mL}$ de meio LB.

Figura 4.9: Kit AxyPrep DNA Genômico Bacteriano Miniprep (AXYGEN)

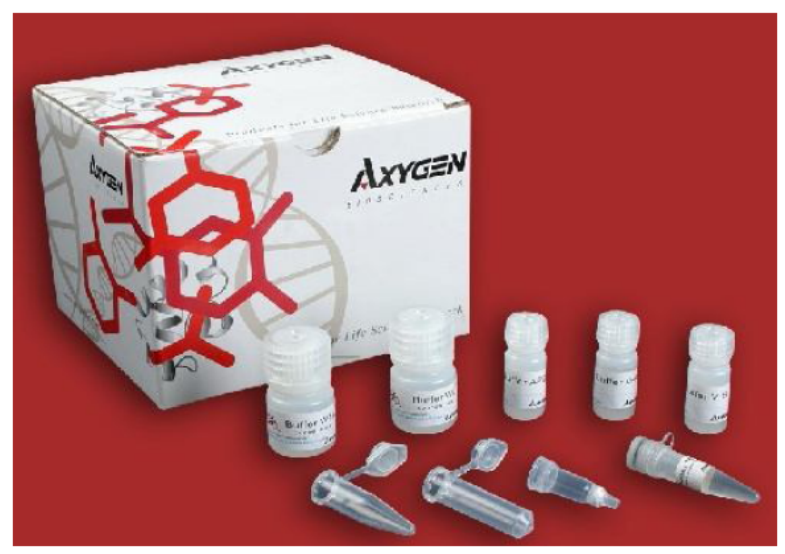

Fonte: http://www.axygen.com.br/produto.php?codigo=APMNBTGDNA50\&lp=0

\subsubsection{Construção dos oligonucleotídeos iniciadores para PCR (pri- mers)}

Existem recomendações específicas para a construção de primers, como as relatadas por Lisby (1999); University (2012); HENEGARIU (1997). São elas:

\footnotetext{
${ }^{1}$ http://www.ncbi.nlm.nih.gov/genbank/GenbankSearch.html
} 
Clonagem, expressão e purificação de álcool desidrogenase de $B$. subtilis para

1. estabelecer o tamanho dos primers entre 18 e 24 bases para minimizar o risco de anelamentos inespecíficos;

2. assegurar relação entre bases purinas e pirimidinas entre 40 e $60 \%$ para a maximização da especificidade da reação, evitando uma concentração de bases G/C inferior a 50\%, de forma a não prejudicar o cálculo da temperatura de anelamento;

3. procurar sequência do primer com maior concentração de bases $G / C$ na extremidade 5' e menor concentração (um C ou um G) na porção 3';

4. evitar trincas de bases repetidas;

5. evitar complementariedade inter e intramolecular, principalmente na extremidade 3' para impedir formação de estruturas secundárias como a ocorrência de dímeros;

6. construir um arranjo de bases que permita uma temperatura de anelamento entre $52^{\circ} \mathrm{C}$ e $65^{\circ} \mathrm{C}$, sendo crucial que as temperaturas de fusão dos dois primers sejam próximas.

Os primers foram construídos a partir das sequências de DNA da ADH identificada no banco de dados Genbank (código GI 1934622) inserindo-se sítios para a enzima de restrição NdeI no iniciador 5' na região do códon de iniciação do DNA alvo, e EcoRI no iniciador 3' na região do códon de terminação do DNA alvo (Figura 4.10).

Figura 4.10: Oligonucleotídeos iniciadores (primers), constituídos a partir das sequências de DNA da $\mathrm{ADH}$

$$
\begin{gathered}
\text { F - ADH - 5' - AGA CAT ATG AAG GCA GTA ACG TAT CAA GGC - 3' } \\
\text { R - ADH - 5' - AGA GAA TTC TTA AGG CTT TAA CAC AAC TTT GAT AC - 3' }
\end{gathered}
$$

Observando o início e o fim da sequência do DNA da $\mathrm{ADH}$ de $B$. subtilis na figura 4.11 é possível reconhecer que no primer "Foward" são identificadas as 24 bases iniciais e que no primer "Reverse" são identificadas as 26 bases finais complementares as da sequência aqui apresentada, esta informação se destaca em vermelho nas Figuras 4.11 e 4.12.

Os primers funcionam como os iniciadores da reação de polimerização, se anelando especificamente às suas sequências complementares na fita molde, delimitando o fragmento de DNA que se deseja amplificar (Farah, 2000). Dando continuidade na construção dos primers foi necessária a inserção dos códons de iniciação (ATG) e terminação (ATT) que são responsáveis por indicar onde a 
Figura 4.11: Início e fim da sequência de bases do DNA da $\mathrm{ADH}$ de $B$. subtilis retirado do GenBank

atgaaggcag taacgtatca aggcattaaa aatgttgttg tcaaagatgt ccccgatcca
aagattgaaa aatccgatga catgattatc aaagtcacca gtacagccat ttgcggatca

aaaattgatc cgggagatgt tgtcagccat gtcctgccgc ttagtgaagc caagcatggc tatgacattt ttgattcaaa aatggatgat tgtatcaaag ttgtgttaaa gccttaa

enzima Taq DNA polimerase deve iniciar e finalizar a replicação do DNA de interesse. Na Figura 4.12 identifica-se na cor verde os códons ATG e a sequência complementar do códon de terminação TAA.

Figura 4.12: Identificação dos elementos utilizados na construção dos primers.

$$
\begin{aligned}
& \text { F - ADH - 5' - AGA CAT ATG AAG GCA GTA ACG TAT CAA GGC - 3' } \\
& \text { F - ADH - 5'- AGA CAT ATG AAG GCA GTA ACG TAT CAA GGC - 3' } \\
& \text { F - ADH - 5' - AGA CAT ATG AAG GCA GTA ACG TAT CAA GGC - 3' } \\
& \text { R - ADH - 5'- AGA GAA TTC TTA AGG CTT TAA CAC AAC TTT GAT AC - 3' } \\
& \text { R - ADH - 5' - AGA GAA TTC TTA AGG CTT TAA CAC AAC TTT GAT AC - 3' } \\
& \text { R - ADH - 5'- AGA GAA TTC TTA AGG CTT TAA CAC AAC TTT GAT AC - 3' }
\end{aligned}
$$

Em vermelho destaca-se a sequência de bases referentes ao fragmento de DNA da $\mathrm{ADH}$. Em verde são destacados os códons de iniciação da transcrição no primer "Foward" e o de terminação no primer "Reverse". Em rosa os sítios de restrição para NdeI no "Foward" e EcoRI no "Reverse".

Para finalizar a construção do primer foi necessária a inserção da sequência que indica onde as enzimas de restrição devem atuar e realizar a clivagem do DNA para obtenção de uma extremidade coesiva que será futuramente o ponto de ligação entre o inserto (fragmento de DNA de interesse) e o plasmídeo (moléculas circulares de DNA). No primer construído para a $\mathrm{ADH}$ foram utilizadas as sequências para NdeI (Foward) e EcoRI (Reverse) que são destacadas em rosa na Figura 4.12. Após o desenho dos primers a sequência desejada foi sintetizada e certificada pela empresa Integrates DNA Technologies (IDT ${ }^{\circledR}$ ).

\subsubsection{Reação em cadeia da polimerase (PCR)}

A reação de PCR é uma técnica que utiliza a enzima DNA polimerase responsável pela síntese de DNA, para amplificar in vitro, qualquer segmento de DNA utilizado como molde através de ciclos. Cada ciclo é composto de 3 etapas sendo que a primeira delas é a desnaturação que promove a partir de alta temperatura $\left(95^{\circ} \mathrm{C}\right.$ por $\left.30 \mathrm{~s}\right)$ a separação da dupla cadeia de DNA. Na segunda 
etapa, o anelamento, a temperatura é reduzida entre 50 a $60^{\circ} \mathrm{C}$ onde o primer se anela com a fita molde de DNA. Por fim na etapa de extensão a temperatura é elevada a $72^{\circ} \mathrm{C}$ para que a enzima polimerase possa atuar sintetizando a nova molécula de DNA (Figura 4.13). Normalmente são realizados de 25 a 40 ciclos para cada reação na qual a taxa de replicação é exponencial (van Pelt-Verkuil et al., 2008).

Figura 4.13: Etapas de replicação do DNA através de PCR

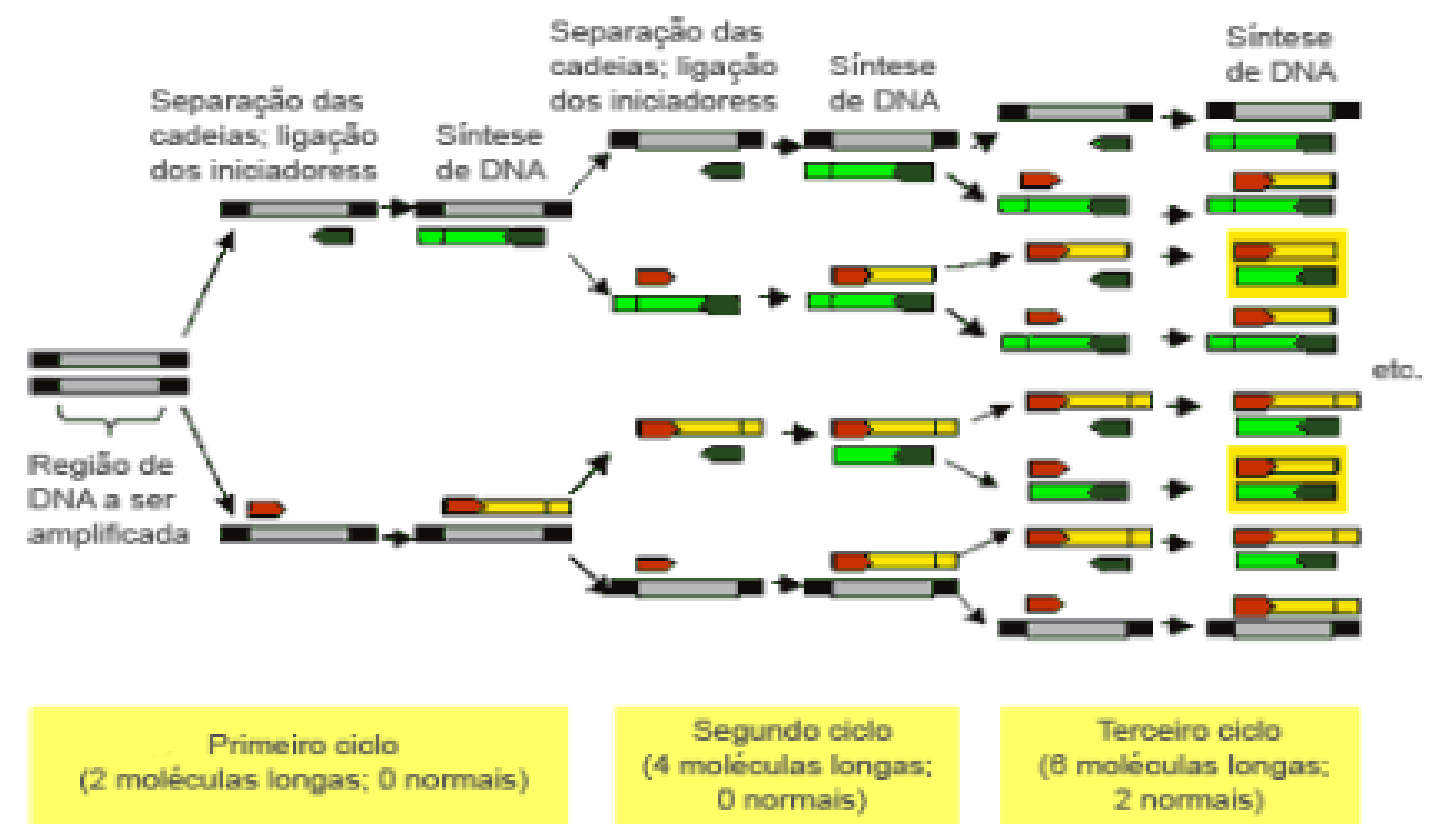

Fonte: e-escola - INSTITUTO SUPERIOR TÉCNICO- http://eescola.ist.utl.pt/topico.asp?hid=339 ACESSADO DIA 08/11/2012

$\mathrm{O}$ fragmento de DNA referente à $\mathrm{ADH}$ foi amplificado por meio da reação em cadeia da polimerase ("polymerase chain reaction" - PCR), utilizando a enzima de alta fidelidade High-Fidelity PCR Enzyme Mix (Fermentas) e os oligonucleotídeos específicos sintetizados. Após a varredura de temperaturas foi estabelecida que a temperatura de $60,5^{\circ} \mathrm{C}$ era a ideal com 36 ciclos de replicação. O produto de PCR foi analisado através de eletroforese em gel de agarose 0,8\% (Figura 4.14A) onde foi possivel identificar a banda em torno de 1137 pares de base conforme indica o marcador molecular presente no gel. Posteriormente, o fragmento de DNA foi purificado usando o kit GIAquick ${ }^{\circledR}$ Gel Extraction kit (QIAGEN)(Figura 4.14B) que fornece até $10 \mu \mathrm{g}$ de DNA entre 70 pb e $10 \mathrm{~kb}$, onde foi obtido o fragmento de DNA na concentração de $5 \mu \mathrm{g}$, o qual foi utilizado para realizar a subclonagem no vetor de propagação pGEMT easy (PROMEGA). 
Figura 4.14: Eletroforese em gel de agarose $0,8 \%$ e PCR QIAquick Gel Extraction Kit (QIAGEN)
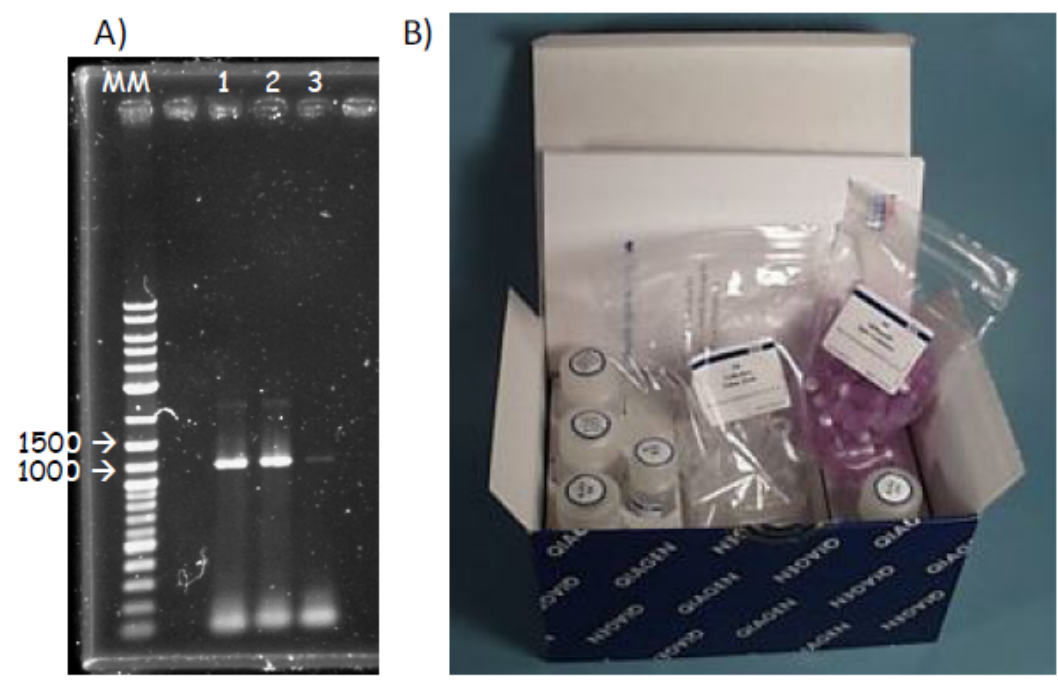

A) Eletroforese em gel de agarose 0,8\% das alíquotas obtidas na reação de PCR com os primers específicos referentes ao DNA da ADH. As bandas MM (marcador molecular) referem-se ao marcador High DNA Mass Ladder (10000 - 100 pb) (Invitrogen). As bandas de 1-3 do gel referem-se à amplificação do DNA de 1137 pb (ADH). B) Kit para purificação de produto de PCR QIAquick Gel Extraction Kit (QIAGEN) - Fonte: http://www.thermoscientificbio.com/nucleic-acidelectrophoresis/generuler-1-kb-dna-ladder-ready-to-use-250-to-10000-bp

\subsubsection{Determinação da concentração de DNA}

A determinação da concentração de DNA deu-se através da eletroforese em gel de agarose onde foi feita através da comparação entre a intensidade da banda de DNA marcada com brometo de etídio e a intensidade de bandas padrão de DNA (GeneRulerTM 1Kb DNA Ladder - Fermentas)(Figura 4.15) e também com o uso do equipamento Thermo Scientific NanoDropTM 1000 Spectrophotometer, localizado no laboratório do Grupo de Biofísica (IFSCUSP) sob responsabilidade da Profa Dra Ana Paula Ulian de Araújo. Para o clone pGEM::ADH foi obtida a concentração de 425,7 ng/ $\mu \mathrm{L}$. Já para os clones de expressão pET23::ADH a concentração foi de $48,8 \mathrm{ng} / \mu \mathrm{L}$ e para o clone pET28::ADH a concentração de $83,1 \mathrm{ng} / \mu \mathrm{L}$.

Na Figura 4.15 tem-se o marcador molecular padrão de DNA onde é possível reconhecer ao lado de cada banda primeiramente o tamanho da proteína por ela representada em pares de base indo de $10000 \mathrm{pb}$ a $250 \mathrm{pb}$ e a segunda informação se refere a concentração da proteína que pode ser analisada visualmente pela intensidade da banda indo de $70 \mu \mathrm{g}$ a $25 \mu \mathrm{g}$. Estas informações foram utilizadas para determinação de concentração aproximada através da 
eletroforese em gel de agarose.

Figura 4.15: Padrão do marcador molecular com a comparação da intensidade das bandas relacionada com a concentração das mesmas

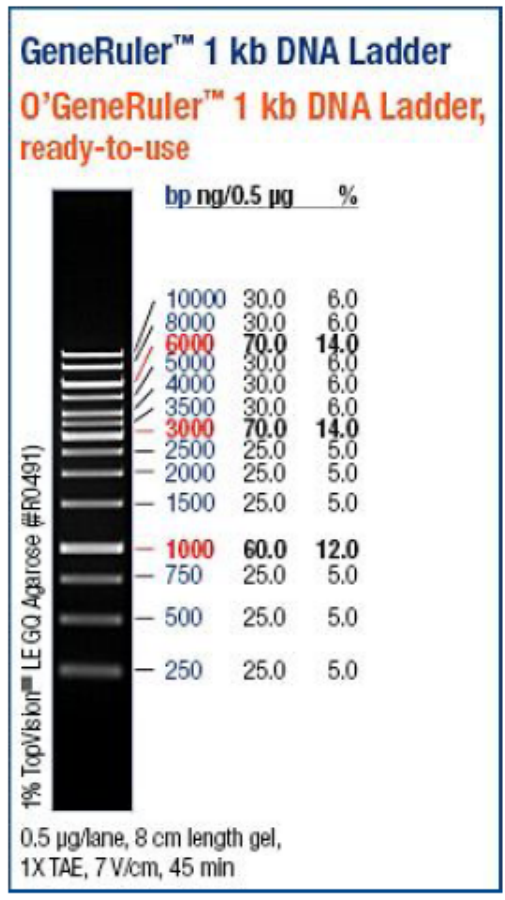

http://nihsc.od.nih.gov/productdetails.aspx?\&pid=513\&faID=160

\subsubsection{Clonagem}

A técnica central da metodologia do DNA recombinante é a clonagem molecular, a qual consiste no isolamento e propagação de moléculas de DNA idênticas. Em geral, a clonagem molecular compreende dois estágios importantes: i) a ligação de um fragmento de DNA de interesse, denominado inserto, a uma outra molécula de DNA, denominada vetor, a fim de formar uma terceira molécula, o DNA recombinante; ii) a molécula do DNA recombinante é introduzida numa célula hospedeira compativel, num processo chamado de transformação. A célula hospedeira que adquiriu a molécula do DNA recombinante é denominada de transformante ou célula transformada. Um único transformante, em condições ideais, sofre muitos ciclos de divisão celular, produzindo uma colônia que contém milhares de cópias do DNA recombinante (Figura 4.16). 
Figura 4.16: Clonagem molecular e seus estágios de ligação do fragmento de DNA de interesse ao plasmídeo e inserção do DNA recombinante na célula hospedeira (transformação)

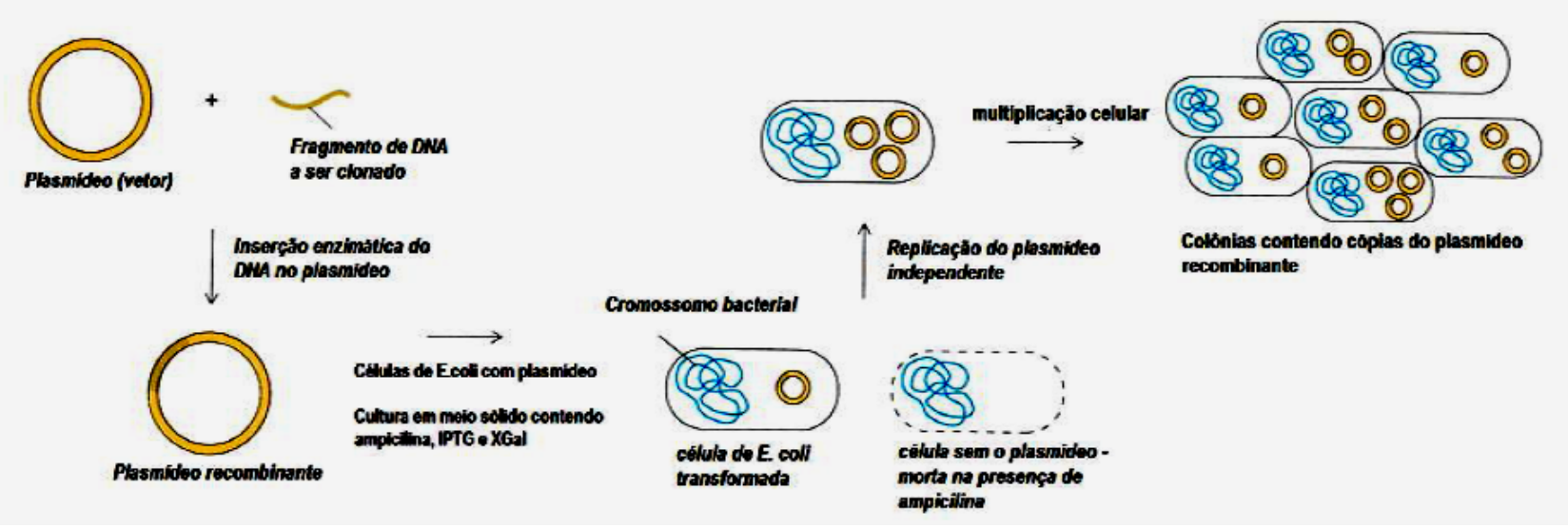

Fonte: http://tainano.com/chin/Molecular\%20Biology\%20Glossary.htm

\subsubsection{Clonagem do DNA da ADH de B. subtilis e ligação no ve- tor de clonagem $\mathrm{PGEM}-\mathrm{T}$ - Easy}

A clonagem do produto de PCR do DNA de interesse, obtido a partir dos oligonucleotídeos desenhados com sítios de restrição, em vetores de clonagem, foi feita com o objetivo de facilitar as digestões com as enzimas de restrição adequadas para a posterior subclonagem nos vetores de expressão. Foi utilizado vetor p-GEM-T easy (PROMEGA) como sistema de transferência.

A reação de ligação e a transformação em células competentes DH5 $\alpha$ (Figura 4.17A) foram realizadas segundo os protocolo do item 4.1.11 e a efetividade da transformação confirmada pelo aparecimento de colônias brancas no plaqueamento seletivo.

Para confirmação da clonagem foi realizado um PCR das colônias selecionadas utilizando os primers do inserto (Figura 4.17B) e o PCR foi analisado por eletroforese em gel de agarose 0,8\% que apresentou bandas com tamanhos entre 1000 e 1500 pares de base o que confirma a presença do fragmento de DNA desejado com tamanho de $1137 \mathrm{pb}$.

As colônias selecionadas que continham o DNA recombinante foram incubadas em $5 \mathrm{~mL}$ de meio líquido LB suplementado com ampicilina e permaneceram “overnight" sob agitação orbital a $37^{\circ} \mathrm{C}$ para obtenção de uma quantidade de células suficiente para extração do DNA plasmidial ligado ao vetor de clonagem. Após este período o DNA plasmidial foi purificado utilizando GeneJET ${ }^{\mathrm{TM}}$ Plasmid Miniprep Kit (Fermentas)(Figura 4.18) e armazenado a $-20^{\circ} \mathrm{C}$. 
Figura 4.17: Plaqueamento seletivo e PCR de colônia
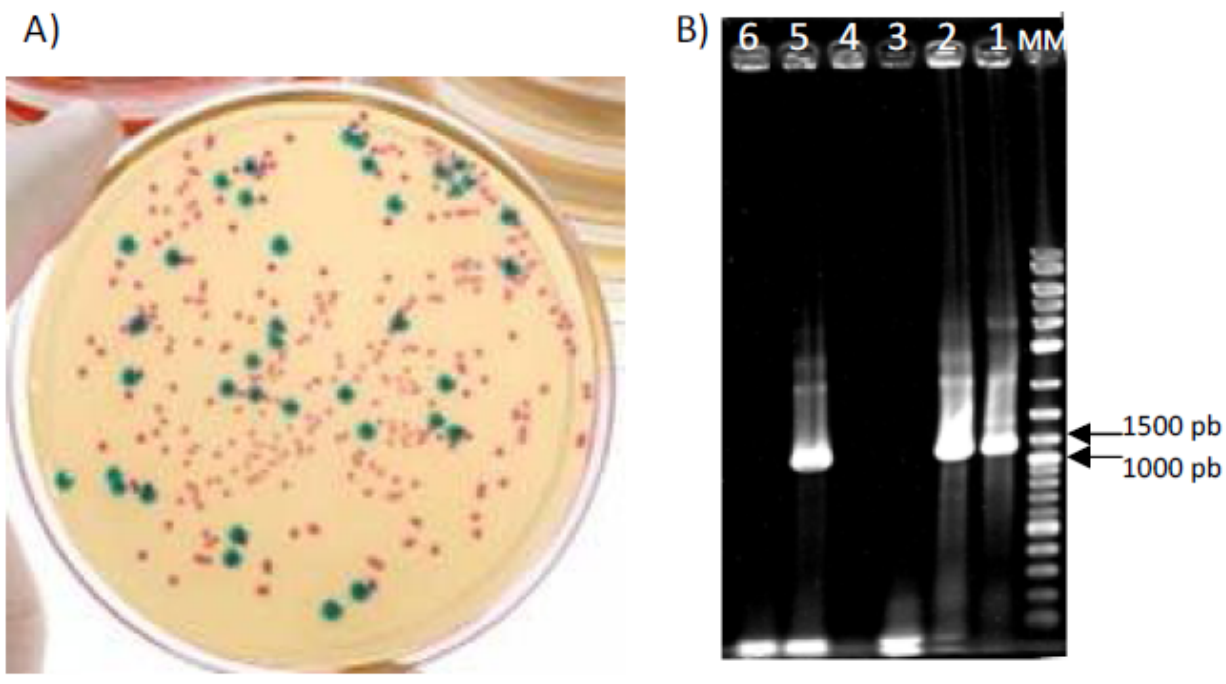

A) Meio seletivo para clonagem em vetor de propagação pGEM-T-Easy, colônias brancas indicam a presença do inserto. B) Eletroforese em gel de agarose 0,8\% das alíquotas obtidas na reação do PCR de colônia para o inserto pGEM-TEASy::ADH em células de DH5 $\alpha$ com os primers específicos referentes ao DNA da ADH. As bandas MM referem-se ao marcador High DNA Mass Ladder (10000 - 100 pb) (Invitrogen). As bandas de 1-6 do gel referem-se à amplificação do DNA de $1137 \mathrm{pb}(\mathrm{ADH})$

Figura 4.18: Kit de purificação do DNA plasmidial - GeneJET ${ }^{\mathrm{TM}}$ Plasmid Miniprep Kit (Fermentas)

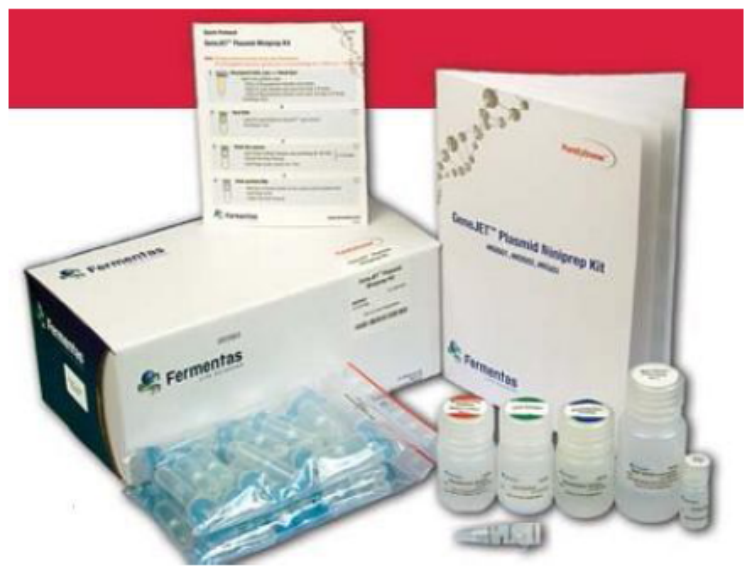

Fonte: http://www.biocenter.hu/termekek.php?termekid=17119\&fokategoria=1\&kategor 


\subsubsection{Clivagem do DNA plasmidial com enzimas de restrição}

O DNA plasmidial (pGEM-T-Easy::ADH) foi submetido a clivagem com as enzimas de restrição NdeI e EcoRI a $37{ }^{\circ} \mathrm{C}$ por $4 \mathrm{~h}$. A liberação do inserto foi confirmada por eletroforese em gel de agarose 0,8\% (Figura4.19) onde foi observada a banda referente a liberação do inserto no tamanho de 1137 pb e então purificado usando o kit QIAquick ${ }^{\circledR}$ Gel Extraction kit (QIAGEN). A quantificação foi realizada com o uso do equipamento NanoDrop ${ }^{\mathrm{TM}} 1000$ resultando uma concentração de $372 \mathrm{ng} / \mathrm{mL}$ que se mostra uma quantidade suficiente para posteriores utilizações.

Figura 4.19: Clivagem do DNA plasmidial (pGEM-T-Easy::ADH) com enzimas de restrição NdeI e EcoRI

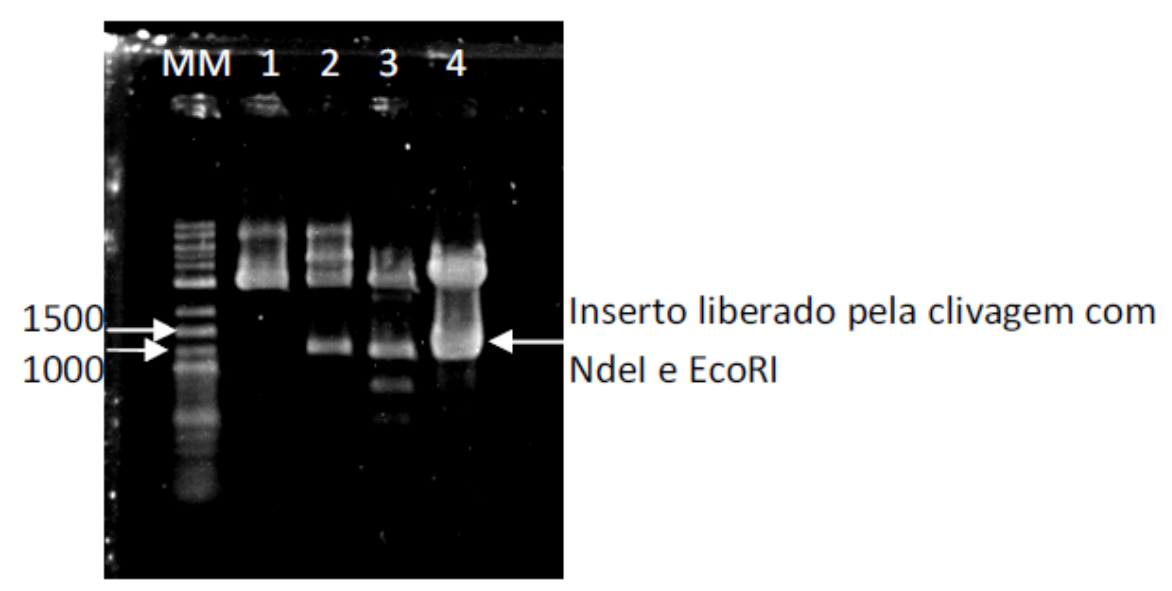

As bandas MM referem-se ao marcador High DNA Mass Ladder (10000 - 100 pb) (Invitrogen). 1-DNA puro 2- DNA clivado somente com NdeI 3- DNA clivado somente com EcoRI 4- DNA clivado pelas duas enzimas NdeI e EcoRI onde foi possível observar a liberação do inserto do DNA de 1137 pb (ADH).

\subsubsection{Sequenciamento automático de DNA}

O sequenciamento automático foi realizado pelo método de didesoxinucleotídeos, utilizando os primers do vetor em questão. A Figura 4.20 mostra apenas um trecho do sequenciamento a fim de observar a qualidade dos dados identificada pela presença de picos finos e bem definidos.

Com a realização do sequenciamento observou-se a existência de três mutações no DNA da ADH desejada, sendo que duas mutações foram silenciosas. A mutação ocorrida no resíduo 277 foi conservativa - da trinca GAA (Glutamato) para GAT (Aspartato) - a qual não influencia na estrutura da proteína, pois envolve a troca de aminoácidos pertencentes ao mesmo grupo ácido (aminoácidos carregados negativamente) (Figura 4.21). 
Figura 4.20: Trecho da análise do sequenciamento automático do recombinante pGEM-T easy::ADH, mostrando a boa qualidade dos dados obtidos evidenciada devido à presença de picos finos

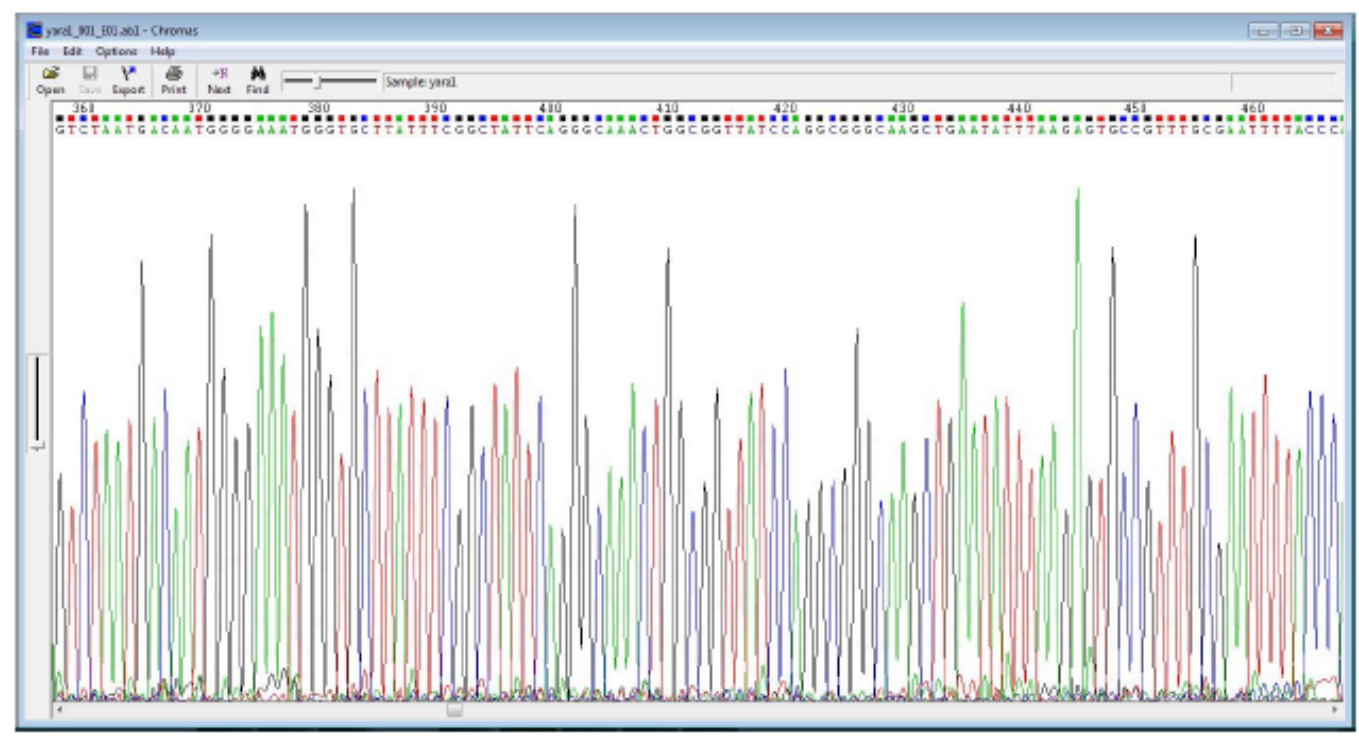

Figura 4.21: Comparação do DNA sequenciado (b) com o fornecido pelo banco de dados GenBank (a) mostrando a mutação conservativa no resíduo 278.
a) $\mathrm{ADH}$
250
260
270
280
290
300
b) Elseq
: : : : : : : : : : : : : : : : : : : : : : : : : : : : : : : : : : :
TCTTTTGTAAAAACCAGCTG
290
300
310
320
330
340

Em Biologia, mutações são mudanças na sequência dos nucleotídeos do material genético de um organismo. Mutações podem ser causadas por erros de cópia do material durante a divisão celular, por exposição a radiação ultravioleta ou ionizante, mutagênicos químicos, ou vírus. A célula pode também causar mutações deliberadamente durante processos conhecidos como hipermutação (Nussbaum et al., 2007).

A sequência de um gene pode ser alterada de diversas maneiras. Mutações genéticas têm diferentes efeitos dependendo de onde ocorrem e podem alterar a função de proteínas essenciais. Dentre os vários tipos de mutações a que foi observada neste trabalho durante a análise do sequenciamento do DNA da $\mathrm{ADH}$ foi a mutação pontual que é geralmente causada por substâncias mutagênicas ou erros na replicação do DNA, onde há a troca de um único nucleotídeo por outro. A mais comum, conhecida por transição, ocorre quando há a troca de uma purina por outra purina $(\mathrm{A} \leftrightarrow \mathrm{G})$ ou uma pirimidina por outra pirimidina ( $\mathrm{C} \leftrightarrow \mathrm{T}$ ) (Figura 4.22). Um tipo de mutação pontual menos comum é a transversão, em que há a troca de uma purina por uma pirimidina, 
ou vice-versa $(\mathrm{C} / \mathrm{T} \leftrightarrow \mathrm{A} / \mathrm{G})($ Speicher et al., 2010).

Figura 4.22: Bases nitrogenadas purinas (adenina e timina) e pirimidinas (citosina e timina).<smiles>Nc1ncnc2[nH]cnc12</smiles><smiles>Nc1nc2[nH]cnc2c(=O)[nH]1</smiles>

Guanina

Pirimidinas<smiles>Nc1cc[nH]c(=O)n1</smiles>

Citosina<smiles>Cc1c[nH]c(=O)[nH]c1=O</smiles>

Duas variedades das mutações pontuais são as silenciosas e as conservativas, que foram as observadas neste caso. De acordo com o código genético, um certo aminoácido pode ser determinado por mais de um códon; algumas mutações, no entanto, não alteram a sequência de aminoácidos produzida pelo gene modificado e sua função permanece a mesma, sendo assim chamada de mutação silenciosa. Por exemplo: o aminoácido prolina pode ser determinado pelos códons CCA, CCC, CCG e CCU. Portanto, uma mutação na terceira base desses códons não provocaria mudança na sequência de aminoácidos da cadeia polipeptídica (Regateiro, 2003).

Nas mutações conservativas o gene modificado altera a sequência de aminoácidos no peptídeo, no entanto, o aminoácido é substituído por outro que tem natureza similar (Batmanian et al., 2009). Como na mutação ocorrida no DNA da $\mathrm{ADH}$ onde uma adenina carregada negativamente (com grupo ácido) foi substituído por uma timina com mesma carga não afetando a estrutura da proteína.

\subsubsection{Vetores de expressão}

Os vetores de expressão controlada são muito importantes em Engenharia Genética, uma vez que dão resposta à necessidade de super produzir, de uma forma controlada, o produto de expressão de um gene (uma proteína recombinada).

Os fragmentos de DNA de 1137 pb que codificam para a proteína ADH de 
Clonagem, expressão e purificação de álcool desidrogenase de B. subtilis para 102 redução de cetonas

B. subtilis foram subclonados nos vetores pET28a(+) e pET23a(+). Esta nova construção denominada pET28::ADH foi escolhida para expressar a proteína de interesse fusionada com uma cauda de seis histidinas. Novamente, os plasmídeos recombinantes recém construídos foram inseridos por choque térmico em bactérias de E. coli DH5 $\alpha$ competentes, plaqueadas em placas semelhantes ao processo anterior, porém somente com adição de canamicina (um antibiótico que torna o meio seletivo) para o clone pET28::ADH, o novo antibiótico de seleção, e com adição de ampicilina (antibiótico) para o clone pET23::ADH. Após serem incubadas para o crescimento a seleção das colônias foi realizada unicamente pela análise de restrição, já que os vetores pET28a e pET23a não apresentam genes que as tornem de coloração diferenciada.

Após o período de crescimento celular, algumas colônias foram selecionadas pela sua aparência aleatoriamente dentre as muitas colônias presentes na placa de Petri, e inoculadas seguindo o mesmo processo descrito anteriormente no item 4.2.9. Após o crescimento individual destas células, seus DNAs foram extraídos, quantificados e uma alíquota destes DNAs foi clivada por enzimas de restrição (EcoRI e NdeI). Estas amostras de DNA também apresentaram concentrações variando de 100 a $150 \mathrm{ng} \mu \mathrm{L}^{-1}$. A Figura 4.23 ilustra o novo perfil de restrição dos clones selecionados onde observa-se no poço 1 o DNA puro (pET23::ADH), no poço 2 o DNA clivado apenas com NdeI, no poço 3 o DNA clivado apenas po EcoRI e no poço 4 a clivagem efetiva pelas duas enzimas mostrada pela presença do inserto no tamanho de $1137 \mathrm{pb}$. Tal resultado confirmou a ligação do inserto ao vetor de expressão.

A presença dos insertos em todos os clones selecionados confirmou o sucesso das etapas de subclonagem e transformação das células de E. coli . Uma vez confirmada a presença do inserto, os clones foram utilizados para transformar as células competentes de expressão de E. coli BL21(DE3) e E. coli BL2 1(DE3)pLysS. A seleção de novos clones contendo as ADH's subclonadas nos vetores de expressão foi realizada após o plaqueamento das células em meio adequado a cada vetor, e estes clones foram empregados na produção da proteína expressa de forma heteróloga. 
Figura 4.23: Teste de clivagem do pET-23a para liberação do inserto $(\mathrm{ADH})$

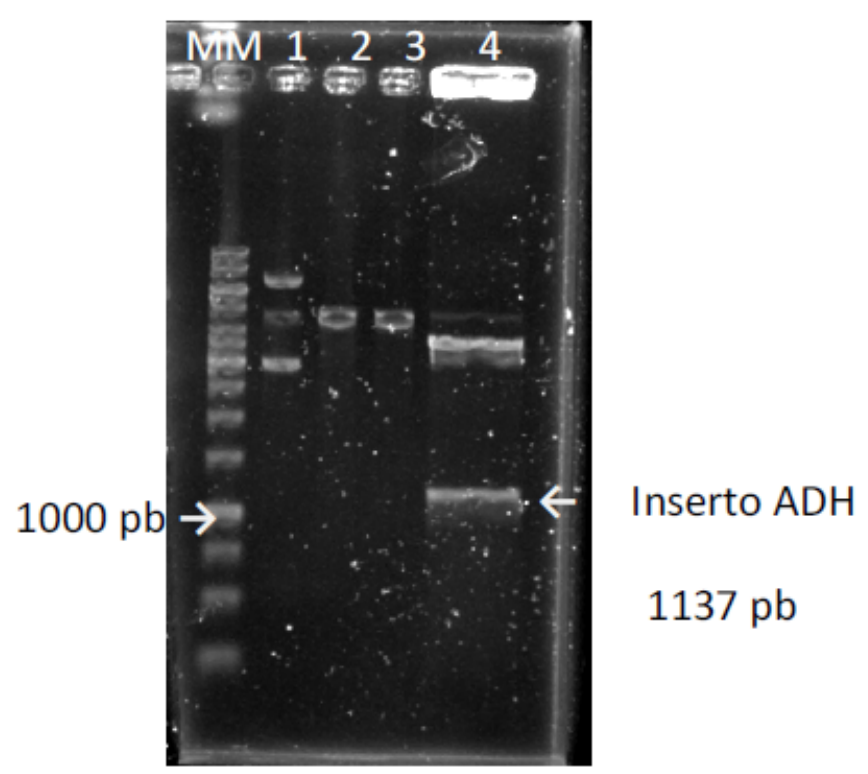

As bandas MM referem-se ao marcador High DNA Mass Ladder (10000 - 100 pb) (Invitrogen). 1-DNA puro 2- DNA clivado somente com NdeI 3- DNA clivado somente com EcoRI 4- DNA clivado pelas duas enzimas NdeI e EcoRI onde é possivel ver a liberação do inserto do DNA de 1137 pb (ADH)

\subsubsection{Expressão heteróloga da proteína ADH a partir dos veto- res de expressão}

A produção da proteína recombinante foi realizada inicialmente por meio da indução da expressão por $0,4 \mathrm{mM}$ de IPTG a $37^{\circ} \mathrm{C}$. Visando otimizar a expressão proteica, foram realizadas induções em diversas temperaturas para a quantificação da expressão de modo a obter quantidades adequadas da proteína recombinante a serem empregadas nas etapas de caracterização.

Passado o período de indução, as células bacterianas resultantes foram recuperadas por centrifugação e lisadas na presença de tampão de lise tris-HCl $\mathrm{pH} 8,0$. Os extratos proteicos foram avaliados quanto a sua solubilidade em SDS-PAGE. Na Tabela 4.1 pode-se observar as condições testadas na expressão da $\mathrm{ADH}$.

A Figura 4.24 mostra os géis de SDS-PAGE (15\%) das principais condições testadas, obtidos após submeter as amostras a condições desnaturantes. Em destaque na cor amarela pode-se observar as bandas de proteína solúvel e em vermelho tem-se que em alguns casos já ocorre naturalmente a presença de uma banda na altura de $42 \mathrm{kD}$. Esta banda em $42 \mathrm{kD}$ confirmou a expressão da $\mathrm{ADH}$ pela célula. 
Tabela 4.1: Condições testadas na expressão de ADH de B. subtilis.

\begin{tabular}{|c|c|c|c|c|}
\hline Clone & Célula & $\begin{array}{c}\text { Temperatura } \\
\left({ }^{\circ} \mathrm{C}\right)\end{array}$ & Tempo (h) & Solubilidade \\
\hline pET28::ADH & BL21(DE3) & 37 & 4 & Insolúvel \\
\hline pET28::ADH & BL21(DE3) & 30 & 4 & Insolúvel \\
\hline pET28::ADH & BL21(DE3) & 27 & 16 & Moderadamente solúvel \\
\hline pET28::ADH & BL21(DE3) & 25 & 16 & Pouco solúvel \\
\hline pET28::ADH & BL21(DE3) & 23 & 16 & Pouco solúvel \\
\hline pET28::ADH & BL21(DE3) & 16 & 16 & Insolúvel \\
\hline pET28::ADH & BL21(DE3)pLysS & 37 & 4 & Insolúvel \\
\hline pET28::ADH & BL21(DE3)pLysS & 30 & 4 & Insolúvel \\
\hline pET28::ADH & BL21(DE3)pLysS & 27 & 16 & Insolúvel \\
\hline pET28::ADH & BL21(DE3)pLysS & 25 & 16 & Pouco solúvel \\
\hline pET28::ADH & BL21(DE3)pLysS & 23 & 16 & Insolúvel \\
\hline pET28::ADH & BL21(DE3)pLysS & 16 & 16 & Insolúvel \\
\hline pET23::ADH & BL21(DE3) & 37 & 4 & Insolúvel \\
\hline pET23::ADH & BL21(DE3) & 30 & 4 & Insolúvel \\
\hline pET23::ADH & BL21(DE3) & 27 & 16 & Pouco solúvel \\
\hline pET23::ADH & BL21(DE3) & 25 & 16 & Pouco solúvel \\
\hline pET23::ADH & BL21(DE3) & 23 & 16 & Insolúvel \\
\hline pET23::ADH & BL21(DE3) & 16 & 16 & Insolúvel \\
\hline pET23::ADH & BL21(DE3)pLysS & 37 & 4 & Insolúvel \\
\hline pET23::ADH & BL21(DE3)pLysS & 30 & 4 & Insolúvel \\
\hline pET23::ADH & BL21(DE3)pLysS & 27 & 16 & Pouco solúvel \\
\hline PET23::ADH & BL21(DE3)pLysS & 25 & 16 & Moderadamente solúvel \\
\hline pET23::ADH & BL21(DE3)pLysS & 23 & 16 & Moderadamente solúvel \\
\hline pET23::ADH & BL21(DE3)pLysS & 16 & 16 & Insolúvel \\
\hline
\end{tabular}


Figura 4.24: Géis de poliacrilamida 15\% frente à expressão da $\mathrm{ADH}$ de B. subtilis
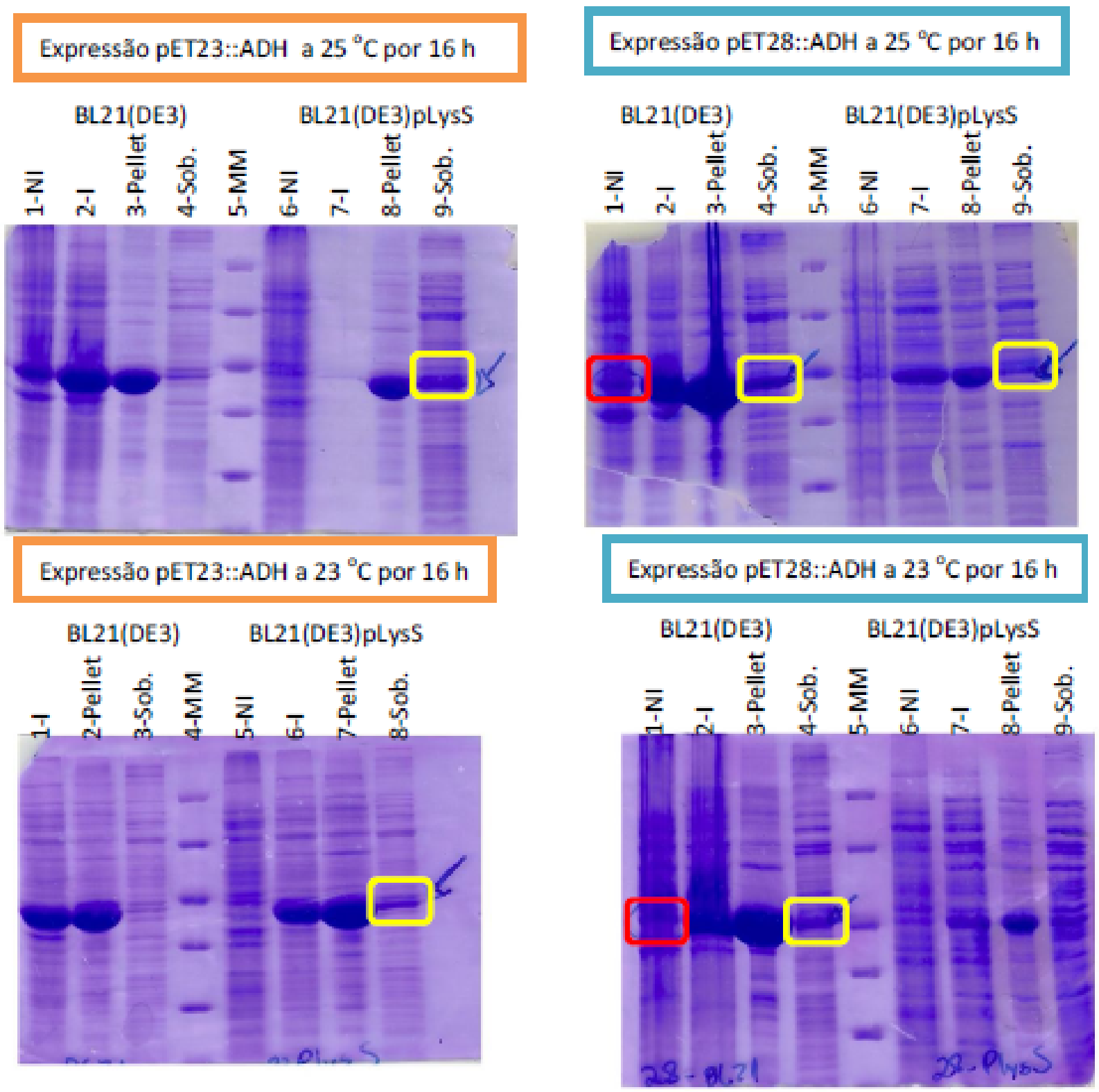

Géis de poliacrilamida 15\% mostrando no destaque em amarelo a banda referente à $\mathrm{ADH}(42 \mathrm{kDa})$. Em vermelho tem-se que em algumas situações a banda de $42 \mathrm{kD}$ já está presente na amostra não induzida. MM) marcador molecular Thermo Scientific Unstained Protein Molecular Weight Marker (14,4 kDa a 116 kDa) NI) amostra não induzida; I) amostra induzida; Pellet) amostra do pellet; Sob) amostra do sobrenadante 
Clonagem, expressão e purificação de álcool desidrogenase de B. subtilis para 106 redução de cetonas

\subsection{Solubilização da ADH com 2-metil-2,4-pentanodiol (MPD)}

O re-enovelamento de proteínas a partir do estado desnaturado é de considerável interesse teórico e prático. Uma situação comum é o re-enovelamento de proteínas a partir de corpos de inclusão insolúveis produzidos durante a expressão bacteriana recombinante. A fim de recuperar a proteína em sua forma funcional, corpos de inclusão são normalmente solubilizados com concentrações elevadas de um agente caotrópico tal como uréia ou cloridrato de guanidina. As tentativas de re-enovelamento de proteínas envolvem a redução da concentração de desnaturante, por exemplo por diluição (Swietnicki, 2006). Embora esta técnica seja comumente utilizada o processo muitas vezes pode falhar devido à elevada propensão das proteínas agregarem mediante a remoção do desnaturante.

Álcoois, tais como etanol, 2-propanol e 2-metil-2,4-pentanodiol (MPD) são osmólitos que têm efeitos sobre a estrutura e solubilidade da proteína e estes álcoois levam a hidratação preferencial dos peptídeos que constituem a estrutura principal da proteína e espera-se, portanto, que estabilizem estados nativos. Contudo, a sua natureza não polar conduz a interações hidrofóbicas favoráveis com cadeias laterais, resultando em um efeito desestabilizador líquido (Bolen, 2004). Apesar das suas propriedades moderadamente desestabilizantes, o MPD é geralmente compatível com os estados enovelados e é amplamente usado como um agente precipitante em experimentos de cristalização de proteínas (Anand et al., 2002). Também o MPD pode apresentar um efeito protetor da desnaturação causada pelo dodecil sulfato de sódio (SDS) em proteína e em muitos casos pode re-enovelar proteínas a partir do estado SDS-desnaturado (Michaux et al., 2008).

Levando em consideração que a quantidade de proteína $\mathrm{ADH}$ presente na porção solúvel foi insuficiente para que se pudessem seguir os passos de purificação e demais testes necessários para elucidação estrutural, foi necessário utilizar protocolos de solubilização para obtenção de maior concentração de proteína. Após a expressão da proteína cujo recombinante pET28::ADH foi transformado em células de BL21(DE3), as mesmas foram centrifugadas e ressuspensas em tampão de lise específico passando por uma etapa de sonicação e posterior centrifugação.

O processo de sonicação foi repetido 3 vezes para efetuar a limpeza da porção insolúvel que foi ressuspensa em tampão contendo $2 \%$ de SDS e permaneceu sob agitação a $0^{\circ} \mathrm{C}$ por 30 min e então adicionado $2 \mathrm{M}$ de MPD. A mistura permaneceu sob agitação por $24 \mathrm{~h}$, filtrada e então foi submetida à purificação por afinidade ao níquel em coluna cromatográfica manual. Como é 
mostrado na Figura 4.25 o processo de solubilização foi eficiente obtendo uma grande quantidade de proteína solúvel e pura após a etapa cromatográfica.

Figura 4.25: SDS-PAGE da purificação da ADH expressa de $B$. subtilis solubilizada com MPD

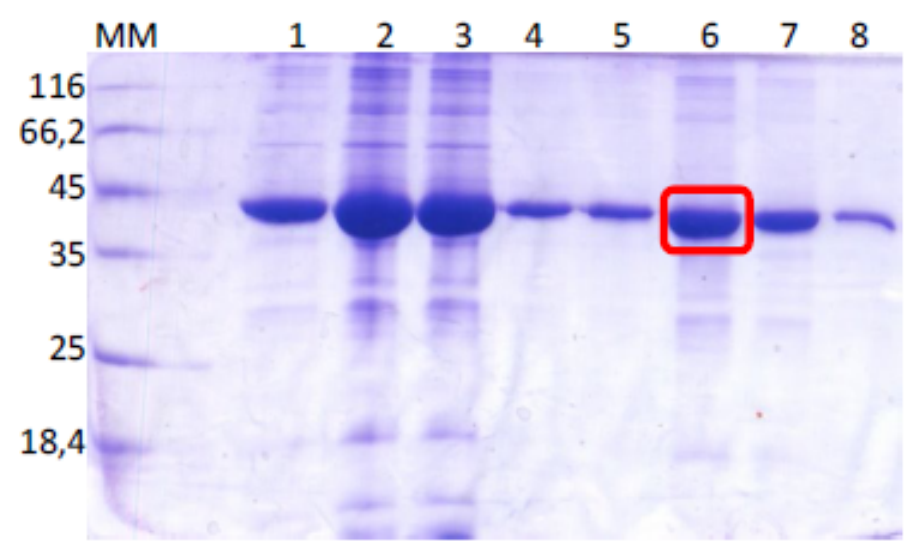

Gel de poliacrilamida 15\% realizado após purificação por afinidade ao níquel com amostra solubilizada através do protocolo com MPD. MM) Marcador de massa molecular (14,4 kDa a $116 \mathrm{kDa})$; 1) amostra do pellet induzido; 2) proteína solubilizada com MPD antes da purificação; 3) proteína solubilizada após a passagem pela coluna de afinidade; 4) lavagem da coluna com tampão; 5) lavagem da coluna com $20 \mathrm{mM}$ de Imidazol; 6) Eluição da proteína com 250 mM de Imidazol; 7) limpeza da coluna com 500 mM de Imidazol; 8) limpeza da coluna com $1 \mathrm{M}$ de Imidazol.

\subsection{Solubilização da ADH com triton-X100}

O Triton-X100 é um detergente com carga líquida neutra diferentemente do SDS que é um surfactante aniônico com carga líquida negativa, que serve para desnaturar proteínas e facilitar a solubilização das mesmas. Com intuito de se obter uma maior quantidade de proteína solúvel e em sua conformação nativa foi testada a solubilização com Triton-X100.

Após a expressão da proteína pET28::ADH em BL21(DE3) as células foram centrifugadas e ressuspensas em tampão fosfato de potássio e então submetidas a uma etapa de sonicação e posterior centrifugação. O pellet foi ressuspenso em tampão fosfato de potássio e adicionados $1 \%$ de Triton-X100 e $1 \mathrm{mM}$ de 2-mercaptoetanol. A suspensão permaneceu sob agitação por $3 \mathrm{~h} \mathrm{a} 0^{\circ} \mathrm{C}$ e centrifugada a $68.000 \mathrm{~g}$ por $1 \mathrm{~h}$. O sobrenadante foi purificado em etapa de cromatografia de afinidade ao níquel em coluna manual.

Na Figura 4.26 tem-se o gel de poliacrilamida 15\% da proteína após purificação onde foi possível observar que a ligação da proteína na coluna de afinidade não se deu de forma efetiva como foi quando solubilizada com MPD, 
Clonagem, expressão e purificação de álcool desidrogenase de B. subtilis para 108 redução de cetonas

o que mostrou que este método não é eficiente para a solubilização da $\mathrm{ADH}$ de B. subtilis.

Figura 4.26: SDS-PAGE da purificação da ADH solubilizada com Triton $\mathrm{X}-100$

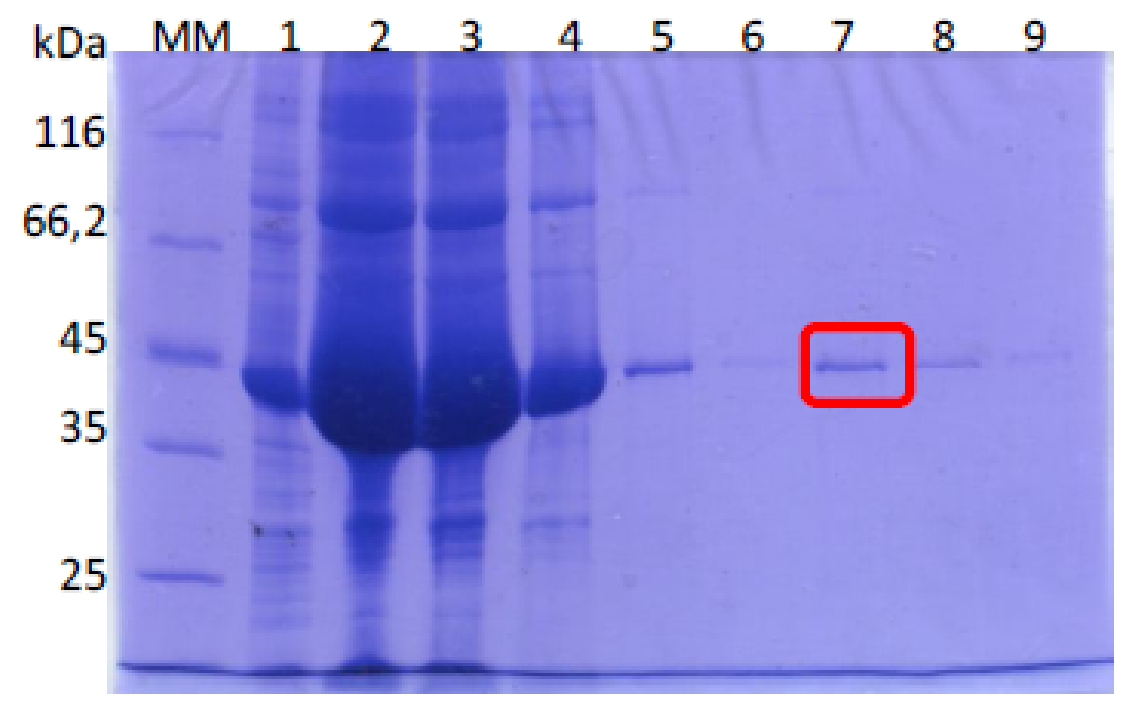

Gel de poliacrilamida 15\% realizado após purificação por afinidade ao níquel com amostra solubilizada através do protocolo com Triton-X100. MM) Marcador de massa molecular (14,4 kDa a $116 \mathrm{kDa})$; 1) amostra do pellet induzido; 2) proteína solubilizada com Triton-X100 antes da purificação; 3) proteína solubilizada após a passagem pela coluna de afinidade; 4) lavagem da coluna com tampão; 5) segunda lavagem da coluna com tampão; 6) lavagem da coluna com 20 mM de imidazol; 7) Eluição da proteína com 250 mM de imidazol; 8) limpeza da coluna com 500 mM de imidazol; 9) limpeza da coluna com 1 M de imidazol

\subsection{Testes de atividade enzimática da ADH}

Foram realizados dois testes de atividade enzimática para a ADH expressada frente ao etanol como substrato, porém não foi obtidas leituras de absorbância em $340 \mathrm{~nm}$, isto se deu devido a baixa concentração da enzima purificada que não foi suficiente para oxidar o etanol a aldeído.

\subsubsection{Emprego da $A D H$ de $B$. subtilis clonada na reação de redução de cetonas}

Visando melhores conversões e excessos enantioméricos na reação de redução de cetonas catalisada pela $\mathrm{ADH}$ de $B$. subtilis, foram realizados 3 ensaios com a enzima clonada. Primeiramente foram utilizadas células de BL21(DE3) transformadas com o clone pET28::ADH e induzidas com IPTG por $16 \mathrm{~h}$ onde 
se adicionou a 4-iodo-acetofenona e manteve sob agitação orbital por 24 horas. Após análise por cromatografia a gás foi observada uma baixa conversão (2\%). O mesmo ocorreu quando utilizadas células de BL21(DE3) transformadas com o clone pET28::ADH onde a adição do IPTG e da 4-iodo-acetofenona se deu ao mesmo tempo e mantendo-se sob agitação orbital por 24 horas e apresentando uma conversão de $2 \%$. Nestes caso, seria interessante otimizar as condições reacionais para fornecer melhores rendimentos como por exemplo a quantidade de substrato, temperatura e $\mathrm{pH}$.

Por fim foi testada a reação em meio de tampão de lise Tris/ $\mathrm{HCl}$ contendo a enzima após lise das células induzidas e o cofator NADH. Foram retiradas alíquotas a cada $24 \mathrm{~h}$ por 7 dias e analisadas por cromatografia a gás resultando em nenhuma conversão do material de partida no produto desejado.

Tais resultados podem ter ocorrido devido ao fato da enzima $\mathrm{ADH}$ estar sendo expressa em corpos de inclusão (na forma insolúvel) pela célula de expressão, podendo-se concluir que a baixa conversão obtida em alguns casos ocorreu pela atividade da $\mathrm{ADH}$ da própria célula de BL21(DE3) e não pela ADH de $B$. subtilis clonada. 


\subsection{Conclusões}

A enzima álcool desidrogenase de $B$. subtilis foi clonada com sucesso apresentando 3 mutações em seu DNA, sendo que 2 mutações são silenciosas e uma é conservativa o que não afeta a estrutura conformacional da proteína.

A expressão foi realizada de forma efetiva apresentando maior porção solúvel da proteína quando utilizado o clone pET28::ADH em células de BL2 1(DE3) e com a adição de $0,4 \mathrm{mM}$ de IPTG, a $27^{\circ} \mathrm{C}$ por 16 horas.

Como a quantidade de proteína solúvel foi insuficiente, protocolos de solubilização foram testados, onde a solubilização com MPD resultou em boa quantidade de proteína solúvel. Devido ao fato dos testes de atividade não gerarem respostas satisfatórias não foi possivel afirmar que o re-enovelamento da proteína tenha se dado de forma eficaz derivando na proteína em sua forma ativa. 


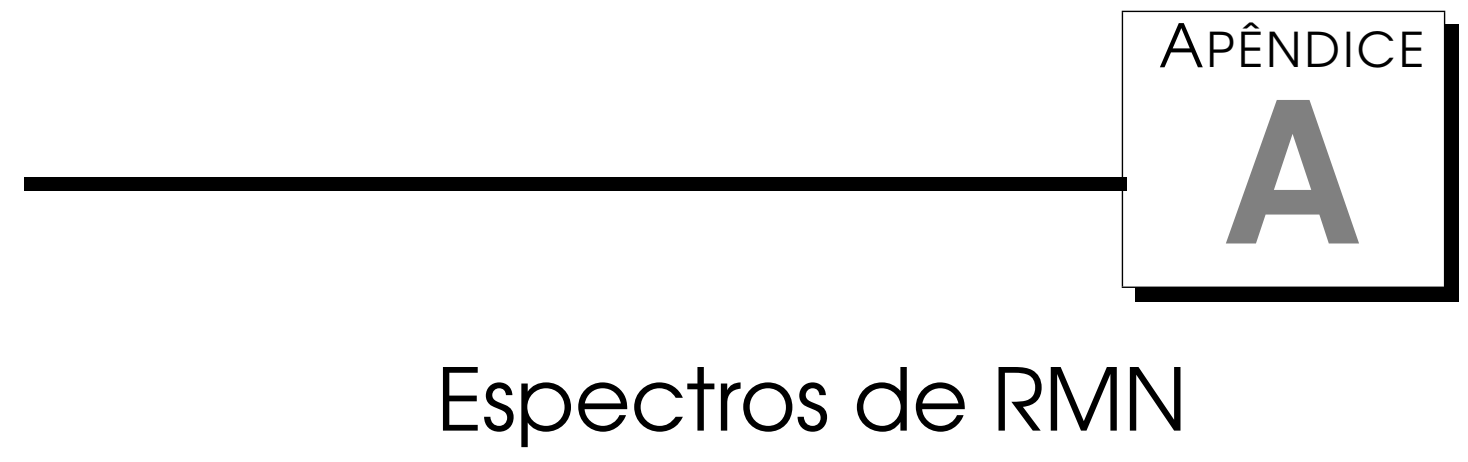

A. 1 Amidas

Figura A.1: Espectro de $\mathrm{RMN}$ de ${ }^{1} \mathrm{H}$ da $N$-(1-metil-hexil)acetamida (4) em $\mathrm{CDCl}_{3}$.

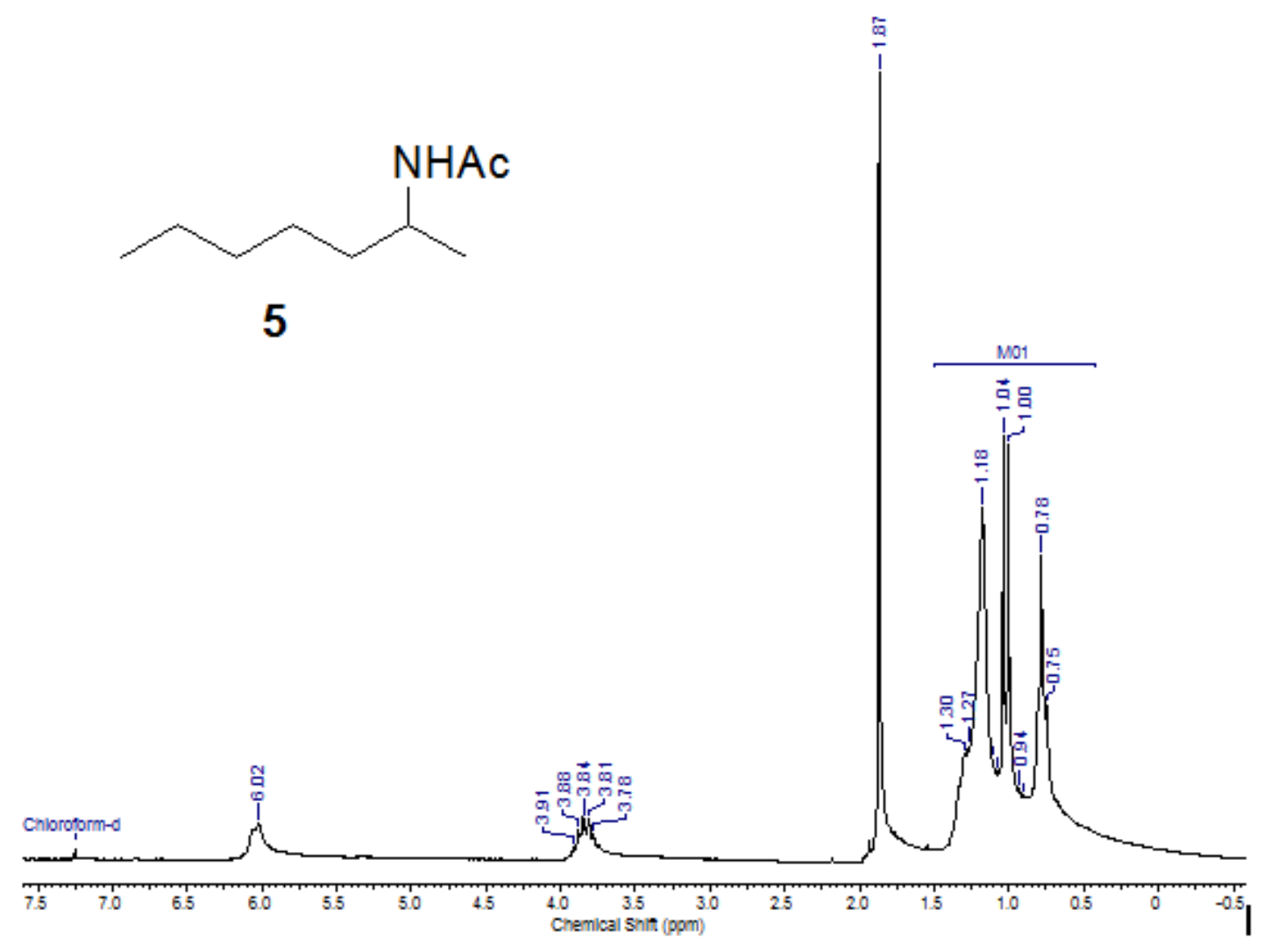


Figura A.2: Espectro de $\mathrm{RMN}$ de ${ }^{13} \mathrm{C}$ da $N$-(1-metil-hexil)acetamida (4) em $\mathrm{CDCl}_{3}$.

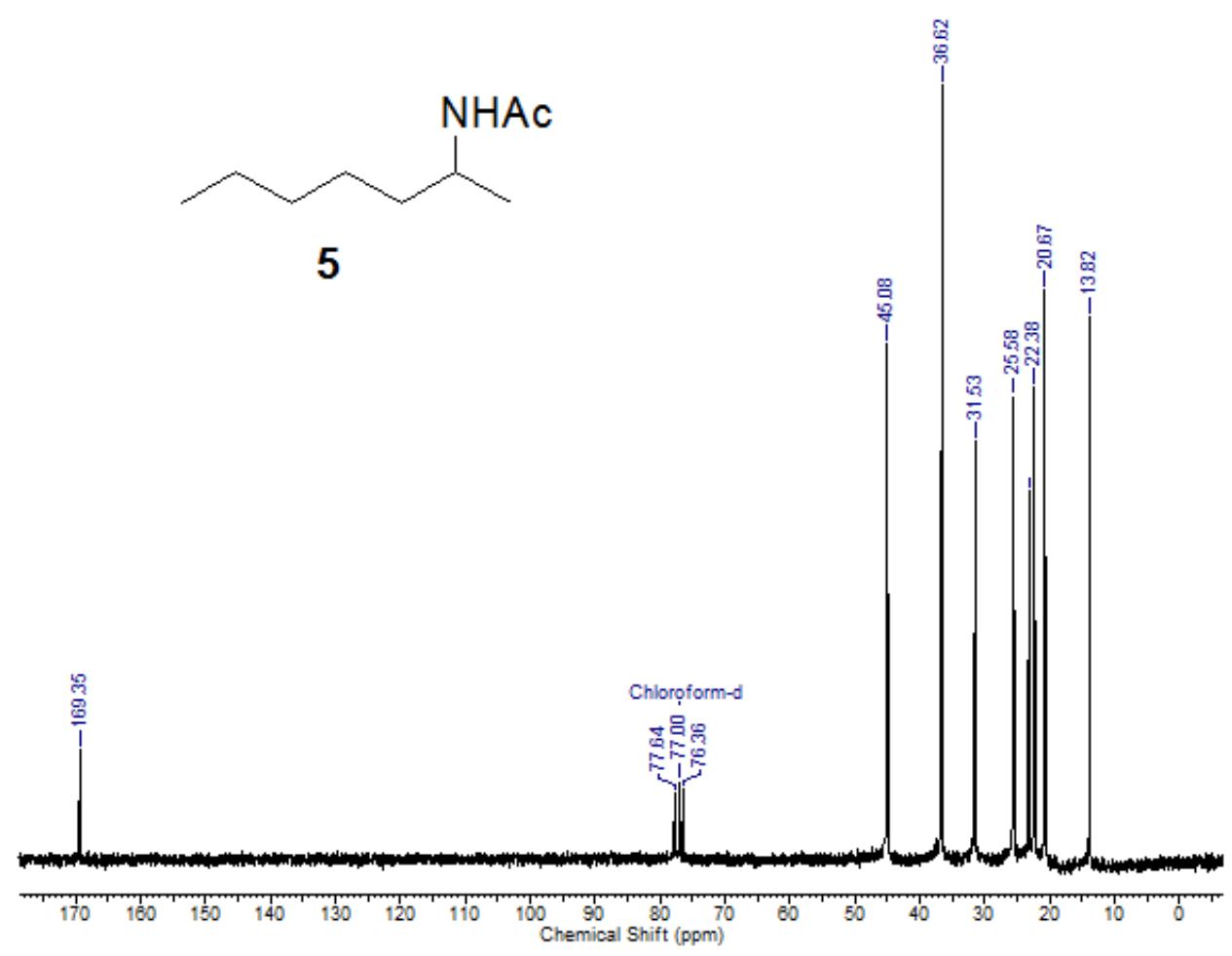

Figura A.3: Espectro de $\mathrm{RMN}$ de ${ }^{1} \mathrm{H}$ da $N$-(2-metil-ciclo-hexil) acetamida (8) em $\mathrm{CDCl}_{3}$.<smiles>CC(C)NC1CCCCC1C</smiles>

8

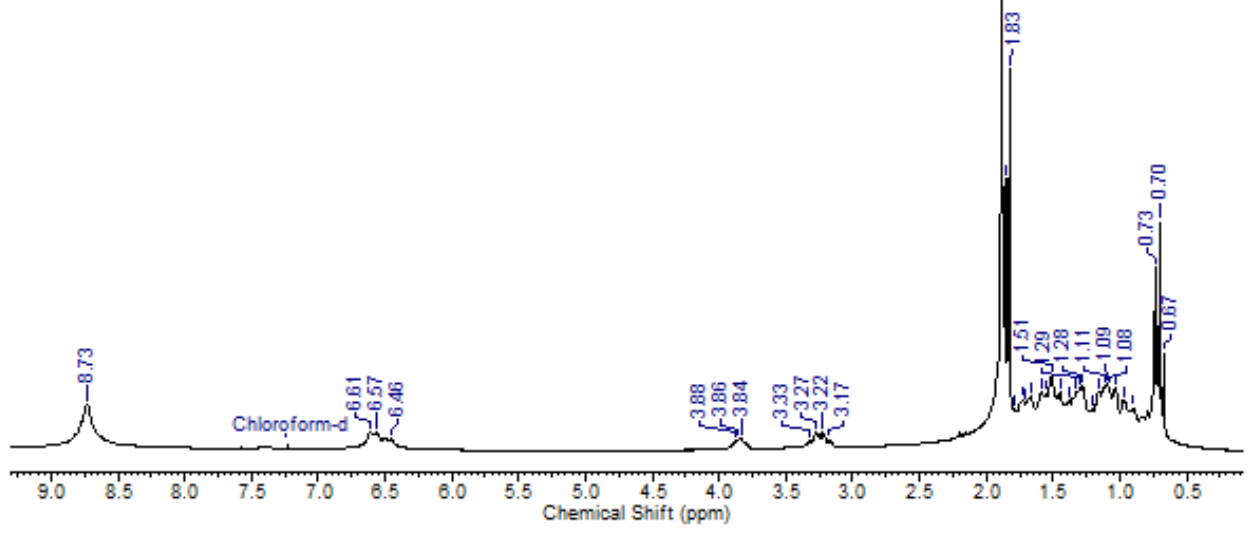


Figura A.4: Espectro de $\mathrm{RMN}$ de ${ }^{13} \mathrm{C}$ da $N$-(2-metil-ciclo-hexil) acetamida (8) em $\mathrm{CDCl}_{3}$.

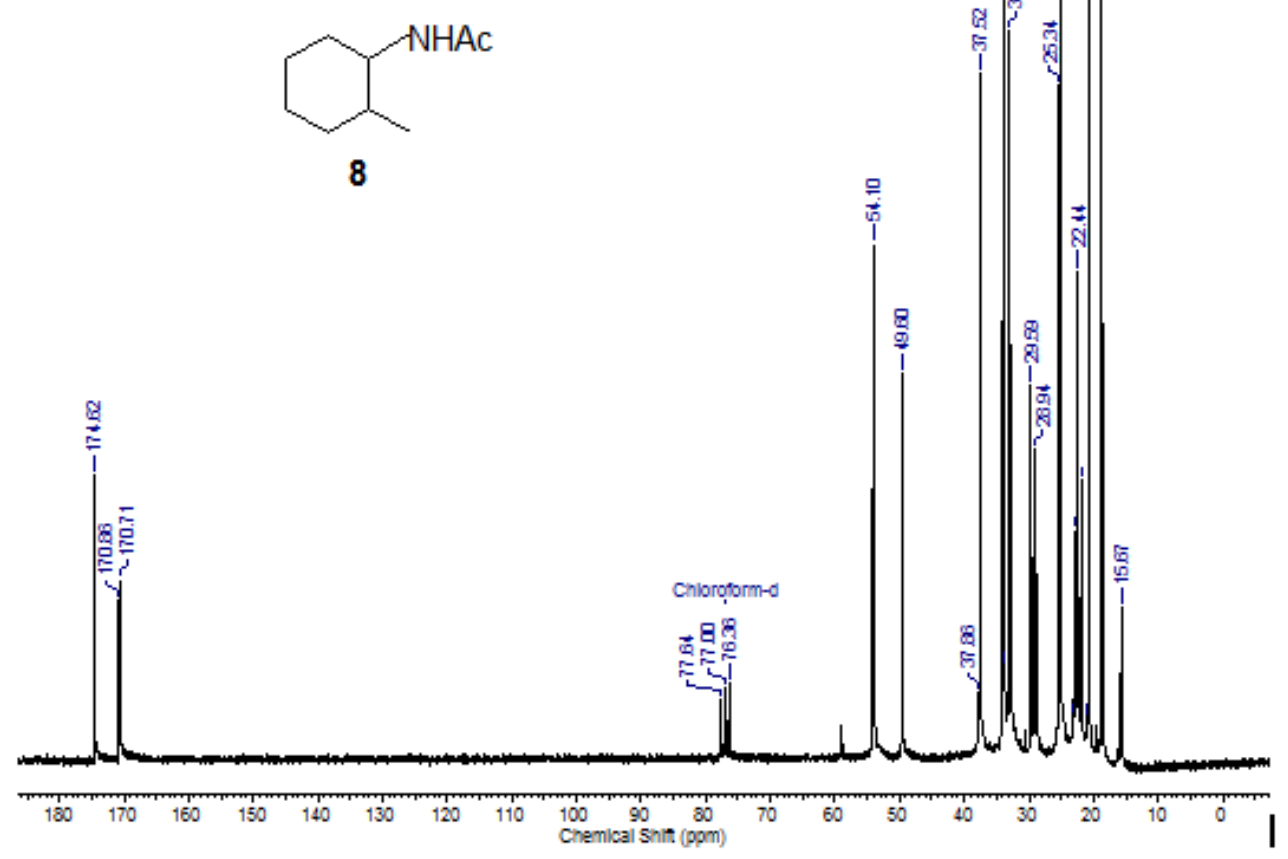

Figura A.5: Espectro de $\mathrm{RMN}$ de ${ }^{1} \mathrm{H}$ da $N$-(1-metil-3-fenilpropil) acetamida (6) em $\mathrm{CDCl}_{3}$.

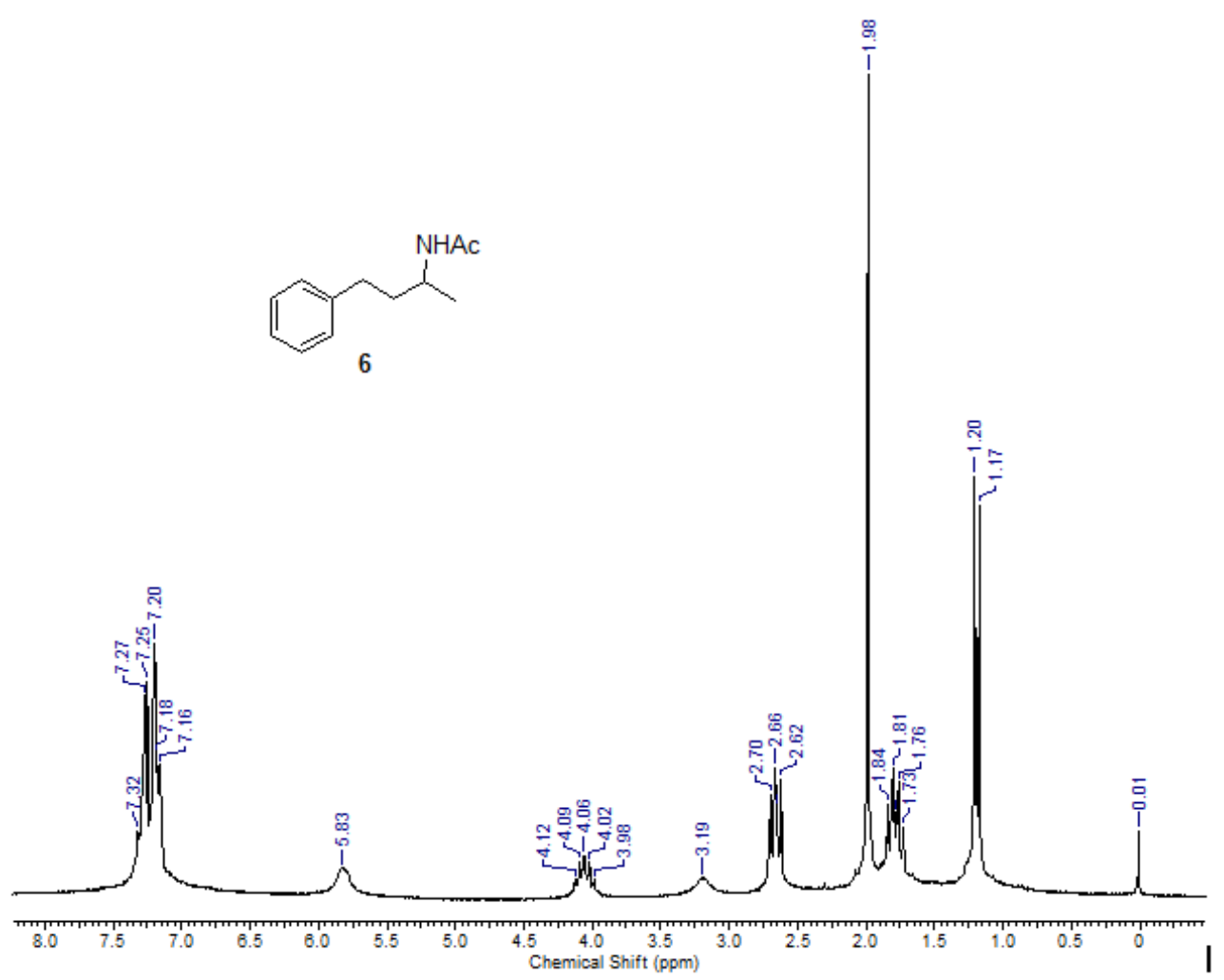


Figura A.6: Espectro de RMN de ${ }^{13} \mathrm{C}$ da $N$-(1-metil-3-fenilpropil) acetamida (6) em $\mathrm{CDCl}_{3}$.

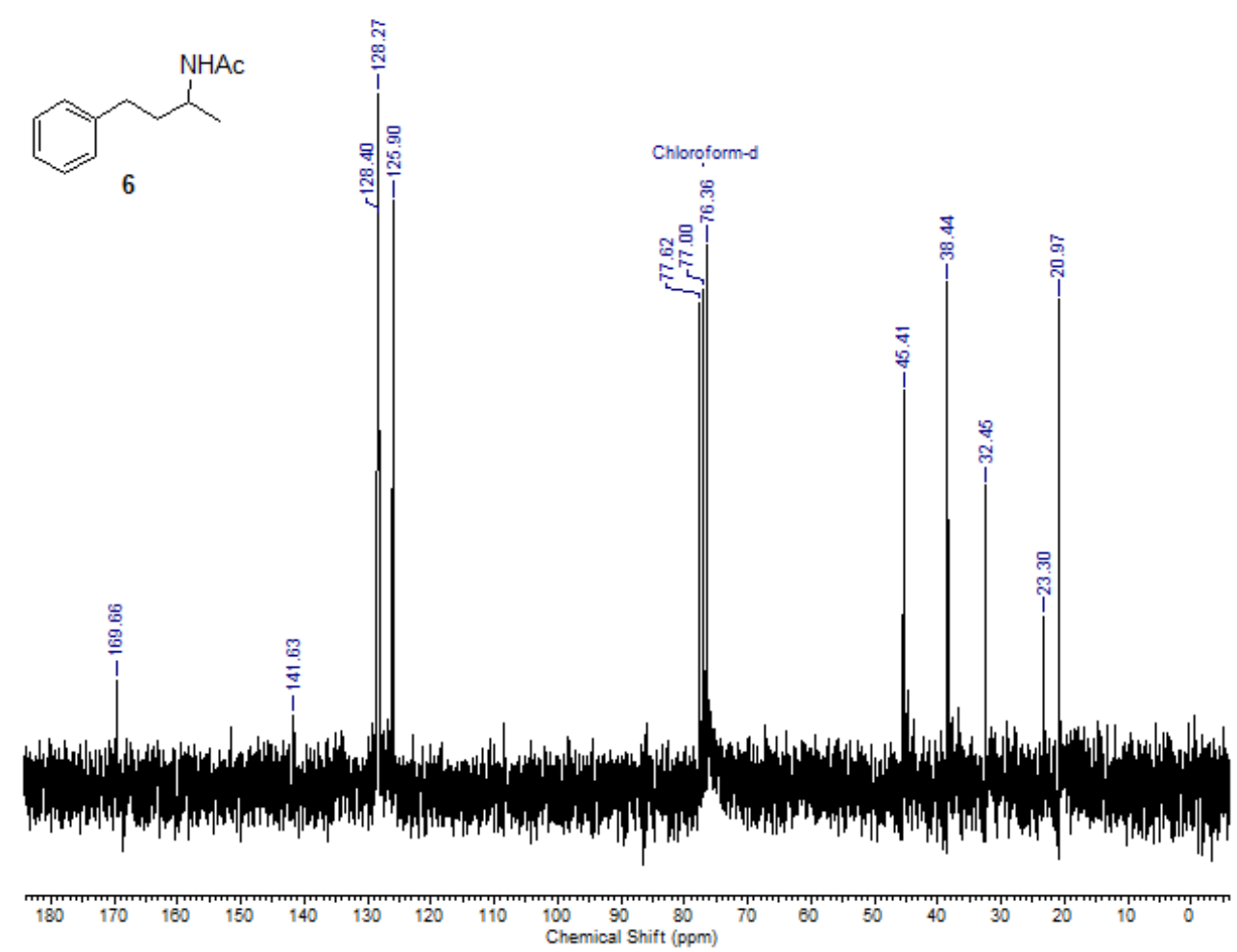

Figura A.7: Espectro de $\mathrm{RMN}$ de ${ }^{1} \mathrm{H}$ da $N$-(1,2,3,4-tetra-hidronaftaleno) acetamida (7) em $\mathrm{CDCl}_{3}$.
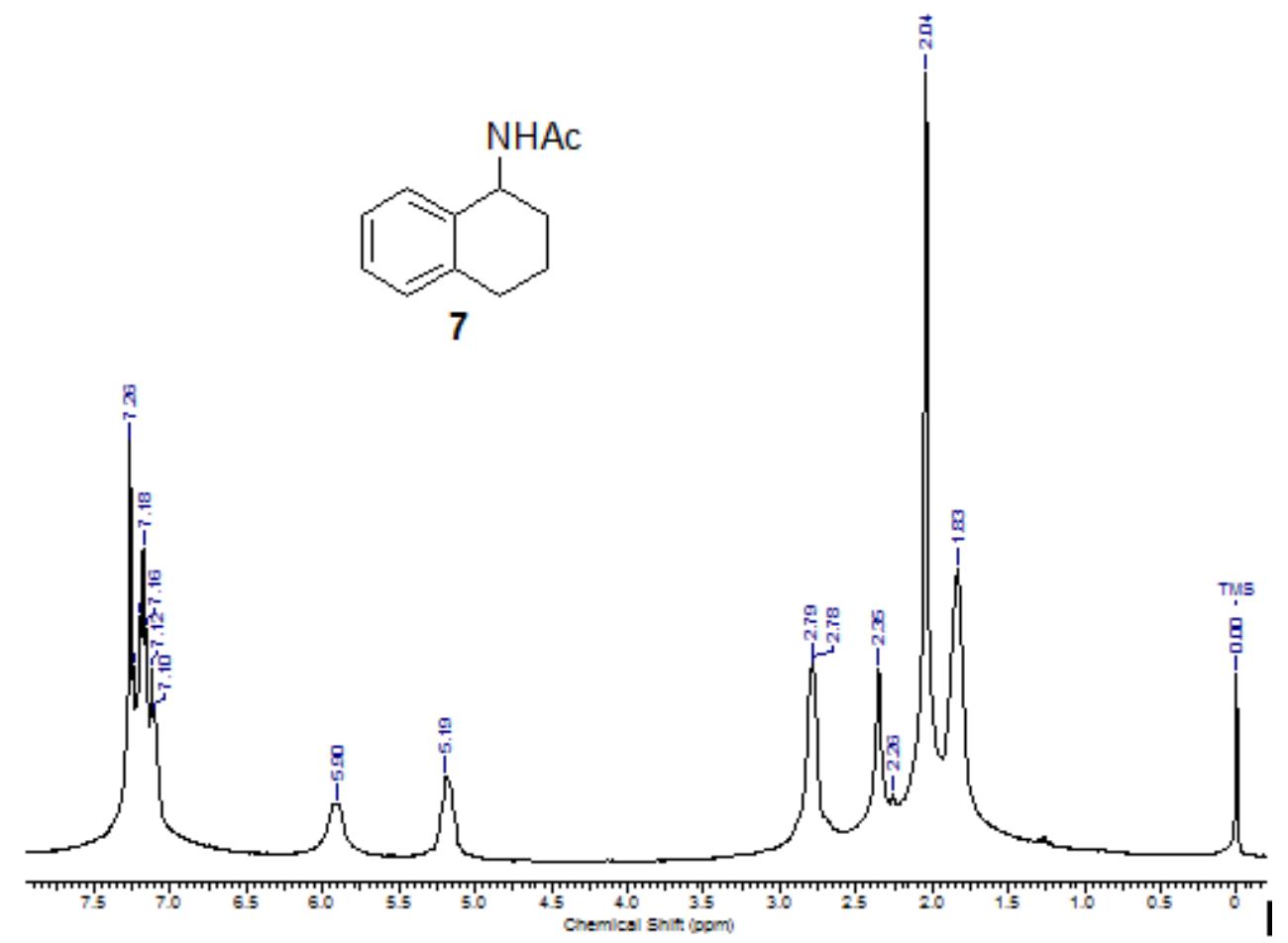
Figura A.8: Espectro de $\mathrm{RMN}$ de ${ }^{13} \mathrm{C}$ da $N$-(1,2,3,4-tetra-hidronaftaleno) acetamida (7) em $\mathrm{CDCl}_{3}$.<smiles>CC(C)(C)NC1CCCc2ccccc21</smiles>

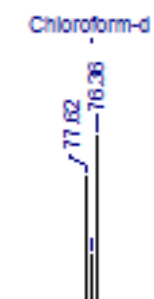

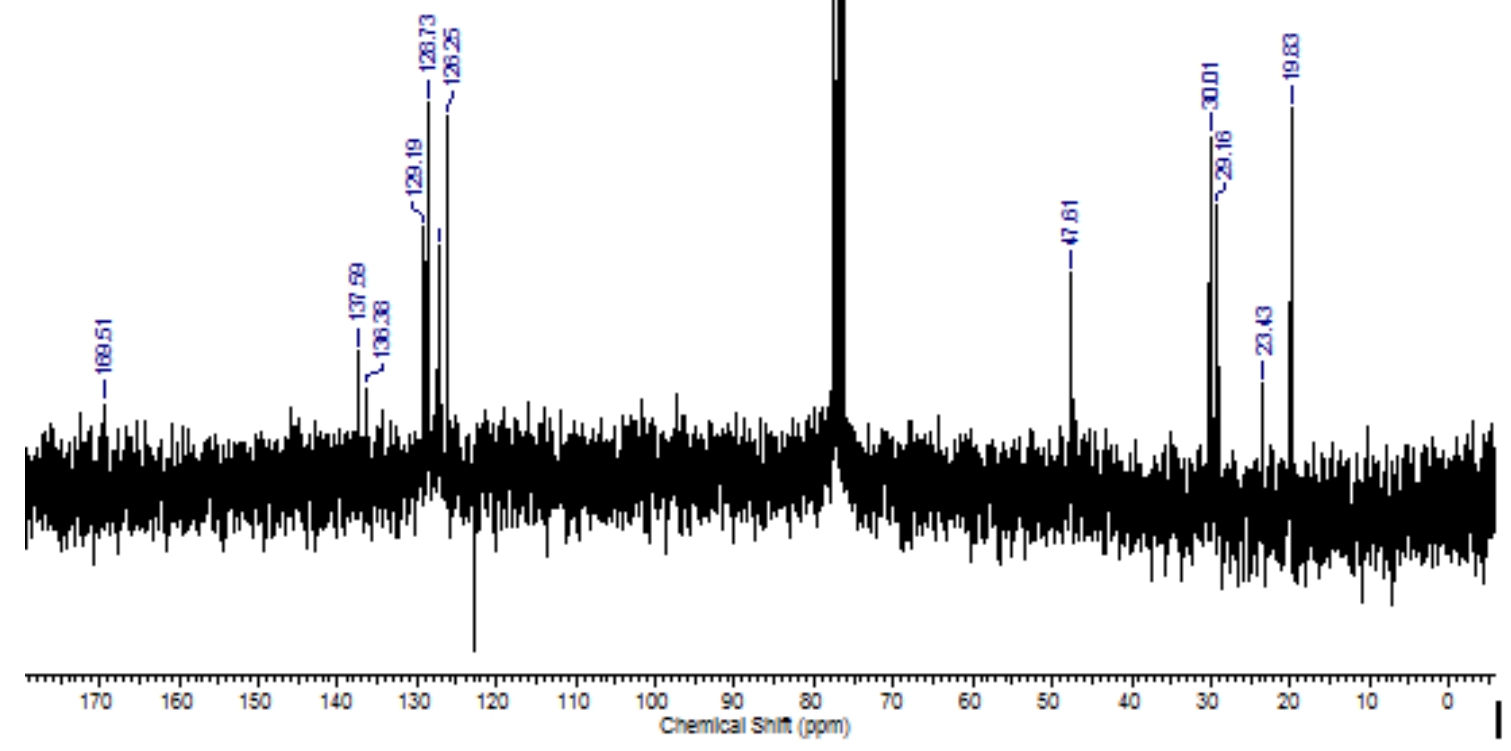




\section{A.2 Nitrilas}

Figura A.9: $\quad$ Espectro de $\quad \mathrm{RMN}$ de ${ }^{1} \mathrm{H}$ da 3 -[(1-metilhexil)aminolpropanonitrila (9) em $\mathrm{CDCl}_{3}$.

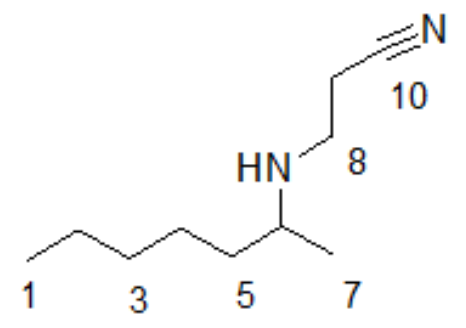

9

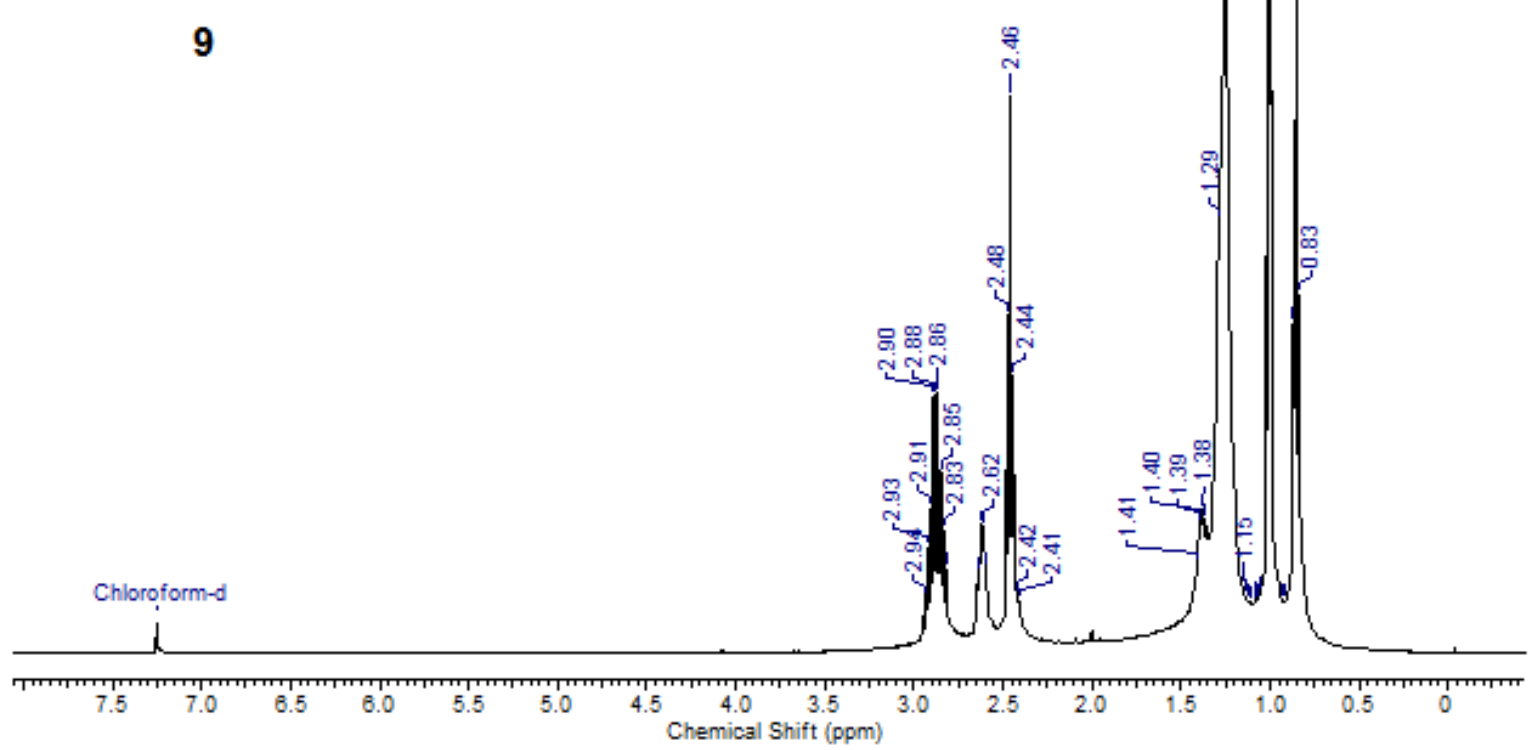


Figura A.10: Espectro de $\mathrm{RMN}$ de ${ }^{13} \mathrm{C}$ da 3-[(1-metilhexil)amino]propanonitrila (9) em $\mathrm{CDCl}_{3}$.

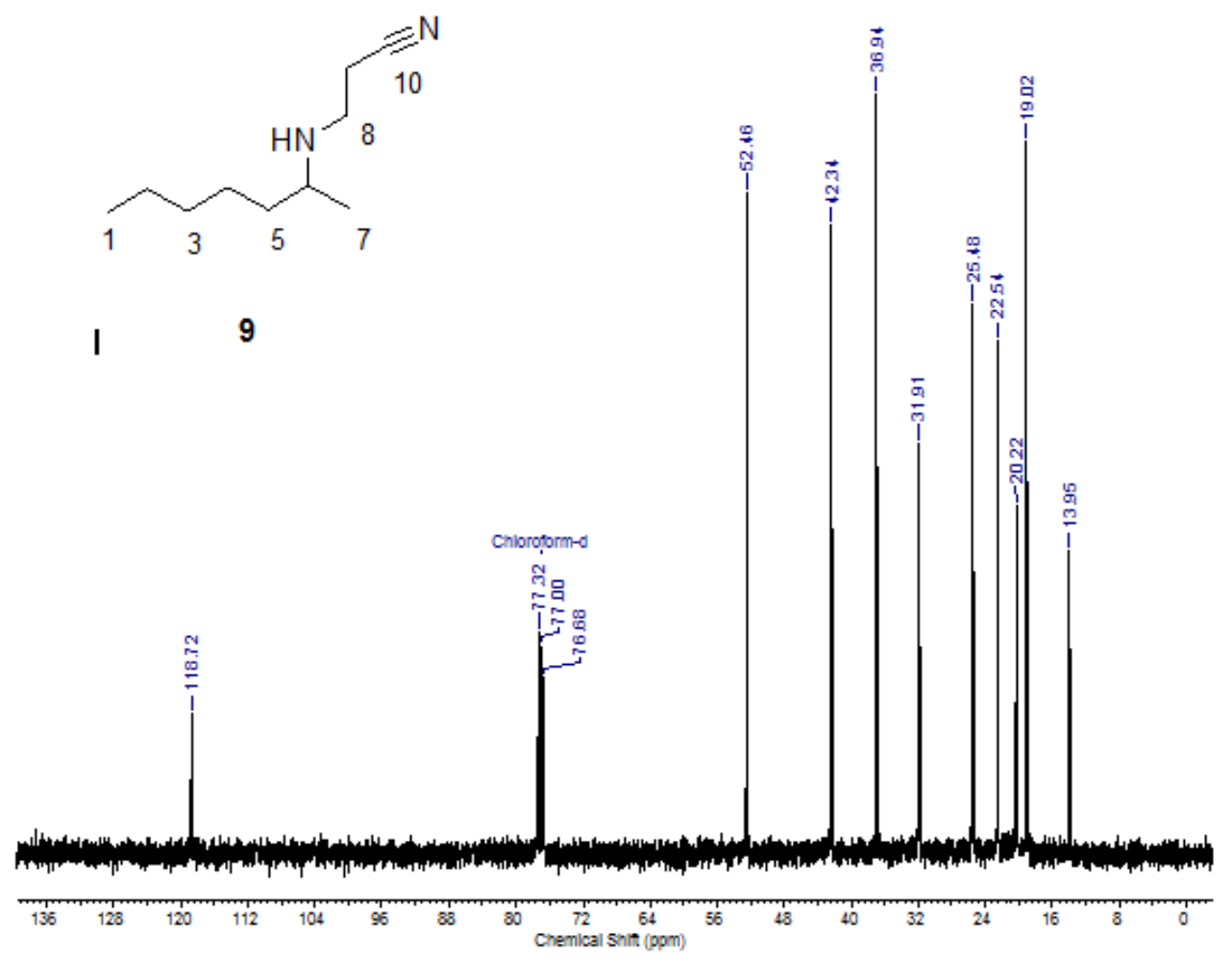

Figura A.1 1: Espectro de $\mathrm{RMN}$ de ${ }^{1} \mathrm{H}$ da 3-[(1-metil-3-fenilpropil)amino] propanonitrila (10) em $\mathrm{CDCl}_{3}$.
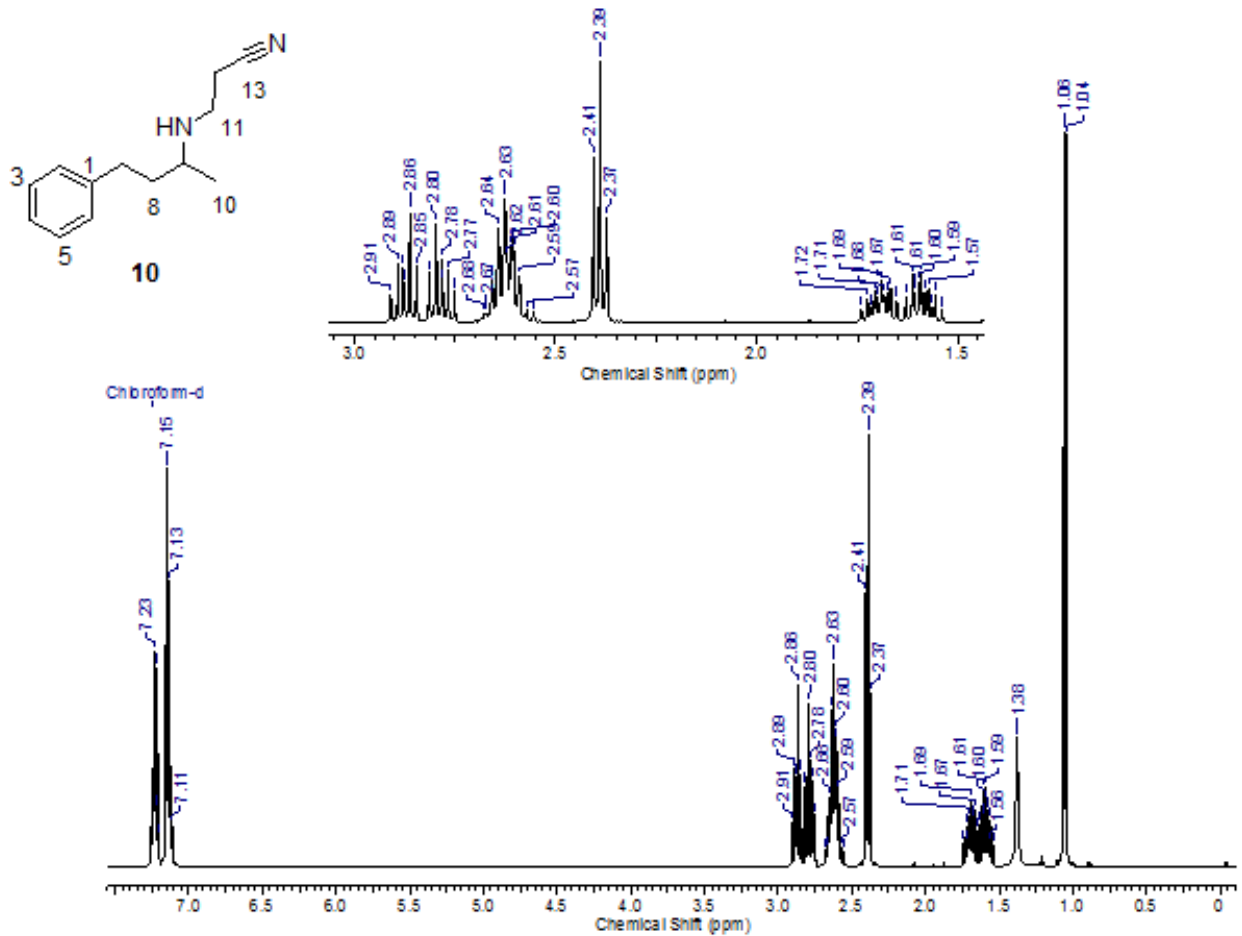
Figura A.12: Espectro de RMN de ${ }^{13} \mathrm{C}$ da 3-[(1-metil-3-fenilpropil)amino] propanonitrila (10) em $\mathrm{CDCl}_{3}$.

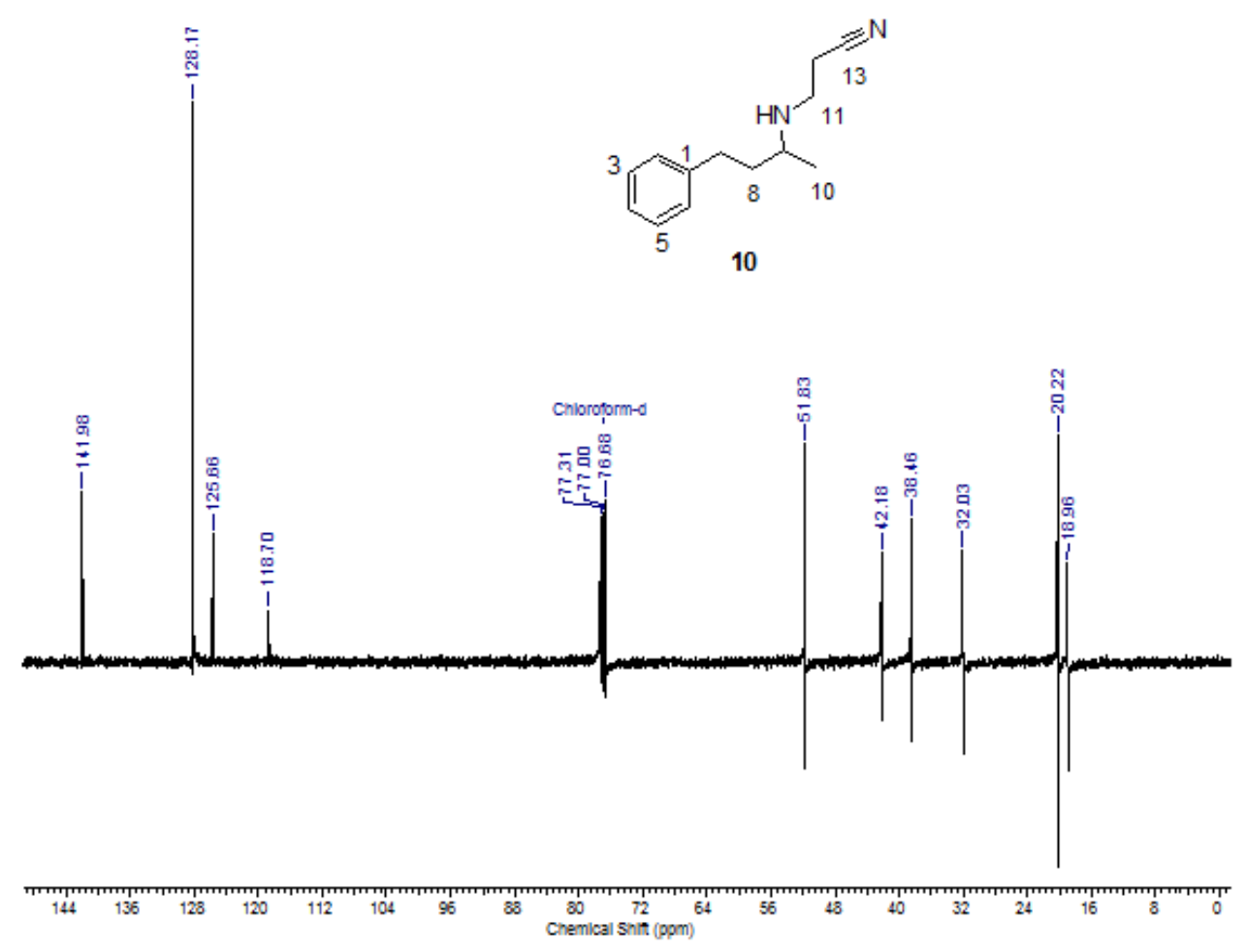

Figura A.13: Espectro de $\mathrm{RMN}$ de ${ }^{1} \mathrm{H}$ da $3-[(2-m e t i l$ cicloexil)aminolpropanonitrila (11) em $\mathrm{CDCl}_{3}$.
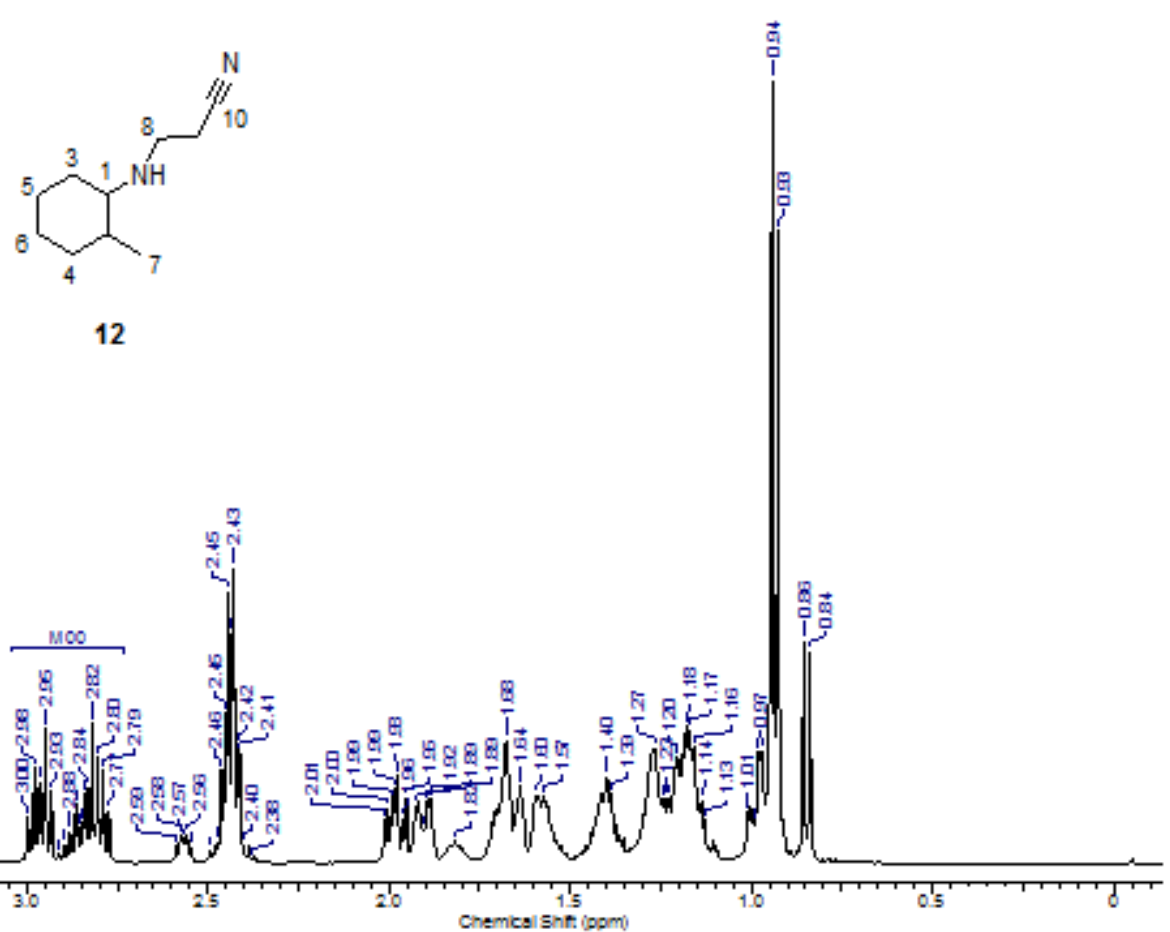
Figura A.14: Espectro de $\mathrm{RMN}$ de ${ }^{13} \mathrm{C}$ da $3-[(2-\mathrm{metil}$ cicloexil)amino]propanonitrila (11) em $\mathrm{CDCl}_{3}$.
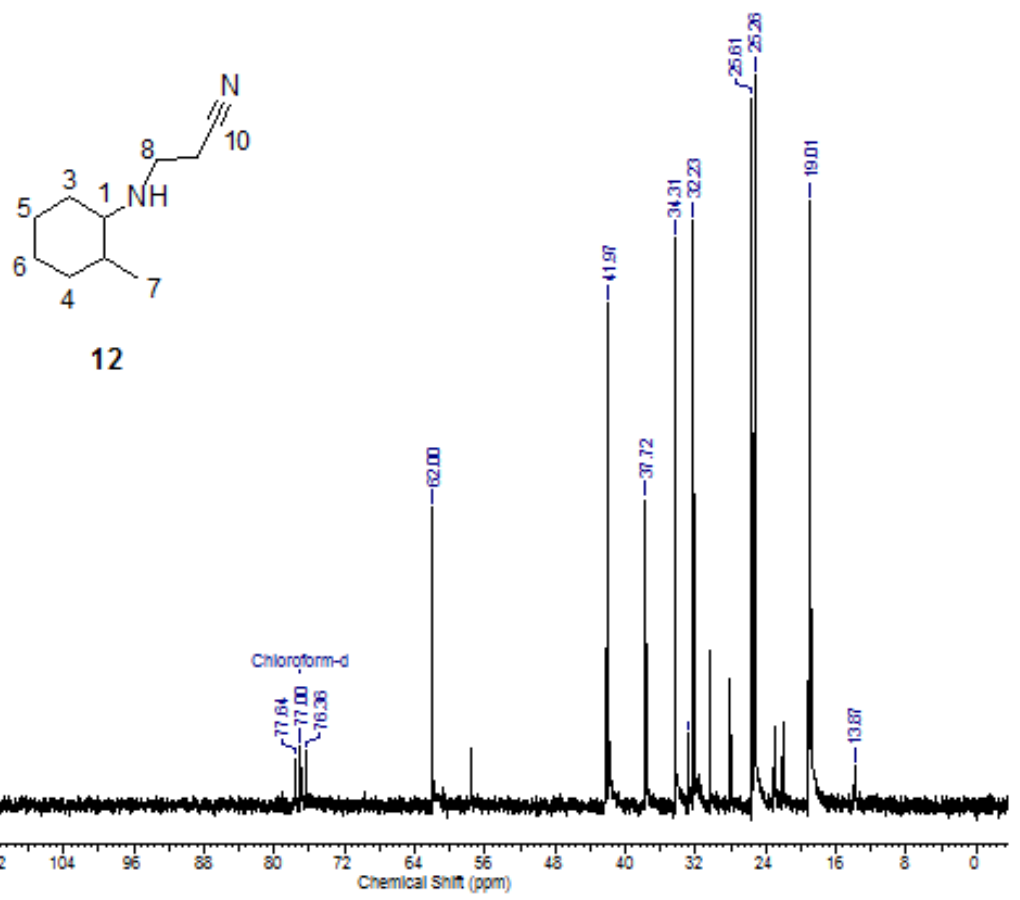

Figura A. 15: Espectro de $\mathrm{RMN}$ de ${ }^{1} \mathrm{H}$ da 3-(1,2,3,4-tetra-hidronaftaleno1-amino) propanonitrila (12) em $\mathrm{CDCl}_{3}$.

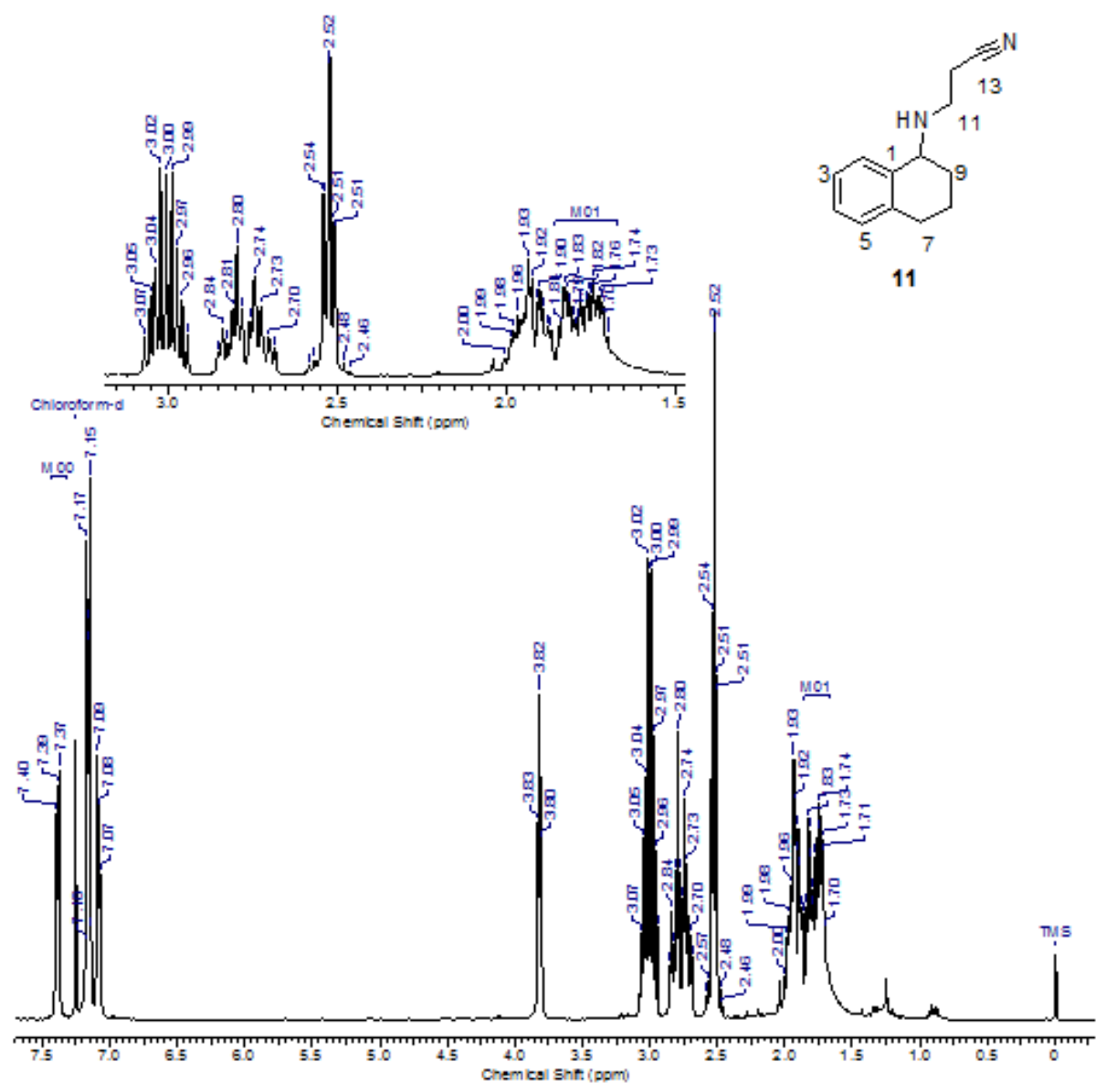


Figura A.16: Espectro de $\mathrm{RMN}$ de ${ }^{13} \mathrm{C}$ da 3-(1,2,3,4-tetrahidronaftaleno-1-amino) propanonitrila (12) em $\mathrm{CDCl}_{3}$.

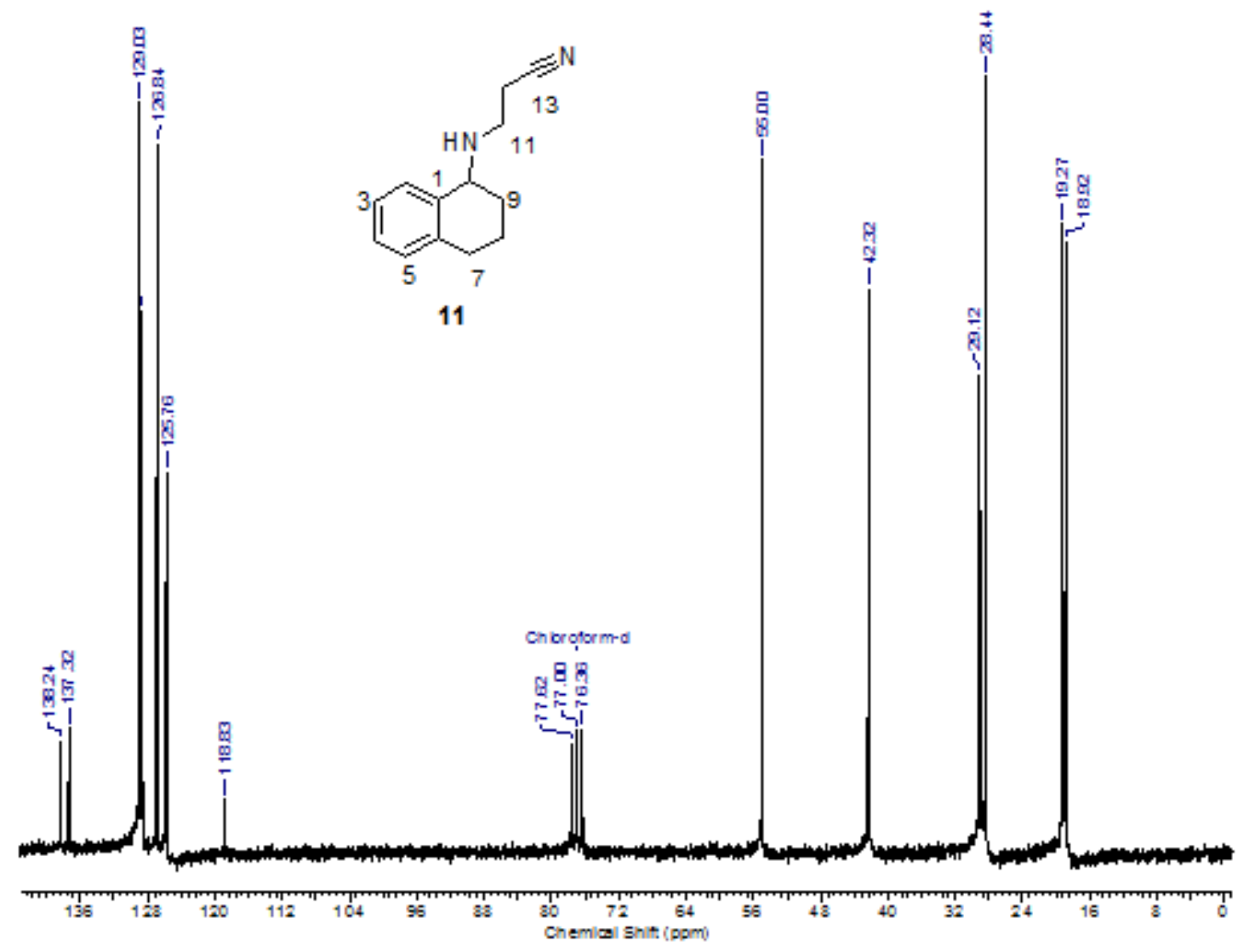




\section{Referências Bibliográficas}

Adam, W., Lukacs, Z., Saha-Möller, C. R., \& Schreier, P. (2000). Biocatalytic kinetic resolution of racemic hydroperoxides through the enantioselective reduction with free and immobilized microorganisms. Journal of the American Chemical Society, 122(20):4887-4892.

Ader, U., Andersch, P., Berger, M., Goergens, U., Seemayer, R., \& Schneider, M. (1992). Hydrolases in organic synthesis: preparation of enantiomerically pure compounds. ChemInform, 23(43).

AMA (2005). Geometric isomerism and chirality: the usan perspective. Disponivel em: <http://www.ama-assn. org/ama/pub/physician-resources/medical-science/ united-states-adopted-names-council/naming-guidelines/ geometric-isomerism-chirality-the-usan-perspective.pagel>. Acesso em: 12 janeiro 2013.

Anand, K., Pal, D., \& Hilgenfeld, R. (2002). An overview on 2-methyl-2, 4pentanediol in crystallization and in crystals of biological macromolecules. Acta Crystallographica Section D: Biological Crystallography, 58(10):17221728.

Araujo, M. (2010). Bacillus subtilis. Disponivel em: <http://www. infoescola.com/reino-monera/bacillus-subtilis/>. Acesso em: 12 novembro 2012.

Arizona, U. (2013). Yeast alcohol dehydrogenase. Disponível em: <http:// www.biochem.arizona.edu/classes/bioc463a/molecular_graphics_ gallery/jmol/Alcohol\%20Dehydrogenase_M/webexample.html>. Acesso em: 13 janeiro 2013 . 
Armarego, W. \& Chai, C. (2009). Purification of laboratory chemicals. Butterworth-Heinemann is.

Barreiro, E., Ferreira, V., \& Costa, P. (1997). Substâncias enantiomericamente puras (sep): a questão dos fármacos quirais. Química Nova, Rio de Janeiro, 6(20):647-656.

Batmanian, L., Batmanian, W., Worrall, S., \& Ridge, J. (2009). Biochemistry for Health Professionals. Elsevier Australia.

Baudoin, O., Cesario, M., Guenard, D., \& Guéritte, F. (2002). Application of the palladium-catalyzed borylation/suzuki coupling (bsc) reaction to the synthesis of biologically active biaryl lactams. The Journal of Organic Chemistry, 67(4):1199-1207.

Bejugam, M. \& Flitsch, S. (2004). An efficient synthetic route to glycoamino acid building blocks for glycopeptide synthesis. Organic letters, 6(22):40014004.

Berendsen, W., Gendrot, G., Resnick, S., \& Reuss, M. (2006). Kinetic modeling of lipase catalyzed hydrolysis of $(<\mathrm{i}>\mathrm{r}</ \mathrm{i}>/<\mathrm{i}>\mathrm{s}</ \mathrm{i}>)$-1-methoxy-2-propylacetate as a model reaction for production of chiral secondary alcohols. Journal of biotechnology, 121(2):213-226.

Bianchi, D., Cesti, P., \& Battistel, E. (1988). Anhydrides as acylating agents in lipase-catalyzed stereoselective esterification of racemic alcohols. The Journal of Organic Chemistry, 53(23):5531-5534.

Blaser, H. \& Spindler, F. (2000). Hydrogenation of imino groups. ChemInform, $31(18)$.

Bolen, D. (2004). Effects of naturally occurring osmolytes on protein stability and solubility: issues important in protein crystallization. Methods, 34(3):312-322.

Bolm, C., Hildebrand, J., \& Muniz, K. (2000). Recent advances in asymmetric dihydroxylation and aminohydroxylation. Catalytic asymmetric synthesis, page 399 .

Bom, E., Ferrara, M., Corvo, M., Vermelho, A., Paiva, C., Alencastro, R., \& Coelho, R. (2008). Enzimas em biotecnologia: produção, aplicações e mercado. Rio de Janeiro: Interciencia.

Bornscheuer, U. \& Kazlauskas, R. (2006). Front Matter. Wiley Online Library. 
Breuer, M., Ditrich, K., Habicher, T., Hauer, B., Kesseler, M., Stürmer, R., \& Zelinski, T. (2004). Industrial methods for the production of optically active intermediates. Angewandte Chemie International Edition, 43(7):788-824.

Bunders, J., Haverkort, B., Hiemstra, W., et al. (1996). Biotechnology: building on farmers' knowledge. Macmillan.

Cai, Y., Wu, Q., Xiao, Y., Lv, D., \& Lin, X. (2006). Hydrolase-catalyzed michael addition of imidazoles to acrylic monomers in organic medium. Journal of biotechnology, 121(3):330-337.

Caldwell, J. (1995). Stereochemical determinants of the nature and consequences of drug metabolism. Journal of Chromatography A, 694(1):39-48.

Campos, F., Bosch, M., \& Guerrero, A. (2000). An efficient enantioselective synthesis of $(r, r)$-formoterol, a potent bronchodilator, using lipases. Tetrahedron: Asymmetry, 11(13):2705 - 2717.

Castro, H., Mendes, A., dos Santos, J., \& de Aguiar, C. (2004). Modificação de óleos e gorduras por biotransformação. Química Nova, 27(1):146-156.

Chalard, P., Bertrand, M., Canet, I., Thery, V., Remuson, R., \& Jeminet, G. (2000). Determination of absolute configurations of amines and amino acids using nonchiral derivatizing agents (ncda) and deuterium nmr. Organic letters, 2(16):2431-2434.

Chen, C., Fujimoto, Y., Girdaukas, G., \& Sih, C. (1982). Quantitative analyses of biochemical kinetic resolutions of enantiomers. Journal of the American Chemical Society, 104(25):7294-7299.

Coelho, F. (2001). Fármacos e quiralidade. Cadernos Temáticos de Química Nova na Escola (Química de Fármacos), 3:23-32.

Corporation, W. B. (2011). Alcohol dehydrogenase. Disponivel em: <http: //www.worthington-biochem.com/ADH/default.html>. Acesso em: 27 maio 2011.

Costa, N. \& Borém, A. (2003). Biotecnologia e Nutrição: saiba como o DNA pode enriquecer os alimentos. NBL Editora.

Denmark, S. \& Nicaise, O. (2000). Alkylation of imino groups. ChemInform, 31(18). 
Dhake, K., Tambade, P., Singhal, R., \& Bhanage, B. (2010). Promiscuous $<\mathrm{i}>$ candida antarctica $</ \mathrm{i}>$ lipase $\mathrm{b}$-catalyzed synthesis of $\beta$-amino esters via aza-michael addition of amines to acrylates. Tetrahedron Letters, 51(33):4455-4458.

dos Santos, A., Pinheiro, A., Sodero, A., da Cunha, A., Padilha, M., de Sousa, P., Fontes, S., Veloso, M., \& Fraga, C. (2007). Atropoisomerismo: o efeito da quiralidade axial em substâncias bioativas. Química Nova, 30(1):125.

Drauz, K., Waldmann, H., \& Theil, F. (1996). Enzyme catalysis in organic synthesis, vols. 1 and 2-a comprehensive handbook. Angewandte ChemieGerman Edition, 108(8):989-989.

Dyck, L., Davis, B., Liu, Y., Durden, D., Boulton, A., et al. (2006). Aliphatic amino carboxylic and amino phosphonic acids amino nitriles and amino tetrazoles as cellular rescue agents. US Patent 6,984,754.

Farah, S. (2000). Dna: segredos e mistérios; dna: secrets and mysteries. page 273.

Francotte, E., Lindner, W., Mannhold, R., Kubinyi, H., \& Folkers, G. (2007). Chirality in Drug Research. Methods and Principles in Medicinal Chemistry. John Wiley \& Sons.

Gal, J. (2010). Louis pasteur, language, and molecular chirality. i. background and dissymmetry. Chirality, 23(1):1-16.

Garcia, H., Storkson, J., Pariza, M., \& Hill, C. (1998). Enrichment of butteroil with conjugated linoleic acid via enzymatic interesterification (acidolysis) reactions. Biotechnology letters, 20(4):393-395.

Garcia, R., Garcia, T., Martinez, M., \& Aracil, J. (2000). Kinetic modelling of the synthesis of 2-hydroxy-5-hexenyl 2-chlorobutyrate ester by an immobilised lipase. Biochemical engineering journal, 5(3): 185-190.

Garcia-Urdiales, E., Rebolledo, F., \& Gotor, V. (2000). Enzymatic one-pot resolution of two nucleophiles: alcohol and amine. Tetrahedron: Asymmetry, $11(7): 1459-1463$.

Gonzalez-Sabin, J., Gotor, V., \& Rebolledo, F. (2002). Cal-b-catalyzed resolution of some pharmacologically interesting $\beta$-substituted isopropylamines. Tetrahedron: Asymmetry, 13(12):1315-1320. 
Gorske, B., Jewell, S., Guerard, E., \& Helen, E. (2005). Expedient synthesis and design strategies for new peptoid construction. Organic Letters, 7(8):1521-1524.

Gröger, H., Hummel, W., Buchholz, S., Drauz, K., Van Nguyen, T., Rollmann, C., Hüsken, H., \& Abokitse, K. (2003). Practical asymmetric enzymatic reduction through discovery of a dehydrogenase-compatible biphasic reaction media. Organic letters, 5(2):173-176.

Grunwald, P. (2009). Biocatalysis: biochemical fundamentals and applications. World Scientific Publishing Company Incorporated.

Harwood, C. (1992). Bacillus subtilis and its relatives: molecular biological and industrial workhorses. Trends in biotechnology, 10:247-256.

Heller, H. C., Orians, G. H., \& Purves, W. K. (1998). Life: The Science of Biology. W. H. Freeman; Fourth Edition edition.

HENEGARIU, O. (1997). Pcr and multiplex pcr: guide and troubleshooting. Disponível em: <http://medicine.yale.edu/labs/henegariu/ www/tavi/PCR.html>. Acesso em: 12 novembro 2012.

Hieber, G. \& Ditrich, K. (2001). Introducing chipros: Biocatalytic production of chiral intermediates on a commercial scale. Chimica oggi, 19(6):16-20.

Hirata, H., Kawanishi, M., Iwata, Y., Sakaki, K., \& Yanagishita, H. (2007). Kinetic studies on lipase-catalyzed acetylation of 2-alkanol with vinyl acetate in organic solvent. Journal of oleo science, 56(6):309-317.

Hult, K. \& Berglund, P. (2007). Enzyme promiscuity: mechanism and applications. TRENDS in Biotechnology, 25(5):231-238.

Hyneck, M., Dent, J., \& Hook, J. (1990). Chirality: pharmacological action and drug development.

Imanzadeh, G., Zare, A., Khalafi-Nezhad, A., Hasaninejad, A., Moosavi Zare, A., \& Parhami, A. (2007). Microwave-assisted michael addition of sulfonamides to $\alpha, \beta$-unsaturated esters: A rapid entry to protected $\beta$-amino acid synthesis. Journal of the Iranian Chemical Society, 4(4):467-475.

Jaeger, K., Dijkstra, B., \& Reetz, M. (1999). Bacterial biocatalysts: molecular biology, three-dimensional structures, and biotechnological applications of lipases. Annual Reviews in Microbiology, 53(1):315-351. 
Jaeger, K. \& Eggert, T. (2002). Lipases for biotechnology. Current opinion in Biotechnology, 13(4):390-397.

Jaeger, K., Ransac, S., Dijkstra, B., Colson, C., van Heuvel, M., \& Misset, O. (1994). Bacterial lipases. FEMS microbiology reviews, 15(1):29-63.

Johnson, A. (1999). Invitation to Organic Chemistry. Jones \& Bartlett Learning.

Jung, H., Koh, J., Kim, M., \& Park, J. (2000). Practical ruthenium/lipasecatalyzed asymmetric transformations of ketones and enol acetates to chiral acetates. Organic Letters, 2(16):2487-2490.

Kall, A., Bandyopadhyay, D., \& Banik, B. (2010). Microwave-induced azamichael reaction in water: A remarkably simple procedure. Synthetic Communications@, 40(12):1730-1735.

Kappe, C. (2004). Controlled microwave heating in modern organic synthesis. Angewandte Chemie International Edition, 43(46):6250-6284.

Kim, M., Kim, W., Han, K., Choi, Y., \& Park, J. (2007). Dynamic kinetic resolution of primary amines with a recyclable pd nanocatalyst for racemization. Organic letters, 9(6): 1157-1159.

Kirilin, A., Sahin, S., Mäki-Arvela, P., Wärnå, J., Salmi, T., \& Murzin, D. (2010). Kinetics and modeling of (r, s)-1-phenylethanol acylation over lipase. International Journal of Chemical Kinetics, 42(10):629-639.

Klibanov, A. (1989). Enzymatic catalysis in anhydrous organic solvents. Trends in Biochemical Sciences, 14(4):141-144.

Laurent, A., Laurent, ., Locher, P., \& Mison, P. (1972). Désamination nitreuse en milieu aprotique méthyl-2 cyclohexylamines. Bulletin de la Societe Chimique de France, 4:1369-1374.

Li, C., Tan, T., Zhang, H., \& Feng, W. (2010). Analysis of the conformational stability and activity of candida antarctica lipase b in organic solvents insight from molecular dynamics and quantum mechanics/simulations. Journal of Biological Chemistry, 285(37):28434-28441.

Lima, V. (1997). Os fármacos e a quiralidade: uma breve abordagem. Química Nova, 20(6):657-663.

Lisby, G. (1999). Application of nucleic acid amplification in clinical microbiology. Molecular biotechnology, 12(1):75-99. 
Mateo, C., Palomo, J., Fernandez-Lorente, G., Guisan, J., \& FernandezLafuente, R. (2007). Improvement of enzyme activity, stability and selectivity via immobilization techniques. Enzyme and Microbial Technology, 40(6): 1451-1463.

Matsushita, T., Hinou, H., Fumoto, M., Kurogochi, M., Fujitani, N., Shimizu, H., \& Nishimura, S. (2006). Construction of highly glycosylated mucin-type glycopeptides based on microwave-assisted solid-phase syntheses and enzymatic modifications. The Journal of Organic Chemistry, 71(8):3051-3063.

Mattos, M. \& Marzorati, L. (1999). Aspectos mecanísticos da adição de michael. Química Nova, 22(5):710-714.

Mavandadi, F. \& Pilotti, A. (2006). The impact of microwave-assisted organic synthesis in drug discovery. Drug discovery today, 11(3):165-174.

Michaux, C., Pomroy, N., \& Privé, G. (2008). Refolding sds-denatured proteins by the addition of amphipathic cosolvents. Journal of molecular biology, 375(5): 1477-1488.

Monsalve, L., Gillanders, F., \& Baldessari, A. (2012). Promiscuous behavior of rhizomucor miehei lipase in the synthesis of $\mathrm{n}$-substituted $\beta$-amino esters. European Journal of Organic Chemistry, 2012(6):1164-1170.

Mouad, A., Martins, M., Debonsi, H., de Oliveira, A., de Felicio, R., Yokoya, N., Fujii, M., de Menezes, C., Fantinatti-Garboggini, F., \& Porto, A. (2011). Bioreduction of acetophenone derivatives by red marine algae bostrychia radicans and b. tenella, and marine bacteria associated. Helvetica Chimica Acta, 94(8):1506-1514.

Murray, J. \& Gellman, S. (2005). Application of microwave irradiation to the synthesis of 14-helical b-peptides. Organic letters, 7(8):1517-1520.

Narayanan, C. \& Sawant, B. (1971). Conformation of the carbonyl group in secondary amides. Tetrahedron Letters, 12(18):1321-1324.

Nawani, N., Singh, R., \& Kaur, J. (2006). Immobilization and stability studies of a lipase from thermophilic bacillus sp: The effect of process parameters on immobilization of enzyme. Electronic Journal of Biotechnology, 9(5).

Nechab, M., Azzi, N., Vanthuyne, N., Bertrand, M., Gastaldi, S., \& Gil, G. (2007). Highly selective enzymatic kinetic resolution of primary amines at 80 c: a comparative study of carboxylic acids and their ethyl esters as acyl donors. The Journal of Organic Chemistry, 72(18):6918-6923. 
Nelson, D. et al. (2001). Lehninger princípios de bioquímica. Omega.

Nugent, T. (2010). Chiral Amine Synthesis. Wiley.

Nussbaum, R., McInnes, R., \& Willard, H. (2007). Thompson \& Thompson Genetics in Medicine (E-Rental - No Student Consult access). Elsevier Health Sciences.

ORT, I. D. T. (2011). O que é biotecnologia. Disponivel em: <http:/ / www . ort . org.br/biotecnologia/o-que-e-biotecnologia>. Acesso em: 20 maio 2011.

Pandey, A., Benjamin, S., Soccol, C. R., Nigam, P., Krieger, N., \& Soccol, V. T. (1999). The realm of microbial lipases in biotechnology. Biotechnology and Applied Biochemistry, 29(2): 119-131.

Pessoa, H., González, M., González, M., Pessoa, D., Araya Maturana, R., Higuera, R., \& Betsabé, N. (2009). Solvent-free microwave-promoted michael addition of aza-nucleophiles to benzo [b] thiophen-2-yl-2-propenone. ARKIVOC, xi.

PhotoLibrary, S. (2012). Bacillus subtilis. Disponivel em: <http://www . sciencephoto.com/media/12288/enlarge>. Acesso em: 12 novembro 2012.

PORTAL, O. C. (2011). Adh, alcohol dehydrogenase. Disponível em: <http://www.organic-chemistry.org/chemicals/reductions/ alcoholdehydrogenase-adh. shtm>. Acesso em: 30 maio 2011.

Reddy, I. \& Mehvar, R. (2004). Chirality in drug design and development. Marcel Dekker.

Reetz, M. (2002). Directed evolution of selective enzymes and hybrid catalysts. Tetrahedron, 58(32):6595-6602.

Regateiro, F. (2003). Manual de Genética Médica. Imprensa da Universidade.

Réjasse, B., Lamare, S., Legoy, M., \& Besson, T. (2004). Stability improvement of immobilized candida antarctica lipase $\mathrm{b}$ in an organic medium under microwave radiation. Org. Biomol. Chem., 2(7):1086-1089.

Rocha, L., Rosset, I., Luiz, R., Raminelli, C., \& Porto, A. (2010). Kinetic resolution of iodophenylethanols by candida antarctica lipase and their application for the synthesis of chiral biphenyl compounds. Tetrahedron: Asymmetry, 21(8):926-929. 
Romero, J. (1998). Fundamentos de esteroquímica dos compostos orgânicos. pages 15-24.

Rouhi, A. M. (2003). Fine chemicals companies are jockeying for position to deliver the increasingly complicated chiral small molecules of the future. Chemical and Engineering News, 81(18):45-61.

Saifuddin, N. \& Raziah, A. (2008). Enhancement of lipase enzyme activity in non-aqueous media through a rapid three phase partitioning and microwave irradiation. Journal of Chemistry, 5(4):864-871.

Sambrook, J. \& Russell, D. (2001). Molecular cloning: a laboratory manual, volume 1. CSHL press.

Sarfati, J. (1998). Origin of life: the chirality problem. Technical Journal, 12(3):263-266.

SCHMID, A., DORDICK, J., HAUER, B., KIENER, A., WUBBOLTS, M., \& WITHOLT, B. (2001). Industrial biocatalysis today and tomorrow. Nature, 409(6817):258-268.

Secundo, F., Riva, S., \& Carrea, G. (1992). Effects of medium and of reaction conditions on the enantioselectivity of lipases in organic solvents and possible rationales. Tetrahedron: asymmetry, 3(2):267-280.

Seeman, J. (1983). Effect of conformational change on reactivity in organic chemistry. evaluations, applications, and extensions of curtin-hammett winstein-holness kinetics. Chemical Reviews, 83(2):83-134.

Sehanputri, P. S. \& Hill, C. G. (1999). Biotechnology for the production of nutraceuticals enriched in conjugated linoleic acid: I. uniresponse kinetics of the hydrolysis of corn oil by a pseudomonas sp. lipase immobilized in a hollow fiber reactor. Biotechnology and Bioengineering, 64(5).

Sharma, R., Chisti, Y., \& Banerjee, U. (2001). Production, purification, characterization, and applications of lipases. Biotechnology advances, 19(8):627662.

Sheehan, D. (2009). Physical Biochemistry: Principles and Applications. John Wiley \& Sons.

Shindo, H. \& Caldwell, J. (2004). Development of chiral drugs in japan: an update on regulatory and industrial opinion. Chirality, 7(5):349-352. 
Singaram, B. \& Goralski, C. (1998). The reduction of imines and enamines with transition metal hydrides. Transition Metals for Organic Synthesis, pages 147-154.

Singh, S., Kumar, T., Chandrasekharam, M., Giribabu, L., \& Reddy, P. (2009). Microwave-assisted, rapid, solvent-free aza-michael reaction by perchloric acid impregnated on silica gel. Synthetic Communications®, 39(22):39823989.

Skupinska, K., McEachern, E., Baird, I., Skerlj, R., \& Bridger, G. (2003). Enzymatic resolution of bicyclic 1-heteroarylamines using candida antarctica lipase b. The Journal of organic chemistry, 68(9):3546-3551.

Souza, R., Matos, L., Gonçalves, K., Costa, I., Babics, I., Leite, S., Oestreicher, E., \& Antunes, O. (2009). Michael additions of primary and secondary amines to acrylonitrile catalyzed by lipases. Tetrahedron Letters, 50(17):20172018.

Speicher, M., Antonarakis, S., \& Motulsky, A. (2010). Vogel and Motulsky's Human Genetics: Problems and Approaches. Human Genetics: Problems \& Approaches. Springer.

Studier, F. \& Moffatt, B. (1986). Use of bacteriophage 77 rna polymerase to direct selective high-level expression of cloned genes. Journal of molecular biology, 189(1):113.

Swietnicki, W. (2006). Folding aggregated proteins into functionally active forms. Current opinion in biotechnology, 17(4):367-372.

Tararov, V. \& Boerner, A. (2005). Approaching highly enantioselective reductive amination. ChemInform, 36(24).

Toda, F. (2005). Enantiomer Separation: Fundamentals and Practical Methods. Subcellular Biochemistry Series. Springer.

Torre, O., Alfonso, I., \& Gotor, V. (2004). Lipase catalysed michael addition of secondary amines to acrylonitrile. Chemical communications, (15):17241725 .

University, F. S. (2012). Dna sequencing facility. Disponível em: <http:// www.bio.fsu.edu/dna_sequencing-primerdesign.php>. Acesso em: 12 novembro 2012.

van Pelt-Verkuil, E., van Belkum, A., \& Hays, J. (2008). Principles and Technical Aspects of PCR Amplification. Springer. 
Verzijl, G., de Vries, J., \& Broxterman, Q. (2005). Removal of the acyl donor residue allows the use of simple alkyl esters as acyl donors for the dynamic kinetic resolution of secondary alcohols. Tetrahedron: asymmetry, 16(9):1603-1610.

Wikipedia (2012). Chiral lewis acid. Disponivel em: <http://en.wikipedia. org/wiki/Chiral_Lewis_acid>. Acesso em: 12 novembro 2012.

Xu, J., Zhang, F., Wu, Q., Zhang, Q., \& Lin, X. (2007). Hydrolase-catalyzed michael addition of 1,3-dicarbonyl compounds to $\alpha, \beta$-unsaturated compounds in organic solvent. Journal of Molecular Catalysis B: Enzymatic, 49(1):50-54.

Yadav, G. \& Borkar, I. (2008). Kinetic and mechanistic investigation of microwave-assisted lipase catalyzed synthesis of citronellyl acetate. Industrial \& Engineering Chemistry Research, 48(17):7915-7922.

Yamamoto, K., Nishioka, T., Oda, J., \& Yamamoto, Y. (1988). Asymmetric ring opening of cyclic acid anhydrides with lipase in organic solvents. Tetrahedron letters, 29(14):1717-1720.

Zaks, A. \& Klibanov, A. (1988). The effect of water on enzyme action in organic media. Journal of Biological Chemistry, 263(17):8017-8021. 